SIMONE CRISTINA BORGES BANDEIRA

\title{
IDENTIFICAÇÃO FUNCIONAL E ESTRUTURA GENÔMICA DE GENES NUCLEARES ASSOCIADOS À ATIVIDADE DA CITOCROMO C OXIDASE DE Paracoccidioides brasiliensis
}

Tese de doutorado apresentada ao Instituto De Ciências Biomédicas da Universidade de São Paulo, para obtenção do Título de Doutor em Ciências (Microbiologia).

São Paulo 


\section{SIMONE CRISTINA BORGES BANDEIRA}

\section{IDENTIFICAÇÃO FUNCIONAL E ESTRUTURA GENÔMICA DE GENES NUCLEARES ASSOCIADOS À ATIVIDADE DA CITOCROMO C OXIDASE DE Paracoccidioides brasiliensis}

Tese de doutorado apresentada ao Instituto De Ciências Biomédicas da Universidade de São Paulo, para obtenção do Título de Doutor em Ciências.

Área de concentração: Microbiologia

Orientadora: Profa. Marina Pasetto Nóbrega

São Paulo 
DADOS DE CATALOGAÇÃO NA PUBLICAÇÃO (CIP)

Serviço de Biblioteca e Informação Biomédica do

Instituto de Ciências Biomédicas da Universidade de São Paulo

(C) reprodução total

Bandeira, Simone Cristina Borges.

Identificação funcional e estrutura genômica de genes nucleares associados à atividade da citocromo e oxidase de Paracoccidioides brasiliensis / Simone Cristina Borges Bandeira. -- São Paulo, 2009.

Orientador: Maria Pasetto Nóbrega.

Tese (Doutorado) - Universidade de São Paulo. Instituto de Ciências Biomédicas. Departamento de Microbiologia. Área de concentração: Microbiologia. Linha de pesquisa: Genética Molecular e Genomas.

Versão do título para o inglês: Functional identification and genomic structure of Paracoccidioides brasiliensis nuclear genes associated to cytochrome oxidase activity.

Descritores: 1. Microbiologia 2. Fungos 3. Saccharomyces 4. Respiração celular 5. Genética Molecular 6. Paracoccidioides I. Nóbrega, Marina Pasetto II. Universidade de São Paulo. Instituto de Ciências Biomédicas. Programa de Pós Graduação em Microbiologia III. Título. 


\section{UNIVERSIDADE DE SÃO PAULO \\ INSTITUTO DE CIÊNCIAS BIOMÉDICAS}

Candidato(a):

Simone Cristina Borges Bandeira.

Título da Tese:

Identificação funcional e estrutura genômica de genes nucleares associados à atividade da citocromo e oxidase de Paracoccidioides brasiliensis.

Orientador(a):

Maria Pasetto Nóbrega.

A Comissão Julgadora dos trabalhos de Defesa da Tese de Doutorado, em sessão pública realizada a ................., considerou

\section{( ) Aprovado(a) \\ ( ) Reprovado(a)}

\begin{tabular}{|c|c|}
\hline Examinador(a): & $\begin{array}{l}\text { Assinatura: } \\
\text { Nome: ........ } \\
\text { Instituição: }\end{array}$ \\
\hline Examinador(a): & $\begin{array}{l}\text { Assinatura: } \\
\text { Nome: ........ } \\
\text { Instituição: }\end{array}$ \\
\hline Examinador(a): & $\begin{array}{l}\text { Assinatura: } \\
\text { Nome: ........ } \\
\text { Instituição: }\end{array}$ \\
\hline Examinador(a): & $\begin{array}{l}\text { Assinatura: } \\
\text { Nome: ........ } \\
\text { Instituição: }\end{array}$ \\
\hline Presidente: & $\begin{array}{l}\text { Assinatura: } \\
\text { Nome: ........ } \\
\text { Instituição: }\end{array}$ \\
\hline
\end{tabular}




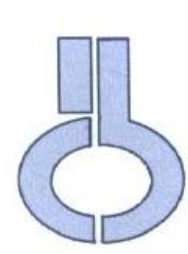

\section{CERTIFICADO DE ISENÇÃO}

Certificamos que o Protocolo CEP-ICB $\mathrm{N}^{\circ}$ 072, referente ao projeto intitulado "Identificação funcional e estrutura genômica de 20 genes nucleares associados a atividade da citocromo oxidase em paracoccidioides brasiliensis " sob a responsabilidade de Simone Cristina Borges Bandeira, foi analisado na presente data pela CEEA - COMISSÃO DE ÉTICA EM EXPERIMENTAÇÃO ANIMAL e pela CEPSH - COMISSÃO DE ÉTICA EM PESQUISA COM SERES HUMANOS, tendo sido deliberado que o referido projeto não envolve manipulação animal ou humana que justifique uma aprovação quanto aos princípios éticos exigidos por ambas as Comissões.

São Paulo, 28 de setembro de 2004.

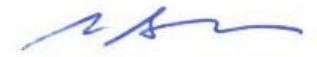

Profa. Dra. MARÍLIA C.L.SEELAENDER Coordenadora da CEEA - ICB/USP

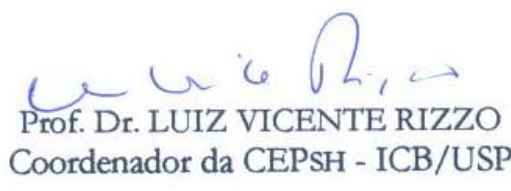




\section{AGRADECIMENTOS}

A todos que participaram dos projetos de sequenciamento de ESTs e RSTs do $P$. brasiliensis, portanto, agradeço a todos que de alguma forma contribuiram.

Agradeço a colaboração da Dra. Maria Sueli S. Felipe e do Dr. Gustavo Goldman pela disponobilização dos clones de ESTs com os quais trabalhei e apresento os resultados neste trabalho.

À Dra. Marina P. Nobrega pela orientação e pela confiança depositada em mim para a realização deste trabalho e também proporcionar as condções adequadas para a realização do mesmo.

Ao professor Dr. Francisco G. Nobrega pela valiosa contribuição, gentileza e disposição sempre que foi solicitado.

À Leila Maria Toffoli, Cynthia L. Le Bourlegat, Priscila M.S.M. Leite, Aline A. Guimara e Adolfo José Mota pelo suporte técnico no sequenciamento e pelo carinho dispensado às minhas amostras e por suas valiosas amizades.

À Dra. Márcia C. Sampaio, amiga e irmãzinha de todas as horas, por toda sua contribuição científica e pessoal que sem dúvidas foram e continuam sendo muito significantes.

À Dra. Cláudia Barbosa Ladeira de Campos, por toda sua contribuição, sem dúvidas fundamentais para a concretização de alguns resultados obtidos aqui e por toda amizade.

À Dra. Flavia V. Moraes, também pela contribuição e amizade.

Às amigas e colaboradoras Aline C. F. Barbosa, Ana Paula Santos e Carla S. Dias pela dedicação dispensadas na realização de parte das rotinas deste trabalho e também por suas amizades.

Aos todos os colegas do LGMG ( Mota, Sara, Priscila,que de alguma maneira deu a sua colaboração para a concretização deste trabalho, pricipalmente à Maria e Maria Alice que sempre estavam dispostas a colaborar.

Também gostaria de agradecer a nossa secretária da Pós-Graduação em

Microbiologia da USP, Alice Mitsue Shimabuku por toda delicadeza dispesada sempre que precisei de orientações.

Aos meus pais e ao meu namorado Werner, familiares e amigos que torcem muito por mim e sem dúvida foram a grande razão para nunca pensar em desistir.

A FAPESP e CNPq pelo apoio financeiro. 


\section{RESUMO}

Bandeira Simone Cristina Borges. Identificação funcional e estrutura genômica de genes nucleares associados à atividade da citocromo c oxidase de Paracoccidioides brasiliensis [Tese (Doutorado)]. São Paulo: Instituto de Ciências Biomédicas da Universidade de São Paulo; 2009.

O Paracoccidioides brasiliensis é um fungo patogênico, é o agente etiológico da paracoccidioidomicose, uma micose sistêmica prevalente na América Latina. $P$. brasiliensis é um fungo termodimórfico que vive na forma de micélio em temperatura ambiente $\left(\sim 25{ }^{\circ} \mathrm{C}\right)$ e sob a forma de levedura entre 35 e $37{ }^{\circ} \mathrm{C}$. Por comparação de seqüências e ensaios de complementação heteróloga em mutantes de $S$. cerevisiae identificamos e estudamos 15 novos genes de $P$. brasiliensis envolvidos na expressão do complexo da citocromo c oxidase mitocondrial (COX). Os genes PbCOX6, PbCOX17, PbCOX19 e PbOXA1 são capazes de substituir a função de seus homólogos nos respectivos mutantes de $S$. cerevisiae. Os genes analisados são modulados durante o processo de transição morfológica tanto de micélio para levedura quanto de levedura para micélio evidenciando a importância dos genes relacionados á respiração celular para o estabelecimento da patogenicidade do fungo. Acessamos a estrutura genômica dos genes identificados verificando a presença de introns e evidência de processamento alternativo dos genes. Além da função respiratória os genes COX11 e SCO1 de S. cerevisiae estão relacionados à função de resistência ao peróxido de hidrogênio e os homólogos de $P$. brasiliensis embora não sejam capazes de complementar funcionalmente a deficiência respiratória são equivalentes aos genes $C O X 11$ e SCO1 de $S$. cerevisiae na função quanto à resistência ao peróxido. Mostramos que os mutantes Cox17, Cox19 e Cox23 de $S$. cerevisiae também são em diferentes níveis, sensíveis a peróxido de hidrogênio e que os homólogos de $P$. brasiliensis PbCOX19 e PbCOX17 também são capazes de substituir esta função em $S$. cerevisiae. Demonstramos que em $P$. brasiliensis ocorre a produção de compostos bioativos sideróferos, sendo detectado sua secreção em meio de cultura sólido e líquido.

Palavras-chave: Paracoccidioides brasiliensis. Citocromo c Oxidase. Fungos. Saccharomyces cerevisiae. Respiração mitocondrial. Siderófero. 


\begin{abstract}
Bandeira Simone Cristina Borges. Functional identification and genomic structure of Paracoccidioides brasiliensis nuclear genes associated to cytochrome c oxidase activity [Ph.D. Thesis]. São Paulo: Instituto de Ciências Biomédicas da Universidade de São Paulo; 2009.

Paracoccidioides brasiliensis is a pathogenic fungus, the aethologic agent of the paracoccioidomycose, a systemic mycose prevalent in Lantin American. P. brasiliensis is a thermodimorphic fungus which lives in the mycelium form at room teperature $\left(\sim 25^{\circ} \mathrm{C}\right)$ and in the yeast form between $35^{\circ} \mathrm{C}$ e $37^{\circ} \mathrm{C}$. By sequence comparisson and heterologous functional complementation assays in $S$. cerevisiae we were able to identify and study fifteen (15) new $P$. brasiliensis genes involved in the mitochondrial cytochrome c oxidase expression (COX). Of which, PbCOX6, PbCOX17, PbCOX19 e PbOXA1genes were able to fuctionally replace its homogues in the $S$. cerevisiae null mutant. All $P$. brasiliensis genes analysed have their expression modulated during the morphologic transition from mycelium to yeast as well as from yeast to mycelium. This observation highlighted the importance of the respiration related genes in the fungus pathogenicity stablishment. Genomic structure of the identified genes were acessed confirming introns presence as wel as envidenced the alternative splicing occurrence. Besides respiration function, COX11 and SCO1 genes from S. cerevisiae were related to be involved in the hydrogen peroxide resistence and although $P$. brasiliensis homologues genes are not able to functionally replace its homologues in the respiratory deficiency they are able to restore the resistence to hydrogen peroxide in the $S$. cerevisiae null mutant strains. We showed that Cox17, Cox19 and Cox23 S. cerevisiae mutants are also, at different levels, sensitive to hydrogen peroxide and that $P$. brasiliensis homologues PbCOX17 and PbCOX19 are also able to replace this function in $S$. cerevisiae. It was demonstrated that there is bioactive compounds siderofore production in the fungus $P$. brasiliensis, and it was detected siderofore secretion in the solid and liquid culture medium.
\end{abstract}

Key words: Paracoccidioides brasiliensis. Cytochrome c Oxidase. Fungi. Saccharomyces cerevisiae. Mitochondrial Respiration. Siderofore. 


\section{SUMÁRIO}

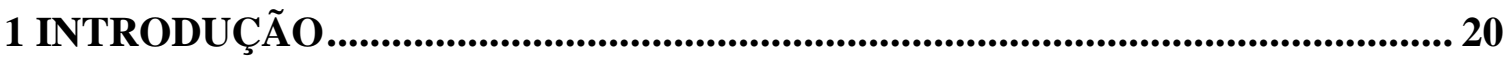

1.1 A Respiração Celular e o Complexo da Citocromo c Oxidase.......................... 20

1.2 Genes Envolvidos Na Montagem Do Complexo Da Citocromo C Oxidase

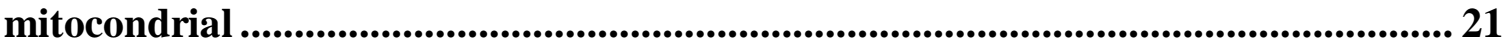

1.3 O Fungo Paracoccidioides brasiliensis ....................................................... 24

1.4 A Paracoccidioidomicose............................................................................ 25

1.5 Sequenciamento De ESTs De Paracocidioides brasiliensis ................................. 27

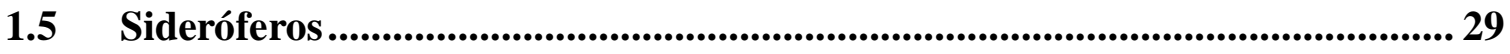

1.7 A Biosintese De Sideróferos .................................................................................. 30

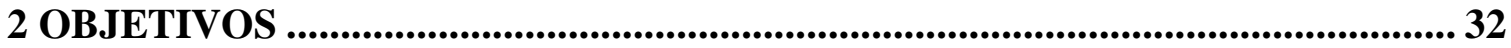

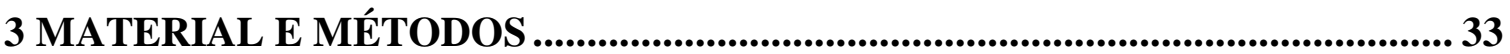

3.1 Linhagens De Leveduras E Bactérias.......................................................................... 33

3.2 Meios De Cultura Para Bactéria.............................................................................. 35

3.3 Meio de Cultura para Levedura ........................................................................ 35

3.4 Oligo-Inicidores Utilizados Para Seqüenciamento................................................. 35

3.5 Reação de PCR (Reação em Cadeia de Polimerase) de Seqüenciamento ........... 36

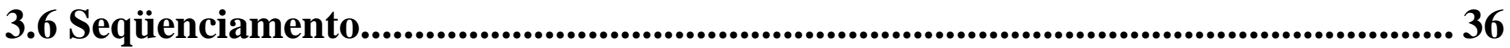

3.6.1 Análise dos Cromatogramas de Seqüenciamento ............................................ 37

3.7 Identificação da Fase Aberta de Leitura (“ORF - Open Reading Frame”)........ 37

3.8 Análises das Seqüências das Proteínas de Paracoccidioides brasiliensis.............. 37

3.9 Excisão das ORFs................................................................................................. 38

3.10 Preparação do Vetor de Expressão................................................................... 38

3.11 Ligação do Fragmento de DNA ao vetor .......................................................... 39

3.12 Reação de Inserção de Transposon.................................................................... 39

3.13 Preparo de Célula Competente de E.coli pelo método químico......................... 39

3.14 Transformação Bacteriana por choque térmico .................................................. 40

3.15 Extração de pDNA de Bactéria [método alcalino] ................................................ 40

3.16 Gel de Agarose para Eletroforese ............................................................................. 41

3.17 Transformação de Levedura pelo método de LiOAc........................................ 41

3.18 Extração de pDNA de Levedura [modificado por Alex Tzagoloff Columbia

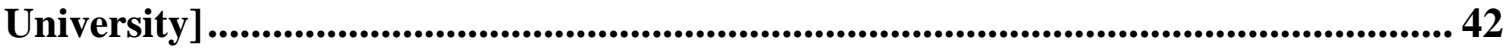


3.19 Extração de RNA total de Paracoccidioides brasiliensis [método adaptado por

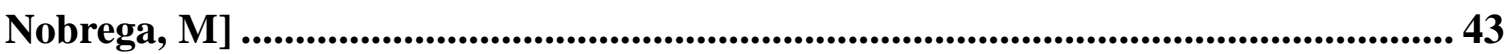

3.20 Reação de PCR em tempo real (RT-qPCR) ....................................................... 43

3.20.2 Lista de Oligos iniciadores Utilizados Nos Experimentos de PCR em Tempo Real (Real Time - RTqPCR) pela Tecnologia SYBR Green.................................... 46

3.21 Síntese de cDNA POLI(T) Para Clonagem do mRNA de Gene PbSCO1 ......... 49

3.22 Hibridização em Membrana ....................................................................... 49

3.23 Extração Alcalina do DNA fosmidial (pCC1DNA) [adaptado por Nóbrega M]50 3.24 Quebra do DNA fosmidial (pCC1DNA) por Nebulização [adaptado Nóbrega M]

3.25 Construção de Biblioteca de DNA fosmidial (pCC1DNA) em Vetor de clonagem pUC18 [Nobrega M et al.].............................................................................................. 52

3.26 Ensaio de Sensibilidade ao Peróxido de Hidrogênio [adaptado por Bandeira S]

3.27 Meio Sólido Para Detecção De Siderófero Em Paracoccidioides brasiliensis [adaptado por Bandeira S] 53

3.28 Meio Líquido Para Deteç̧ão De Siderófero Em Paracoccidioides brasiliensis [adaptado por Bandeira S] ................................................................................................ 53

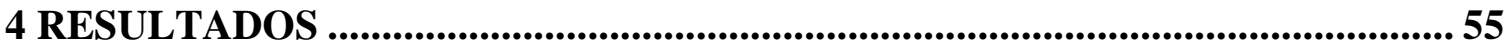

4.1 Estudo dos Genes de P. brasiliensis ......................................................................... 57

4.2 Resistência à Peróxido de Oxigênio (H2O2)..................................................... 122

4.4 Expressão Relativa De Genes Nucleares De $P$. brasiliensis Durante O Período De Transição Morfológica Induzida Pela Mudança Da Temperatura ........................... 138

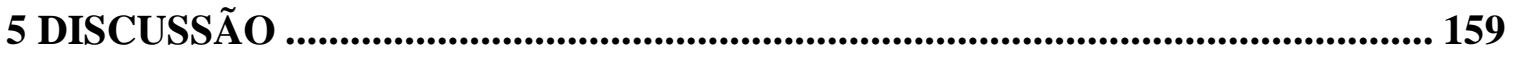

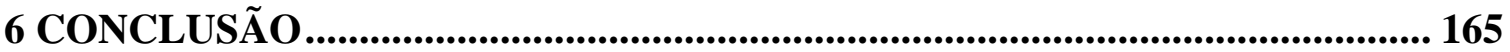

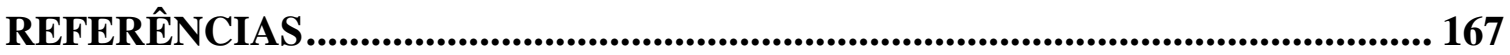




\section{LISTA DE TABELAS}

TABELA 1: Cepas de Escherichia coli

TABELA 2: Linhagens De Saccharomyces cerevisiae

TABELA 3: Lista de Primers e Probes para PCR em Tempo Real (RTqPCR) pela Tecnologia TaqMan 45

TABELA 4: Genes de P. brasiliensis Completos com Seqüências Depositadas No GenBank/NCBI

TABELA 5: Distribuição de íntrons dos genes estudados no isolados Pb01, Pb03 e Pb18 de $P$. brasiliensis. 


\section{LISTA DE FIGURAS}

FIGURA 1: Alinhamento da PbCox5Ap de P. brasiliensis $(\mathrm{Pb})$ com as proteínas homólogas. ................................................................................................ 59

FIGURA 2: Vetores de expressão em Saccharomyces cerevisiae. 60

FIGURA 3: Análise de resíduos característicos de hélices de transmembrana na PbCox5Ap.

FIGURA 4: Complementação funcional heteróloga do gene PbCOX6 no mutante de

S. cerevisiae.

FIGURA 5: Alinhamento da PbCox6p de P. brasiliensis $(\mathrm{Pb})$ com as proteínas homólogas.

FIGURA 6: Análise de resíduos característicos de hélices de transmembrana na PbCox6p.

FIGURA 7: Análise da seqüência consenso da RST-VP1-Pb30003-012G11. 66

FIGURA 8: Análise de resíduos característicos de hélices de transmembrana na PbCox8p.

FIGURA 9: Múltiplo alinhamento das seqüências das proteínas Cox8p de do isolado Pb18 com as homólogas.

FIGURA 10: Análise da seqüência consenso da RST-RC2-Pb30004-018D01. 70

FIGURA 11: Análise de resíduos característicos de hélices de transmembrana na PbCox11p.

FIGURA 12: Alinhamento da $P$ bCox11p de $P$. brasiliensis (Pb) com as proteínas homólogas

FIGURA 13: Alinhamento da $P$ bCox13p de $P$. brasiliensis $(\mathrm{Pb})$ com as proteínas homólogas

FIGURA 14A: Análise de resíduos característicos de hélices de transmembrana na PbCox13p.

FIGURA 15: Alinhamento da $P$ bCox15p de $P$. brasiliensis $(\mathrm{Pb})$ com as proteínas homólogas.

FIGURA 16A: Análise de resíduos característicos de hélices transmembrana na PbCox15p

FIGURA 17- Complementação Funcional da PbCox17p.

FIGURA 18: Alinhamento da $P$ bCox17p de $P$. brasiliensis $(\mathrm{Pb})$ com as proteínas homólogas.

FIGURA 19: Complementação Funcional da $P b C o x 19 p$.

FIGURA 20: Alinhamento da PbCox19p de $P$. brasiliensis $(\mathrm{Pb})$ com as proteínas homólogas. 
FIGURA 21:Comparação entre a PbCox23p e a seqüência da proteína ScCox23... 89

FIGURA 22: Alinhamento da Cox23p de $P$. brasiliensis $(\mathrm{Pb})$ com as proteínas

homólogas.

FIGURA 23: Comparação das seqüências das ESTs RC2-Pb30001-125H07-Pb18 e

EST002126-Pb01.

FIGURA 24: Comparação das seqüências das ESTs RC2-Pb30001-125H07-Pb18 e EST002126-Pb01

FIGURA 25: Alinhamento das proteínas PbPet100 dos dois isolados (Pb01 e Pb18) de $P$. brasiliensis

FIGURA 26A: Análise de resíduos característicos de hélices transmembrana na PbPet100p.

FIGURA 27: Alinhamento por BLASTp da ORF referente a proteína Pet112p de $P$. brasiliensis.

FIGURA 28: Alinhamento da PbPet112p de $P$. brasiliensis $(\mathrm{Pb})$ com as proteínas homólogas (continua)

FIGURA 28: Alinhamento da PbPet112p de $P$. brasiliensis $(\mathrm{Pb})$ com as proteínas homólogas (continuação).

FIGURA 29: Análise da seqüência consenso do inserto da construção pMGL3/PbPET191.

FIGURA 30: Múltiplo alinhamento das seqüências das proteínas Pet191p de Paracoccidioides brasiliensis.

FIGURA 31: Alinhamento da Mss51p de $P$. brasiliensis $(\mathrm{Pb})$ com as proteínas homólogas

FIGURA 31: Alinhamento da Mss51p de $P$. brasiliensis $(\mathrm{Pb})$ com as proteínas homólogas

FIGURA 32: Comparação das ORFs do Clones EST003371, EST001174 e RSTVP1-Pb00003-038F06.

FIGURA 33: Análise da seqüência consenso do clone 5’RACE-PbSCO1.

FIGURA 34: Seqüência consenso da RST-VP1-Pb00003-038F06 do gene PbSCO1 de P. brasiliensis.

FIGURA 35: Análise de resíduos característicos de hélices transmembrana na PbSco1p.

FIGURA 36: Alinhamento da Sco1p de P. brasiliensis $(\mathrm{Pb})$ com as proteínas homólogas.

FIGURA 37: Alinhamento por BLASTp ORF dda proteína PbOxa1p.................. 116

FIGURA 38- Complementação funcional da proteína PbOxa1. 
FIGURA 39: Alinhamento da proteína Oxa1p de $P$. brasiliensis $(\mathrm{Pb})$ com as proteínas homólogas.

FIGURA 40A: Análise de resíduos característicos de hélices transmembrana na proteína Oxa1p de $S$. cerevisiae.

FIGURA 41A: Teste à sensibilidade por peróxido de hidrogênio

FIGURA 41B: Sensibilidade por peróxido de hidrogênio.

FIGURA 42: Hipersensibilidade do mutante $a W 303 \Delta s c o 1$ ao peróxido de hidrogênio.

FIGURA 43: Sensibilidade dos mutantes $a W 303 \Delta \operatorname{cox} 17$ e $a W 303 \Delta \operatorname{cox} 19$ e BY4741 $\triangle$ cox23.

FIGURA 44: A resistência ao peróxido de hidrogênio é restabelecida pelos homólogos de $P$. brasiliensis.

FIGURA 45: Fragmentos utilizados com sonda de hibridização.

FIGURA 46: A-L: Identificação dos clones da biblioteca genômica (Fosmid) de P.brasiliensis.

FIGURA 47: PbCox23p predita no genoma do isolado Pb18.

FIGURA 48: Expressão do gene $P b C O X 2$ durante a transição morfológica de $P$. brasiliensis.

FIGURA 49: Expressão do gene $P b C O X 4$ durante a transição morfológica de $P$. brasiliensis.

FIGURA 50: Expressão do gene $P b C O X 5 A$ durante a transição morfológica de $P$. brasiliensis.

FIGURA 51: Expressão do gene $P b C O X 6$ durante a transição morfológica de $P$. brasiliensis.

FIGURA 52: Expressão do gene $P b C O X 8$ durante a transição morfológica de $P$. brasiliensis.

FIGURA 53: Expressão do gene $P b C O X 9$ durante a transição morfológica de $P$. brasiliensis.

FIGURA 54: Expressão do gene PbCOX11 durante a transição morfológica de $P$. brasiliensis.

FIGURA 55: Expressão do gene $P b C O X 12$ durante a transição morfológica de $P$. brasiliensis.

FIGURA 56: Expressão do gene PbCOX13 durante a transição morfológica de $P$. brasiliensis.

FIGURA 57: Expressão do gene $P b C O X 15$ durante a transição morfológica de $P$. brasiliensis. 
FIGURA 58: Expressão do gene $P b C O X 16$ durante a transição morfológica de $P$. brasiliensis.

FIGURA 59: Expressão do gene PbCOX11 durante a transição morfológica de $P$. brasiliensis.

FIGURA 60: Expressão do gene PbCOX19 durante a transição morfológica de $P$. brasiliensis.

FIGURA 61: Expressão do gene $P b C O X 11$ durante a transição morfológica de $P$. brasiliensis.

FIGURA 62: Expressão do gene PbOXA1 durante a transição morfológica de $P$. brasiliensis.

FIGURA 63: Expressão do gene PbPET100 durante a transição morfológica de $P$. brasiliensis.

FIGURA 64: Expressão do gene PbPET112 durante a transição morfológica de $P$. brasiliensis.

FIGURA 65: Expressão do gene PbMSS51 durante a transição morfológica de $P$. brasiliensis.

FIGURA 66: Expressão do gene $P b S C O 1$ durante a transição morfológica de $P$. brasiliensis.

FIGURA 67: Expressão do gene $P b N D I 1$ durante a transição morfológica de $P$. brasiliensis.

FIGURA 68: Expressão do gene $P b R I P 1$ durante a transição morfológica de $P$. brasiliensis.

FIGURA 69: Expressão do gene $P b Q C R 7$ durante a transição morfológica de $P$. brasiliensis.

FIGURA 70: Expressão do gene $P b A T P 4$ durante a transição morfológica de $P$. brasiliensis.

FIGURA 71: Expressão do gene $P b A T P 7$ durante a transição morfológica de $P$. brasiliensis.

FIGURA 73: Detecção da produção de sideróferos em cinco isolados de $P$. brasiliensis.

FIGURA 74: Alinhamento por BLASTp da proteína L-ornithine-N5-oxygenase de P. brasiliensis. 


\section{LISTA DE ABREVIATURAS}

$\Delta$

$\rho^{-}$

$\rho^{0}$

$\mu \mathrm{g}$

$\mu \mathrm{L}$

"Null mutant"

aa.

$\AA$

ADP

ATP

ADH1

leveduras

$\mathrm{CaCl} 2$

cDNA

Chr

DMSO

DNA

dNTPs

EDTA

EG

EST

H2Odd

$\mathrm{HCl}$

hCOX16

Hsp

$\mathrm{Kb}$

LA

LB

M

$\mathrm{Mb}$

mg

$\mathrm{MgSO}_{4}$

$\mathrm{mL}$

$\mathrm{mM}$

mRNA

mtDNA

$\mathrm{NaCl}$

$\mathrm{NaOAc}$

$\mathrm{NaOH}$

NCBI

$\mathrm{NADH}$

$\mathrm{NH}_{4} \mathrm{OAc}$

ORF

$\mathrm{Pb}$

$\mathrm{pb}$

PbCOX 2

$\mathrm{PbCOX} 4$ deleção parcial ou total de um gene específico

linhagem de levedura como deleção parcial do mtDNA

linhagem de levedura como deleção total do mtDNA

micrograma

microlitro

mutante por deleção parcial ou total de um gene

aminoácidos

ângstrons $(0,1 \mathrm{mM})$

adenosina difosfato

adenosina trifosfato

Gene que codifica para a enzima álcool desidrogenase em

cloreto de cálcio

DNA complementar

cromossomo

dimetilsulfoxido

ácido desoxirribonucléico

deoxinucleotídeos trifosfatos para as quatro bases de DNA

ácido etilenodiamino tetracético

meio de cultura contendo etanol e glicerol como fontes de carbono

"Expressed Sequence Tag”

água destilada e deionizada

ácido clorídrico

Gene COX16 humano (Homo sapiens)

"Heat Shock Protein"

kilobase

meio de cultura de Luria e Bertani com Ampicilina

meio de cultura de Luria e Bertani

molar

Megabase

miligrama

sulfato de magnésio

mililitro

milimolar

RNA-mensageiro

DNA mitocondrial

cloreto de sódio

acetato de sódio

hidróxido de sódio

National Center for Biotechnology Information

Nicotinamida adenina dinucleotídeo

acetato de amônia

fase aberta de leitura ("open reading frame")

Paracoccidioides brasiliensis

pares de base

Gene COX2 de Paracoccidioides brasiliensis

Gene COX4 de Paracoccidioides brasiliensis 


\begin{tabular}{|c|c|}
\hline$P b \operatorname{Cox} 4 p$ & Proteína Cox4 de Paracoccidioides brasiliensis \\
\hline ScCOX4 & Gene COX4 de Saccharomyces cerevisae \\
\hline ScCox $4 p$ & Proteína Cox4 de Saccharomyces cerevisae \\
\hline$P b C O X 5 A$ & Gene COX5A de Paracoccidioides brasiliensis \\
\hline PbCox5p & Proteína Cox4A de Paracoccidioides brasiliensis \\
\hline ScCOX5A & Gene COX5A de Saccharomyces cerevisae \\
\hline ScCox5p & Proteína Cox4A de Saccharomyces cerevisae \\
\hline PbCOX6 & Gene COX6 de Paracoccidioides brasiliensis \\
\hline PbCox6p & Proteína Cox6 de Paracoccidioides brasiliensis \\
\hline ScCOX6 & Gene COX6 de Saccharomyces cerevisae \\
\hline ScСox6p & Proteína Cox6 de Saccharomyces cerevisae \\
\hline $\mathrm{PbCOX8}$ & Gene COX8 de Paracoccidioides brasiliensis \\
\hline PbCox8p & Proteína Cox8 de Paracoccidioides brasiliensis \\
\hline ScCOX8 & Gene COX8 de Saccharomyces cerevisae \\
\hline ScCox8p & Proteína Cox8 de Saccharomyces cerevisae \\
\hline PbCOX9 & Gene COX9 de Paracoccidioides brasiliensis \\
\hline PbCox9p & Proteína Cox9 de Paracoccidioides brasiliensis \\
\hline ScCOX9 & Gene COX9 de Saccharomyces cerevisae \\
\hline ScCox9p & Proteína Cox9 de Saccharomyces cerevisae \\
\hline PbCOX11 & Gene COX11 de Paracoccidioides brasiliensis \\
\hline PbCox11p & Proteína Cox11 de Paracoccidioides brasiliensis \\
\hline ScCOX11 & Gene COX11 de Saccharomyces cerevisae \\
\hline ScCox11p & Proteína Cox11 de Saccharomyces cerevisae \\
\hline $\operatorname{PbCOX12}$ & Gene COX12 de Paracoccidioides brasiliensis \\
\hline$P b C o x 12 p$ & Proteína Cox12 de Paracoccidioides brasiliensis \\
\hline ScCOX12 & Gene COX12 de Saccharomyces cerevisae \\
\hline ScCox $12 p$ & Proteína Cox12 de Saccharomyces cerevisae \\
\hline $\operatorname{PbCOX13}$ & Gene COX13 de Paracoccidioides brasiliensis \\
\hline$P b C o x 13 p$ & Proteína Cox13 de Paracoccidioides brasiliensis \\
\hline ScCOX13 & Gene COX13 de Saccharomyces cerevisae \\
\hline ScCox13p & Proteína Cox13 de Saccharomyces cerevisae \\
\hline $\operatorname{PbCOX15}$ & Gene COX15 de Paracoccidioides brasiliensis \\
\hline$P b C o x 15 p$ & Proteína Cox15 de Paracoccidioides brasiliensis \\
\hline ScCOX15 & Gene COX15 de Saccharomyces cerevisae \\
\hline ScCox15p & Proteína Cox15 de Saccharomyces cerevisae \\
\hline $\operatorname{PbCOX16}$ & Gene COX16 de Paracoccidioides brasiliensis \\
\hline$P b C o x 16 p$ & Proteína Cox16 de Paracoccidioides brasiliensis \\
\hline ScCOX16 & Gene COX16 de Saccharomyces cerevisae \\
\hline ScCox16p & Proteína Cox16 de Saccharomyces cerevisae \\
\hline $\operatorname{PbCOX17}$ & Gene COX17 de Paracoccidioides brasiliensis \\
\hline PbCox17p & Proteína Cox17 de Paracoccidioides brasiliensis \\
\hline ScCOX17 & Gene COX17 de Saccharomyces cerevisae \\
\hline ScCox $17 p$ & Proteína Cox17 de Saccharomyces cerevisae \\
\hline PbCOX19 & Gene COX19 de Paracoccidioides brasiliensis \\
\hline PbCox19p & Proteína Cox19 de Paracoccidioides brasiliensis \\
\hline ScCOX19 & Gene COX19 de Saccharomyces cerevisae \\
\hline ScCox19p & Proteína Cox19 de Saccharomyces cerevisae \\
\hline PbCOX23 & Gene COX23 de Paracoccidioides brasiliensis \\
\hline PbCox23p & Proteína Cox23 de Paracoccidioides brasiliensis \\
\hline ScCOX23 & Gene COX23 de Saccharomyces cerevisae \\
\hline
\end{tabular}




\begin{tabular}{|c|c|}
\hline ScCox23p & Proteína Cox23 de Saccharomyces cerevisae \\
\hline PbPET100 & Gene PET100 de Paracoccidioides brasiliensis \\
\hline PbPet100p & Proteína Pet100 de Paracoccidioides brasiliensis \\
\hline ScPET100 & Gene PET100 de Saccharomyces cerevisae \\
\hline ScPet100p & Proteína Pet100 de Saccharomyces cerevisae \\
\hline PbPET112 & Gene PET112 de Paracoccidioides brasiliensis \\
\hline PbPet112p & Proteína Pet112 de Paracoccidioides brasiliensis \\
\hline ScPET112 & Gene PET112 de Saccharomyces cerevisae \\
\hline ScPet112p & Proteína Pet112 de Saccharomyces cerevisae \\
\hline PbPET191 & Gene PET191 de Paracoccidioides brasiliensis \\
\hline PbPet191p & Proteína Pet191 de Paracoccidioides brasiliensis \\
\hline ScPET191 & Gene PET191 de Saccharomyces cerevisae \\
\hline ScPet191p & Proteína Pet191 de Saccharomyces cerevisae \\
\hline$P b O X A 1$ & Gene OXA1 de Paracoccidioides brasiliensis \\
\hline$P b O x a 1 p$ & Proteína Oxa1 de Paracoccidioides brasiliensis \\
\hline ScOXA1 & Gene OXA1 de Saccharomyces cerevisae \\
\hline ScOxa1p & Proteína Oxa1 de Saccharomyces cerevisae \\
\hline PbMSS51 & Gene MSS51 de Paracoccidioides brasiliensis \\
\hline PbMss51p & Proteína Mss51 de Paracoccidioides brasiliensis \\
\hline ScMSS51 & Gene MSS51 de Saccharomyces cerevisae \\
\hline ScMss51p & Proteína Mss51 de Saccharomyces cerevisae \\
\hline PbSCO1 & Gene SCO1 de Paracoccidioides brasiliensis \\
\hline PbSco1p & Proteína Sco1 de Paracoccidioides brasiliensis \\
\hline ScSCO1 & Gene SCO1 de Saccharomyces cerevisae \\
\hline ScSco1p & Proteína Sco1 de Saccharomyces cerevisae \\
\hline PbATP4 & Gene ATP4 de Paracoccidioides brasiliensis \\
\hline PbATP7 & Gene ATP7 de Paracoccidioides brasiliensis \\
\hline PbQCR7 & Gene QCR7 de Paracoccidioides brasiliensis \\
\hline PbRIP1 & Gene RIP1 de Paracoccidioides brasiliensis \\
\hline PbNDI1 & Gene NDI1 de Paracoccidioides brasiliensis \\
\hline PCR & reação de polimerização em cadeia da DNApolimerase \\
\hline pDNA & DNA plasmidial \\
\hline PEG & polietileno glicol \\
\hline PET & $\begin{array}{l}\text { Classe de genes nucleares de leveduras que condificam para } \\
\text { alguma das subunidades dos complexos da cadeia transportadora } \\
\text { de elétrons mitocondrial. }\end{array}$ \\
\hline Pet & $\begin{array}{l}\text { Mutantes de genes nucleares de leveduras que condificam para } \\
\text { alguma das subunidades dos complexos da cadeia transportadora } \\
\text { de elétrons mitocondrial. }\end{array}$ \\
\hline RNA & ácido ribonucléico \\
\hline rpm & rotações por minuto \\
\hline RST & “Random Sequence Tag” \\
\hline Sc & Saccharomyces cerevisiae \\
\hline SDS & dodecil sulfato de sódio \\
\hline TBE & Tampão de Tris borato EDTA \\
\hline $\mathrm{TE}$ & Tris-Cl e EDTA \\
\hline Tris & tris hidroximetil - aminometano \\
\hline UV & luz ultravioleta \\
\hline V & volts \\
\hline $\mathrm{v} / \mathrm{v}$ & volume/volume \\
\hline
\end{tabular}


$\mathrm{w} / \mathrm{v}$

WO

$\mathrm{X}$-gal

$\mathrm{LiOAc}$ peso/volume

meio mínimo para cultura seletiva de linhagem sem aminoácidos 5-Bromo-4-cloro-3-indolyl- $\beta$-D-galactopyranoside

Acetato de lítio 


\section{INTRODUÇÃO}

\subsection{A Respiração Celular e o Complexo da Citocromo c Oxidase}

Em eucariotos a produção da maior parte de energia consiste na oxidação de moléculas $\mathrm{NADH}$ e $\mathrm{FADH}_{2}$ geradas a partir das reações de metabolismo dos nutrientes ingeridos. A oxidação de $\mathrm{NADH}$ e $\mathrm{FADH}_{2}$ ocorre na cadeia transportadora de elétrons localizada na membrana interna da mitocôndria. A cadeia transportadora de elétrons mitocondrial é constituída por quatro complexos enzimáticos distintos, o complexo da NADH-Coenzima Q-redutase (complexo I), da Succinato-Coenzima Q redutase (complexo II), da ubiquinol citocromo c redutase (complexo III) e da citocromo c oxidase (complexo IV), além do complexo da ATP-sintase. Parte da energia gerada no processo de oxidação das moléculas de $\mathrm{NADH}$ e $\mathrm{FADH}_{2}$ é utilizada para o bombeamento de prótons $\left(\mathrm{H}^{+}\right)$da matriz mitocondrial para o espaço intermembranar durante a transferência de elétrons na cadeia respiratória. Através desses complexos, a mitocôndria exerce sua principal função que é a produção da energia utilizada pelas células via respiração aeróbica, processo este denominado fosforilação oxidativa (Hatefi, 1985).

A citocromo c oxidase é o complexo terminal da cadeia transportadora de elétrons em eucariotos. Este complexo que é formado por onze subunidades estruturais em S. cerevisiae, atua na transferência de elétrons do citocromo c para o oxigênio molecular reduzindo-o para a formação de moléculas de água. Esta função central na produção de energia celular faz da citocromo c oxidase um componente de fundamental importância para os organismos aeróbicos (Herrmann e Funes 2005).

Com a estrutura tridimensional de raios- $\mathrm{X}$ da citocromo c oxidase bovina definida ao nível de 2,8A de resolução por Tsukihara et al. em 1995 foi possível identificar os sítios de ligação dos metais que atuam como cofatores neste complexo, bem como as subunidades associadas a estes íons e o mecanismo de transporte dos elétrons. São encontrados dois centros detentores de íons cobre na citocromo c oxidase. Um na subunidade II, chamado centro binuclear $\mathrm{CuA}$, que requer dois átomos de cobre e é o primeiro aceptor de elétrons do citocromo c e o outro está associado à subunidade I, chamado centro de CuB.

Os elétrons provenientes do centro binuclear CuA são transferidos para o grupo heme do citocromo a, que então os entrega ao grupo heme do citocromo a3. Os elétrons do grupo heme a3 são doados ao centro de cobre $\mathrm{CuB}$ onde são utilizados na redução do oxigênio molecular para a formação da molécula de água (Michel et al., 1998; Tsukihara et al., 1996). 


\subsection{Genes Envolvidos Na Montagem Do Complexo Da Citocromo C Oxidase mitocondrial}

A biogênese do complexo da citocromo c oxidase mitocondrial é um dos processos mais elegantes e sofisticados já visto em biologia molecular. A complexidade reside no fato de que a expressão da citocromo c oxidase depende da expressão coordenada de genes nucleares e mitocondriais. A grande massa de conhecimentos obtidos sobre a biogênese deste complexo vem dos estudos em levedura Saccharomyces cerevisiae. Neste organismo este complexo é composto por onze subunidades estruturais. As três maiores subunidades (Cox1p, Cox2p e Cox3p) que formam o centro catalítico da enzima, são codificados pelo DNA mitocondrial (mtDNA) e processadas dentro da organela. As oito subunidades estruturais restantes são codificadas no genoma nuclear, traduzidas no citoplasma e importadas para a mitocôndria (Taanman e Capaldi, 1992; Glerum et al., 1995). Apenas duas das onze subunidades estruturais (Cox1p e Cox $2 p$ ) estão ligadas aos grupos prostéticos hemes a e heme a3 e aos centros de cobre $(\mathrm{CuA})$ e $(\mathrm{CuB})$ que participam da transferência de elétrons do citocromo c reduzido para a molécula de oxigênio (Tzagoloff et al., 1974). Outros íons como zinco, magnésio e sódio também são encontrados na citocromo c oxidase entretanto, ainda quase não existem dados sobre as funções destes íons no complexo.

Além das subunidades estruturais outras dezenas de produtos gênicos nucleares são necessárias para a biogênese funcional do complexo (McEwen et al., 1986; Tzagoloff et al., 1986; Tzagoloff e Dieckmann, 1990; Barrientos et al., 2002). Estas proteínas acessórias estão atuando na estabilização dos transcritos e das subunidades recém sintetizadas, regulação da expressão, integração na membrana interna mitocondrial e interações físicas entre as subunidades estruturais e com outros complexos (Herrmann e Funes 2005), muitas outras ainda são necessária para a entrega, formação e inserção dos cofatores como os íons metálicos.

Entre as subunidades nucleares estruturais do complexo da COX em S. cerevisiae está o gene COX4 que codifica para a subunidade IV (Poyton e Schatz, 1975; Maarse et al., 1984; Dowhan et al., 1985). Cox4p é essencial para o funcionamento do complexo desde que células mutantes não completam a montagem do complexo funcional. Esta proteína atua com ligante de zinco e é a única subunidade contendo cofator (está ligada a um único íon de Zn(II) através de quatro resíduos de cisteína) que não faz para do corpo catalítico da enzima. A 
função biológica na ligação de zinco com esta subunidade do complexo da COX ainda não foi elucidada (Coyne 3rd et al., 2007).

O gene COX5A (Waterland et al., 1991; Koemer et al., 1985) e o gene COX5B que codificam para duas formas distintas de subunidade $\mathrm{V}$ de citocromo c oxidase, as subunidades Cox5a e Cox5b, respectivamente. O nível da taxa de respiração em células carregando alelos nulos de $\operatorname{cox} 5 \boldsymbol{a}$ ou $\operatorname{cox} 5 \boldsymbol{b}$ ou ambos indica que de alguma forma a subunidade $\mathrm{V}$ é necessária para a atividade citocromo c oxidase e que a função de Cox5a é muito mais eficaz do que Cox5b (Trueblood e Poyton, 1987).

O gene COX6 para a subunidade VI (Wright et al., 1984; Wright et al., 1989; Grant et al., 1997), COX13 para a subunidade VIa (Taanman e Capaldi, 1993; Beauvoit et al., 1999) e COX12 para a subunidade VIb (Lamarche et al., 1992). O gene $\boldsymbol{C O X 7}$ codificando para a subunidade VII (Aggeler e Capaldi, 1990; Nobrega et al., 1998) e o gene COX9 para a subunidade VIIa (Wright et al., 1986) e o gene COX8 que codifica para a subunidade VIII (Patterson e Poyton, 1986).

Entre as proteínas acessórias codificadas pelos genes nucleares, que atuam na montagem do complexo da citocromo c oxidase funcional está a Cox10p que é uma farnesiltransferase que adiciona o radical farnesil ao grupo prostético heme A (Nobrega, 1990; Glerum e Tzagoloff et al., 1994). A Cox11p que insere os íons de cobre (CuB) e magnésio durante a montagem do complexo da COX (Tzagoloff et al., 1990; Tzagoloff et al., 1993, Pungartnik et al., 1999). A Cox14p que foi recentemente identificada e caracterizada (Glerum et al., 1995) tendo sido comprovado a sua interação com a proteína Mss51p para garantir a estabilidade da proteína Cox1p (Barrientos et al., 2004). A Cox15p que faz a hidroxilação do grupo prostético heme $\mathrm{O}$, uma etapa intermediária na via de síntese do heme A (Glerum et al., 1997; Barros et al., 2002). A Cox16p (Carlson et al., 2003) com função ainda não definida.

Já a gene Cox17p é uma metalchaperona envolvida no transporte de íons $\mathrm{Cu}$ para dentro da mitocôndria (Glerum et al., 1996; Beers et al., 1997; Amaravadi et al., 1997; Maxfield et al., 2004). A proteína Cox18p que interage com as proteínas Pnt1p (He e Fox, 1999; Souza et al., 2000; Saracco e Fox, 2002; Ludewig e Staben, 1994) e Mss2p (Simon et al., 1995; Saracco e Fox, 2002; Broadley et al., 2001) para exportar a porção carboxi terminal da subunidade Cox2p da matriz mitocondrial para o espaço intermembranar (Souza et al., 2000; Saracco et Fox. 2002). Também já identificada e caracterizada a proteína Cox19p (Nobrega, M et al., 2002) que apresenta consistente evidencias de ser homóloga a proteína Cox17p. A Cox20p uma chaperona específica que atua no processamento e montagem da subunidade Cox2p no complexo da citocromo c oxidase (Hell et al., 2000). A Cox23p (Barros 
et al., 2004) também homóloga da $\operatorname{Cox17p}$ (Barros et al., 2004). A proteína Cox24p atuando no processamento do gene COX1 (Barros et al., 2006). A proteina Mrs1p ou Pet157p (Johnson e McEwen, 1997) também envolvida no processamento de introns do gene COX1 e neste processo tem se conhecimento do envolvimento do produto de mais três genes nucleares PET54 (Costanzo et al., 1986a; Costanzo et al., 1989; Valencik et al., 1989), SUV3 ou LPB2 (Conrad-Webb et al., 1990) e MSS18 (Seraphin et al., 1988). A Mss1p ou Pet53 que é uma GTPase que também age no processamento dos introns do gene COX1 (Decoster et al.,1993; Colby et al., 1998). Enquanto a proteína Mrs2p atua no transporte de magnésio para mitocôndria similar ao gene CorA de bactéria e também é essencial no processamento de introns mitocondriais (Weisenberger et al.,1992; Zsurka et al., 2001). A proteína Mss51p que é uma proteína requerida para a regulação da expressão, tradução e maturação do mRNA do gene COX1. Além de promover a síntese da proteína Cox1p mitocondrial, a proteína Mss51p também interage com a subunidade recém sintetizada (Decoster et al., 1990; Faye e Simon, 1983; Barrientos et al., 2002; Perez-Martinez et al., 2003; Barrientos et al., 2004). A proteína Mss116p, uma helicase envolvida no processamento de introns dos genes apocitocromo b e COX1 (Niemer et al., 1995; Minczuk et al., 2002). Já a NamIp ou Mtf2p está envolvida no processamento dos mRNAs dos genes COB/COX1 e ATP6 (Rodeheffer eta la 2001,Bryan et al., 2002,Rodeheffer eta al 2003) e a proteína Nam2p que é uma Leucina tRNA sintetase mitocondrial com função diretamente relacionada ao processamento de introns mitocondriais do grupo I sendo portanto, indiretamente requerida para a estabilidade do genoma mitocondrial (Rho e Martinis, S.A., 2000; Herbert et al., 1988a; 1988b). A proteína Oxa1p, uma insertase que atua na exportação de proteínas da matriz para a membrana interna mitocondrial e para o espaço intermembranar (Bonnefoy et al., 1994a; Bonnefoy et al., 1994b; He e Fox, 1997; Sylvestre et al., 2003). A proteína Pet100p que é uma chaperonina que faz a inserção do subcomplexo Cox7p-Cox8p-Cox9p na holoenzima COX (Church et al., 1996; Forsha et al., 2001; Church et al., 2005). A proteína Pet111p atua como ativador específico de expressão da $\operatorname{Cox} 2 \boldsymbol{p}$ (Poutre e Fox, 1987; Green-Willms et al., 2001; Naithani et al., 2003). A Pet112p envolvida na expressão de genes mitocondriais e é também é fundamental na expressão da proteína Cox2p (Mulero et al., 1994). Já as proteína Pet122p (Ohmen et al., 1988; Marathe et al., 1999; Costanzo e Fox, 1988; Naithani et al., 2003) e Pet494p (Muller e Fox, 1984; Costanzo et al., 1986b; Naithani et al., 2003) agem como ativadores traducionais do gene COX3. As proteínas Pet117p e Pet191p, que são requeridas na montagem da citocromo c oxidase ativa, porém as funções específicas ainda não foram elucidadas (McEwen et al., 1993). A Pet309p que é uma proteína integral da membrana interna mitocondrial que 
também é requerida para a expressão da $\operatorname{Cox1p}$ (Manthey e McEwen, 1995; Manthey et al., 1998; Naithani et al., 2003) assim como a proteína Shy1p (Mashkevich et al., 1997; Barrientos et al., 2002). A proteína Sco1p ou Pet161 envolvida no transporte de íons Cu para a COX e que também garante a estabilidade das subunidades Cox1p e Cox2p (Schulze e Rodel, 1988, 1989; Beers et al., 2002; Paret et al., 1999). A Sco1p é homologa da proteína Sco2p codificada pelo gene SCO2 que inicialmente foi identificado como um supressor de múltipla cópia de mutantes deficientes respiratórios devido à inatividade de SCO1 (Lode et al., 2002; Maxfield et al., 2004).

Embora muito se saiba sobre os genes envolvidos para manter o complexo citocromo oxidase funcional ainda serão necessários muitos estudos sobre vários destes genes acima descritos, quanto a suas funções especificas e neste processo vários outros novos genes ainda poderão surgir. Um dos principais focos de estudos hoje é como ocorre o controle da expressão dos genes entre organelas distintas (núcleo e mitocôndria) envolvidas numa síntese tão complexa como esta do complexo da citocromo c oxidase mitocondrial.

\subsection{O Fungo Paracoccidioides brasiliensis}

O Paracoccidioides brasiliensis é um fungo termo-dimórfico apresentando-se como micélio em temperatura ambiente $\left(\sim 25^{\circ} \mathrm{C}\right)$ e sob a forma de levedura entre 35 e $37^{\circ} \mathrm{C}$. Este fungo foi observado pela primeira vez em 1908 por Adolfo Lutz. O fungo apresentando um formato celular arredondado se reproduzia por brotamento em cortes de tecidos de pacientes com intensas lesões orofaringeanas. Após o isolamento do fungo Lutz também observou seu crescimento na forma filamentosa em vários meios de cultura à temperatura ambiente $\left(25^{\circ} \mathrm{C}\right)$. Devido a essa natureza dimórfica, Lutz atribuiu o termo Hifoblastomicose para doenças que fossem causadas por este microorganismo. Uma descrição mais detalhada deste fungo e das particularidades clínicas histopatológicas dessa doença foi realizada por Afonso Splendore entre 1909 e 1912, a partir de então o fungo ficou conhecido como uma levedura ascomicotina a qual Splendore chamou de Zymonema brasiliensis. Duas décadas depois, Floriano Paulo de Almeida caracterizou mais detalhadamente a doença Paracoccidioidomicose (PCM) bem com o seu agente etiológico conhecido hoje como Paracoccidioides brasiliensis (Lacaz et al., 1991).

Atualmente o Paracoccidioides brasiliensis é classificado como um eucarioto pertencente ao reino Fungi, ao filo Ascomycota, subfilo Pezizomycotina, a classe 
Eurotiomycetes, da ordem Onygenales, família Onygenales mitospórico, do gênero Paracoccidioides e da espécie Paracoccidioides brasiliensis (NCBI-GeneBank 121759).

Embora ainda não esteja claramente definido seu habitat natural, acredita-se que o $P$. brasiliensis viva em solos úmidos cobertos por vegetais e ricos em proteínas, cuja temperatura varia de 11 a $30{ }^{\circ} \mathrm{C}$, não ocorrendo na bacia amazônica. O fungo já foi isolado de solo, de cascas de árvores, fezes de morcegos e parasitando tatu (Restrepo, 1985).

Estudos citológicos de marcação fluorescente nuclear indicaram que o genoma deste fungo varia de aproximadamente 23 a $30 \mathrm{Mb}$ e análises do cariótipo por eletroforese sugerem que ele seja constituído por quatro (04) a cinco (05) cromossomos com tamanhos variando entre 2 a 10Mb (Cano et al., 1998; Montoya et al., 1999). Estudos de cariótipo de uma coleção de doze (12) isolados clínicos sugerem que existe isolados haplóides, diplóide (ou aneuploides), multinucleado e com indicação de polimorfismo entre os isolados (Montoya et al., 1999; Feitosa et al., 2003).

\subsection{A Paracoccidioidomicose}

A contaminação com o P. brasiliensis ocorre pela inalação de conídios miceliais encontrados no ambiente e o estabelecimento da doença ocorre quando o fungo se aloja nos pulmões e em temperatura corpórea $\left(37^{\circ} \mathrm{C}\right)$ inicia a transição de micélio para a forma patogênica de levedura (McEwen et al., 1987).

A Paracoccidioidomicose (PCM) é a doença sistêmica crônica restrita à América Latina entretanto, devido aos fluxos migratórios estão sendo encontrados casos em outros continentes (Restrepo e Moreno, 1993). O Brasil, a Argentina, a Venezuela são considerados como áreas endêmicas da PCM sendo que a maior incidência é em trabalhadores rurais do sexo masculino com faixa etária entre 30 e 60 anos. Restrepo (1985) observou através de estudos epidemiológicos que a PCM é encontrada em regiões que possuem invernos curtos e verões chuvosos. A PCM é classificada em duas formas clínicas: 1) Crônica ou do “Tipo Adulto”, produz manifestações que variam muito, mas geralmente os pulmões são mais afetados, sendo que a boca freqüentemente apresenta lesões. 2) Aguda ou do “Tipo Juvenil”, com manifestações clínicas mais grave, aparecendo apenas em 4\% dos casos, afetando crianças de ambos sexos.

A PCM é uma das mais importantes micoses na América Latina. Aproximadamente dez milhões de pessoas estão infectadas sendo que destas, $2 \%$ poderão desenvolver a doença (McEwen et al., 1995). Esta micose tem ganhado maior importância desde que foi reportada 
entre pacientes com AIDS na América Latina (Goldani et al., 1995). Os principais fatores para o estabelecimento da PCM parecem estar ligados à idade, o estado emocional, o patrimônio genético e a integridade da reposta imunológica, além das características de virulência da cepa infectante. A patogenicidade da cepa infectante parece estar intimamente ligada à transição morfológica, desde que linhagens do fungo que são incapazes de se transformarem em levedura não são virulentas (Borges-Walmsley et al., 2002; Medoff et al., 1987; Rooney; Klein, 2002; San-Blas e Ninõ-Vega, 2001). A Transição morfológica do P. brasiliensis em contraste a outros fungos dimórficos que depende de estímulos complexos, como por exemplo em C.albicans (Enerst, 2000), pode ser induzida simplesmente por aumento da temperatura de incubação da cultura de $25{ }^{\circ} \mathrm{C}$ para $37{ }^{\circ} \mathrm{C}$, o que destaca este fungo como um excelente modelo para o estudo dos processos fisiológicos que levam à transição dimórfica. Estudos anteriores (Medoff et al., 1987) sugerem que durante a transição morfológica ocorrem alterações fisiológicas mitocondriais como o desacoplamento parcial ou completo da fosforilação oxidativa, ausência ou baixo consumo de oxigênio e inibição da síntese de RNA e proteínas. Entretanto estes estudos não esclarecem se as alterações fisiológicas mitocondriais ocorrem como um efeito ao aumento da temperatura e da transição morfológica ou seriam estas alterações mitocondriais uma das etapas que induziriam a transição. A incidência da PCM na puberdade é igual para ambos os sexo, contudo na vida adulta, 80\% dos pacientes são do sexo masculino com estatísticas apontando uma incidência de 13 homens afetados para cada mulher com idade entre 30 e 50 anos em áreas endêmicas (Bru mMer et al., 1993). A principal explicação para estas estatísticas está relacionada ao hormônio estrogênico feminino 17-beta-estradiol (E2) (Restrepo et al., 1984). Experimentos in vitro mostraram que o E2 inibe a transição do fungo de micélio para a forma patogênica de levedura (Restrepo et al., 1984; Salazar et al., 1988). P. brasiliensis possui uma proteína citosólica com alta especificidade a este hormônio (Loose et al., 1983). Acredita-se, portanto, que o hormônio atue como ligante competidor desta proteína impedindo-a de se ligar ao seu receptor específico de $P$. brasiliensis. Hipóteses sugerem que esta proteína citosólica seja receptora de sinais específicos durante a transição de micélio para levedura, uma vez que o tratamento do fungo como altas doses de 17-beta-estradiol não apresentam efeitos na formação de brotos na fase leveduriforme e apenas leves efeitos na transição da forma de levedura para micélio (Restrepo et al., 1984). 


\subsection{Sequenciamento De ESTs De Paracocidioides brasiliensis}

O sequenciamento de etiquetas de genes expressos (ESTs) deste fungo teve inicio em 2001 com o consorcio paulista formado por grupos de pesquisadores das seguintes Universidades: USP/Ribeirão; UNIFESP; UMC e UNIVAP. A estratégia deste consórcio foi construir bibliotecas de ESTs das fases micelial e leveduriforme de P. brasiliensis em vetor pCMV.SPORT6, sendo sequenciado os insertos dos clones por ambas as extremidades. Em paralelo um outro consórcio, da região central do Brasil, também construiu suas bibliotecas em vetor lambda ( $\lambda$ )-ZapII. Os resultados obtidos foram 13.490 sequencias de ESTs depositadas no GenBank do NCBI (Glodman et al., 2003) pelo consorcio paulista e 6.022 sequencias, também de ambas as fases, depositados no GenBank do NCBI pelo consorcio central (Felipe et al., 2003 e Felipe et al., 2005).

Estudos genômicos do fungo $P$. brasiliensis ainda estão em andamento com apenas um artigo (Reinoso et al., 2005) na literatura reportando o sequenciamento e análises de sete clones genômicos independentes, compreendendo um total de aproximadamente 50kb, demonstrando a organização de regiões intergênicas e introns de P.brasiliensis.

Entretanto, mais recentemente através de uma iniciativa do FGI - Fungal Genome Initiative - que é uma parceria entre o Broad Institute e várias comunidades de pesquisas em fungos estão sendo seqüenciados e anotados os genomas de três isolados de Paracoccidioides brasiliensis (Pb01, Pb03 e Pb18). Embora ainda não se tenha nenhuma publicação, os dados destes projetos de seqüenciamento de genomas já estão publicamente disponíveis para pesquisas e análises de comparação de seqüências (disponível em: http://www.broad.mit.edu/annotation/genome/paracoccidioides brasiliensis/MultiHome.html, acesso em: 14/01/2009). Já o genoma mitocondrial de Paracoccidioides brasiliensis do isolado Pb18 (Project ID: 16676) encontra-se seqüenciado e publicado (Cardoso et al., 2007) . No genoma mitocondrial de $P$. brasiliensis foi encontrado as três maiores subunidades do complexo da citocromo c oxidase Cox1p, Cox2p e Cox3p (Cardoso et al., 2007). A analise de anotação das sequencias ESTs do consorcio central sinaliza que em P. brasiliensis há síntese de ATP pelas vias metabólicas clássicas (Felipe et al., 2005).

O objetivo deste trabalho é identificar e caracterizar os genes nucleares de $P$. brasiliensis que participam direta ou indiretamente da biosíntese do complexo da citocromo c oxidase (COX) mitocondrial. Para isso identificamos os genes in sílico, testamos em ensaios de complementação heteróloga em mutantes de Saccaromyces cerevisiae e estudamos o 
padrão de expressão destes genes durante a transição morfológica de micélio pala levedura e de levedura para micélio.

Iniciamos uma busca no banco de dados Saccharomyces Genome Database, disponível em: http://www-genome.stanford.edu/ e selecionamos quarenta sequências de proteínas envolvidas nesta biosíntese do complexo da COX que foram utilizadas como sondas de identificação dos genes aqui estudados. Alem dos genes PbCOX4, PbCOX9, PbCOX12 e PbCOX16 de estudos anteriores (Bandeira e Nóbrega, 2008), identificamos mais quinze(15) novos genes desta via.

Até o momento, ainda não disponibilizamos de uma técnica bem definida para transformação ou indução de mutação (pontual ou deleções) em $P$. brasiliensis e a caracterização dos homólogos identificados in sílico foram realizadas por complementação funcional heteróloga em mutantes de Saccharomyces cerevisiae.

Dos quinze novos genes estudados quatro deles PbCOX6, PbCOX17, PbCOX19 e PbOXA1 complementam a deficiência respiratória dos respectivos mutantes de $S$. cerevisiae enquanto os genes PbCOX11, PbCOX17, PbCOX19 e PbSCO1 são capazes de substituir os homólogos à função de resistência ao peróxido de hidrogênio $\left(\mathrm{H}_{2} \mathrm{O}_{2}\right)$ nos respectivos mutantes de $S$. cerevisiae.

A primeira iniciativa de utilização desse procedimento (complementação heterologa) para caracterização de genes de $P$. brasiliensis foi realizada com o estudo da ornitina descarboxilase (ODC) que complementou com sucesso os transformantes do mutante nulo odc de S. cerevisiae com o gene PbODC de P. brasiliensis (Niño-Vega et al., 2004). Nesta época já havíamos conseguido com sucesso a complementação funcional heteróloga da capacidade respiratória do mutante de S. cerevisiae com gene PbCOX9.

A partir de análises de aproximadamente 12.000 seqüências aleatórias $P$. brasiliensis (RSTs - "Random Sequence Tags”) geradas a partir de uma biblioteca genômica construída em nosso laboratório, no vetor pUC18, acessamos a estrutura genômica de seis genes (PbCOX8, PbCOX11, PbMSS51, PbPET191, PbOXA1 e PbSCO1) de P.brasiliensis e a partir de análises por hibridização em membranas com sondas dos genes da citocromo c oxidase de P.brasiliensis identificamos clones referentes à maioria dos demais genes em uma biblioteca genômica construída em fosmídeos.

A análise da expressão dos genes estudados neste trabalho foi realizada utilizando-se a técnica de PCR quantitativo em tempo real. Esta análise mostra serem estes genes são modulados durante a transição morfológica do fungo, tanto de micélio para levedura quanto na transição reversa. 
Nossos resultados estão contribuindo para avançar o entendimento desta via de síntese tão complexa e essencial das células eucarióticas utilizando como sistema modelo o fungo $P$. brasiliensis em qual até então nada havia sido estudado.

\subsection{Sideróferos}

O ferro é um nutriente essencial requerido para o metabolismo de todos os seres vivos, porém encontra-se na forma de compostos insolúveis (óxidos-hidróxido). Os íons de ferro $\mathrm{Fe}^{+}$têm uma solubilidade muito baixa no $\mathrm{pH}$ neutro e conseqüentemente não podem ser diretamente utilizados pelos microorganismos. Eisendle et al., 2003 diz que o ferro representa um paradoxo muito significante em biologia, pois este metal é indispensável em diversos tipos de cofatores tais como centros de ferro-enxofre de grupo hemes, o que o torna essencial em processos metabólicos chaves, incluindo a fosforilação oxidativa. Além de sua utilidade vital este metal também pode atuar na oxidação deletéria de biomoléculas via "HaberWeiss/Fenton chemistry” (Halliwell e Gutteridge 1984) e, portanto, a concentração intracelular e nos fluidos biológicos de ferro deve ser altamente regulada e este controle é basicamente realizado em nível de captação e estocagem intracelular do metal (Haas, 2003). Desta forma fungos e bactérias foram obrigados a desenvolver um mecanismo altamente especializado para a mobilização de ferro e sobreviverem a bioindisponibilidade deste metal (Guerinot, 1994; Leong e Winkelmann, 1998) na natureza. Em baixas concentrações de ferro estes microorganismos sintetizam e secretam compostos de baixo peso molecular, que atuam como quelantes específicos de ferro chamados de sideróferos (Neilands, 1981). Subseqüentemente as células recuperam o ferro do complexo Ferri-siderófero via um sistema também altamente especializado (Winkelmann, 2002; Hissen et al., 2004). Além de agentes seqüestradores muitos fungos possuem sideróferos intracelulares que atuam com um compartimento de estoque de ferro (Matzanke et al., 1987).

A aquisição de ferro também é reconhecidamente um fator muito importante no processo de infecção por qualquer patógeno humano desde que este metal é rapidamente seqüestrado por proteínas com alta afinidade por ferro tais como a ferritina (Weinberg, 1999; Hissen et al., 2004) e por isso, os sideróferos freqüentemente têm sido reconhecidos também como fatores de virulência. Este fato é corroborado pelos relatos de que o transporte de sideróferos é requerido no processo especifico de infecção, denominado "invasão epitelial e penetração por Cândida albicans” (Heymann et al., 2002; Hu et al., 2002). Considerando que as vias biosintéticas de sideróferos são ausentes em células humanas, as vias de biosíntese de 
sideróferos em organismos patogênicos representam fortes candidatos a alvos de agentes quimioterápicos (Eisendle et al., 2003). O potencial uso de drogas conjugadas a sideróferos no processo de entrega de antibióticos a organismos específicos também tem sido relatado (Roosenberg et al., 2000).

“Como um organismo modelo é uma frustração o fato de que Saccharomyces cerevisiae não seja capaz de sintetizar nenhuma espécie de sideróferos embora este organismo seja altamente eficiente em captar e utilizar estes compostos (xenosideróferos) produzidos por outras espécies” (Lesuisse et al., 1998).

\subsection{A Biosintese De Sideróferos}

Os sideróferos podem ser divididos em três grupos distintos dependendo de sua composição química (catecols, carboxilatos e hidroxamatos) e com exceção do tipo caboxilato produzido por zigomicetos, a maioria dos fungos produz sideróferos do tipo hidroxamato (Van der Helm e Reissbrodt et al., 1994). O fato de S. cerevisiae não produzir sideróferos pode em parte explicar o porquê embora a captação e a utilização de ferro via sideróferos seja bem conhecida, a biosíntese destes compostos em nível molecular ainda esteja em estados iniciais (Haas, 2003). Plattner e Diekmann (1994) descrevem de maneira geral a via de biosíntese de sideróferos do tipo hidroxamato em fungos. De acordo com estes autores o primeiro estágio de comprometimento na via de biosíntese de sideróferos é a N5-hidroxilação da ornitina, que é catalisada pela ornitina N5-oxigenase gerando a N5-hidroxiornitina e a formação do grupo hidroxamato é conduzida pela transferência de um grupo acil de um derivado de Acil-CoA para a N5-hidroxiornitina. Adicionalmente alguns sideróferos requerem uma acetilação no grupamento amino_NH2 do hidroxamato, como no caso do coprogen e do triacethylfusarinine $\mathrm{C}$ e esta etapa ainda não foi geneticamente caracterizada (Plattner e Diekmann, 1994). A ligação de grupos hidroxamatos como no caso dos sideróferos do tipo ferrichrome e a incorporação adicional de aminoácidos são realizadas por enzimas do tipo “nonribosomal peptide synthetases” (NRPSs).

Os sideróferos desta classe freqüentemente possuem uma estrutura cíclica e/ou ramificada, contêm aminoácidos não-proteinogênicos incluindo D-aminoácidos. Carregam modificações como grupos $\mathrm{N}$-methyl e $\mathrm{N}$-formyl, ou são glicosilados, acilados, halogenados, ou hidroxilados. Às vezes são dímeros ou trímeros de subunidades idênticas. As proteínas do tipo NRPS constituem uma espécie de enzimas com uma constituição modular capaz de montar compostos a partir de uma considerável variedade de precursores tanto 
proteinogênicos como não proteinogêncos. Cada módulo consiste em diversos domínios com funções definidas como domínio de adenilação, domínio de condensação e um domínio carregador de peptídeos, que normalmente são separados por regiões espaçadoras curtas de aproximadamente 15 aminoácidos (Kleinkauf e Von Dohen, 1996; Weber e Marahiel, 2001).

A primeira ornitina N5-oxigenase caracterizada em fungos foi a ornitina N5-oxigenase de Ustilago maydis (Mei et al., 1993) que é codificada pelo gene SID1 (Haas, 2003). Subseqüentemente em 2003, uma ortologa de ornitina N5-oxigenase (SIDA) foi caracterizada em Aspergillus nidulans (Eisendle et al., 2003). A expressão de SID1 (U. maydis) e SIDA (A.nidulans) é reprimida em altas concentrações de ferro e a deleção destes genes leva ao bloqueio da síntese de todos os sideróferos do tipo hidroxamatos nestes fungos (Haas, 2003). Uma N5-hidroxiornitina: acetil-CoA-N5-transacetilase também já foi identificada em Ustilago sphaerogena (Neilands et al., 1987) e em Rhodotorula pilimanae (Ong e Emery, 1972) e proteínas NRPS já foram caracterizadas em U. maydis (Yuan et al., 2001) sendo codificada pelo gene SID2 e em A. nidulans (Oberegger et al., 2002) pelos genes SIDC e SIDB. Além de genes estruturais atuantes na síntese de sideróferos, vários outros genes têm sido caracterizados como transportadores ou como ativadores e repressores responsivos de ferro na síntese destes compostos (Haas, 2003).

Considerando a importância dos sideróferos tanto na sobrevivência, como no processo de infecção e estabelecimento de patogenicidade de fungos em hospedeiros humanos estamos apresentando os resultados iniciais obtidos na identificação e caracterização bioquímica e biosíntese destes compostos em Paracoccidioides brasiliensis. 


\section{OBJETIVOS}

2.1 Identificar nos bancos de seqüências ESTs e genomicas que foram gerados nos projetos de seqüenciamento de Paracoccidioides brasiliensis seqüências homólogas aos polipeptídeos de levedura Saccharomyces cerevisiae envolvidos na biogênese da citocromo c oxidase mitocondrial;

2.2 Selecionar os clones com insertos de seqüências de $P$. brasiliensis que apresentem similaridade significativa dentro dos valores de E-value $\leq 10^{-5}$ estabelecido para seqüenciamento completo do inserto seguindo de depósito dos dados no GenBank/NCBI;

2.3 Estudar a estrutura genomica destes genes verificando a existência e localização de introns;

2.4 Verificar o padrão de expressão destes genes de Paracoccidioides brasiliensis nas fases micélio e levedura e durante a transição dimórfica induzida por temperatura;

2.5 Verificar a capacidade de restaurar a atividade da citocromo oxidase por meio da complementação funcional heteróloga em mutantes Saccharomyces cerevisiae;

2.6 Verificar a presença de sideróferos em sobrenadantes de cultura de Paracoccidioides brasiliensis. 


\section{MATERIAL E MÉTODOS}

\subsection{Linhagens De Leveduras E Bactérias}

As linhagens de E. coli e as linhagens de levedura utilizadas neste trabalho estão listadas nas tabelas 1 e 2 .

TABELA 1: Cepas de Escherichia coli

\begin{tabular}{|c|c|}
\hline Linhagem & Genótipo \\
\hline $\mathrm{DH}_{10} \mathrm{~B}^{1,2}$ & $\begin{array}{c}\text { F mcrA } \Delta \text { (mrr-hsdRMS-mcrBC) } \phi 80 \text { dlacZ } \triangle M 15 \Delta l a c X 74 \text { deoR } \\
\text { recA1 endA1 oraD139 } \Delta \text { (ora, leu) } 7697 \text { galU galK } \lambda^{-} \text {rpsL } \\
\text { nupG }\end{array}$ \\
\hline SOLR $^{\mathrm{TM}}{ }^{3}$ & $\begin{array}{c}\text { e14-(McrA-) .(mcrCB-hsdSMR-mrr)171 sbcC recB recJ uvrC } \\
\text { umuC::Tn5 (Kanr) lac gyrA96 relA1 thi-1 endA1 } \lambda R \text { [F' proAB } \\
\text { lacIqZ.M15] Su-(nonsuppressing) }\end{array}$ \\
\hline XL1-Blue MRF ${ }^{33}$ & $\begin{array}{l}\text { A.(mcrA)183 .(mcrCB-hsdSMR-mrr)173 endA1 supE44 thi-1 } \\
\text { recA1 gyrA96 relA1 lac [F' proAB lacIqZ.M15 Tn10 (Tetr)] }\end{array}$ \\
\hline \multicolumn{2}{|l|}{$\begin{array}{l}\text { Referências } \\
\text { 1-GRANT et al., } 1990 \\
\text { 2-AUSUBEL et al; } 1995 \\
\text { 3-BN \#946306-11. Revisio }\end{array}$} \\
\hline
\end{tabular}


TABELA 2: Linhagens De Saccharomyces cerevisiae

\begin{tabular}{l|l|l}
\hline Linhagem & Genótipo & Referência \\
\hline W303 & $\begin{array}{l}\text { MAT a/ } \alpha \text { ade2-1, trp1-1, his3-115, ura3-1 } \\
\text { leu2-3, } 112, \rho^{+}, \text {can }\end{array}$ & $\begin{array}{l}\text { ROTHSTEIN, R., } \\
\text { Columbia University }\end{array}$ \\
\hline W303-1A & $\begin{array}{l}\text { MAT a, ade2-1, trp1-1, his3-115, ura3-1, leu2- } \\
\text { 3,112, } \rho^{+}, \text {can }\end{array}$ & $\begin{array}{l}\text { ROTHSTEIN, R., } \\
\text { Columbia University }\end{array}$ \\
\hline W303-1B & $\begin{array}{l}\text { MAT } \alpha, \text { ade2-1, trp1-1, his3-115, ura3-1, } \\
\text { leu2-3, } 112, \rho^{+}, \text {can }\end{array}$
\end{tabular}




\subsection{Meios De Cultura Para Bactéria}

Meio LB (Luria-Bertani): 1\% Triptona; 0,5\% Extrato de Levedura; 0,5\% $\mathrm{NaCl}$ e 0,1\% Dextrose pH 7,0

Meio LA (meio Luria-Bertani com adição de antibiótico ampicilina): 1\% Triptona; 0,5\% Extrato de Levedura; 0,5\% $\mathrm{NaCl}$ e 0,1\% Dextrose $\mathrm{pH}$ 7,0 ; ampicilina 50mg/mL

\subsection{Meio de Cultura para Levedura}

Meio WO (meio mínimo sem aminoácidos): 0,17\% YNB (Yeast Nitrogen Base) sem aminoácido; 0,5\% Sulfato de Amônio; 2\% Dextrose.

Meio EG (meio completo com fonte de carbono: Etanol + Glicerol): 1\% Y (Extrato de Levedura); 2\% P (Peptona); 2\% G (Glicerol); 2\% E (Etanol)

Meio YPD (meio completo com dextrose): 1\% Y (Extrato de Levedura); 2\% P (Peptona); 2\% D (Dextrose)

\subsection{Oligo-Inicidores Utilizados Para Seqüenciamento}

Para o seqüenciamento dos insertos dos clones originados das bibliotecas de ESTs -Expressed Sequence Tags, construída no vetor pCMV.SPORT6 (Invitrogen) foram utilizados os seguintes iniciadores:

$$
\begin{gathered}
\text { (99F) 5'-TAATACGACTCACTATAGGG-3’ } \\
\text { (100R) 5'-ATTTAGGTGACACTATAG-3’ } \\
\text { (140) 5' - TTTTTTTTTTTTTTTTTTTTTTT-3’ } \\
\text { (78SS) 5' - GTAAAACGACGGCCAGT-3’ } \\
\text { (79SR)5' - CAGGAAACAGCTATGAC-3’' }
\end{gathered}
$$

Para o sequenciamento dos clones originários das bibliotecas construídas no vertor Lambda ZAPII (Stratagene), utilizou-se os iniciadores:

$$
\begin{gathered}
\text { (99F) 5’ - TAATACGACTCACTATAGGG-3’ } \\
\text { (128T3) 5’ - ATTAACCCTCACTAAAGGGA-3’ }
\end{gathered}
$$


Para certificação das construções feitas com vetores pMGL3 e pMGL4 foi utilizado o iniciador (386) 5’-CAATATTTCAAGCTATAC-3’.

Para o sequenciamento dos clones gerados pela técnica de inserção de transposon foram utilizados os iniciadores:

(492) 5'-ACСТАСАACAAAGCTCTCATCAACC-3'

(493)5'-GCAATGTAACATCAGAGAATTTTGAG-3’

\subsection{Reação de PCR (Reação em Cadeia de Polimerase) de Seqüenciamento}

A reação de amplificação contém um volume final de $10 \mu \mathrm{L}$ com aproximadamente 20 nanogramas de DNA molde, 3 a 6 picomoles de oligo-iniciador, $40 \mathrm{mM}$ Tris pH9,0, $1 \mathrm{mM}$ $\mathrm{MgCl}_{2}$ e $2 \mu \mathrm{L}$ da mistura comercial “ABI PRISM Big Dye ${ }^{\mathrm{TM}}$ Terminator Cycle Sequencing Ready Reaction Kit (Applied Biosystems - PERKIN-ELMER)”, um kit que reúne a Ampli ${ }^{\circledR}$ tag DNA polymerase Fs, os nucleotídeos e os dideoxi terminadores (A- dRGG , C - dROX ; G - Dr110 E t -dTAMRA), ou DYEnamic ET terminator cycle sequencing Kit (Amersham Pharmacia Biotech Inc.). As amplificações foram realizadas no termociclador PCR PTC -100 TM Proga mMable Thermal Controler (MJ Research, Inc) sendo programado de acordo com as necessidades, como temperatura de desnaturação dos oligos-iniciadores, tamanho do fragmento de DNA a ser seqüenciado etc. Após a reação de amplificação o DNA é precipitado adicionando-se $5 \mu \mathrm{L}$ da solução NG (Glicogênio $1 \mathrm{mg} / \mathrm{mL}$ dissolvidos em $5 \mathrm{M}$ $\mathrm{NH}_{4} \mathrm{OAc}$ ) e $50 \mu \mathrm{L}$ de etanol $100 \%$. A mistura é incubada por no mínimo 30 minutos a $-80{ }^{\circ} \mathrm{C}$. Após o período de incubação centrifuga-se a mistura por 30 minutos $40000 \mathrm{rpm}$ a $4{ }^{\circ} \mathrm{C}$ e despreza-se o sobrenadante. O DNA precipitado é lavado duas vezes com $110 \mu \mathrm{L}$ de etanol$80 \%$ centrifugando-se por 15 minutos $4000 \mathrm{rpm}$ a $4{ }^{\circ} \mathrm{C}$ cada. Secado a vácuo e submetido ao sequenciamento.

\subsection{Seqüenciamento}

O seqüenciador utilizado é o 3100 Genetic Analyzer - Applied Biosystems/HITACHI, com capacidade para seqüenciamento de 96 amostras simultaneamente. O método de seqüenciamento utilizado é o resultado de um aperfeiçoamento do método original de Sanger que consiste em submeter amostras de pDNA a um processo de PCR linear utilizando-se além 
dos quatro deoxinucleotídeos trifosfato (dNTPs), os dideoxi fluorescentes específicos "Dye Terminators”. Após a reação de PCR e purificação do DNA amplificado este é diluído em formamida e as amostras são carregadas no aparelho seqüenciador. No eletroferograma temos a fluorescência verde como indicativa da base nitrogenada Adenina, a vermelha para Citosina, azul para Guanina e preta para Timina.

\subsubsection{Análise dos Cromatogramas de Seqüenciamento}

Os cromatogramas obtidos por seqüenciamento foram analisados utilizando-se a ferramenta SeqManII do programa DNASTAR- Lasergene.

Alternativamente também se utilizou a ferramenta phred com o parâmetro de qualidade 20. Os arquivos no formato FASTA foram avaliados através de um programa de computador "script" que separa as seqüências FASTAs de melhor qualidade e maior tamanho de pares de base (bp). Para o agrupamento das seqüências utilizou-se o programa CAP3.

\subsection{Identificação da Fase Aberta de Leitura (“ORF - Open Reading Frame”)}

As seqüências consensos no formato FASTA foram analisada quanto à presença de fase aberta de leitura utilizando-se a ferramenta ORFFinder (Open Reading Frame Finder) do NCBI (Nacional Center for Biotechnology information) disponível em: http://www.ncbi.nlm.nih.gov/gorf/gorf.html.

\subsection{Análises das Seqüências das Proteínas de Paracoccidioides brasiliensis}

Múltiplo alinhamento com as proteínas homólogas foram gerados pelo programa Clustal/W, disponível em: http://searchlauncher.bcm.tmc.edu/multi-align/multi-align.html. Utilizando o programa Box Shade disponível em: http://www.ch.embnet.org/software/BOX form.html, os resíduos idênticos foram pintados em preto e os resíduos com propriedades químicas semelhantes foram pintados em cinza. Predições de peso molecular e das características dos aminoácidos das novas proteínas de P. brasiliensis foram determinadas através da ferramenta EditSeq do programa DNASTARLasergene. Predição de domínios característicos de regiões transmembrana foi realizada utilizando-se a ferramenta TMH MM Server v.2.0, disponível em: http://www.cbs.dtu.dk/services/TMH MM/. 


\subsection{Excisão das ORFs}

Após a localização da Fase aberta de leitura na seqüência consenso de interesse esta é submetida à análise quanto à presença de sítios de reconhecimento de enzimas de restrição, utilizando-se o programa NEBcutter V2.0 disponível na página da New England Biolabs Inc. (www.neb.com). Quando presentes os sítios das enzimas apropriadas que excisão a fase aberta de leitura direcionada para a ligação do vetor de expressão específico estes são confirmados com uma digestão analítica seguida de análise em gel 1\% agarose. Após a confirmação segue-se a digestão preparativa e o fragmento de interesse é isolado por eletroforese preparativa em gel 1\% agarose e extraído do gel por eletroeluição. Neste processo as bandas de DNA desejadas são recortadas do gel com estilete e colocadas em sacos de diálise contendo tampão de TBE 1:10 (8 mM Tris; 11,3 mM ácido bórico e 0,25 mM EDTA, pH entre 8,0 a 8,3) o mesmo tampão é usado na cuba de eletroforese. Liga-se a cuba a uma fonte de eletricidade (Power PAC3000, da BioRad) e deixa-se por 5 minutos a 500V. O DNA eletroluído da agarose fica em solução no tampão, dentro do saco de diálise. Esta solução contendo o DNA é recolhida e a esta solução ( 400 $\mu \mathrm{L})$ adiciona-se 1/20 do volume de 1MTris pH8,0 e fenol em volume igual ao volume total. A mistura é vigorosamente homogeneizada em aparelho de vortex e centrifugada por 10 minutos. A fase aquosa é transferida para novos tubos eppendorf e uma nova extração é feita com o mesmo volume de éter. Á fase aquosa adiciona-se 1/20 do volume de $5 \mathrm{M} \mathrm{NaCl}$ e 2,5 vezes o volume total de etanol $100 \%$. A mistura é incubada a $-80{ }^{\circ} \mathrm{C}$ por no mínimo 15 minutos. Após o período de incubação centrifuga-se por 10 minutos a $13000 \mathrm{rpm}$ e aspira-se o sobrenadante. O precipitado de DNA é lavado duas vezes com etanol 80\%, O precipitado de DNA é secado a vácuo (VR-I Heteorac, da Heto) e ressuspendido em 10 mM Tris, 1 mM EDTA pH7,5.

Quando não existe a presença de sítios de restrição apropriados faz-se necessário a síntese de oligos-iniciadores específicos.

\subsection{Preparação do Vetor de Expressão}

O plasmídeo selecionado para o estudo de expressão é digerido com as enzimas cuidadosamente escolhidas para cada caso. Após digestão enzimática preparativa, adiciona-se à reação a enzima CIP-Calf Intestine Phosphatase para desfosforilação das extremidades 5' 
do plasmídeo. O DNA plasmidial aberto é isolado por eletroforese em gel 1\% agarose e recuperado do gel por eletroeluição, purificado por extração com fenol e éter e precipitado com etanol.

\subsection{Ligação do Fragmento de DNA ao vetor}

A ligação do fragmento de DNA de interesse ao vetor apropriado é realizada utilizando-se o Kit de ligação Fast Link ${ }^{\mathrm{TM}}$ DNA Ligation Kit em um volume final de $15 \mu \mathrm{L}$ seguindo as instruções do fabricante (EPICENTRE TECHNOLOGIES). Utiliza-se $5 \mu \mathrm{L}$ da mistura da ligação para a transformação em $E$. coli $\mathrm{DH}_{10} \mathrm{~B}$ (célula competente, preparada pelo método químico com $\mathrm{CaCl}_{2}$ ) por choque térmico. Os pDNAs dos transformantes de E. coli são extraídos por minipreparações (mini-prep) e analisados com as enzimas de restrição apropriadas ou por seqüenciamento.

\subsection{Reação de Inserção de Transposon}

Para Inserção de Transposon utilizou-se o Kit EZ::TN ${ }^{\mathrm{TM}}<\mathrm{KAN}-2$ > Insertion Kit [EZ::TN ${ }^{\mathrm{TM}}$ Transposase eZ:TN ${ }^{\mathrm{TM}}$ Transposon eZ:TN ${ }^{\mathrm{TM}}$ 10X Reaction Buffer eZ:TN ${ }^{\mathrm{TM}} 10 \mathrm{X}$ Stop Solution e os primers KAN-2 FP-1 Forward e KAN-2 RP-1 Reverse] seguindo as instruções do fabricante (EPICENTRE Technologies).

\subsection{Preparo de Célula Competente de E.coli pelo método químico}

Um inóculo de células de Escherichia coli é feito em $50 \mathrm{~mL}$ do meio LB e incubado sob agitação de $220 \mathrm{rpm}$ no "Shaker" New Brunswick Scientific a $37{ }^{\circ} \mathrm{C}$ por aproximadamente 1 hora. O crescimento é monitorado por densidade óptica através do aparelho nefelômetro KIIet até que a leitura atinja o ponto 100 de escala do aparelho o que caracteriza o crescimento em fase exponencial. Transfere-se a cultura para um tubo cônico Corning de $50 \mathrm{~mL}$, centrifuga-se na SORVALL RC-5B, rotor AS-600 por 10 minutos a 5000 rpm a $4{ }^{\circ} \mathrm{C}$. Despreza-se o sobrenadante e faz-se uma lavagem das células com $15 \mathrm{~mL}$ de 10 $\mathrm{mM} \mathrm{CaCl} 2,10 \mathrm{mM}$ Tris pH8,0 centrifugando-se por 10 minutos a $5000 \mathrm{rpm}$ a $4{ }^{\circ} \mathrm{C}$. Desprezase o sobre e ressuspende-se as células em $15 \mathrm{~mL}$ de $50 \mathrm{mM} \mathrm{CaCl}_{2}, 10 \mathrm{mM}$ Tris pH8,0 e incuba-se a células em suspensão no gelo por 30 minutos. Centrifuga-se novamente por 10 
minutos a $5000 \mathrm{rpm}$ a $4{ }^{\circ} \mathrm{C}$ e resuspende-se as células competentes em $3 \mathrm{~mL}$ de $50 \mathrm{mM}$ $\mathrm{CaCl}_{2}, 10 \mathrm{mM}$ Tris pH8,0.

\subsection{Transformação Bacteriana por choque térmico}

Em volume de $200 \mu \mathrm{L}$ de células competente, adiciona-se $5 \mu \mathrm{L}$ da mistura de ligação em e incuba-se no gelo por 15 minutos. Submete-se a um choque térmico a $42{ }^{\circ} \mathrm{C}$ por 2 minutos e incuba-se no gelo por 1 minuto. As células são transferidas para um tubo cônico Corning $15 \mathrm{~mL}$ contendo 3,0 mL de LB. Incuba-se sob agitação de 220 rpm por 1 hora a 37 ${ }^{\circ} \mathrm{C}$. Após este período de incubação centrifuga-se a mistura contendo as células despreza-se parte do sobrenadante. As células são novamente resuspendidas e plaqueadas em meios contendo um agente apropriado para seleção dos transformantes.

\subsubsection{Método Seletivo de Clones}

Os clones transformantes são coletados com o auxílio de palitos de dentes esterilizados e transferidos de maneira ordenada para nova placa de meio apropriado e incubados em estufa $37^{\circ} \mathrm{C}$ por aproximadamente 15 horas. Dos clones crescidos extrai-se o DNA plasmidial (pDNA) que é analisado em gel analítico 1\% agarose e selecionados por digestão enzimática com as enzimas apropriadas ou por seqüenciamento.

\subsection{Extração de pDNA de Bactéria [método alcalino]}

Com auxílio de palito de dente de ponta chata coleta-se uma amostra dos clones crescidos em placa contendo meio apropriado que é transferida para um tubo Eppendorf contendo 0,1 mL de (50 mM glicose; 10 mM EDTA; 25 mM Tris pH8,0; $2 \mathrm{mg} / \mathrm{mL}$ "lysozyme” e 0,33 mg/mL RNAase). Adiciona-se $0,1 \mathrm{~mL}$ de $(0,2 \mathrm{~N} \mathrm{NaOH} ; 1 \% \mathrm{SDS})$. Mistura-se gentilmente por inversão e incuba-se por 3 minutos a temperatura ambiente. Adiciona-se 0,1 mL de 3M NaOAc pH4,8 e incuba-se no gelo por 5 minutos. Após período de incubação, centrifuga-se por 5 minutos, 13000 rpm e coleta-se o sobrenadante em tubo Eppendorf novo $(-250 \mu \mathrm{L})$. Adiciona-se $0,7 \mathrm{~mL}$ de $100 \%$ etanol e incuba-se a $-80{ }^{\circ} \mathrm{C}$ por 20 minutos. Centrifuga-se por 5 minutos a 13000 rpm e despreza-se o sobrenadante. O pDNA precipitado é lavado duas vezes com $0,3 \mathrm{~mL}$ de $80 \%$ Etanol/EDTA, centrifugando-se 5 
minutos 13000 rpm cada. Seca-se o precipitado a vácuo e ressuspende-se o pDNA em 10 mM Tris pH8,0; 1 mM EDTA.

\subsection{Gel de Agarose para Eletroforese}

Para a eletroforese, utiliza-se gel 1\% agarose. Utilizamos 0,4 g de agarose em $40 \mathrm{~mL}$ de TBE (80 M Tris, 113 mM ácido bórico, 2,5 mM EDTA, pH8,0). A mistura é aquecida no aparelho de microondas até completa solubilização da agarose. Adiciona-se $1 \mu \mathrm{L}$ de Brometo de etidío (1 mg/mL) e despeja-se a solução de gel numa cuba apropriada contendo um pente apropriado para polimerização. Após a polimerização a cuba com o gel é transferida para a cuba de eletroforese. O tampão de eletroforese utilizado é o mesmo utilizado para a preparação do gel (TBE). A eletroforese ocorre em $150 \mathrm{~V}$ por aproximadamente 30 minutos.

Após a corrida o gel é transferido para o transluminador onde o DNA pode ser observado e fotografado sob excitação de luz UV.

\subsection{Transformação de Levedura pelo método de LiOAc}

Um inóculo de levedura é feito em $10 \mathrm{~mL}$ de meio YPD utilizando-se um erlenmeyer de $50 \mathrm{~mL}$ e incubado por 24 horas, sob agitação de $220 \mathrm{rpm}$ a $30{ }^{\circ} \mathrm{C}$ no incubador C24 Classic Benchtop Incubator Shaker da New Brunswick Scientific. Após período de incubação cerca de $200 \mu 1$ da cultura é transferida para um novo erlenmeyer de $50 \mathrm{~mL}$ contendo $10 \mathrm{~mL}$ de YPD e incuba-se novamente sob agitação de $220 \mathrm{rpm}$ a $30{ }^{\circ} \mathrm{C}$ por 4 horas. A cultura de células é transferida para um tubo Corning de $15 \mathrm{~mL}$ e precipitada por centrifugação na centrífuga SORVALL (RC-5B, rotor SA-600) por 10 minutos a $5000 \mathrm{rpm}$ a $20{ }^{\circ} \mathrm{C}$. O sobrenadante é desprezado e as células são ressuspendidas em 1,0 mL de TEL (10 mM Tris pH 7,5; 0,1M LiOAc; 1 mM EDTA), homogeneizando-se sempre gentilmente. As células são transferidas para um tubo Eppendorf de 1,5 mL. Centrifuga-se por 2 minutos na microcentrífuga (Spectrofuge $16 \mathrm{M}$ da National Labnet Co). O sobrenadante é desprezado e as células são novamente ressuspendidas em $100 \mu \mathrm{L}$ de TEL, homogeneizando gentilmente com a pipeta. Incuba-se por 5 minutos à temperatura ambiente e adiciona-se $5 \mu \mathrm{L}$ de "carrier" DNA de salmão da Sigma, na concentração $(8 \mathrm{mg} / \mathrm{mL})$ e $2 \mu \mathrm{L}$ a $3 \mu \mathrm{L}$ do pDNA desejado. Deixa-se 10 minutos à temperatura ambiente e adiciona-se 0,8 mL de PEG 40\% (PEG-3640 em TEL), homogeneizando-se por inversão. Incuba-se por 15 minutos à temperatura ambiente, sem agitação. As células são transferidas para um choque térmico a $42{ }^{\circ} \mathrm{C}$ por 12 minutos. 
Centrifuga-se por 5 minutos na microcentrífuga e remove-se o sobrenadante. As células são lavadas em 0,5 mL de TE (10 mM Tris pH 7,5; 1 mM EDTA) centrifugando-se por 2 minutos. O sobrenadante é removido com a pipeta e as células são ressuspendidas em $150 \mu \mathrm{L}$ de TE. Em seguida são plaqueadas em meio seletivo.

\subsection{Extração de pDNA de Levedura [modificado por Alex Tzagoloff Columbia University]}

Um inóculo das células do clone transformante crescido em placa de EG é coletado e transferido para um tubo Eppendorf contendo 0,5 mL de H2Odd (destilada e deionizada). As células são precipitadas centrifugando-se por 1minuto a 13000 rpm. O sobrenadante é descartado e as células são lavadas com 0,3 mL de 1,2 M Sorbitol centrifuga-se por 5 minutos a 13000 rpm. As células são ressuspendidas em 0,2 mL de solução de Zymolyase (1,2M sorbitol; 0,1 M Citrato pH 7,0; 60 mM EDTA; 0,4 M $\beta$ - mercapto /Etanol (v/v) e 1 mg/mL Zymolyase) e incubadas por aproximadamente 25 minutos a $37^{\circ} \mathrm{C}$. Após o período de incubação a $37{ }^{\circ} \mathrm{C}$, transfere-se o protoplasto para o gelo e adiciona-se $0,2 \mathrm{~mL}$ de $1,2 \mathrm{M}$ Sorbitol. Centrifuga-se por 5 minutos a $13000 \mathrm{rpm}$ e despreza-se o sobrenadante. O protoplasto é lavado duas vezes com 0,3 mL de 1,2M sorbitol centrifugando-se por 5 minutos a $13000 \mathrm{rpm}$ cada. Após a lavagem, ressuspende-se o protoplasto em 0,1 $\mathrm{mL}$ de $(50 \mathrm{mM}$ glicose; 25 mM Tris pH 8,0; 10 mM EDTA e $250 \mu \mathrm{g} / \mathrm{mL}$ RNAse). Adiciona-se 0,2 mL de (0,2 N NaOH; 1\% SDS) agitando-se gentilmente por inversão e deixa-se por 5 minutos a temperatura ambiente. Adiciona-se $150 \mu \mathrm{L}$ de 3M NaOAc pH 4,8 e incuba-se no gelo por mais 10 minutos. Centrifuga-se por 5 minutos a 13000 rpm e coleta-se o sobrenadante em um tubo eppendorf novo ( 200 $\mu \mathrm{L})$. O pDNA é precipitado adicionando-se $1 \mathrm{~mL}$ de 100\% etanol e incubando-se a $-80{ }^{\circ} \mathrm{C}$ por 15 minutos seguido de centrifugação por 5 minutos a 13000 rpm. O sobrenadante é desprezado e o precipitado de pDNA é ressuspendido em 0,3 mL de $2 \mathrm{M}$ $\mathrm{NH}_{4} \mathrm{OAc}$. Em seguida adiciona-se $1 \mathrm{~mL}$ de $100 \%$ de Etanol e incuba-se a $-80{ }^{\circ} \mathrm{C}$ por 15 minutos. O pDNA é precipitado centrifugando-se por 15 minutos a $13000 \mathrm{rpm}$. O sobrenadante é desprezado e o precipitado de pDNA é lavado duas vezes com 80\% Etanol/EDTA centrifugando-se por 5 minutos a 13000 rpm, cada. O pDNA é secado a vácuo e redissolvido em $20 \mu \mathrm{L}$ de H2Odd. Utiliza-se $10 \mu \mathrm{L}$ para transformação em E.coli. 


\subsection{Extração de RNA total de Paracoccidioides brasiliensis [método adaptado por Nobrega, $M$ ]}

Aproximadamente 5 gramas de células foram rompidas por maceração em nitrogênio líquido e imediatamente misturada com 20 mL de STE (20 mM Tris pH 7,5; 1 mM EDTA; 0,2\% SDS) e o mesmo volume de PCI (fenol:clorofórmio: álcool isoamílico 25:24:01). A mistura foi homogeneizada com 2 pulsos de 15 segundos em um homogeneizador Heavy Duty Laboratory Blender (WARING LABORATORIES \& SCIENCE) e em seguida centrifugada por 10 minutos a $6000 \mathrm{rpm}$ em temperatura de $4{ }^{\circ} \mathrm{C}$. A fase aquosa foi coletada e submetida a duas extrações com $20 \mathrm{~mL}$ PCI e uma terceira extração foi realizada com $20 \mathrm{~mL}$ de clorofórmio. O RNA foi precipitado com adição de 1:20 volumes de $5 \mathrm{M} \mathrm{NaCl}$ e 2.5 volumes de $100 \%$ etanol e incubação a $-80{ }^{\circ} \mathrm{C}$ por 30 minutos. O RNA foi coletado por centrifugação por 10 minutos a $6000 \mathrm{rpm}$ a $4{ }^{\circ} \mathrm{C}$ e lavado duas vezes com $80 \%$ etanol. O precipitado foi secado a vácuo e redisolvido em $3 \mathrm{~mL}$ de TE $(10 \mathrm{mM}$ Tris $\mathrm{pH}$ 7,5; $1 \mathrm{mM}$ EDTA). Para verificar a integridade do RNA aproximadamente $5 \mu \mathrm{L}$ do RNA total foi analisado em gel 1\% agarose, corado com brometo de etídeo e visualizado sob luz UV. Tratamento com DNaseI-RNase-free (Ambion) foi feito em alíquotas de $100 \mu \mathrm{L}$ de acordo com o protocolo do fabricante. A ausência de DNA contaminante foi verificada por reação de PCR através de testes de amplificação do gene PbGP43 de $P$. brasiliensis (Cisalpino et al., 1996) utilizando os oligos nucleotídeos senso 5'-TTCGAAGCAGGCGGGA e anti-senso 5'TCGATAGTATATGCTCACTTT. O oligo-nucleotídeo anti-senso alinha com a região intrônica do gene $P b G P 43$.

\subsection{Reação de PCR em tempo real (RT-qPCR)}

A abundância dos transcritos dos genes de $P$. brasiliensis foi medida por reação de PCR em tempo real utilizando tanto a tecnologia TaqMan (Applied Biosystems) quanto a de SYBR green (Invitrogen) para quantificar a expressão dos genes pelo método $2^{\text {-DDCt }}$ (Livak e Schmittgen 2001). Os oligos nucleotídeos e as sondas para cada gene alvo foram desenhados e sintetizados pelo sistema Assay-by-Design ${ }^{\mathrm{SM}}$ solfware (Applied Biosystems) enquanto que os oligos nucleotídeos para a amplificação do gene PbeIF3 (Nunes et a., 2005) utilizado como controle endógeno foi feita através do sistema Custom TaqMan ${ }^{\circledR}$ MGB ${ }^{\text {TM }}$ Probe (esta forma de síntese de oligos iniciadores foi utilizada quando se utilizou a tecnologia TaqMan). Para os oligos iniciadores utilizados com a tecnologia SYBR Green utilizou-se o ferramenta 
“PrimerQuest” da empresa Integrated DNA Technologies (idtdna) disponível no endereço eletrônico http://www.idtdna.com/Scitools/Applications/Primerquest/. O RNA total do fungo P. brasiliensis foi extraído em seis pontos (0, 5, 10, 24, 48 e 120 horas) durante a transição dimórfica induzida por mudança de temperatura de $25{ }^{\circ} \mathrm{C}$ (forma de micélio) para $37{ }^{\circ} \mathrm{C}$ (forma de levedura) e na transição contrária. A transcrição reversa foi realizada com $5 \mu \mathrm{g}$ de RNA total utilizando-se o conjunto de reagentes High-Capacity cDNA Archive Kit (Applied Biosystems) de acordo com as instruções do fabricante. A reação de PCR em tempo real foi realizada com o aparelho de PCR em tempo real ABI Prism 7300 sequence detection system (Perkin-Elmer Applied Biosystems). As condições de termociclagem compreenderam um estágio inicial de $50{ }^{\circ} \mathrm{C}$ por 2 minutos seguidos de 10 minutos a $95^{\circ} \mathrm{C}$ mais 40 ciclos de 15 segundos a $95{ }^{\circ} \mathrm{C}$ e 1 minuto a $60{ }^{\circ} \mathrm{C}$. Quando utilizamos a tecnologia SYBR Green, as reações seguiram as instruções do fabricante utilizando as condições de termociclagem recomendadas para os instrumentos $\mathrm{ABI}$. 
TABELA 3: Lista de Primers e Probes para PCR em Tempo Real (RTqPCR) pela Tecnologia TaqMan

\begin{tabular}{l|l}
\hline Gene & Primers and Probes \\
\hline$P b C O X 2$ & $\begin{array}{l}\text { Forward- ATTTGTAGTATCAGCAGCGGATGT } \\
\text { Reverse- CCCGGATATGCATCACATTTAATACCT } \\
\text { Probe- ATGGACACGCAAATGA - FAM }\end{array}$ \\
\hline$P b C O X 4$ & $\begin{array}{l}\text { Forward- CCGCAAGCGTCCAATTGAAC } \\
\text { Reverse- CCAATGTACTCCATCTTGACAACGT } \\
\text { Probe- CCGCACTCAGAACAA - FAM }\end{array}$ \\
\hline$P b C O X 5 A$ & $\begin{array}{l}\text { Forward- CAACAGAGCCGCTCAATGG } \\
\text { Reverse- GGCTAGTGTCGGATTGGCAAT } \\
\text { Probe- CTACGGCTGAACATGCC - FAM }\end{array}$ \\
\hline$P b C O X 6$ & $\begin{array}{l}\text { Forward- GCTGCACGGAGGGTCAA } \\
\text { Reverse- GACTTTGGCTTTGATGCCTTCA } \\
\text { Probe- ACTTCCCCACCGCCGTC - FAM }\end{array}$ \\
\hline$P b C O X 9$ & $\begin{array}{l}\text { Forward- GCTTGTATGCCCGTATCGAATC } \\
\text { Reverse- GGACGGTAAGAAGTCTAGTCAAGGA } \\
\text { Probe- CCTTGTGCGCGCTCG - FAM }\end{array}$ \\
\hline$P b C O X 12$ & $\begin{array}{l}\text { Forward- GCCAAGGGCGAGGACTT } \\
\text { Reverse-TCTGTAGGCGAGGTAGAACTGTT } \\
\text { Probe- CCGCCCATGCAGACAG - FAM }\end{array}$ \\
\hline$P b C O X 16$ & $\begin{array}{l}\text { Forward- TCCAACTCCTTCGGCTCAAC } \\
\text { Reverse- GAGGTTTGCGCGGTATTTGG } \\
\text { Probe- CACCCAGGCGTTCAC - FAM }\end{array}$ \\
\hline$P b C O X 17$ & $\begin{array}{l}\text { Forward- GGACGATTGCATGCTCTTCTC } \\
\text { Reverse- AGTGGTCGACATTCCTGTTGTG } \\
\text { Probe- CAGGGTCGTCTGATTTT - FAM }\end{array}$ \\
\hline$P b C O X 19$ & $\begin{array}{l}\text { Forward- CCGCAAGTTAGCCAAGTCCTAT } \\
\text { Reverse- GCACTCTGGAGCCATTAAATTGTGA } \\
\text { Probe- CCATGCGGCAAGACAA - FAM }\end{array}$ \\
\hline
\end{tabular}


3.20.2 Lista de Oligos iniciadores Utilizados Nos Experimentos de PCR em Tempo Real (Real Time - RTqPCR) pela Tecnologia SYBR Green

\section{Pbcox2}

Forward: CAAGATTTGTAGTATCAGCAGCGG

Reverse: CCGCAGATTTCAGAGCATTGTCCA

PbcoX4

Forward: ATTGAACGTTGTTCTGAGTGCGGC

Reverse: AAAGTCAGCCATGGTCTTGGGTTC

\section{PbCOX5A}

Forward: TGAAGGTCGATTGGCACGAGATGA

Reverse: AGAACACGACGAATGAGATGGCGA

PbcoX6

Forward: TGCTGCACATGAGGAGGAAACCTT

Reverse: AGTTCGAAGACATCCTGAACGGCA

PbcoX8

Forward: ATGGCCAGTCCTTTCCATTACCCA

Reverse: TTTGCCAGACAGCAATAGCGAAGG

Pbcox9

Forward: AACCTTCGCCTACСТCTTCTGGTA

Reverse: ATTCGATACGGGCATACAAGCGGT

PbcoX11

Forward: TGCCACAGATAGCACCATTCTGGA

Reverse: AGCGCTGCTGCTTACAGACAAATG

PbCOX12

Forward: TCGATCGGTAAATGGTTGCCGAGA Reverse: ATAAGGGACTTGACCCGTGGGATT 


\section{PbCoX13}

Forward: TGATTCCCGTCATCATCCTTGCGA

Reverse: TTGGTGCGAATGTTCTGGTAGGGA

\section{PbC0X15}

Forward: TTTGTCCTACCAGCGGCCTACTTT

Reverse: AACCATCCACCAACCAATGATGCC

\section{PbC0X16}

Forward: TCCTCTTCGGCCTCCCATTCATTA

Reverse: ATATCCTCCGCCGTGGATTCCTTT

PbcoX17

Forward: CATGCTGCGTCTGCAAACCTGAAA Reverse: ACCCGGCCATGCAACTCTTATACT Pbcox19

Forward: ATATCAAACCCAAACCGCCAGAGC Reverse: TGCGGCAAGTCTCATCATTCACAC

\section{Pbc0X23}

Forward: GAAGGCGAAGCCCATGTTCACAAA Reverse: GCCGCATGCATTTGATACTGCGAT

PbPET100

Forward: AATCAACAATGCTCAGCGCCATCC Reverse: ACGGAGAAGCGTTCTTCGAGGTTT

\section{PbPET112}

Foward: ACACGATGGCATTGCTAAGGAGGA

Reverse: ATCTCGATAAGAGGGCGCGAAACA

\section{PbPET191}

Forward: TGCCTCCAACAATCCGACTGCATA Reverse: GGCCCTTGCGTAATTGCTGACATT 


\section{PbSC01}

Forward: TCTGTTCTCCGGCCCATCTTCATT

Reverse: TTTGCACACATGCTTCACCTGCTC

\section{PbMSS51}

Foward: GTGTGCGACACAATCCGGCAAATA

Reverse: TCTCGTCACCTGCCTCATGTTTCT

\section{Pb0XA1}

Forward: AGTTGATGAAGCTGGCGTATCCGA

Reverse: AAGAGTGGATCGTGCACCGTAACA

\section{PbATP4}

Forward: GAGCCAATCACACCAATGCCGTTA

Reverse: ACTGCACCCATGAGTCAAGAACCT

\section{PbATP7}

Forward: AGCACTTCAAGTCGTTCACTCCCT

Reverse: GTTCAACCTTGTCCTTCGTCTCCT

\section{PbRIP1}

Forward: GGTTGTTAACTGCTGTTGGTGCGA

Reverse: GGGTTTGCCTCGCCATTTGATGAT

\section{PbQCR7}

Forward: TCCCAAGGAAGCTTATGACCGTGT

Reverse: TCGACGTCCTCTTCTGGTTTGGTT

\section{PbNDI1}

Forward: TGAACTTGTCTTAACCTCCGCT

Reverse: AGGGAGCACGATTAGTTTCAGCGA 


\subsection{Síntese de cDNA POLI(T) Para Clonagem do mRNA de Gene PbSCO1}

Para Clonagem do mRNA do Gene PbSCO1 utilizou-se o kit de reagentes da Invitrogen. A síntese de cDNA poli(T) seguiu as instruções do manual do fabricante (Invitrogen (Cloned AMV RT Module). A reação foi preparada da seguinte forma:

Em tubos de PCR $(0,6 \mathrm{~mL})$ foram adicionados $5 \mu \mathrm{L}$ (aproximadamente $1 \mu \mathrm{g}$ ) de RNA total de Paracoccidioides brasiliensis, $1 \mu \mathrm{L}$ da mistura de dNTPs (25 mM cada), $1 \mu \mathrm{L}$ (820

$\mathrm{ng} / \mu \mathrm{L})$ de GeneRacerTM oligo- dT primer 5'GCTGTCAACGATACGCTACGTAACGGCATGACAGTG(T)18-3' (54 bases) e $5 \mu \mathrm{L}$ de $\mathrm{H}_{2} \mathrm{O}$ dd esterilizada. Esta mistura foi incubada a $65^{\circ} \mathrm{C}$ por 5 minutos e resfriada rapidamente em gelo por dois minutos. Em seguida adicionou-se $2 \mu \mathrm{L}$ de $10 \mathrm{X}$ PCR buffer, $1 \mu \mathrm{L}$ da solução RNaseOut (40 U/ $\mu \mathrm{L}$ ), 1,3 $\mu \mathrm{L}$ da enzima transcriptase reversa (Cloned AMV RT_ 5 $\mathrm{U} / \mu \mathrm{L}$ ) e $4 \mu \mathrm{L}$ de $\mathrm{H}_{2} \mathrm{O}$ dd esterilizada. A mistura contendo um volume total de $20 \mu \mathrm{L} \mathrm{H}_{2} \mathrm{O}$ dd esterilizada foi incubada a $45{ }^{\circ} \mathrm{C}$ por um hora e $85{ }^{\circ} \mathrm{C}$ por 15 minutos e estocada a $-80{ }^{\circ} \mathrm{C}$. Para amplificação do gene PbSCO1 utilizamos $1 \mu \mathrm{L}$ de cDNA poli(T) por reação.

\subsection{Hibridização em Membrana}

Para identificação de clones na biblioteca genômica de $P$. brasiliensis construída em vetor do tipo fosmid utilizamos a técnica de hibridização em membrana $\left(\sim 110 \mathrm{~cm}^{2}\right)$ contendo 1152 clones cada. Foram analisados no total 2304 clones. Para marcação das sondas seguimos o protocolo do fabricante do kit de marcação (Gene Images Random Prime Labelling Module - Amersham Bioscienses). As reações de hibridizações nas membranas seguiram as instruções do fabricante do kit de detecção (Gene Images CDP-Star detection module Amersham Bioscienses) inserindo algumas modificações no volume (para menos) das reações:

A membranas foram inicialmente umedecidas em solução 5 X SSC [20 X SSC (0.3 M $\mathrm{Na} 3$ citrato, $3 \mathrm{M} \mathrm{NaCl}$ )]. Em seguida colocadas em tubos (biômetra com tampa) com a face contendo o DNA, voltada para o interior do tubo. Adiciona-se a solução de pré-hibridação [(5 X SSC, 0.1\% SDS, 5\% (w/v) sulfato de dextran e 1:20 (v/v) líquido de bloqueio)] na proporção de $\sim 0.15 \mathrm{~mL} / \mathrm{cm}^{2}$ (15 mL no tubo médio) e incuba-se por aproximadamente 1 hora a $60{ }^{\circ} \mathrm{C}$ em forno de hibridização biometra. Após este período adiciona-se a sonda ( 10 $\mu \mathrm{g} / \mathrm{mL}$ ), previamente diluída em TE (10 mM Tris, $1 \mathrm{mM}$ EDTA) desnaturada a $100{ }^{\circ} \mathrm{C}$ e mantêm-se sob incubação por aproximadamente 12 horas ou uma noite. 
No dia seguinte recolhe a solução contendo a sonda que poderá ser reutilizada. Transfere-se a membrana para um recipiente adequado para as lavagens. A primeira lavagem é feita com uma solução contendo $0.1 \%$ SDS, 1 X SSC sob agitação a $60{ }^{\circ} \mathrm{C}$ por 15 minutos. A segunda é feita nas mesmas condições com uma solução contendo somente a metade da concentração de SSC (0.1\% SDS, 0.5\% SSC).

Após as lavagens a membrana é novamente transferida para o tubo biometra (médio) contendo (15 mL) a solução de bloqueio [Buffer A (10 mM Tris, pH 9,5; $300 \mathrm{mM} \mathrm{NaCl})$ com 1:10 (v/v) líquido de bloqueio] e incubada no forno de hibridização biometra sob agitação a temperatura ambiente por 1 hora.

Após o bloqueio da membrana, despreza-se esta solução e adiciona a solução [Buffer A, 0.5\% (w/v) BSA] contendo o anticorpo diluído na concentração 1:5000 (v/v) e mantêm nas mesmas condições de incubação por mais 1 hora.

Após a incubação com o anticorpo a membrana é novamente transferida para um recipiente adequado para as lavagens de retirada de excesso de anticorpo. Segue-se então três lavagens sucessivas com $250 \mathrm{~mL}\left(\sim 3 \mathrm{~mL} / \mathrm{cm}^{2}\right)$ da solução 0.3\% Tween20 (Amersham Biosciences US 20605) diluída em buffer A, sob agitação a temperatura ambiente por 10 minutos cada. Após as lavagens a membrana é transferida para um filme plástico e cobre-se a superfície da membrana contendo o DNA ligado à sonda conjugada com o anticorpo, com o líquido de revelação CPD-Star [Solução aquosa de [1.5\% (w/v) Disodium 2-chloro-5-(4methoxyspiro[1,2-dioxetane-3,2'-(5'-chloro)-tricyclo[3,3,1,13,7]decan]-4yl)phenyl

phosphate)]. Em seguida outro filme plástico é esticado sobre a membrana que ficará exposta ao líquido de revelação por 5 minutos protegida de luz. Após este período a membrana é transferida para outro filme plástico e embrulha para exposição ao filme de raio-X em cassete apropriados. A exposição ao filme de raio-X é mantida por aproximadamente 24 horas. Após o período de exposição o filme é revelado para visualização dos possíveis alvos identificados.

\subsection{Extração Alcalina do DNA fosmidial (pCC1DNA) [adaptado por Nóbrega M]}

O transformante contendo o clone de interesse é Inoculado em meio LB (20 mL) com adição de clorofenicol (12 $\mu \mathrm{g} / \mathrm{mL})$ e L-arabinose (0,01\%) e incubado em agitador "New Brunswick Shaker” por cerca de 20 horas sob agitação de $300 \mathrm{rpm}$ a $37^{\circ} \mathrm{C}$. Após o período de incubação as células são coletadas por centrifugação a $5000 \mathrm{rpm}$ por 5 minutos a $4{ }^{\circ} \mathrm{C}$. As células precipitadas são lavadas com $10 \mathrm{~mL}$ de água. Em seguida adiciona-se às células lavadas $1 \mathrm{~mL}$ de solução de quebra contendo a enzima lisozima [25 mM Tris-Cl pH 8,0; 50 
mM Glicose; 10 mM EDTA; 2 mg/mL Lisozima; $100 \mu L$ RNAse (10 mg/mL)] e incuba-se a temperatura ambiente por 15 minutos. Adiciona-se $1 \mathrm{~mL}$ de solução alcalina $(0,2 \mathrm{M} \mathrm{NaOH}$, 1\% SDS) agitando-se gentilmente por inversão até que a mistura torne-se translúcida. Então, adiciona-se $1 \mathrm{~mL}$ da solução ácida (3 M NaOAc pH 4,8), novamente agitando-se gentilmente por inversão. A mistura total é submetida à incubação em gelo, por cerca de 10 minutos. Após o período de incubação no gelo a mistura é centrifugada a $6000 \mathrm{rpm}$ por 20 minutos a $4{ }^{\circ} \mathrm{C}$. Coleta-se o sobrenadante ( $2 \mathrm{~mL}$ ) em tubo de vidro “corex” e precipita-se o DNA fosmidial (pCC1DNA) adicionando-se $7 \mathrm{~mL}$ de etanol $100 \%$ e incubando a $-80{ }^{\circ} \mathrm{C}$ por no mínimo 30 minutos. Após incubação a $-80{ }^{\circ} \mathrm{C}$ a mistura é centrifugada a $7000 \mathrm{rpm}$ por 15 minutos a $4{ }^{\circ} \mathrm{C}$. Descarta-se o sobrenadante e resuspende-se o DNA fosmidial precipitado com 1,5 mL da solução (DNA fosmidial $2 \mathrm{M} \mathrm{NH} 4 \mathrm{OAc}$, 0,2 mM EDTA) agitando-se vigorosamente em agitador tipo vortex. Em seguida incuba-se a mistura em gelo por aproximadamente 15 minutos. Após período de incubação a mistura é centrifugada a 7000 rpm por 15 minutos a 4 ${ }^{\circ} \mathrm{C}$. O sobrenadante é cuidadosamente coletado descartando-se o precipitado de proteínas. O DNA fosmidial é novamente precipitado adicionando-se duas vezes e meia (2,5 X) o volume de $100 \%$ etanol e incubando-se a $-80{ }^{\circ} \mathrm{C}$. Após período de incubação a mistura é centrifugada a $7000 \mathrm{rpm}$ por 15 minutos a $20{ }^{\circ} \mathrm{C}$. O sobrenadante é descartado e o DNA fosmidial é resuspendido com 1,5 mL de solução TE (10 mM Tris-Cl pH 8,0; 0,1 mM EDTA). Em seguida a mistura é submetida à extração com fenol (volume/volume) e novamente recuperada por precipitação com etanol 100\% seguido de duas lavagens com etanol $80 \%$. O DNA fosmidial (pCC1DNA) final é secado a vácuo e resuspendido com TE em volume final de $1 \mathrm{~mL}$.

\subsection{Quebra do DNA fosmidial (pCC1DNA) por Nebulização [adaptado Nóbrega M]}

Uma alíquota de aproximadamente $400 \mu \mathrm{L}$ do DNA fosmidial (pCC1DNA) purificado é misturado a $350 \mu \mathrm{L}$ de glicerol $100 \%$ e $250 \mu \mathrm{L}$ de solução TE, totalizando um volume final de $1 \mathrm{~mL}$. Esta mistura é submetida à quebra por nebulização utilizando-se um nebulizador individual da Microban (encontrado em farmácia e modificado no nosso laboratório para este processo). A quebra é processada em quatro ciclos de 50 segundos com pressão de 0,75 $\mathrm{Kg} / \mathrm{cm}^{2}$ (compressor de ar da Fisatan modelo 820) e potência de $300 \mathrm{~W} / 115 \mathrm{~V}$. Após a quebra a mistura contendo os fragmentos de DNA fosmidial nebulizado é coletada $(\sim 800 \mu \mathrm{L})$ em dois tubos de $1,5 \mathrm{~mL}$ ( $400 \mu \mathrm{L} / \mathrm{cada})$ e os fragmentos de DNA fosmidial é precipitado com adição de $100 \mu \mathrm{L}$ de 5 M NH 4 OAc e $1 \mathrm{~mL}$ de Etanol 100\% seguido de incubação a $-80{ }^{\circ} \mathrm{C}$ por 
no mínimo 30 minutos. Após período de incubação a mistura é centrifugada a 13000 rpm por 10 minutos. Os fragmentos de DNA fosmidial precipitados são lavados com etanol 80\% e secados a vácuo. Finalmente os fragmentos de DNA fosmidial são resuspendidos com $50 \mu \mathrm{L}$ de TE e uma alíquota é analisada em gel 1\% agarose. Nas condições relatadas o pCC1_DNAs é fragmentado em fragmentos que variam de 400 pb a 1000 pb.

\subsection{Construção de Biblioteca de DNA fosmidial (pCC1DNA) em Vetor de clonagem pUC18 [Nobrega $M$ et al.]}

Os fragmentos de DNA fosmidial é primeiramente submetidos à reação de reparo das extremidades. Nesta reação utilizamos o kit (DNA polymerase I large (Klenow) - Pharmacia). Para cada $1 \mu \mathrm{g}$ de DNA utilizou-se $1 \mu \mathrm{L}$ da enzima Klenow; $2 \mu \mathrm{L}$ de tampão concentrado (10 $\mathrm{X}) ; 1 \mu \mathrm{L}$ da enzima T4_Kinase e água bidestilada para completar o volume total de $20 \mu \mathrm{L}$. A mistura é incubada à $37{ }^{\circ} \mathrm{C}$ por 30 minutos. Após incubação a mistura é submetida a uma extração (volume/volume) com a solução de fenol/clorofórmio. A fase aquosa ( 20 $\mu \mathrm{L})$ e recolhida e passada em coluna (MicroSpin columns da Amersham). O eluído contendo os fragmentos de DNA fosmidial com as extremidades reparadas é submetido à ligação em vetor de clonagem pUC18 previamente linearizado com a enzima de restrição SmaI e tendo a extremidade 5' desfosfatada com a enzima CIAP - "Calf Intestine Alkaline Phosfatase”. Para a reação de ligação utilizamos o kit "FastLink” da Epicentre com incubação de 2 horas a 20 ${ }^{\circ} \mathrm{C}$.

Ao termino da ligação, a mistura é inserida em E.coli $\left(\mathrm{DH}_{10} \mathrm{~B}\right)$ competente (obtida pelo método químico de tratamento com $\mathrm{CaCl}$ ) por transformação utilizando-se o método de choque térmico. Os transformantes são selecionados através da expressão do gene LacZ em placas de meio LA contendo X-Gal (40 $\mu \mathrm{g} / \mathrm{mL})$ dissolvida em N,N-dimetilformamida $100 \%$ (20 mg/mL).

\subsection{Ensaio de Sensibilidade ao Peróxido de Hidrogênio [adaptado por Bandeira S]}

As linhagens selvagens de Saccharomyces cerevisiae W303 e BY4741 e as linhagens

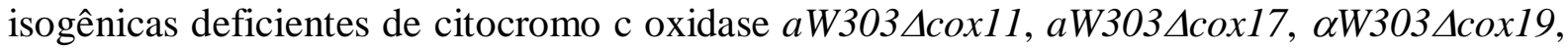
BY4741 $\Delta$ cox23 e $a W 303 \Delta s c o 1$ foram inoculadas em tubos corning (50 mL) contendo $20 \mathrm{~mL}$ de meio mínimo (WO) devidamente suplementado e incubadas por aproximadamente 24 horas a $30{ }^{\circ} \mathrm{C}$ sob agitação de $220 \mathrm{rpm}$. As culturas saturadas foram então transferidas (1:50) 
para novos tubos contendo meio fresco e incubadas por mais 4h, quando o peróxido de hidrogênio (Sigma) foi adicionado em três concentrações distintas (6 mM, $8 \mathrm{mM}$ e $10 \mathrm{mM})$. A cultura foi incubada nas mesmas condições por mais 1 hora ou 2 horas. Diluições seriadas de $10 \mathrm{X}$ foram então espotadas em meio YPD sólido e incubadas por aproximadamente 36 horas a $30^{\circ} \mathrm{C}$. Depois disso a viabilidade das colônias foi comparada com as linhagens não tratadas.

\subsection{Meio Sólido Para Detecção De Siderófero Em Paracoccidioides brasiliensis [adaptado por Bandeira S]}

Para o meio sólido prepara-se uma solução contendo: 5 mM KCl; 7,5 mM NH $4 \mathrm{OAc}$; 8,5 mM NaCl; 1 mM Tris; 10 mM MgSO $4 ; 1$ mM KH $\mathrm{PO}_{4}: \mathrm{K}_{2} \mathrm{HPO}_{4} ; 1 \mathrm{mM} \mathrm{CaCl} 2 ; 0,2 \%$ glicose e 0,3\% casaminoácido, pH final: 5.6, (2\% Agar).

Em um recipiente separado, prepara-se outra solução contendo o corante (CAS) complexado com ferro $\left(\mathrm{FeCl}_{3} \cdot 6 \mathrm{H}_{2} \mathrm{O}\right)$ e HDTMA descrita por Bernhard e Neilands em 1987: (0,73 mg/mL de Hexadecyltrimethyla mMonium Bromide - HDTMA; 0,6 mg/mL Chrome Azurol B - CAS; 1 mM HCl e 0,1 mM FeCl $\left.\mathrm{m}_{3} \cdot 6 \mathrm{H}_{2} \mathrm{O}\right)$. As duas soluções são autoclavadas separadamente e após o resfriamento até $50{ }^{\circ} \mathrm{C}$, são misturadas e distribuídas em placas de petri do tamanho desejado.

Após a polimerização do meio o fungo é inoculado e à medida que for crescendo um halo alaranjado começa a se formar em volta da cultura indicando que o fungo está secretando sideróferos e que estes estão seqüestrando o ferro complexado com o corante (CASFe/HDTMA).

\subsection{Meio Líquido Para Deteç̧ão De Siderófero Em Paracoccidioides brasiliensis [adaptado por Bandeira S]}

Para a detecção de sideróferos em meio líquido, o fungo é crescido em meio líquido (5 $\mathrm{mM} \mathrm{KCl} ; 7,5 \mathrm{mM} \mathrm{NH} \mathrm{N}_{4} \mathrm{OAc} ; 8,5 \mathrm{mM} \mathrm{NaCl} ; 1 \quad \mathrm{mM}$ Tris; $10 \mathrm{mM} \mathrm{MgSO}_{4} ; 1 \mathrm{mM}$ $\mathrm{KH}_{2} \mathrm{PO}_{4}: \mathrm{K}_{2} \mathrm{HPO}_{4} ; 1 \mathrm{mM} \mathrm{CaCl} ; 0,2 \%$ glicose e $0,3 \%$ casaminoácido) sem adição de ferro. Após aproximadamente sete dias de crescimento o sobrenadante da cultura é recolhido por centrifugação, seguido de filtração em seringa.

A detecção é obtida quando misturamos (volume/volume) o sobrenadante com a solução de detecção (Schwyn e Neilands, 1987). 


\subsubsection{Para $100 \mathrm{~mL}$ de solução de detecção}

Um volume de 6 mL de uma solução de 10 mM HDTMA é colocada em uma erlenmeyer de $100 \mathrm{~mL}$ e diluída com um pouco de água. Em seguida adiciona-se 1,5 mL de uma solução contendo ( $\left.1 \mathrm{mM} \mathrm{FeCl} \cdot 6 \mathrm{H}_{2} \mathrm{O} ; 10 \mathrm{mM} \mathrm{HCl}\right)$ e $7,5 \mathrm{~mL}$ de $2 \mathrm{mM}$ de solução de CAS são adicionados sob agitação. Adiciona-se 4.307 gramas de piperazine dissolvida em água e 6,25 mL de $12 \mathrm{M} \mathrm{HCl}$ são adicionados cuidadosamente e o volume é então acertado para $100 \mathrm{~mL}$ total com água. O pH final deve ser de igual a 5,6. Esta solução deve ser mantida protegida de luz. 


\section{RESULTADOS}

O objetivo deste trabalho foi estudar um conjunto de genes nucleares do fungo Paracoccidioides brasiliensis relacionados à expressão funcional do complexo da citocromo c oxidase mitocondrial (COX).

Para identificação dos genes de $P$. brasiliensis utilizamos um banco de dados com aproximadamente 20 mil seqüências de ESTs - "Expressed Sequence Tags” provenientes de projetos de seqüenciamento de genoma (Goldman et al., 2003, Felipe et al., 2003 e Felipe et al., 2005), depositadas no GenBank/NCBI.

A seleção das ESTs de $P$. brasiliensis foi realizada por comparação com as seqüências de polipeptídeos de $S$. cerevisiae que atuam como subunidades estruturais ou participam direta ou indiretamente na montagem e manutenção deste complexo.

Para seleção dos clones de seqüências ESTs de $P$. brasiliensis, com alto grau de similaridade aos genes de Saccharomyces cerevisiae, utilizou-se cerca de quarenta e quatro (44) seqüências de proteína de $S$. cerevisiae como sondas para as buscas in sílico. No processo de identificação dos clones utilizamos a ferramenta TBLASTn do BLAST disponível na página do banco de dados do consórcio paulista disponível em: http://143.107.203.68/pb/frame2.htm, onde contamos com uma réplica do banco de dados do NCBI já disponível publicamente.

No total, identificamos e estudamos dezenove genes de $P$. brasiliensis envolvidos na biosíntese do complexo citocromo c oxidase mitocondrial (Tabela 4). Quase todos os genes estudados foram clonados das bibliotecas de ESTs (Goldman et al., 2003; Felipe et al., 2003), com exceção do gene PbPET191 que foi amplificado diretamente por reação de PCR a partir do genoma nuclear de $P$. brasiliensis e o genes $P b C O X 8$ e PbSCO1 que foram clonados a partir de cDNA sintetizado a partir de RNA total de $P$. brasiliensis. 
TABELA 4: Genes de $P$. brasiliensis Completos com Seqüências Depositadas No GenBank/NCBI

\begin{tabular}{l|l|l|l|l}
\hline Gene S. cerevisiae & $\begin{array}{l}\text { Gene } \\
\text { P. brasiliensis }\end{array}$ & Identidade & Positivos & $\begin{array}{l}\text { Numero de Acesso } \\
\text { no NCBI }\end{array}$ \\
\hline ScCOX4 (155aa) & PbCOX4 (197aa) & $50 \%$ & $69 \%$ & AY603795 \\
\hline ScCOX5A (153aa) & PbCOX5A (204aa) & $36 \%$ & $56 \%$ & AY603790 \\
\hline ScCOX6 (148aa) & PbCOX6 (171aa) & $58 \%$ & $73 \%$ & AY603791 \\
\hline ScCOX8 (78aa) & PbCOX8 (86aa) & $32 \%$ & $47 \%$ & EF681771 - EF988665 \\
\hline ScCOX9 (59aa) & PbCOX9 (62aa) & $30 \%$ & $60 \%$ & AY603792 \\
\hline ScCOX11 (300aa) & PbCOX11 (253aa) & $54 \%$ & $74 \%$ & EF679210 - EF679211 \\
\hline ScCOX12 (83aa) & PbCOX12 (141aa) & $79 \%$ & $87 \%$ & AY603794 \\
\hline ScCOX13 (129aa) & PbCOX13 (142aa) & $37 \%$ & $52 \%$ & DQ003716 \\
\hline ScCOX15 (486aa) & PbCOX15 (491aa) & $50 \%$ & $66 \%$ & DQ003717 \\
\hline ScCOX16 (118aa) & PbCOX16 (135aa) & $39 \%$ & $56 \%$ & AY842443 \\
\hline ScCOX17 (69aa) & PbCOX17 (78aa) & $47 \%$ & $67 \%$ & DQ003718 \\
\hline ScCOX19 (98aa) & PbCOX19 (107aa) & $51 \%$ & $63 \%$ & DQ003414 \\
\hline ScCOX23 (151aa) & PbCOX23 (76aa) & $43 \%$ & $66 \%$ & DQ402182 \\
\hline ScMSS51 (436aa) & PbMSS51 (514aa) & $38 \%$ & $53 \%$ & DQ003715 \\
\hline ScPET100 (111aa) & PbPET100 (103aa) & $42 \%$ & $68 \%$ & AY603796 \\
\hline ScPET112 (541aa) & PbPET112 (603aa) & $31 \%$ & $52 \%$ & DQ402183 \\
\hline ScPET191 (108aa) & PbPET191 (123aa) & $47 \%$ & $67 \%$ & não depositado \\
\hline ScOXA1 (402aa) & PbOXA1 (474aa) & $27 \%$ & $46 \%$ & DQ836715 \\
\hline ScSCO1 (295aa) & PbSCO1 (304aa) & $53 \%$ & $75 \%$ & EF679209
\end{tabular}

A presença de segundo número de acesso do NCBI para os genes PbCOX8 e PbCOX11, refere-se ao depósito da seqüência da região genômica do gene.

Para cada clone identificado, o inserto de cDNA ou de DNA contendo os genes de interesse foram completamente seqüenciados para obtenção da seqüência completa e confirmação da presença da fase aberta de leitura (ORF) - “Open Reading Frame”. Os genes completos foram clonados em vetores de expressão e submetidos a testes de complementação funcional heteróloga em mutantes de $S$. cerevisiae. Obtivemos sucesso em quatro complementações funcionais da função respiratória com os genes PbCOX6, PbCOX17, PbCOX19 e PbOXA1. Estes resultados indicam que os genes acima descritos de $P$. brasiliensis são homólogos aos genes de S. cerevisiae, pois complementam a função respiratória dos mutantes.

Os genes PbCOX8, PbCOX13 e PbPET191 não foram submetidos a teste complementação. O restante dos genes (Tabela 4) embora apresente similaridades significativas não são capazes de substituir a função de seus homólogos em mutantes de $S$. cerevisiae. 


\subsection{Estudo dos Genes de P. brasiliensis}

\subsubsection{PbCOX5A}

Para o estudo deste gene selecionamos o clone referente à EST-VP1-Pb30001-211E08 pertencente ao consórcio paulista (Goldman et al., 2003). Analisando a seqüência completa do inserto deste clone através da ferramenta ORFfinder do NCBI identificamos a região codificadora (ORF- Open Reading Frame) completa do gene PbCOX5A que codifica para uma proteína constituída de 204 resíduos de aminoácidos (AY603790). A comparação da seqüência protéica da $\mathrm{PbCox} 5 \mathrm{Ap}$ com as seqüências desta proteína de outros organismos pode ser observada na figura 1. Há regiões bem conservadas entre os diversos organismos entretanto existe uma extensão da porção $\mathrm{N}$-terminal somente nas proteínas de $P$. brasiliensis e de A. nidulans. Outra diferença que pode ser significativa é a ausência de um bloco bem conservado de oito resíduos de aminoácidos (SEGYSGKG) na porção C-terminal somente das proteínas Cox5Ap e Cox5Bp de $S$. cerevisiae. Em S. cerevisiae a proteína Cox5Ap possui uma homóloga que é a $S c C o x 5 B p$. Embora $S c C o x 5 A p$ seja preferencialmente expressa, na ausência dessa, a ScCox5Bp é capaz de sustentar cerca de 12 a 15\% da capacidade respiratória do mutante de ScCox5Ap (Trueblood e Poyton, 1987).

A análise da seqüência de DNA deste gene, através da ferramenta nebcutter disponível na página da New England Biolabs (www.neb.com), indicou ausência de sítios de restrição apropriados para a excisão da ORF direcionada para a construção do novo recombinante em vetor apropriado para expressão em S. cerevisiae. Portanto, oligos iniciadores específicos foram sintetizados para amplificação da região da ORF e inserção dos sítios de enzimas apropriados (SacI e PstI nas extremidades 5' e 3' respectivamente). Os oligos foram desenhados utilizando-se a ferramenta Primer Select do programa DNASTAR, Inc. Após a reação de amplificação por PCR da região da ORF, o produto de PCR foi digerido com as mesmas enzimas, isolado em gel 1\% agarose eletroeluido e purificado por precipitação com etanol. O fragmento SacI/PbCOX5A/PstI foi ligado (reação descrita em Material e Métodos) no vetor de expressão em S. cerevisiae pMGL3 (Fig. 2) previamente linearizado com as enzimas SacI e PstI e tendo as extremidades 5' desfosforiladas com a enzima CIP- Calf Intestine Phosphatase. A mistura de ligação foi então inserida por transformação em E.coli $\mathrm{DH}_{10} \mathrm{~B}$ competente. Coletamos nove transformantes aleatoriamente para extração dos pDNAs que foram analisados por digestão enzimática e por seqüenciamento confirmando a presença do gene. O clone selecionado ( $p M G L 3 / P b C O X 5 A$ ) foi utilizado no ensaio de complementação 
heteróloga no mutante de $S$. cerevisiae aBY4741 $\triangle$ cox $5 a / M L H U$. A transformação foi realizada pelo método de LiOAc e os transformantes foram selecionados em meio específico (meio mínimo WO suplementado) e testados quanto à capacidade de restauração da capacidade respiratório do mutante em meio com fonte de carbono não fermentável etanol/glicerol. Após incubação a $30{ }^{\circ} \mathrm{C}$ por período apropriado verificamos que este gene PbCOX5A de $P$. brasiliensis não foi capaz de restaurar a capacidade respiratória do mutante aBY4741 $\triangle$ cox5a/MLHU de $S$. cerevisiae mostrando que embora haja similaridade entre as proteínas de $P$. brasiliensis e $S$. cerevisiae (36\% de identidade e 56\% de positivos - Tabela 1) a $P b C o x 5 A p$ não é ortóloga a proteína $S c \operatorname{Cox} 5 A p$. 


\section{COX5A}
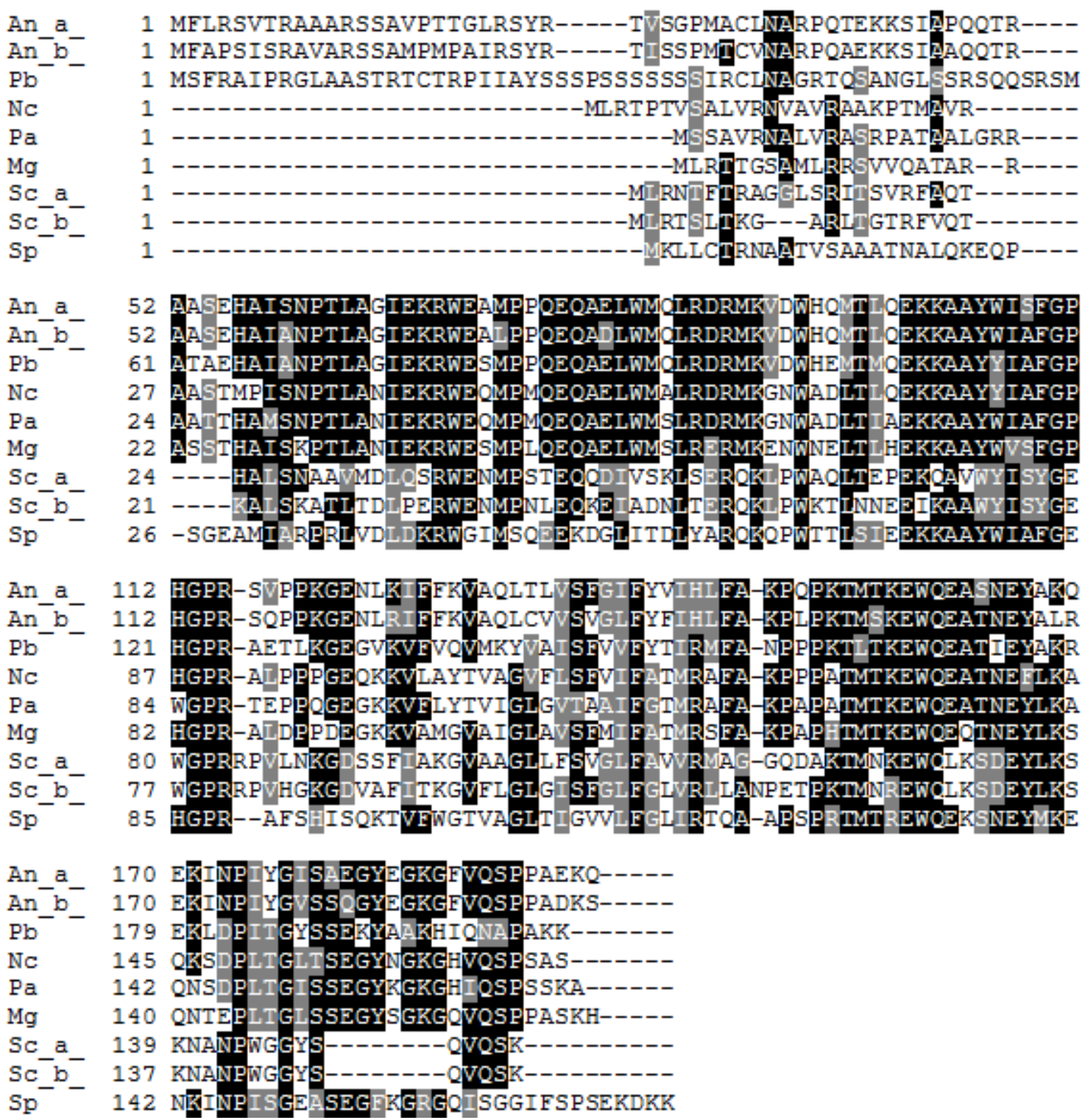

FIGURA 1: Alinhamento da PbCox5Ap de P. brasiliensis ( $\mathrm{Pb}$ ) com as proteínas homólogas.

de Aspergillus nidulans (An), Magnaporthe Grisea (Mg), Podospora anserina (pa), Neurospora crassa (Nc), Schizosaccharomyces pombe (Sp) e Saccharomyces cerevisiae (Sc). An_a e Sc_a representam a seqüência da Cox5ap de A. nidulans e S. cerevisiae, respectivamente enquanto que An_b e Sc_b, a seqüência da Cox5bp. 

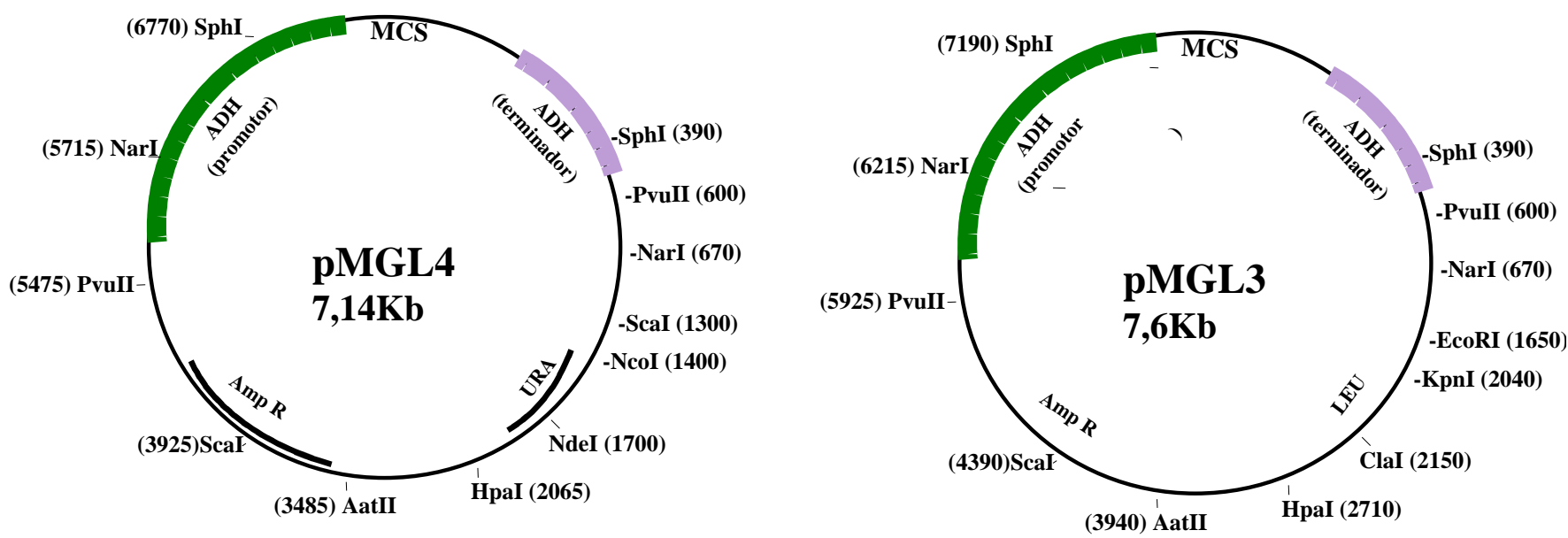

FIGURA 2: Vetores de expressão em Saccharomyces cerevisiae.

Os vetores de expressão pMGL3 e pMGL4 foram construídos a partir dos vetores "ponte” YEp351 e YEp352, respectivamente, com inserção do promotor e terminador do gene de alta expressão em levedura ADH1 (Álcool desidrogenase). Estes vetores foram construídos pela Dra. MOIRA GLERUM da Universidade Alberta no Canadá.

Uma análise quàn à presença de resíduos característicos de hélices transmembrana indica que a proteína $P b C O X 5 A$ de $P$. brasiliensis, possui cerca de sete resíduos de aminoácidos característicos de região de hélice transmembrana (Fig. 3A) o que pela ferramenta utilizada, não foi suficiente para a predição de uma hélice transmembrana (existente na proteína homóloga de $S$. cerevisiae). Entretanto, Analisando a seqüência da proteína ScCox5A de S. cerevisiae a região correspondente (Fig. 3B) corresponde a uma hélice transmembrana. Esta observação sugere que a proteína de P. brasiliensis possa não ser capaz de se inserir corretamente na membrana mitocondrial o que poderia justificar a incapacidade de complementação funcional heteróloga. 
A

\# $\mathrm{Pb}$ Length: 204

\# Pb Number of predicted TMHs:

\# Pb Exp number of AAs in TMHs: 7.55778

\# Pb Exp number, first 60 A.A.s: 0.00047

\# Pb Total prob of $\mathrm{N}$-in: 0.19705

$\mathrm{Pb}$ TMHMM2.0 0 outside 1204

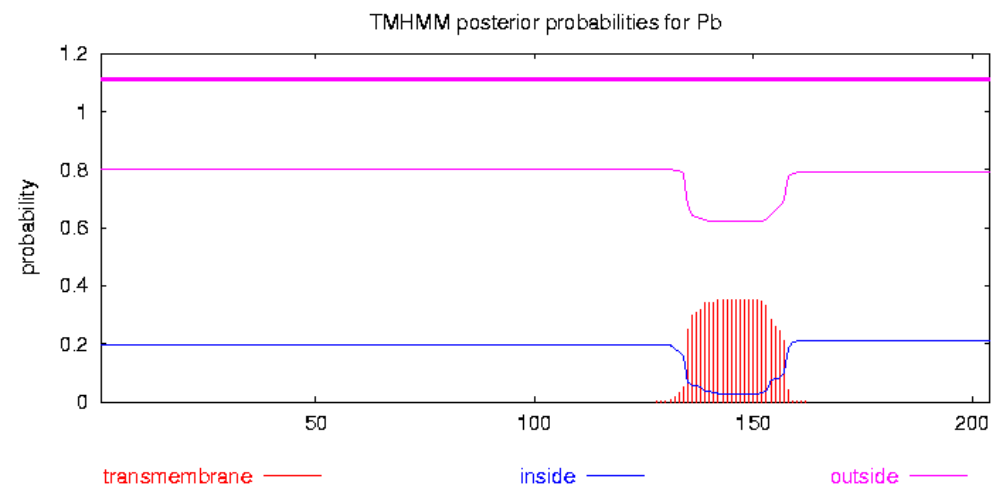

B

* Sc_a_ Length: 153

\# Sc_a_ Number of predicted TMHs:

* Sc_a Exp number of AAs in TMHs: 20.96889

Sc_a Exp number, first 60 AAs: 0.01263

* Sc_a Total prob of $\mathrm{N}-\mathrm{in}$ : 0.69999

Sc_a_ TMHMM2.0 inside 1 92

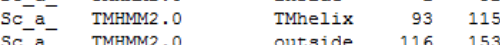

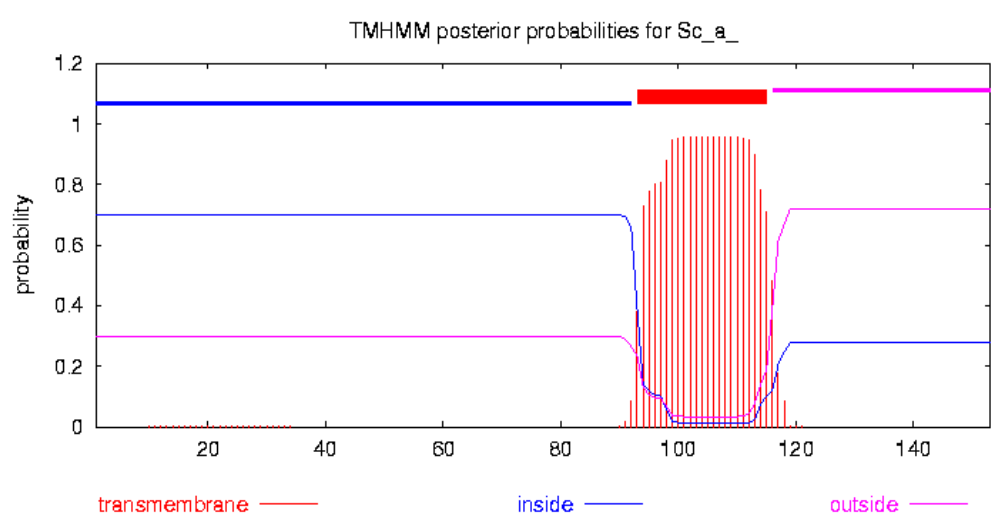

FIGURA 3: Análise de resíduos característicos de hélices de transmembrana na PbCox5Ap. obtida a partir da ferramenta TMHMM Server v. 2.0 disponível na página http://www.cbs.dtu.dk/services/TMHMM/. 3B: Refere-se à mesma análise com a proteína ScCox5Ap de S. cerevisiae. 


\subsubsection{PbCOX6}

Para os estudos deste gene de $P$. brasiliensis escolhemos o clone referente á ESTRC2-PbNEW1-155A05 cuja seqüência protéica predita (AY603791) apresenta cerca de 70\% de similaridade à proteína de $S$. cerevisiae (Tabela 4). O clone referente a esta seqüência de EST pertence à biblioteca do consórcio paulista (Goldman et al., 2003). A partir do seqüenciamento completo e obtenção da seqüência total do inserto deste clone, a seqüência protéica foi comparada à seqüência da proteína Cox6p de $S$. cerevisiae utilizando-se a ferramenta BLASTx do NCBI. Esta análise confirmou sua identidade (58\%) e similaridade (73\%) com a seqüência da ScCox6p de S. cerevisiae (Tabela 4). A análise através da ferramenta ORFFinder identificou uma ORF com 171 resíduos aminoácidos referente a PbCox6p de $P$. brasiliensis. O mapa físico de restrição obtido a partir de analise com a ferramenta nebcutter da New England Biolabs indicou os sítios para as enzimas SacI e XbaI como apropriados para a realização da excisão da ORF direcionada à construção do recombinante deste gene no vetor de expressão pMGL3 de $S$. cerevisiae. Os recombinantes selecionados após transformação em E.coli $\mathrm{DH}_{10} \mathrm{~B}$ foram confirmados por dupla digestão com SacI/PstI e por seqüenciamento. O recombinante selecionado $p M G L 3 / P b C O X 6$ foi inserido por transformação no mutante deficiente respiratório de S. cerevisiae (aW3O3Acox6::URA) e os transformantes selecionados foram testados quanto à capacidade de restauração da função respiratória. Após aproximadamente 48 horas de incubação a $30{ }^{\circ} \mathrm{C}$ verificamos o crescimento comparável ao da linhagem selvagem (Fig. 4) em meio de cultura com fontes de carbono não fermentável (EG) indicando que a proteína PbCox6p de $P$. brasiliensis é capaz de restaurar a capacidade respiratória do mutante $a W 303 \Delta$ cox6::URA de $S$. cerevisiae. Este resultado foi confirmado posteriormente através da técnica de transformação reversa ("Back transformation”) onde o recombinante (vetor::gene) é extraído da linhagem recombinante competente respiratória é novamente testado em complementação heteróloga, confirmando ser este o agente da complementação funcional.

A ScCox6p de S. cerevisiae codifica para a subunidade VI da citocromo oxidase e é constituída de 148 resíduos de aminoácidos, portanto em P. brasiliensis esta proteína é acrescida de 23 resíduos de aminoácidos (total 171aa) sendo que a maioria deles estão na região N_terminal da proteína (Fig. 5). Embora haja esta inserção de aminoácidos nesta região, a proteína de $\mathrm{P}$. brasiliensis contém a maioria dos resíduos de aminoácidos conservados nos outros fungos analisados (Fig. 5) o que provavelmente favorece o 
endereçamento correto da proteína para a mitocôndria. Além disso, o restante da proteína apresenta um alinhamento homogêneo com as proteínas homólogas.

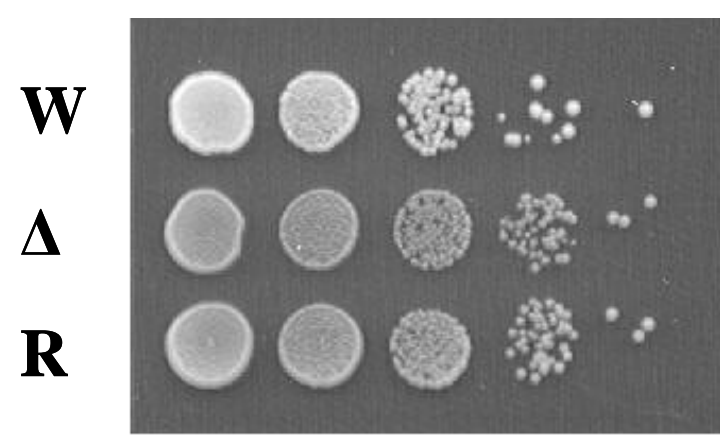

YPD

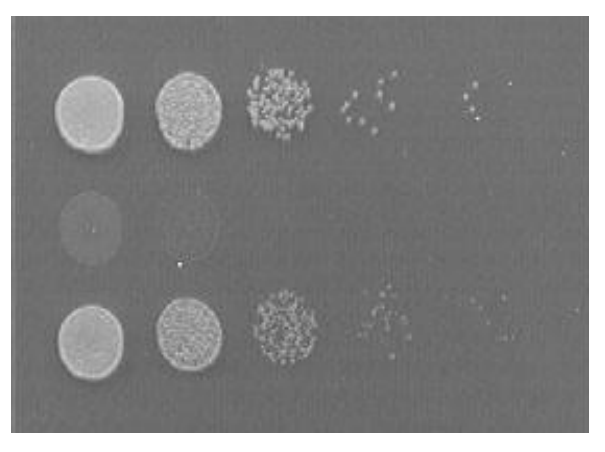

EG

FIGURA 4: Complementação funcional heteróloga do gene PbCOX6 no mutante de $S$. cerevisiae. Crescimento das linhagens selvagem (W), mutante deficiente respiratório de S. cerevisiae com deleção do gene COX6 [COX6aW3O3 $\Delta$ cox6::URA $(\Delta)$ ] e o recombinante aW3O3 $\Delta$ cox6::URA/ pMGL3/PbCOX6 (R) em meio de crescimento YPD e em meio contendo etanol/glicerol (EG) após 48 horas de incubação a $30^{\circ} \mathrm{C}$. 


\section{$\operatorname{cox} 6$}

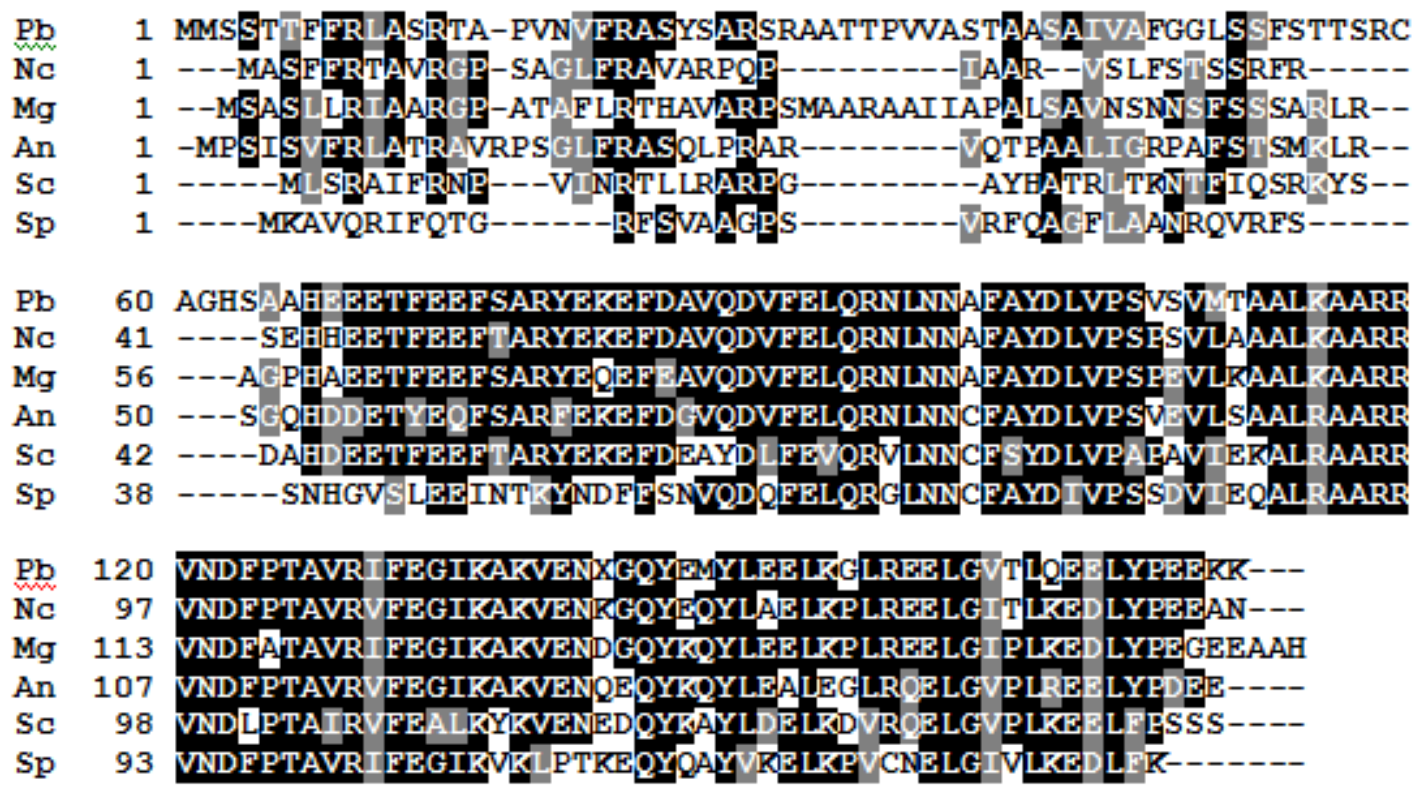

FIGURA 5: Alinhamento da PbCox6p de $P$. brasiliensis (Pb) com as proteínas homólogas. de Aspergillus nidulans (An), Magnaporthe Grisea (Mg), Neurospora crassa (Nc), Schizosaccharomyces pombe (Sp) e Saccharomyces cerevisiae (Sc).

A análise da seqüência protéica da proteína $P b \operatorname{Cox} 6 p$ quanto a presença de uma região característica de aminoácidos de hélice transmembrana indica uma certa quantidade destes resíduos característicos (aminoácidos em hélices de transmembrana) nos primeiros 60 resíduos de aminoácido da proteína $P b C o x 6 p$ (Fig. 6) entretanto, a predição deste tipo de aminoácido na região N-terminal pode ser uma indicativa de um peptídeo sinal e não de uma hélice transmembrana. Esta observação sugere que os resíduos excedentes encontrados na região N-terminal da proteína de $P$. brasiliensis em relação à proteína de $S$. cerevisiae (Fig. 5), constituiriam uma porção de peptídeo sinal desta proteína e que seria então retirada no processo de importação para a mitocôndria. 

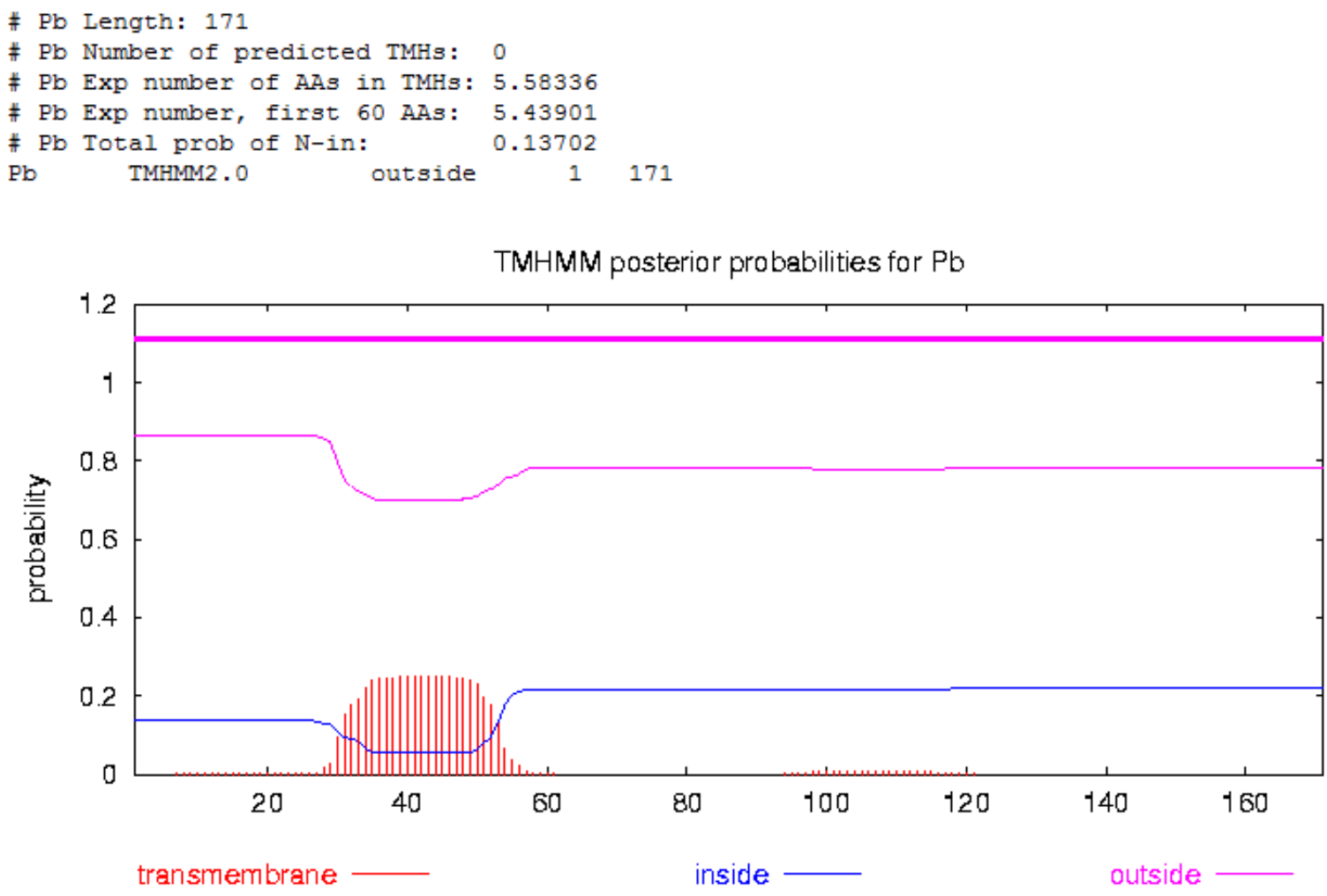

FIGURA 6: Análise de resíduos característicos de hélices de transmembrana na PbCox6p. obtida a partir da ferramenta TMHMM Server v. 2.0 disponível na página http://www.cbs.dtu.dk/services/TMHMM/.

\subsubsection{PbCOX8}

Usando a proteína ScCox8p de Saccharomyces cerevisiae, identificamos no banco de dados de Paracoccidioides brasiliensis a EST018969 depositada do GenBank/NCBI sob o numero de acesso CN253032 referente ao isolado Pb01 (Felipe et al., 2003). A nálise por BLAST-x indica que a seqüência da EST018969 apresenta 30\% de similaridade na porção do alinhamento com a seqüência da proteína Cox8p de $S$. cerevisiae.

Utilizando a seqüência da EST018969 para uma nova busca no banco de dados identificamos um clone de DNA genômico de P. brasiliensis RST-VP1-Pb30003-012G11 (pertencente a uma biblioteca construída Nobrega, M e colaboradores) contendo uma região de aproximadamente quarenta nucleotídeos com 90\% identidade à EST018969, correspondente ao gene $\mathrm{PbCOX} 8$. Este clone de DNA genômico foi isolado e totalmente seqüenciado utilizando-se a técnica de inserção de transposons descrita em material e métodos, obtendo-se um consenso com aproximadamente 1971bp. A região codificadora do 
gene PbCOX8 (fase aberta de leitura - ORF) foi identificada na porção central do fragmento. O gene $\mathrm{PbCOX8}$ está interrompido por dois íntrons como pode ser observado na figura 7. As seqüências dos íntrons, bem como os motivos canônicos de borda intrônica [(5’ GT...AG 3’ (Reinoso et al., 2005)], também podem ser observados na Fig. 7. A seqüência nucleotídica e a seqüência predita da proteína foram depositadas no GenBank/NCBI sob o número de acesso EF988665.

\begin{abstract}
$>\mathrm{PbCOX} 8$
ATGTTGTATAAGACGACAGTCTCCCGCCGTATTAGAACCATCCTTCACAAGCCCATTTGACTGTCTCTTTCTG CTCTTGTCCTTCTTGGCTCGAGGTTTGGGGGCTCCTTGAGGAGGAATTCCTGA_AAGGGGTTTATCCTCA.AACA CATTGAACAGATCGTCCATGTTGGGTAGACAGTCCACTGAAATCCCTTTTAATTCCTCCGACGCTGCGTTGTG GAAAGTCTCCAGCTGCATCTATATACAACTCTTTATGCGACTAAGTTTGTTTAAAATTGTCAAAATTGCATCG GCGA_ACTCTCCCGATAAGGTTTCTCCGATTCGTATTGGCTGGGAGCTAGTTATATCACGTGTTATGGACTCA GGCTGAGTCAGCAAGAGTTGCCCAACTAACGTCCCGAGGAGTTCAAGAGACATTCTTCTGTATATTCCCGTCT ACGACACAACTCCAAGTCAATTCTGCCTCGACAGCATCCTAAAGGTACGGGCTAGTCCCTAGTGGCATCAGTC CGCTCAGTCTGTTGCTAACTGGCCGTTCAAGATGATCGCTCAAACCGCAACCCGTGCCAGAATGGCCACCACC ATTGCCCGCCGTGGCCTCCACTCCTCCCGCCCGCAGATGGCCAGTCCTTTCCATTACCCAGAGGGCCCTCGCT СTAATCTCCССTTTAATCCTTTGACGAAGTATTTCTTCTTGAGATATTGGGGCTTTGTGGGTAAGTAGGAATT TCTCCGAATTATGTGGCCACTATTCGATTGCTGACAACTTGTAGCTGTTGGTTTCGGCGCTCCCTTCGCTATT GCTGGTAATACTTAAACCCAATGTACCATCATATATGTGCAGTGAAACACCACTAATACAATGATAAACAGTC TGGCAAACTAAGAAAACCCAAGTAAACGTGTTGGCAAGTTTATTTATTTGATCTGGACCGTGGTGATGTGACA AGGAAGATGTTCTTTAAAGTTCACATAGGTTGTTTGTTTGACTTTGTAATGTGTATATACATAGTTGCGGAGC TAGA_ATACCATAAAGTCAAAATCTCCCATGTTGCCATAGCTAGATATGTGTAAATTGCAAAATATTGTATGG TGGGTGCTGTATTAGACTATTTTATAAGGAGTTTTGTGTTGGTTCAGCCAGTTCATGGATGCAGAAAAAACTT GTTACTCACCCCAAAAGAAAAATTGAGAAGCACATTTATTTATTTCACCTTCGCTTGAATTACATCTATCCCA ACCAACAACTCCATAATAGACTATGACGCCGTCGCCTTAAAATACCAGACTGTATGGGATAGTATTTAAAATA A.AAGGTGTTCTCGA_ACCTAGGTACAGCGCATACGGTCAATATAAAATGCGCAATTTGAGGAACATACACCTG CGCGAGACTCCGCTTGGGGGGGAGCTGCCTCTGACTGCAACGGCATGGGATCCTGTGACGGATTCCATCCTTT GCACATTTGGGCCAACGGA_AACAAGTGCTGTCATTGAACTGA_ACGAAAAGTGCAGGATGCAAACGAGGAGGC GGAGGATATCCAGTTGATCACCTCTTGGGATGCACCATGTCCGCTCCCAGATTTGCAACATGACAGAGTTTTA TCATTGCAATATTTTGCAGATACTTTAGTTACATGCCTTGTGTTAGAAGGCGGTGATATCATAGTTGTGCGTG AAGACCCCCAACCGGGCGAGGACAAAATTGAAATCGTGGGGTCAGTTGACGTGGGAATTACAGCAGCGGCATG GTCTCCGGATGAAGAGCTACTTGCAGTCACCACCAGGTCCAACACACTTCTCTATATGACAAGGGATTTCGAA AATGTGGCCAACATTGCATTCACAAGCGACGATCTCAAGGCGTCAAGACATGTTTCTGTTGGCTGGGGAAAAA AgGAGACACAGTTTCAGgGCAAGAGAgCAAAAgCTCTGAGGGACCCGACGATA
\end{abstract}

FIGURA 7: Análise da seqüência consenso da RST-VP1-Pb30003-012G11.

Indicando a região codificadora do gene $P b C O X 8$ de $P$. brasiliensis na posição mais central do fragmento. Na porção C-terminal pode se observar uma região N-terminal de outra proteína hipotética de P.brasiliensis. 
Para obtenção da seqüência expressa (cDNA) deste gene e confirmação da localização dos íntrons, sintetizamos um par de oligos específicos ([Forward: 5'GGGCTAGTCCCTAGTGGTACCAGTCCGCTCA R e R'CCTATGTGAACTTTCTAGAACATCTTCCTT]) para amplificação do gene $P b C O X 8$ a partir de cDNAs Poli(T). Obtivemos um produto de PCR com aproximadamente 369bp que foi clonado em vetor TOPO TA Cloning/Invitrogen. Por seqüenciamento do fragmento amplificado, identificamos a fase aberta de leitura para a proteína $P b C o x 8 p$ contendo 86 resíduos de aminoácidos. Esta análise confirma o resultado predito da seqüência genômica e a confirmação da presença e localização dos íntrons. Esta seqüência encontra-se depositada sob o numero de acesso EF681771. O produto constituído por 86 resíduos de aminoácidos possuiu uma região característica de aminoácidos em hélices de transmembrana entre os resíduos 49 e 71 (Fig. 8) e estima-se que a proteína predita tenha uma massa de aproximadamente 9689.34 Daltons.
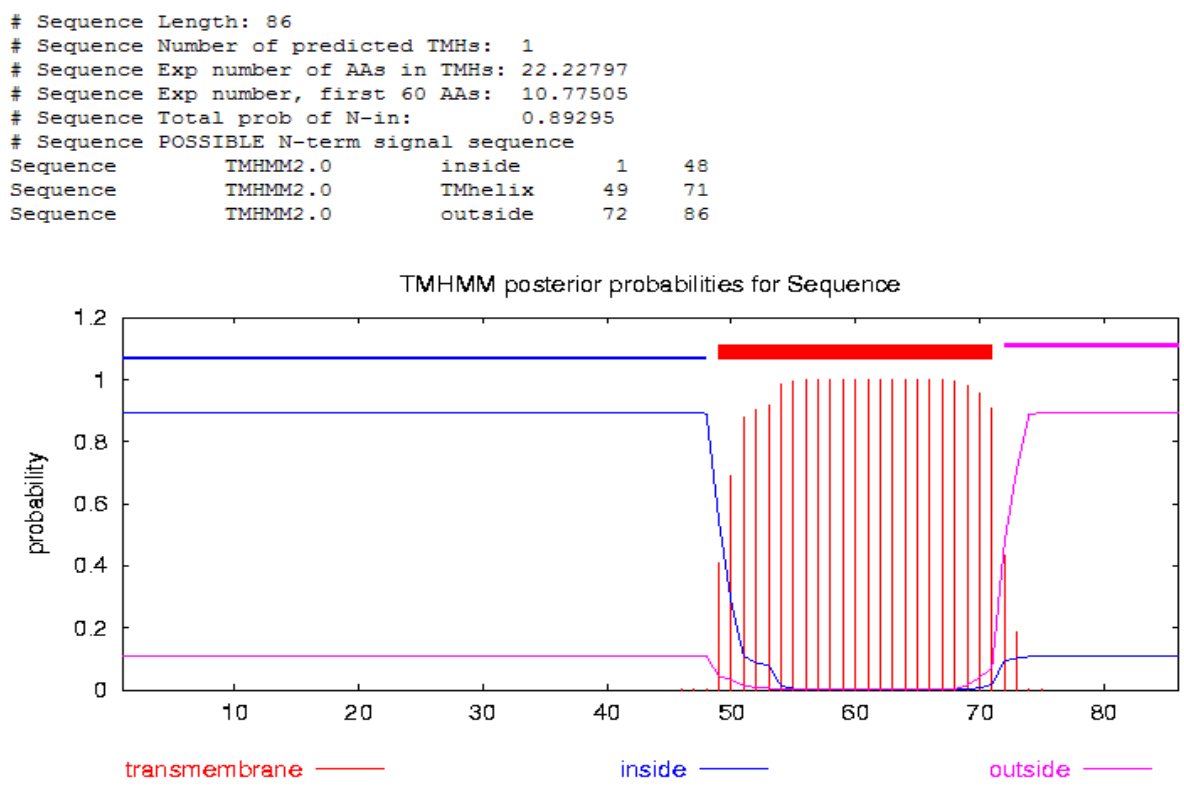

FIGURA 8: Análise de resíduos característicos de hélices de transmembrana na PbCox8p. características obtida a partir da ferramenta TMHMM Server v. 2.0 disponível na página http://www.cbs.dtu.dk/services/TMHMM/. 
Os estudos com este gene não foram concluídos faltando ainda realizar a transferência do fragmento de cDNA contendo a região codificadora (ORF) para vetor de expressão em $S$. cerevisiae e o ensaio de complementação funcional heteróloga no mutante específico deste gene na levedura.

Na porção 3' do fragmento genômico seqüenciado (Fig. 6) pode-se observar o inicio de uma outra região codificadora que por comparação de seqüências observamos alta similaridade com a proteína AFUA_4G07140 “killer toxin sensitivity protein” (IKI3), putativa [Aspergillus fumigatus Af293].

A subunidade VIII da citocromo c oxidase foi inicialmente identificada por Power et al., 1984 que descreveu a seqüência polipeptídica da proteína Cox8p de Saccharomyces cerevisiae e também propôs um modelo para sua estrutura secundária. Devido à presença de uma região central altamente hidrofóbica estes autores sugerem que estes resíduos façam parte de uma região transmembrana da proteína Cox8p. A análise da seqüência proteíca identificada como PbCox8p também indica a presença de uma região transmembrana corroborando nosso resultado (Fig. 8). Power et al., 1984 também destacam que a proteína ScCox8p possui uma região carboxiterminal com dupla lisina, fato que é confirmado quando Patterson e Poyton (1986) resolvem a estrutura genômica do gene ScCOX8 de S. cerevisiae. Neste trabalho os autores demonstram por comparação da seqüência predita a partir da seqüência nucleotídica, com a seqüência da proteína ScCox8p (Power et al., 1984), que esta proteína assim como outras proteínas mitocondriais, codificadas no genoma nuclear, possui um peptídeo sinal de endereçamento mitocondrial. Além disso, a $S c C o x 8 p$, assim como as subunidades VI e VIIa do complexo da citocromo c oxidase, é processada em ambas as extremidades e portanto em S.cerevisiae a $S c C o x 8 p$ é derivada de uma precursora maior sendo estendida por um peptídeo líder na região N-terminal com aproximadamente 22 a 27 resíduos e por um peptídeo trailer, com 4 resíduos, que se estende após o potencial sítio de clivagem lys-lys-COOH que constitui a região carboxiterminal identificado no seqüenciamento da proteína (Power et al., 1984). Na proteína PbCox8p também podemos identificar o sítio de dupla lisina (KK) (Fig. 9) na região C-terminal sugerindo que em P.brasiliensis este processamento C-terminal também existe e que portanto, sua porção Cterminal também possa ser dependente do processamento de uma protease.

A subunidade VIII do complexo da citocromo c oxidase é requerida para o nível máximo da respiração e da atividade da citocromo c oxidase entretanto, mutantes desta subunidade ainda são capazes de crescer em meio com fontes de carbono não fermentáveis como etanol e glicerol (Patterson e Poyton,1986). 


\section{$\operatorname{cox} 8$}

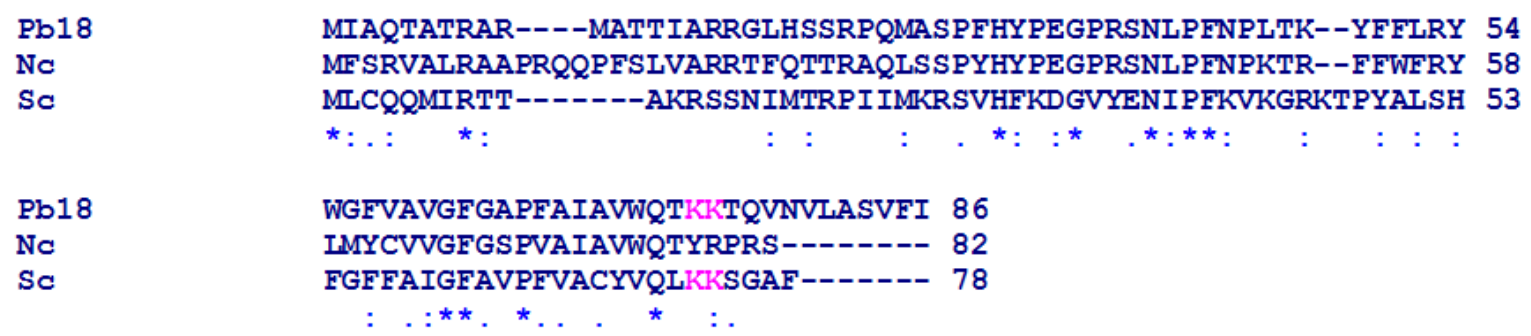

FIGURA 9: Múltiplo alinhamento das seqüências das proteínas Cox8p de do isolado Pb18 com as homólogas. Neurospora crassa $(\mathrm{Nc})$ e Saccharomyces cerevisiae $(\mathrm{Sc}) .\left(^{*}\right)$ significa que todos os resíduos são iguais na coluna; (:) significa que existe substituição conservada em algum resíduo na coluna e (.) significa que existe a substituição semiconservativa em alguns resíduos da coluna. A ferramenta ClustalW está disponível em http://npsa-pbil.ibcp.fr/cgi-bin/npsa_automat.pl?page=/NPSA/npsa_clustalw.html. Em lilás pode-se observar o duplo resíduo de lisina (KK) na região carboxiterminal. Estes resíduos são preditos como sitio de atuação de protease durante o processamento e importação da proteína Cox8p para a mitocôndria.

\subsubsection{PbCOX11}

Para o estudo do gene PbCOX11 de Paracoccidioides brasiliensis identificamos o clone de EST-RC2-Pb30001-153C08, pertencente ao consorcio paulista (Goldman et al., 2003) entretanto, não foi possível obtermos este clone no banco de origem. Em uma nova análise utilizando como sonda a seqüência do inserto do clone da EST-RC2-Pb30001-153C08 depositada no banco de dados para uma nova análise de comparação com o banco de dados de seqüências de $P$. brasiliensis, identificamos um clone de seqüência genômica (RST-RC2Pb30004-018D01) da coleção de RSTs -Random Sequence Tags (Nobrega, M e colaboradores), ainda não depositada em banco de dados publico. Esta seqüência apresentou um excelente alinhamento com 100\% de homologia com a seqüência da EST sugerindo que este clone representava um fragmento genômico de $P$. brasiliensis contendo o gene PbCOX11.

O clone RST-RC2-Pb30004-018D01 foi inteiramente seqüenciado utilizando-se a técnica de inserção de transposons. Obtivemos um consenso com aproximadamente 2800bp. O gene PbCOX11 está inteiro neste fragmento genômico que se encontra depositado no GenBank/NCBI sob o numero de acesso EF679211. A comparação de seqüências entre o consenso da seqüência genomica e a seqüência da EST RC2-Pb30001-153C08 demonstrou claramente a presença de três íntrons neste gene (Fig. 10). A seqüência dos íntrons, bem como os motivos canônicos de borda intrônica [(5’ GT...AG 3’ (Reinoso et al., 2005)] também podem ser observados na Fig. 10. Além do gene PbCOX11 outra fase aberta de leitura esta presente neste fragmento e a proteína predita possui alta similaridade com a subunidade C de 
um fator de replicação Rfc5 de DNA. A região intergênica entre esta proteína e a proteína PbCox11p consiste de aproximadamente $0,5 \mathrm{~Kb}$.

\begin{abstract}
$>\mathrm{PbCOX} 11,018 \mathrm{D} 012804 \mathrm{bp}$
GATCCT CACTITGGAGCCTAGGCTTCCCATTIT GGAGCCTAGGCTTCCCATTACA GACTAGCCACCGCACAGTAGTTTATACCGA GA TAGCT ACCAAIACAACCA.ATTCA GACGTCTCACAGATTGTTTCTGCGCCCAACGAGCCGAGTCACGTGAAAICTCACCCGATCCGGATTGATTGCAI CGA.ACACTTCTCTCAATGAGCTTTGTTCAATCTAATTTCACACCTCCGCACATATCGAGTTACTA

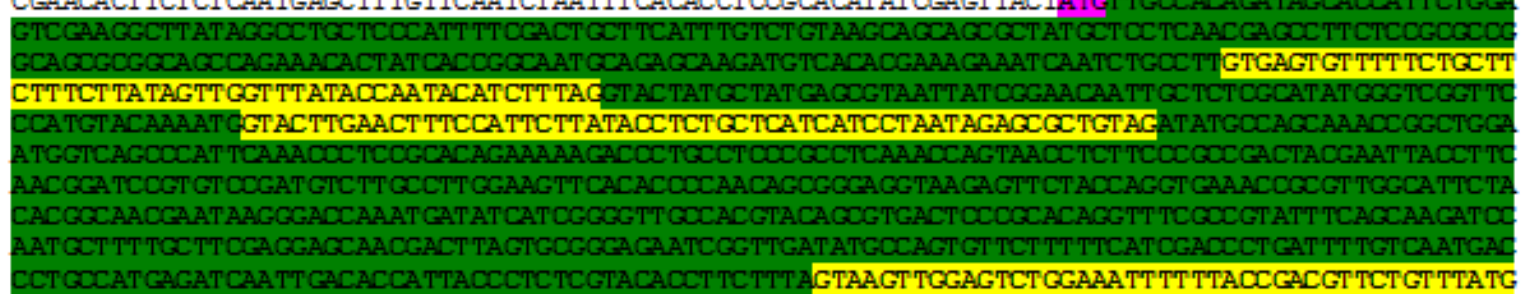

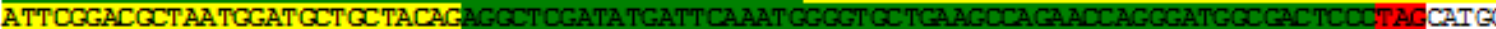
CCTTAATTATTTGCGCGAGGGACAGCGTCCAACTTGCGTAGTGATTTCCACGAAACTTTGGCTTTTGGGGGCAATATCTCTATTTCCGTCAT TCGGGGAT GAGCAATAAAACGTCACTTATTATACATGGGGGGGTGATAAGTGTCCCATTTCAGACACATTTGATCTCTCTGTGCGCTCCATC CTAAAT GGCAATT GAGCCCATTTCGTTCAATCT TCACTCAAACACTTCAGAACCATCGACTTGTT TCCGGGCAGGCTCAAGAGCTATATATA GAA_ACTCATTTTGGAATGGAGCGGA_ATGAATCTCTGTGTTTCTTATATATATTGCATTTTATATCTAGGCGTGGTTTTGATCAAGCAGAT TCAACCTGGGGCATGGTATGTGGCGTTCTTGGGAAATTACTTATTTCTAGAATCATAAATAGCATCACTCATCTCAAAACTATCCTCAGA_AA TAGAATCAAGTCTGAATTTTTTGGTATCTCAAATTTGATAATGGATTTTGCTGCAGTTCCGGCCTCCAAGAGCGGGGAGTAGTCAGCCGGA GCACAGACCACCACTTAAAGTCGCGTGGGGCACGCGCTTTCTTCTTCTCAGGAGACTTTGAATATCAAACCCACCTA_AACAATTCATACGTA TTTTAATT TCA.AACACACCATTTACTACTA_ACA.AT GCCACTTTTAGTT GATAGGCTCCGGCCTAGGAGCCTCGACGCTCTTACCTACCACCG TGAACT TTCCGCTCGACT GAAATCACTTGTGAGCATTATAACTTGGCTCTACATCCTATTATGATATTCATT GCCGGCTGACTATTGGAGCG AATTCACAGGCGCAAAGCGGTGATTTTCCGCACCTTCTGGTTTATGGACCCTCAGGAGCAGGGAAGAAGACAAGAATAATCGCCACGCTGAA GGAACTTTTGGTACTGGTGTCGAA_AGATCAAAATCGACGCTCGAGTCTTCCAA_ACGAGCACCAATCGCAAGTTGGAATTCAACATTGTCT CCTCAGTCTACCACCT TGAAATCACACCATCTGACGTGGGCAATTACGATCGGGTTGTGGTACAGGAACTTCTCA.AGGAGGTTCCCCACACG CAACAGGTCGATCTGTCCGCGAAGCAGCGATTTAAGGTCGTTGTCATCAATGA.AGCAGATCATCTTACGAGAGATGCGCAGGCAGCATTACG A.AGGCTATGGAAAAGTACAGTCCTAATCTGAGAGTTATCTTACTTGCAAACAGCACTGCAAATATCATCGCTCCCATTAGATCCAGARCAC TCCTTGTCAGGGTCGCTGCACCCACTGA_AGCTGAA_ATATGTCAGGTACTA_AAGCTTGCAGGAAAGAAGGAAA_ATTGGGCAGAGGCACCAGGA CTTAATAA_AAGGATAGCCAAAGAGAGTGGACGA.AATCT GAGACGTGCTCTTCTCATGTTCGAAGCTATATATGCCCAGAAGTACGTTGAGTC GGGGCTCCCACAGCTGCAAATACGCAATTTCAACT GACAAGTTTCATTTCCGA_AATAGCGAGA_AAGGACGGATGATACGCCAATTCCACCT CCTGAACTGGGAGGCATTGATCCTGTCTCTTATACACATCTCAA
\end{abstract}

FIGURA 10: Análise da seqüência consenso da RST-RC2-Pb30004-018D01. Indicando a região codificadora do gene $P b C O X 11$ de $P$. brasiliensis e a seqüência dos íntrons, bem como os motivos canônicos de borda intrônica (5’ GT...AG 3’).

Para clonagem do cDNA referente ao gene PbCOX11 foi sintetizado um par de oligos nucleotídeos específicos (senso: 5'- CTAATTTCAGAGCTCCGCACATATCGAGTT e antisenso: 5’- GCCATTTAGGCTGCAGCGCACAGAGAGA) que inseriram os sítios de reconhecimento das enzimas de restrição SacI e Pst1 respectivamente.

O produto da reação de PCR, obtido com a amplificação do gene PbCOX11 partir de cDNAs Poli(T) gerou um fragmento com aproximadamente 911bp. Este fragmento foi clonado em TOPO TA Cloning/Invitrogen. Após o seqüenciamento completo do fragmento de cDNA, identificou-se a fase aberta de leitura referente à proteína PbCox11p contendo 253 resíduos de aminoácidos. A análise da seqüência do cDNA confirmou o resultado predito a partir da análise da seqüência genômica quanto a presença e a localização dos íntrons. Estimase que a proteína predita tenha uma massa molecular de 2,8KDa. A seqüência nucleotídica e da proteína predita a partir do cDNA está depositada no GenBank/NCBI com o número de acesso EF679210. 
O gene COX11 codifica para uma proteína da membrana interna mitocondrial que é essencial para a montagem do complexo da citocromo c oxidase. A maioria dos estudos sobre esta proteína foi realizada em S. cerevisiae entretanto esta proteína é bem conservada entre os organismos incluindo as bactérias, fungos, plantas e animais tendo mais de 300 seqüências de proteínas homólogas depositadas no banco de dados do GenBank/NCBI. A proteína Cox11p está envolvida na incorporação de cobre no centro CuB na subunidade CoxIp e magnésio durante a montagem do complexo da citocromo c oxidase (Tzagoloff et al., 1990; Tzagoloff et al., 1993, Pungartnik et al., 1999; Hiser et al., 2000). O cobre é doado para a proteína Cox11p por ação da proteína Cox17p que também atua no transporte deste elemento para a proteína Sco1p, também envolvida na montagem da COX (Horng et al., 2004). Estudos demonstram que a proteína Cox11p encontra-se ancorada na membrana interna da mitocôndria por um único seguimento transmembrana (Carr et al., 2005). A análise da seqüência protéica da $P b C o x 11 p$ também indica a presença de um domínio transmenbrana (Fig. 11). Esta proteína possui uma topologia conhecida como N “in” C “out”, onde a porção $\mathrm{N}$-terminal está voltada para a matriz mitocondrial e a porção C-terminal que contêm várias cisteinas, metioninas e histidinas capazes de se ligar ao cobre encontram-se exposta no espaço intermembranas, onde forma um homodimero que liga dois íons do Cu (I) (Carr et al., 2002; Carr et al., 2005; Khalimonchuk et al., 2005). Na Fig. 11 podemos observar que a proteína PbCox11p de P.brasiliensis também possui uma topologia predita com uma porção N “in” C “out”. Estas observações corroboram para a caracterização desta proteína de P. brasiliensis. 

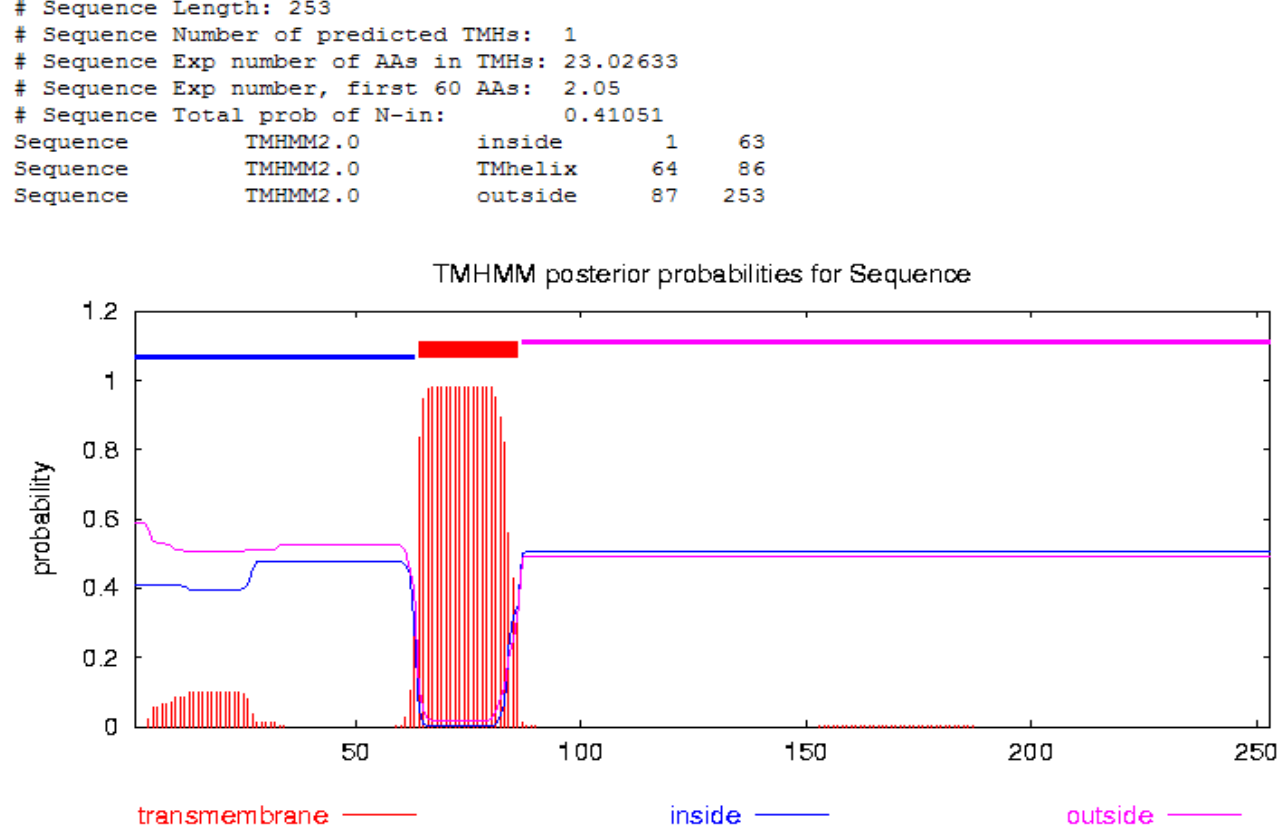

FIGURA 11: Análise de resíduos característicos de hélices de transmembrana na PbCox11p. obtida a partir da ferramenta TMHMM Server v. 2.0 disponível na página http://www.cbs.dtu.dk/services/TMHMM/.

Khalimonchuk e colaboradores em 2005 sugerem que a porção N-terminal da proteína Cox11p interage com os ribossomos mitocondriais mais que esta função na tradução ainda não é clara já que a porção N-terminal não é essencial para a função da proteína Cox11p. Entretanto, a ligação entre a função de Cox11p e o sistema mitocondrial de tradução parece ser conservada entre os organismos, desde que em Schizosaccharomyces pombe também se observa a existência de uma extensão na porção 5' da proteína relativa a Cox11p de $S$. cerevisiae que codifica para uma proteína similar (Rsm22p) às proteínas ribossomais mitocondrial (Carr et al., 2005). Ainda segundo Khalimonchuk et al., 2005 e Banting e Glerum (2006) a Cox11p pode ajudar na incorporação de cobre na subunidade CoxIp de uma maneira co-translacionalmente e que de acordo com esta hipótese, os níveis de CoxIp estariam reduzidos em um mutante nulo de cox11.

O mutante de cox11 é deficiente respiratório e para testarmos a capacidade de complementação funcional heteróloga da proteína PbCox11p de P.brasiliensis no mutante nulo aW303 $\triangle C O X 11:: H I S 3$ de $S$. cerevisiae construímos o recombinante pMGL3/PbCOX11, utilizando-se dos sítios SacI e PstI inseridos nas extremidades 5' e 3' do gene respectivamente na amplificação do mesmo a partir do cDNA poli(T). Este recombinante foi inserido no mutante por transformação utilizando o método de acetato de lítio como descrito em material 
e métodos. Os transformantes foram selecionados em meio mínimo (WO) devidamente suplementado e submetidos ao teste de crescimento em meio contendo fontes de carbono não fermentáveis como etanol e glicerol (EG). Neste ensaio não obtivemos crescimento dos transformantes indicando que embora a proteína $P b C o x 11 p$ de $P$. brasiliensis mantenha alta similaridade de seqüência com a proteína ScCox11p de S.cerevisiae, incluindo similaridade com a região característica de hélice transmembrana e a região do domínio ligante de cobre (Fig. 12) essencial para a função da proteína, a $P b \operatorname{Cox} 11 p$ não é capaz de substituir a função homóloga neste organismo. 


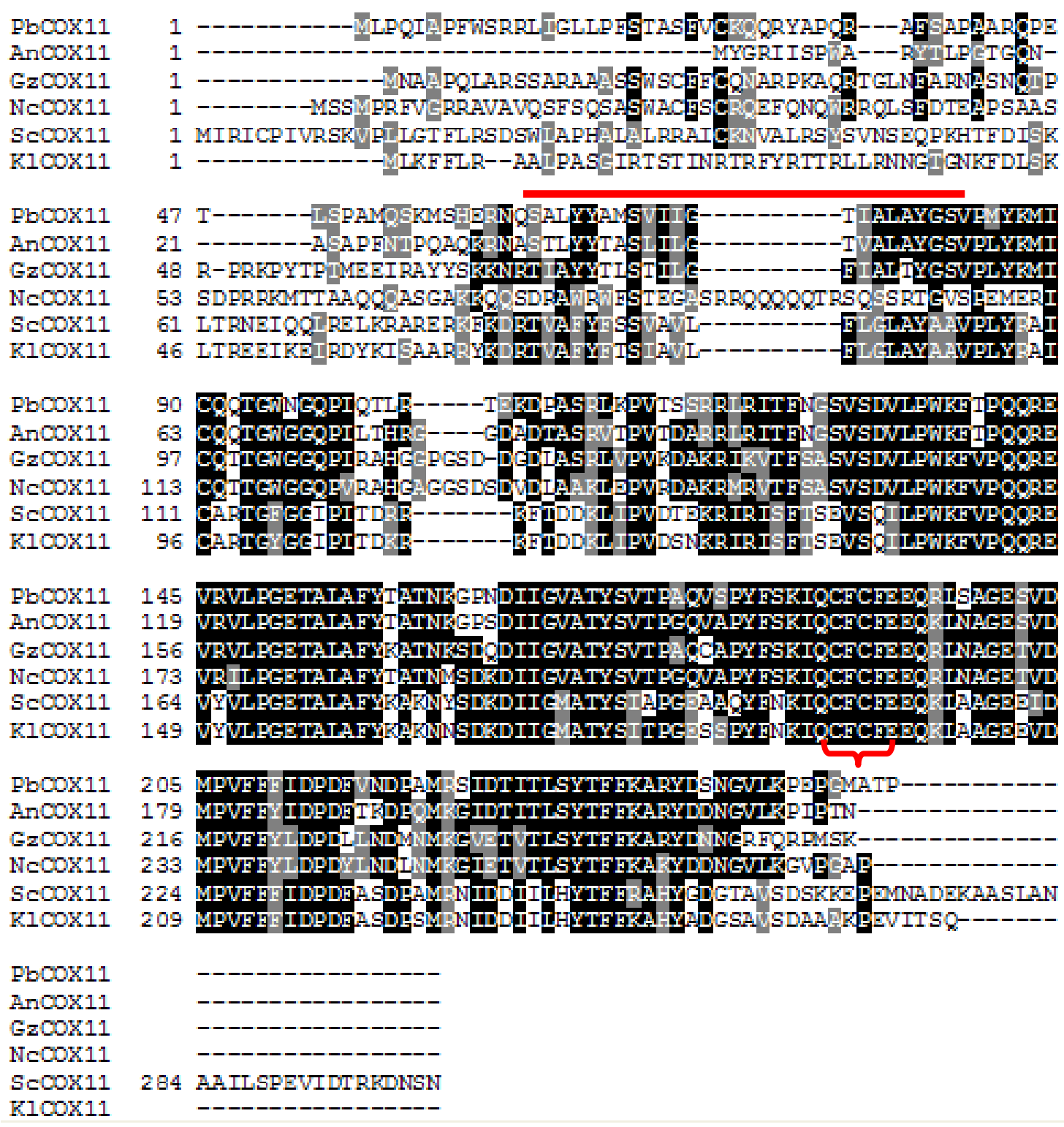

FIGURA 12: Alinhamento da PbCox11p de $P$. brasiliensis (Pb) com as proteínas homólogas Aspergillus nidulans (An), Gibberella zeae (Gz), Neurospora crassa (Nc), Saccharomyces cerevisiae (Sc) e Kluyveromyces lactis (Kl). Resíduos de aminoácidos idênticos são pintados em preto e resíduos com características semelhantes estão em cinza. A barra vermelha indica a região de hélice transmembrana (abaixo) e a chave indica o domínio ligante de cobre (acima).

\subsubsection{PbCOX13}

Para o estudo deste gene selecionamos a EST-CN243928-1 (Felipe et al., 2003). A seqüencia completa do inserto deste clone indicou a presença de uma ORF com 142 resíduos de aminoácidos (DQ003716) apresentando 32\% de identidade à proteína ScCox6a de S. cerevisiae. A ORF da PbCox13p foi extraída do vetor de clonagem pBluescript a partir de 
digestão enzimática com SacI e XhoI. Estes sítios fazem parte da região de clonagem do vetor. O fragmento contendo o gene $\mathrm{PbCOX13}$ foi clonado em vetor de expressão em S. cerevisiae, porem o teste de complementação funcional heteróloga no mutante se $S$. cerevisiae não foi realizado. Análise de comparação da seqüência da proteína PbCox13 com os polipeptídeos de outros organismos indica boa conservação de seqüência (Fig. 13).

$\operatorname{cox} 13$

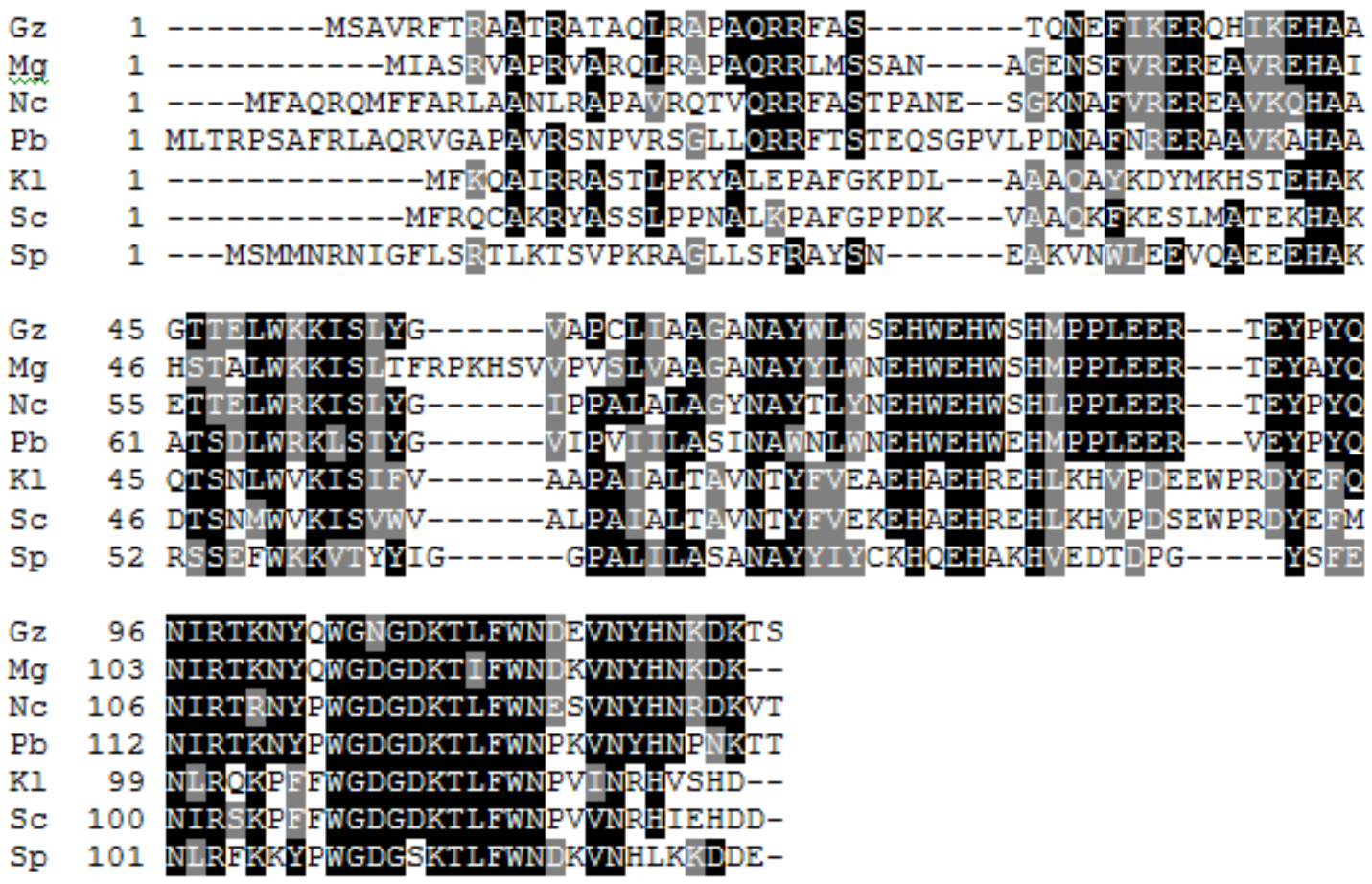

FIGURA 13: Alinhamento da PbCox13p de $P$. brasiliensis $(\mathrm{Pb})$ com as proteínas homólogas Gibberella zeae (Gz), Neurospora crassa (Nc), Saccharomyces cerevisiae (Sc) e Kluyveromyces lactis (Kl), Magnaporthe grisea (Mg) e Schizosaccharomyces pombe (Sp). Resíduos de aminoácidos idênticos são pintados em preto e resíduos com características semelhantes estão em cinza. 
Análise quanto à presença de resíduos característicos de hélice transmembrana revela alguns resíduos típicos de regiões transmembrana entretanto nenhuma estrutura de hélice é predita (Fig. 14A). Já a proteína ScCoxVIa de S. cerevisiae, através da mesma análise, apresenta uma região bem definida de hélice transmembrana (Fig. 14B). Esta observação pode ser um indicativo da não complementação funcional, a exemplo do que também pode estar ocorrendo com a proteína PbCox5A.

A
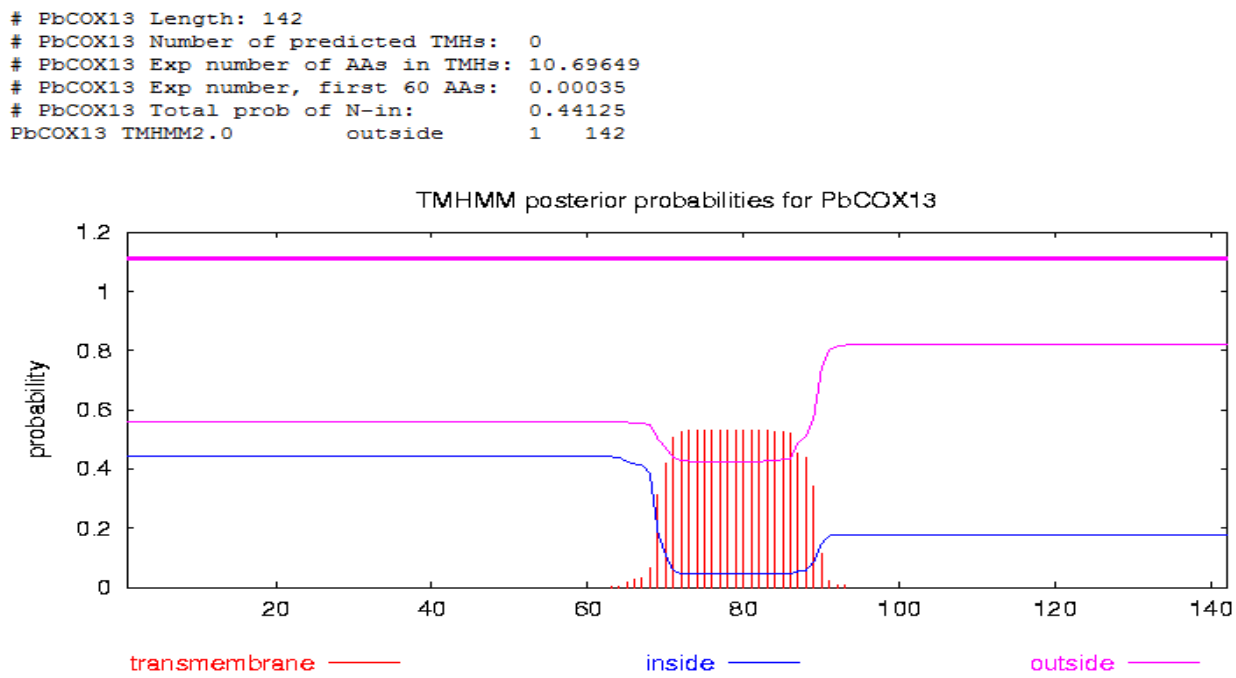

B

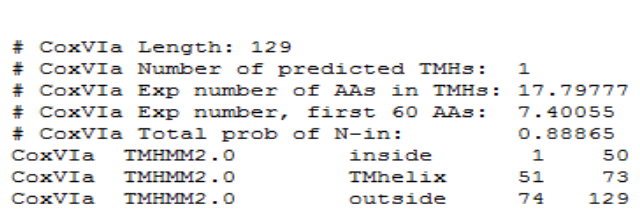

COXVIA TMHMM2.0

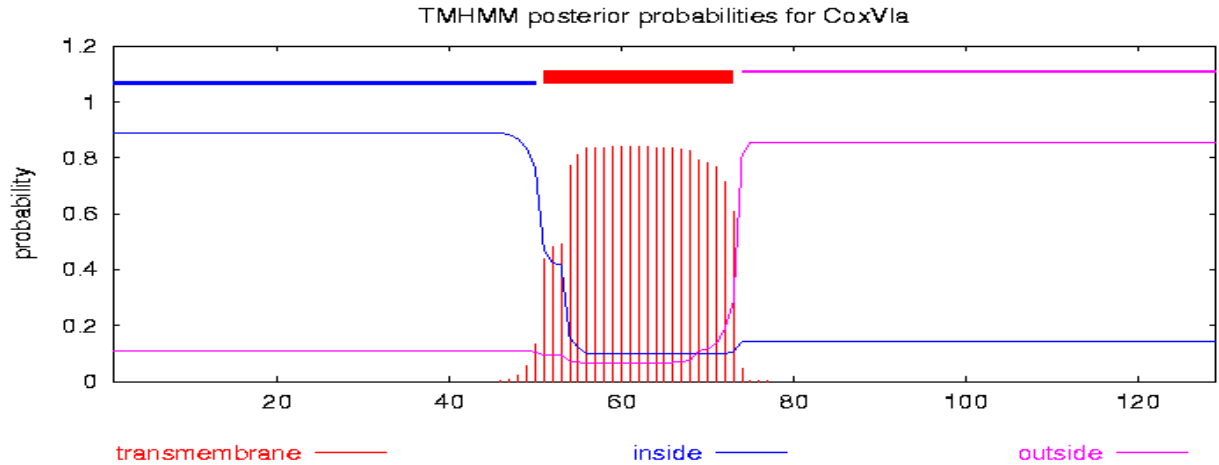

FIGURA 14A: Análise de resíduos característicos de hélices de transmembrana na PbCox13p.

obtida a partir da ferramenta TMHMM Server v. 2.0 disponível na página http://www.cbs.dtu.dk/services/TMHMM/. 14B: Análise semelhante com a proteína ScCoxVIa de $S$. cerevisiae. 
Em Saccharomyces cerevisiae, o gene nuclear COX13 codifica para o subunidade VIa do complexo da COX. Este é um gene de cópia unica por genoma haplóide (Taanman e Capaldi, 1993). Esta proteína é sintetizada como uma precursora compreendida de uma sequencia lider de nove (09) resíduos e um polipeptídeo maduro de 120 resíduos do aminoácido. Mutantes nulos de COX13 apresentam uma taxa de crescimento ligeiramente reduzida em fontes de carbono não fermentáveis entretanto o complexo da COX está integralmente montado nestas linhagens mutantes além deste complexo ser mais ativo em meios com baixa concentração iônica. Foram também observados efeitos distintos de ATP na atividade da COX entre a linhagem mutante cox13 e a selvagem (COX13), sugerindo que o ATP interage especificamente com esta subunidade, através da qual, modula a atividade da citocromo c oxidase mitocondrial (Taanman e Capaldi, 1993).

\subsubsection{PbCOX15}

Através da análise de comparação (tBLASTn) da seqüência protéica da Cox15p de $S$. cerevisiae contra o banco de dados de seqüências de ESTs e RSTs de P. brasiliensis, identificamos duas ESTs (EST006267 e EST007018) originarias da biblioteca do consórcio da região central do Brasil (Felipe et al., 2003), apresentando alto nível de similaridade, observado pelo valor de E-value (4e-27 e 6e-08) respectivamente.

O clone referente á EST006267 foi selecionado o para o estudo de caracterização do gene $\mathrm{PbCOX15}$ de $P$. brasiliensis. O inserto de cDNA foi completamente seqüenciado através da técnica de inserção de transposons (descrita em Material e Métodos) e verificou-se que ele é constituído de aproximadamente 2030 bp. Através da ferramenta ORFfinder do NCBI identificamos um fase aberta de leitura (ORF) correspondendo à proteína $P b \operatorname{Cox} 15 p$ que é constituída por 491 resíduos de aminoácidos. A seqüência completa do cDNA e a seqüência peptídica da PbCox15p foram depositadas no GenBank/NCBI sob o número de acesso DQ003717. A proteína deduzida a partir da ORF identificada compartilha 43\% de similaridade com a Cox15p de S. cerevisiae (Tabela 4) e tem uma predição de peso molecular de 55KDa.

A partir da análise física de restrição da seqüência do cDNA (utilizando a ferramenta NEBcutter www.neb.com) podemos nos certificar de que a ORF ( $P b C o x 15 p$ ) poderia ser excisada direcionalmente para a clonagem em vetor de expressão em $S$. cerevisiae utilizando as enzimas SacI e KpnI, que cortam nas extremidades 5' e 3’ respectivamente do plasmídeo, adjacentes ao inserto de cDNA. A digestão enzimática seguiu as instruções do fabricante 
(New England Biolabs). O fragmento de tamanho esperado foi separado em gel preparativo 1\% agarose eletroeluído e purificado por extração com fenol e éter seguido de precipitação com etanol.

Utilizando o kit de ligação (Fast Link ${ }^{\mathrm{TM}}$ DNA Ligation Kit -EPICENTRE TECHNOLOGIES), o fragmento SacI/PbCOX15/KpnI, purificado, foi ligado no vetor pMGL4 previamente linearizado com as mesmas enzimas e tendo as extremidades 5' defosforiladas com a enzima CIP - Calf Intestine Phosphatase. A mistura de ligação foi inserida em E. coli DH10B por transformação pelo método de $\mathrm{CaCl} 2$ e 10 transformantes foram coletados aleatoriamente. Os pDNAs dos transformantes coletados foram extraídos e a seleção do plasmídeo recombinante $p M G L 4 / P b C O X 15$ foi realizada através de sequenciamento utilizando o oligonucleotídeo (386 - 5’-CAATATTTCAAGCTATAC-3’) especifico para este plasmídeo. O recombinante selecionado foi então inserido por transformação pelo método de LiOAc no mutante nulo aW3034cox $15:$ HIS de S. cerevisiae. Os transformantes foram selecionados em meio mínimo (WO descrito em Material de Métodos) devidamente suplementado e a capacidade da proteína PbCox15p de restaurar a deficiência respiratória dos mutantes de $S$. cerevisiae foi analisada quanto à capacidade de crescimento em meio com fontes de carbono não fermentáveis (etanol e glicerol).

$\mathrm{O}$ crescimento dos transformantes incubados em estufa a $30^{\circ} \mathrm{C}$ foi observado durante o período suficiente e nenhum crescimento foi detectado em meio contendo etanol e glicerol como fonte de carbono, indicando que embora esta proteína PbCox15p de P. brasiliensis compartilhe $43 \%$ de similaridade com a proteína Cox15p de S. cerevisiae esta não é capaz de restaurar a deficiência respiratória do mutante aW303Acox15::HIS de levedura S. cerevisiae.

Em S. cerevisiae a proteína Cox15p foi inicialmente identificada por complementação de mutantes do grupo de complementação G4 (Tzagoloff et al., 1975) através de transformação de mutantes deste grupo com uma biblioteca genômica de levedura. Os mutantes deste grupo são deficientes respiratórios devido à incapacidade de síntese da citocromo c oxidase funcional, portanto, a proteína Cox15p é essencial para a montagem do complexo da citocromo c oxidase em S. cerevisiae (Glerum et al., 1997). Homólogos desta proteína foram identificados em Schizosaccharomyces pombe e Caenorhabditis elegans sugerindo que ela possa ser amplamente distribuída entre eucariotos (Glerum et al., 1997), inclusive nos humanos. A identificação e caracterização da $h$ Cox15p humana (Petruzzela et al., 1998) indica uma proteína (AF026850) de 255 resíduos apresentando cerca de 42\% de identidade com a Cox15p de $S$. cerevisiae e mutações neste gene humano h-COX15 já foi descrita como responsável pela desordem “Leigh syndrome” (Oquendo et al., 2004) e 
Antonicka et al., 2003, já havia descrito que a super expressão de hCOX15 pode complementar funcionalmente a deficiência isolada de citocromo c oxidase em fibroblastos de pacientes com cardiomiopatia hipertrófica infantil fatal, o que corrobora para importância de identificação de caracterização de genes associados a biosíntese deste complexo (COX).

Embora Glerum et al., 1997, sugira que a Cox15p não esteja relacionada ao metabolismo de cobre ou a biosíntese de heme A, Barros et al., 2001 descreve que mutações neste gene (COX15) levam a perda de absorção visível das bandas de citocromos a e a3 e promove aumento da freqüência de renovação traducional das subunidades da citocromo c oxidase. Diferentemente dos outros mutantes com perda de heme A, mutações no gene COX15 bloqueia a síntese do grupo prostético (heme A) e não bloqueia a síntese de heme $\mathrm{O}$, sugerindo um fenótipo consistente com uma mutação que possa bloquear o último estágio da biosíntese de heme A, na qual ocorre a substituição do grupo metil do carbono oito do anel da porfirina por um grupo formil (Barros et al., 2001). Em S. pombe, COX15 está fusionado à YAH1, que codifica uma ferredoxina mitocondrial e a fusão destes dois genes em S. cerevisiae recupera a deficiência de ambos os mutantes sugerindo que a Yah1p atuam em conjunto com a Cox15p e baseado nestes resultados Barros et al., 2001 sugere que a proteína Cox15p seja uma monooxigenase, que em conjunto com a ferredoxina mitocondrial YahI e a ferredoxina redutase Arh1 catalisem a hidroxilação do heme O.

A PbCox15p de Paracoccidioides brasiliensis quando comparada com homólogas de outros fungos apresenta-se muito bem conservada ao longo de quase toda a sua extensão (Fig. 15) deferindo apenas na região que compreende os primeiros noventa resíduos da região Nterminal e 10 a 12 resíduos na porção C-terminal. Esta diferença pode ser uma indicativa para explicar a não complementação funcional desta proteína $P b \operatorname{Cox} 15 p$ de $P$. brasiliensis no mutante de $S$. cerevisiae, sugerindo uma incompatibilidade de endereçamento para a mitocôndria, desde que normalmente a seqüência de endereçamento mitocondrial encontra-se na porção inicial das proteínas exatamente onde a $P b C o x 15 p$ não apresenta uma boa similaridade com a sua homóloga de $S$. cerevisiae.

Entretanto, pela análise quanto à presença de hélices transmembrana, pode-se observar uma total conservação dos domínios transmembrana entre as proteínas de $P$. brasiliensis e $S$. cerevisiae (Fig. 16A e 16B), tornando o resultado de incompatibilidade funcional um tanto curioso. 
COX15

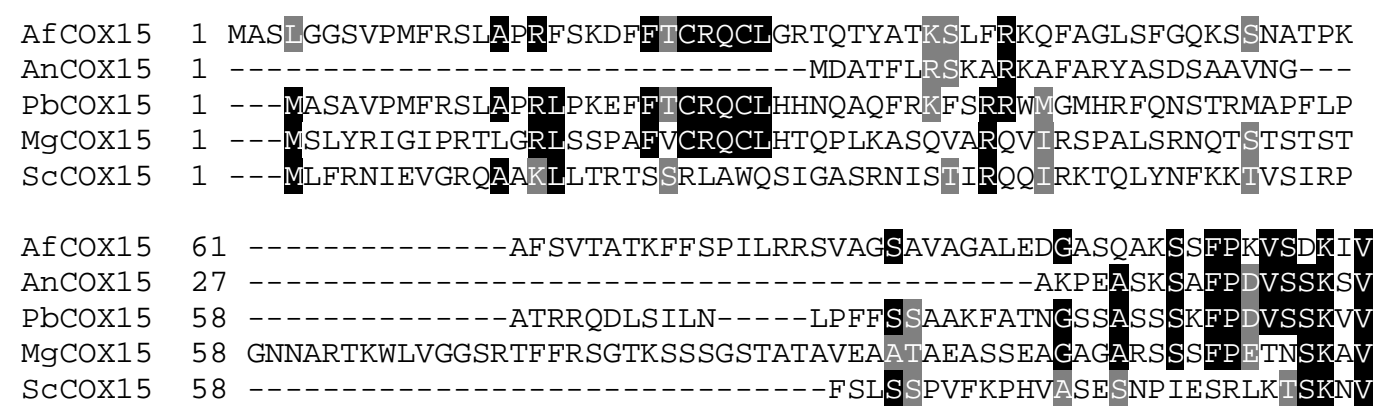

AfC0X15 107 AYWLLGSAASVFGIVVFGGLTRLTESGLSITEWRPVTGSLPPMNAEDWESEFAKYRASPE AnC0X15 45 AYWLLASAASVFGIVWFGGLTRLTESGLSITEWRPVTGSLPPMNAEDWESEFSKYRASPE PbC0X15 99 AYWLLGSAASVFGIVVFGGLTRLTESGLSITEWRPVTGSLPPFNTADWESEFEKYRSFPE MgC0X15 118 GYWLIGSAVSVFGIVIFGGLTRLTESGLSITEWRPVTGSLPPRNAEDWESEFSKYRASPE ScC0X15 87 AYWLIGTSGLVFGIVWLGGLTRLTESGLSITEWKPVTGTLPPMNQKEWEEEFIKYKESPE

$\begin{array}{llll}\text { AfcoX15 } & 167 & \text { YQQLNPNMNLSEFKSIYYMEWIHRLWGRFVGLSFVLPAIYFVAKKKVSKPMSLRLAGIAG } \\ \text { AncoX15 } & 105 & \text { FQLLNPTMTLSEFKSIYYMEWIHRLWGRFVGLSFVLPAVYFVARKKVSKPMVLRLGGIAG } \\ \text { PbCoX15 } & 159 & \text { YQVLRPNMTLSEFKFIYYMEWIHRQWGRFVGLSFVLPAAYFVATKRVSKPMSFRLLGISG } \\ \text { MgCoX15 } & 178 & \text { FALLNPHMTLDEFKKIYYMEWTHRLWGRFIGLTFVLPTVYFIARKQVTRKMAFLVGISA } \\ \text { ScC0X15 } & 147 & \text { FKLLNSHIDLDEFKFIFFMEWIHRLWGRAIGAVFILPAVYFAVSKKTSGHVNKRLFGLAG }\end{array}$

AfC0X15 227 LIGFQGFIGWWMVKSGLKEDLFAQG-SHPRVSQYRLTAHLGAAFICYTAMLWNGLAILRS AnC0X15 165 LIGFQGFIGWWMVKSGLKDDLFAPG-SHPRVSQYRLTAHLGAAFVCYTAMLWNGLAILRS PbC0X15 219 LIGFQGIIGWWMVKSGLKDDLFTPG-SHPRVSQYRLTAHLGSAFLCYTAMLWNGLAILRS MgC0X15 238 LIGFQGFIGWWMVKSGLKDDLFAPG-SHPRVSQYRLTTHLGTAFLCYSAMLLSGLSVLRT ScC0X15 207 LLGLQGFVGWWMVKSGLDQEQLDARKSKPTVSQYRLTTHLGTAFFLYMGMLWTGLEILRE

AfC0X15 286 HRLLADPEAGIKLLDSLRDPKLKIFRRSVAGLALLVFATAMSGALVAGLDAGLIYNEFPL AnC0X15 224 HRLLSDPEAGLKLLDSLKDPKLKLFRRSVAGLALLVFVTAMSGALVAGLDAGLIYNEFPW PbC0X15 278 NRLIADPSKGIEILNALRHPKLSIFRKSVAGLTLLVFATAMSGGLVAGLDAGLIYNEFPY MgC0X15 297 RRLVADPTAATKLFSQLKNAAITPFRRYVLAMTALVFTTAMSGALVAGLDAGLIYNEFPK ScC0X15 267 CKWIKNPVQAISLFKKLDNPAIGPMRKISLALLAVSFLTAMSGGMVAGLDAGWVYNTWPK

AfCOX15 346 MGNGLAPPKSELLDERYSRHEDRSDLWWRNMLENPSLVQLDHRTMAMTTFTSTMALWAYS AnC0X15 284 MGNGLAPPMSELFDDRYSRHEDRSDRWWRNMLENPSLVQLDHRILAMTTFTSIMALWAY PbC0X15 338 MGERFVPPTSELFSSHYSRLADKSDLWWRNMLENPSLVQLNHRILAMTTFSSVMGLWAYT MgC0X15 357 MGVGLTPPMTELFDKFYSRKEDGSDLWWRNMLENPSLVQLDHRALAMTTFCAVVAMFVWS SCCOX15 327 MGERWFPSSRELMDENFCRREDKKDLWWRNLLENPVTVQLVHRTCAYVAFTSVLAAHMA
Afcox15 406 AncoX15 344 PbC0X15 398 $\operatorname{MgC0X15} 417$ $\operatorname{ScC0X15} 387$

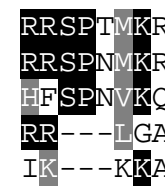
AfCoX15 466 AncoX15 404 Pbc0X15 458 $\operatorname{MgC0X15} 474$ VLSHVSKSTVSLIQRQLLKSAGSGGAARLPTKRI - . - . - SCCOX15 444 VFASQLRKPRAPMRNVIITLPHSSKVTSGKILSEASKLASKPL

FIGURA 15: Alinhamento da PbCox15p de $P$. brasiliensis $(\mathrm{Pb})$ com as proteínas homólogas. Aspergillus nidulans (An), Aspergillus fumigatus (Af), Magnaporthe grisea (Mg) e Saccharomyces cerevisiae (Sc). Resíduos de aminoácidos idênticos são pintados em preto e resíduos com características semelhantes estão em cinza. 
A

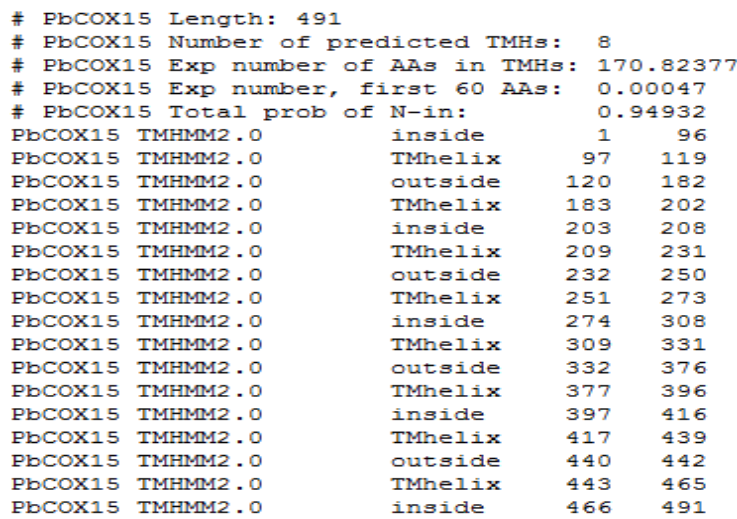

TMHMM posterior probabilities for $\mathrm{PbCOX15}$

B

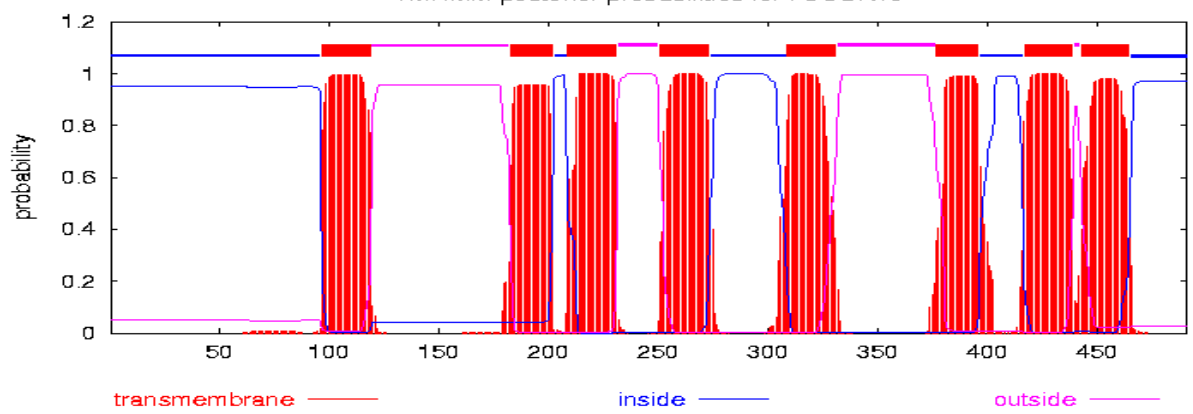

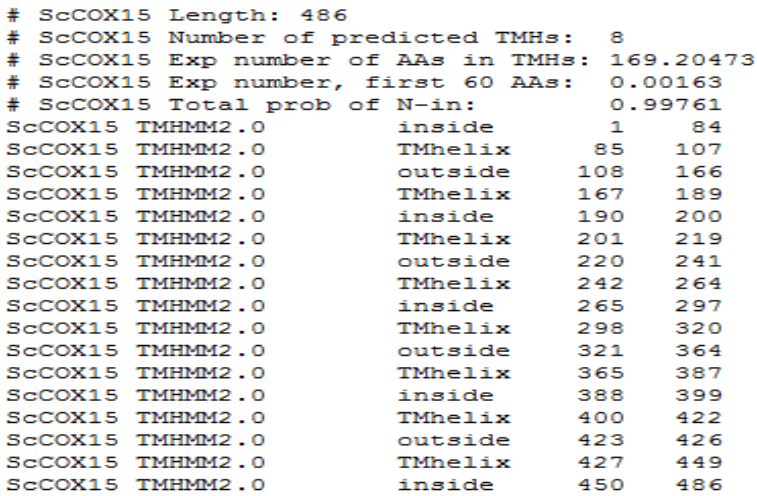

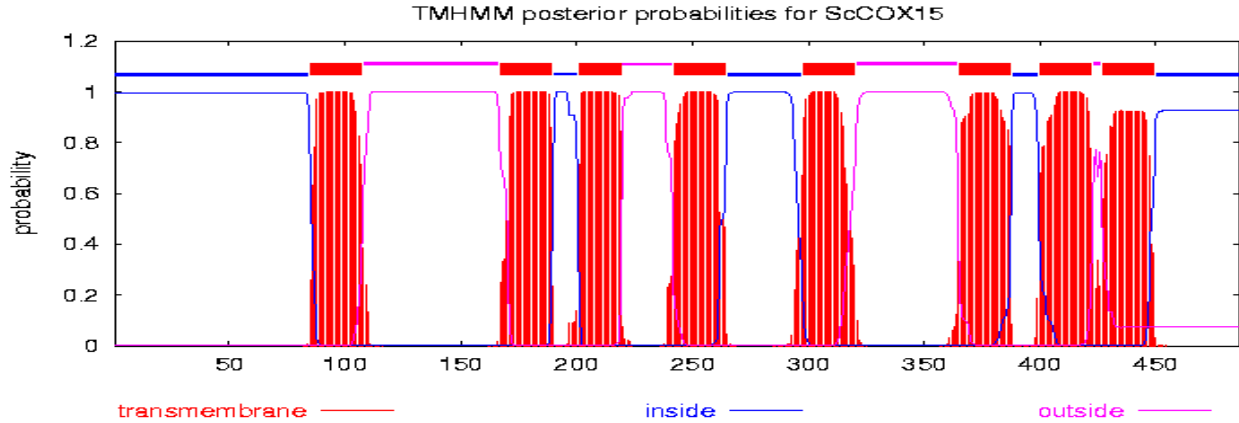

FIGURA 16A: Análise de resíduos característicos de hélices transmembrana na $P b C o x 15 p$.

obtida a partir da ferramenta TMHMM Server v. 2.0 disponível na página http://www.cbs.dtu.dk/services/TMHMM/. 16B: Análise semelhante com a proteína ScCox15p de $S$. cerevisiae. 


\subsubsection{PbCOX17}

Identificamos pelos menos seis ESTs nos bancos de dados do P. brasiliensis apresentando excelente valor de E-value. Todas elas são do consórcio da região central do Brasil (Felipe et al., 2003). Para o estudo deste gene de $P$. brasiliensis selecionamos a EST (EST006191). O inserto de cDNA originalmente clonado no pBluescript (Stratagene) foi completamente seqüenciado e contem aproximadamente 700bp. Análise da seqüência pela ferramenta ORFfinder do NCBI revelou a presença de uma ORF de 78 resíduos de aminoácidos (predição de 8,3KDa) apresentando 47\% de identidade com a proteína $S c C o x 17 p$ de S. cerevisiae.

A seqüência completa do cDNA do PbCOX17 foi submetida à analisada física de restrição utilizando a ferramenta nebcutter disponível no página da New England Biolabs. Embora na região do cDNA não existisse sítios apropriados, foi possível excisar a ORF, direcionada para clonagem em vetor de expressão, utilizando os sítios SacI e XhoI presentes na seqüências adjacentes, que compreende as extremidades da inserção do plasmídeo. O fragmento SacI/PbCOX17/XhoI, purificado, foi ligado no vetor pMGL4 previamente linearizado com as enzimas SacI e SalI e tendo as extremidades 5' desfosforiladas. A mistura de ligação foi inserida por transformação em E. coli DH10B competente. Coletamos 10 clones aleatoriamente para extração do pDNA e a seleção do recombinante $p M G L 4 / P b C O X 17$ foi realizada por seqüenciamento. O recombinante $p M G L 4 / P b C O X 17$ foi então inserido por transformação no mutante nulo de $S$. cerevisiae aW3034cox17/TRIP pelo método de LiOAc. Os transformantes foram selecionados em meio mínimo WO devidamente suplementado e a capacidade de complementação funcional da deficiência respiratória do mutante de levedura pelo gene COX17 de $P$. brasiliensis foi observada pelo crescimento do mutante em etanol e glicerol (EG). Todos os recombinantes aW3034cox17/TRIP/pMGL4/PbCOX17 apresentaram crescimento comparável ao selvagem (Fig. 17) após o período de 48 horas de incubação a 30 ${ }^{\circ} \mathrm{C}$.

Os resultados do ensaio de complementação funcional da proteína $P b C o x 17 p$ em mutantes de $S$. cerevisiae indica que esta proteína é homóloga à proteína $S c C o x 17 p$.

O alinhamento da proteína $P b \operatorname{Cox} 17 p$ de $P$. brasiliensis com as proteínas homólogas de outros fungos (Fig. 18) indica que não existe boa similaridade na seqüência de endereçamento mitocondrial entre as proteínas comparadas. Entretanto, o restante da seqüência protéica apresenta-se com similaridade bem homogênea o que provavelmente 
contribua para a preservação da função em ambos os fungos ( $P$. brasiliensis e $S$. cerevisiae), observado no sucesso da complementação funcional.

ScCox17p foi originalmente caracterizado em S. cerevisiae (Glerum et al., 1996a) através de rastreamento genético por complementação funcional de mutantes com deficiência respiratória devido a inatividade do complexo da citocromo c oxidase. A deficiência respiratória dos mutantes de cox17 é restaurada pela adição de sais de cobre ao meio de cultura sugerindo que a $S c \operatorname{Cox} 17 p$ esteja envolvida no transporte desses íons para a mitocôndria (Glerum et al., 1996a). A proteína ScCox17p é uma metalochaperona encontrada tanto no citoplasma quanto no espaço intermembrana mitocondrial (Beers et al., 1997) envolvida no transporte de íons cobre tanto para Sco1p quanto para Cox11p na formação do centros CuA e CuB, respectivamente, no complexo da COX (Horng et al., 2004).

Nenhum domínio de hélice transmembrana é identificado nesta proteína em qualquer organismo. A resolução por resonância magnetica nuclear (NMR) da estrutura desta proteina em estado oxidado mostrou que a Cox17p é encontrada em conformação “coiled-coil” estabilizada por duas pontes disulfeto envolvendo as cisteínas Cys(26)/Cys(57) e Cys(36)/Cys(47). Esta forma terciária tem sido observada entre as proteínas que fazem parte de uma classe de proteínas localizada no espaço intermembranar que contém o motivo Cysx(9)-Cys, com duas cisteínas sempre espaçadas por nove resíduos de aminoácidos (Arnesano et al., 2005). 

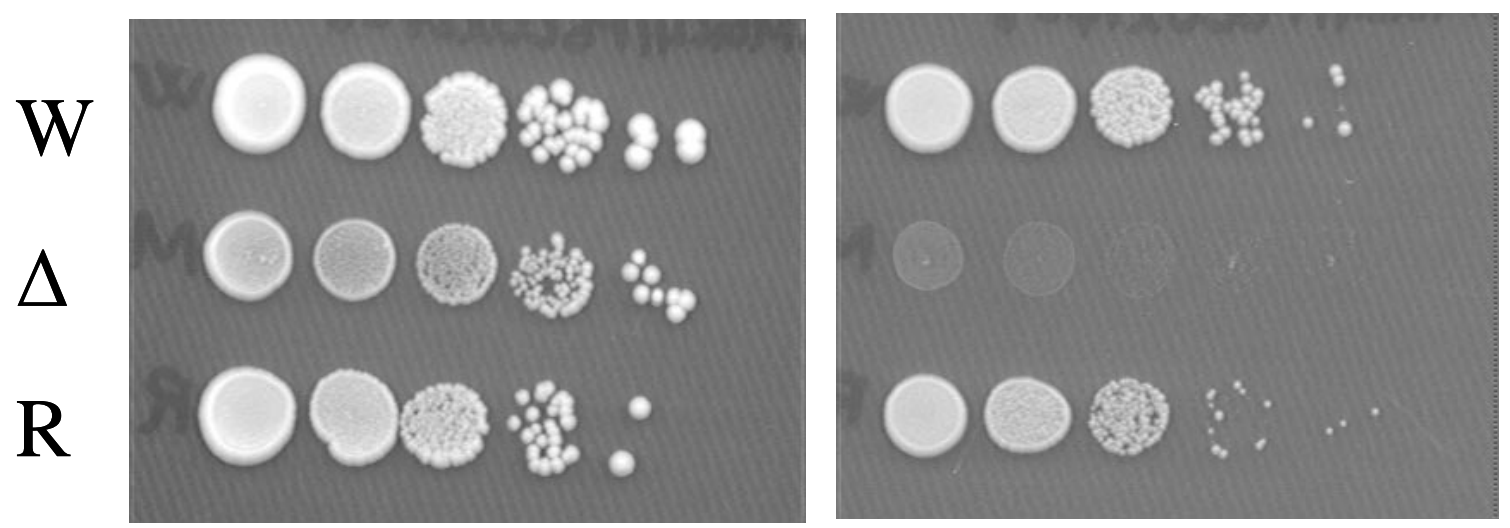

FIGURA 17- Complementação Funcional da PbCox17p.

Crescimento das linhagens selvagem (W), mutante deficiente respiratória de $S$. cerevisiae $a W 3 O 3 \Delta \operatorname{cox} 17:: T R I P(\Delta)$ e do recombinante $a W 3 O 3 \Delta \operatorname{cox} 17:: T R I P / p M G L 4 / P b C O X 17$ (R) em meio rico YPD e em meio contendo etanol/glicerol como fonte de carbono (EG) após 48 horas de incubação a $30^{\circ} \mathrm{C}$.

\section{$\operatorname{cox} 17$}

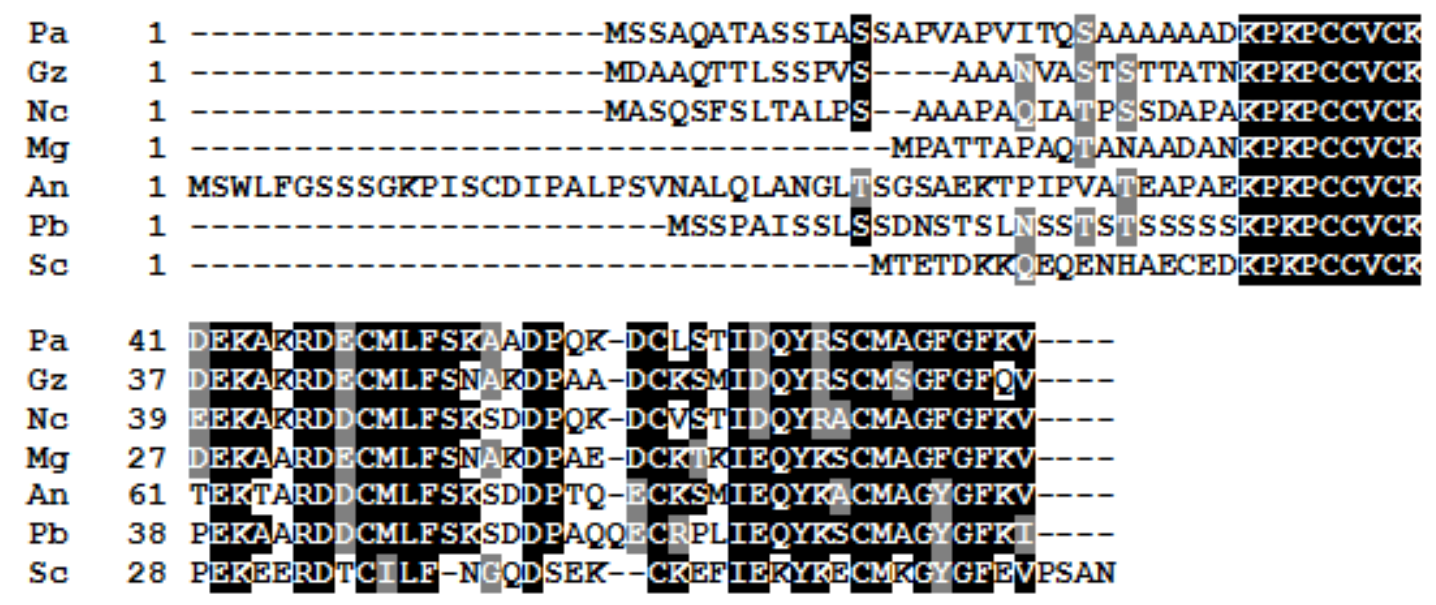

FIGURA 18: Alinhamento da $P b C o x 17 p$ de $P$. brasiliensis $(\mathrm{Pb})$ com as proteínas homólogas. Aspergillus nidulans (An), Magnaporthe Grisea (Mg), Neurospora crassa (Nc), Gibberella zeae (Gz), Podospora anserina (Pa) e Saccharomyces cerevisiae (Sc). 


\subsubsection{PbCOX19}

Somente uma seqüência de EST foi identificada no bancos de dados de seqüência de P. brasiliensis, apresentado boa similaridade à proteína ScCox19p de S. cerevisiae. O clone correspondente a EST014900 pertence à biblioteca do consórcio da região central do Brasil (Felipe et al., 2003).

O inserto de cDNA compreendendo cerca de $1 \mathrm{~kb}$ foi completamente seqüenciado. A análise da seqüência indicou a presença da ORF completa, correspondente à proteína PbCox19p, constituída por 107 resíduos de aminoácidos (predição de 11,3KDa) com 51\% de identidade à proteína Cox19 de S. cerevisiae.

Através da análise física de restrição da seqüência do cDNA verificou-se a possibilidade de excisão da ORF direcionada para clonagem em vetor de expressão utilizando as enzimas SacI e XhoI. Após a digestão enzimática, o fragmento SacI/PbCOX19/XhoI foi isolado em gel preparativo $1 \%$ agarose extraído por eletroeluição e purificado por precipitação com etanol. O fragmento purificado foi ligado no vetor pMGL4 previamente linearizado com as enzimas SacI e SalI e tendo as extremidades 5' desfosforiladas. A mistura de ligação foi inserida em E. coli $D H 10 B$ por transformação e dez (10) transformantes foram coletados aleatoriamente. Os pDNAs dos transformantes foram extraídos e a seleção do plasmídeo recombinante $p M G L 4 / P b C O X 19$ foi realizada através de seqüenciamento. $\mathrm{O}$ recombinante escolhido foi inserido por transformação pelo método de $\mathrm{LiOAc}$ em duas linhagens de mutantes nulos cox19 distintos de S. cerevisiae. A linhagem mutante com deleção parcial do gene COX19 ( $\alpha$ W3034cox19::LEU) e a linhagem mutante com deleção total do gene (aW3034cox19::HIS). Os transformantes foram selecionados em meio mínimo WO devidamente suplementado e a capacidade do gene PbCOX19 de restaurar a função respiratória deficiente desses mutantes foi analisada quanto ao crescimento em meio com fonte de carbono não fermentável (etanol e glicerol). Após 48 horas de incubação em estufa a $30{ }^{\circ} \mathrm{C}$ verificou-se o crescimento das linhagens recombinantes de $S$. cerevisiae com o gene PbCOX19 de $P$. brasiliensis em níveis comparáveis ao da linhagem selvagem (Fig. 19) indicando que este gene de P. brasiliensis é ortólogo ao gene ScCOX19 da levedura S. cerevisiae. Este resultado foi confirmada a partir de extração do pDNA de alguns transformantes e fazendo-se a transformação reversa nos mutantes de levedura.

Em S. cerevisiae a ScCox19p é uma proteína de aproximadamente 11-kDa necessária para a atividade da citocromo c oxidase (Nóbrega et al., 2002). Assim como ScCox17p, a proteína ScCox19 é uma proteína solúvel encontrada tanto no citoplasma como na 
mitocôndria e á essa semelhança soma-se a presença de quatro cisteínas conservadas na proteína $S c C o x 19$ em relação à $S c C o x 17$ sugerindo que, assim como $S c C o x 17 p$, a proteína ScCox19p também possa estar envolvida no transporte de cobre do citoplasma para a mitocôndria (Nóbrega et al., 2002). Podemos observar na (Fig. 20) que as cisteínas são conservadas em todos os organismos comparados corroborando para a importância desse aminoácido na função da mesma. Assim como a proteína Cox17p, nenhum domínio de hélice transmembrana foi identificado na proteína Cox19p.

Este não é o primeiro relato em que as proteínas Cox17 e Cox19 são submetidas em ensaios de complementação funcional heteróloga em mutantes de S. cerevisiae. Resultados similares também foram obtidos os genes COX17 e COX19 da planta A. thaliana (Balandin and Castresana, 2002; Attallah et al., 2007) e com o gene COX17 humano (Amaravadi et al., 1997). Estes resultados indicam que esta proteína é bem conservada entre as diferentes espécies de eucarioto. 


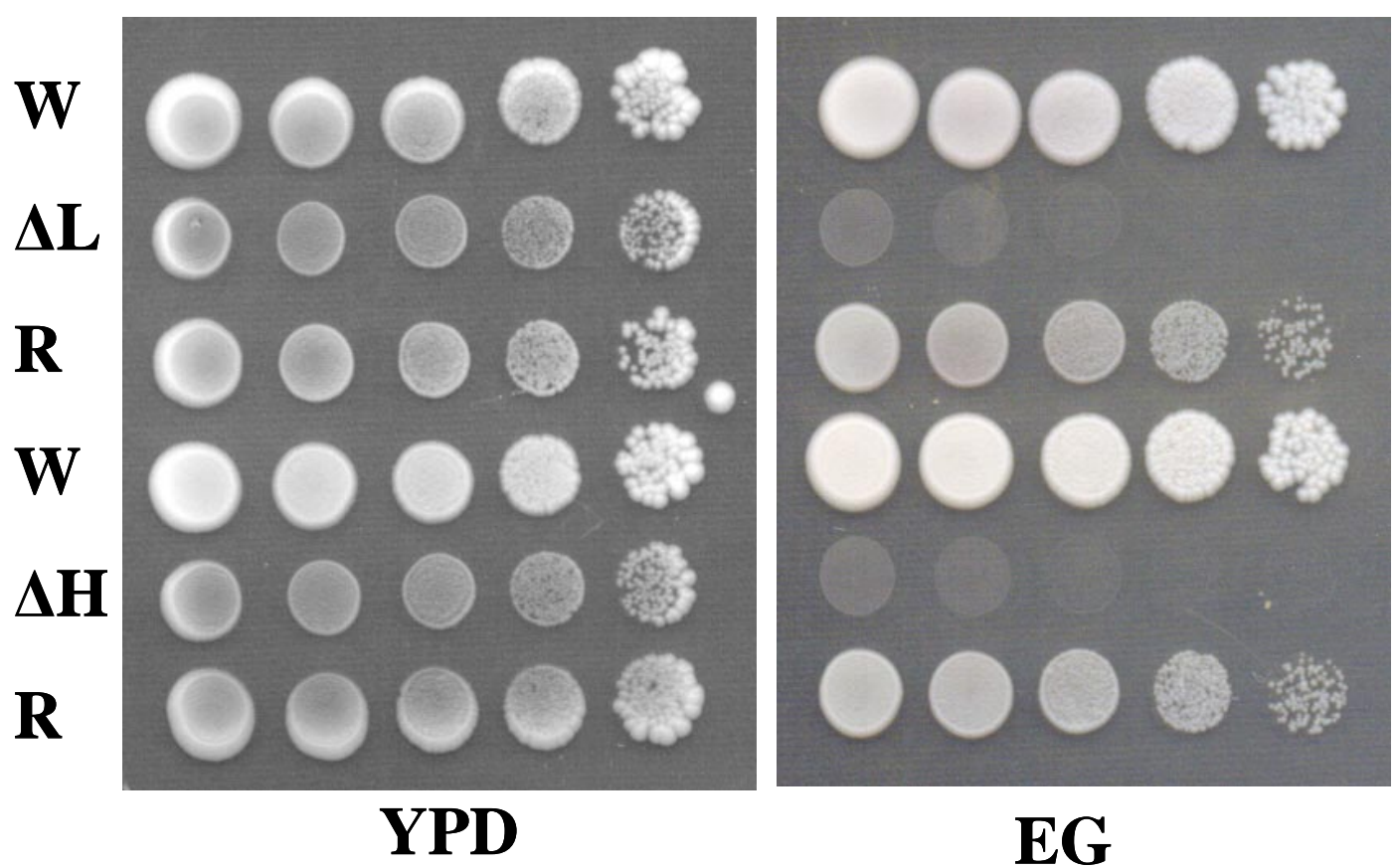

FIGURA 19: Complementação Funcional da PbCox19p. Crescimento das linhagens selvagem W303 (W), dos mutante deficientes respiratório de $S$. cerevisiae $\alpha W 3 O 3 \Delta \operatorname{cox} 19:: L E U(\Delta \mathbf{L})$ e

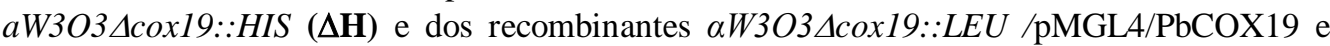
aW3O3Аcox19::HIS/pMGL4/PbCOX19 (R) em meio rico YPD e em meio contendo etanol/glicerol como fonte de carbono (EG) após 48 horas de incubação a $30^{\circ} \mathrm{C}$.

Cox19

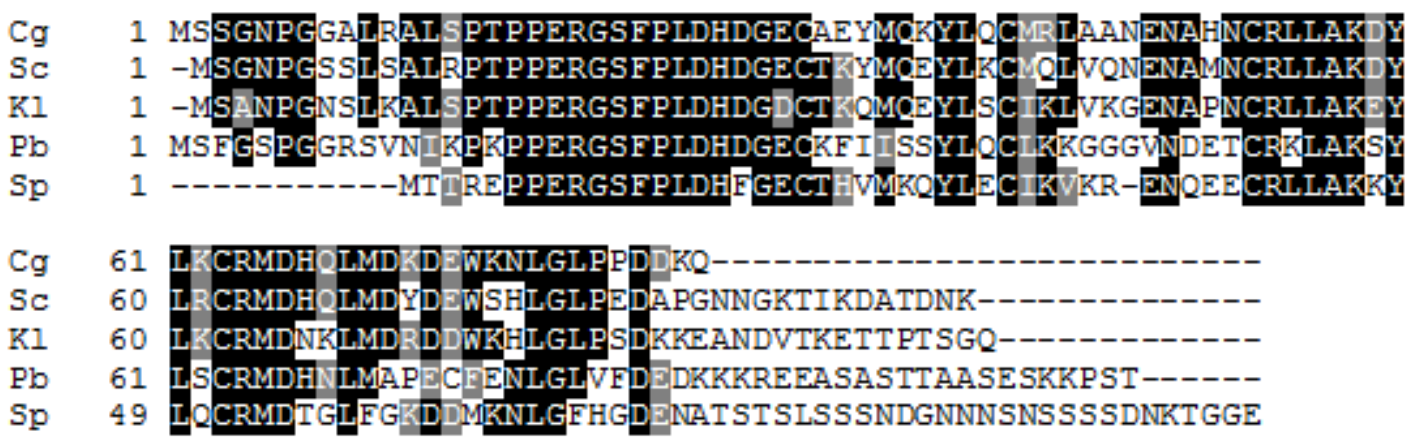

FIGURA 20: Alinhamento da PbCox19p de P. brasiliensis (Pb) com as proteínas homólogas. de Candida glabrata (Cg), Schizosaccharomyces pombe (Sp) Kluyveromyces lactis (Kl) e Saccharomyces cerevisiae (Sc). 


\subsubsection{PbCOX23}

A busca por ESTs de $P$. brasiliensis que apresentassem similaridade com a proteína Cox23p de S. cerevisiae retornou três clones distintos de ESTs (EST008699 eST001598 e EST019466), todos pertencentes ao consórcio da região central do Brasil (Felipe et al.,2003). Para o estudo deste gene de P. brasiliensis selecionamos o clone EST008699. O fragmento do inserto de cDNA foi inteiramente seqüenciado e é constituído de aproximadamente 800bp e a região codificadora da $P b C o x 23 p$ é constituída por 76 resíduos de aminoácidos que apresenta 43\% de similaridade à proteína homóloga de S. cerevisiae (Tabela 4). O alinhamento entre as regiões é significativo entre os resíduos 81 a 147 aa da ScCox23p que é constituída por 151 aa (Fig. 21). A ORF da proteína PbCox23p de $P$. brasiliensis está localizada bem no início da seqüência do cDNA da EST, que apresenta uma longa região 3'UTR (não traduzida). Outra ORF de 104 resíduos é observada em outra fase aberta de leitura deste mesmo cDNA, porém esta não apresenta similaridade com nenhuma outra proteína depositada nos bancos de dados do GenBank/NCBI. Esta observação poderia indicar que a ORF codificadora da proteína PbCox23 de $P$. brasiliensis não esteja completa no fragmento de cDNA entretanto, quando olhamos para o alinhamento com as homólogas de outros fungos (Fig. 22) podemos observar grande diversidade em ambas as extremidades da proteína. S. cerevisiae possui a maior região $\mathrm{N}$-terminal enquanto que em Aspergillus nidulans verifica-se a maior região C-terminal. A ORF referente à PbCox23p de Paracoccidioides brasiliensis apresenta maior similaridade com a proteína homóloga de Neurospora crassa (Fig. 22). Considerando que somente $S$. cerevisiae e Kluveromyces latis contem uma extensa região N-terminal e que a parte conservada da proteína Cox23 encontra-se na região central, é possível que a ORF de 76 resíduos encontrada na EST008699 de $P$. brasiliensis possa estar completa. As seqüências nucleotídica e peptídica da proteína $P b \operatorname{Cox} 23 p$ foram submetidas ao banco de dados do GenBank/NCBI e pode ser acessada através do numero de acesso DQ402182. 


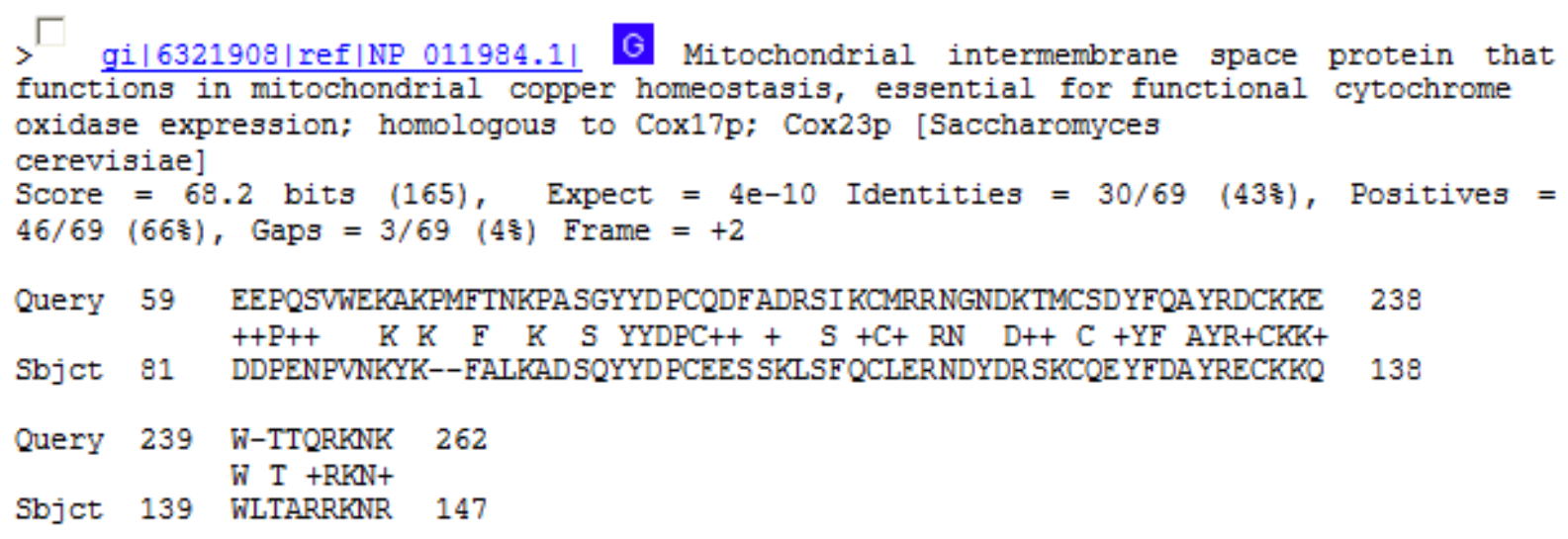

FIGURA 21:Comparação entre a PbCox23p e a seqüência da proteína ScCox23.

Alinhamento por BLASTx entre as seqüências completa do cDNA da EST008699 de P. brasiliensis correspondente à proteína $\mathrm{PbCox} 23$ e a seqüência da proteína $S c C o x 23$ de S. cerevisiae.

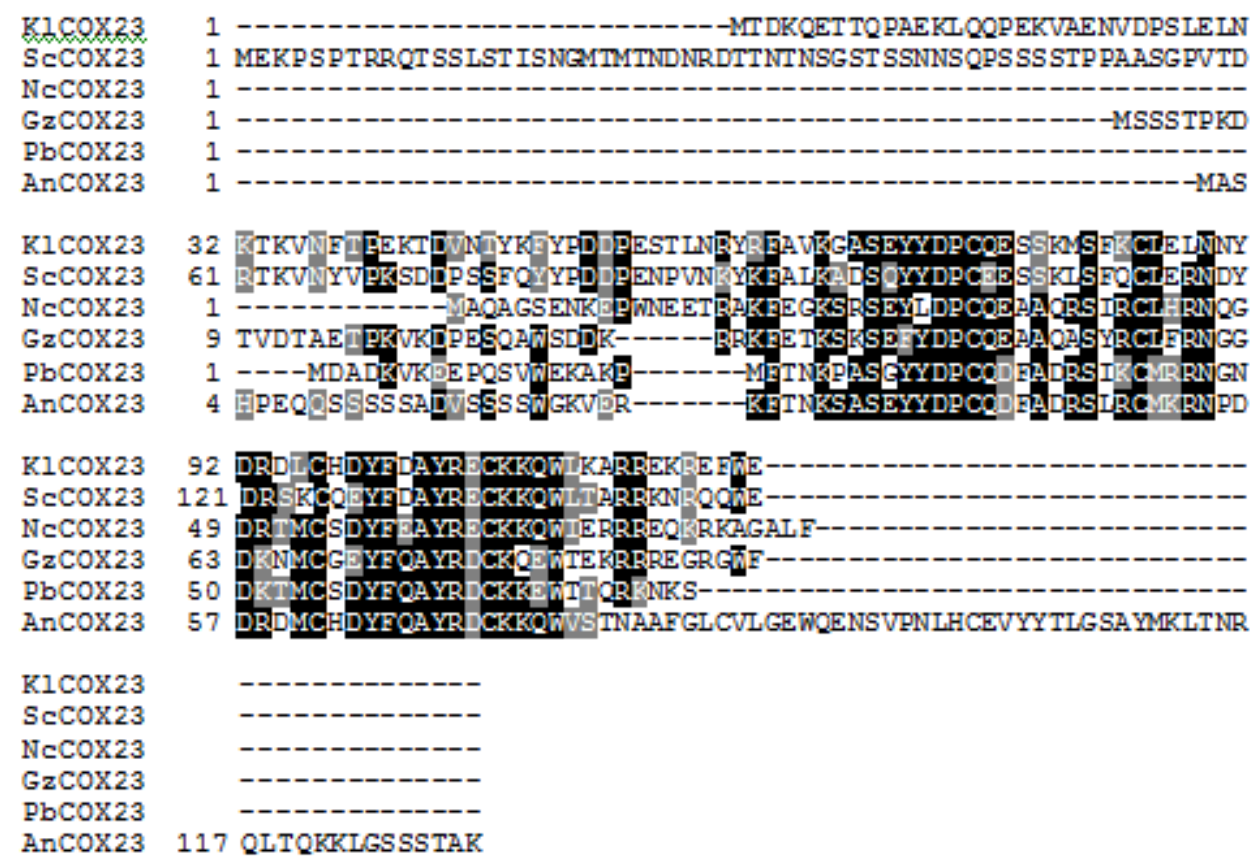

FIGURA 22: Alinhamento da Cox23p de $P$. brasiliensis $(\mathbf{P b})$ com as proteínas homólogas. de Aspergillus nidulans (An), Saccharomyces cerevisiae (Sc), Gibberella zeae (Gz), Neurospora crassa (Nc) e Kluveromyces lactis (Kl). Resíduos de aminoácidos idênticos são pintados em preto e resíduos com características semelhantes estão em cinza. 
A excisão a região codificadora da proteína $P b \operatorname{Cox} 23 p$ direcionada para clonagem no vetor de expressão em $S$. cerevisiae foi realizada através de dupla digestão com as enzimas SacI e KpnI.

A digestão enzimática seguiu as instruções do fabricante (New England Biolabs). O fragmento de tamanho esperado foi separado em gel preparativo 1\% agarose eletroeluído, purificado por extração com fenol e éter e precipitação com etanol. A ligação do fragmento SacI/PbCOX23/KpnI purificado no vetor pMGL4 foi realizada utilizando-se o kit de ligação (Fast Link ${ }^{\mathrm{TM}}$ DNA Ligation Kit -EPICENTRE TECHNOLOGIES). A mistura de ligação foi inserida em E. coli $\mathrm{DH} 10 \mathrm{~B}$ por transformação pelo método de $\mathrm{CaCl} 2$ e 10 transformantes foram coletados aleatoriamente. Os pDNAs dos transformantes coletados foram extraídos e a seleção do plasmídeo recombinante $p M G L 4 / P b C O X 23$ foi realizada através de seqüenciamento utilizando o oligonucleotídeo (386 - 5'-CAATATTTCAAGCTATAC-3'). O recombinante selecionado foi inserido por transformação, pelo método de LiOAc, no mutante nulo a4741 4 cox $23:: M H L U$ de $S$. cerevisiae. Os transformantes foram selecionados em meio mínimo WO devidamente suplementado e a capacidade de complementação funcional da proteína $P b C o x 23 p$ em restaurar a deficiência respiratória dos mutantes de $S$. cerevisiae foi analisada quanto à capacidade de crescimento em meio com fontes de carbono não fermentáveis (etanol e glicerol). O crescimento dos transformantes incubados em estufa a 30 ${ }^{\circ} \mathrm{C}$ foi observado durante o período necessário entretanto nenhum crescimento foi detectado nesta condição, indicando que esta proteína não é capaz de restaurar a deficiência respiratória do mutante de levedura $S$. cerevisiae.

A Cox23p de S. cerevisiae é uma proteína solúvel também presente no citoplasma e no espaço intermembranar mitocondrial. Sendo uma proteína solúvel também não apresenta domínios de hélice transmembrana. É requerida para a homeostase mitocondrial e mutação neste gene leva à deficiência respiratória devido à ausência da citocromo c oxidase funcional (Barros et al., 2004). A Cox23p é homologa da Cox17p (Barros et al., 2004), uma metalochaperona (Beers et al., 1997) envolvida no transporte de cobre para a mitocôndria (Glerum et al., 1996). Barros et al., 2004, também reporta que homologas desta proteína em alguns fungos e em humano também são desprovidas de região N-terminal longa existente na proteína Cox23p de S. cerevisiae e que a Cox23p de S. cerevisiae truncada nos primeiros 75 resíduos ainda retém a capacidade de complementação funcional do respectivo mutante. Este resultado favorece nossas expectativas de que a ORF de 76 resíduos, identificada no genoma de $P$. brasiliensis possa realmente estar completa e que a incapacidade de complementação 
funcional desta proteína PbCox23p no mutante a4741 4 cox $23: \because M H L U$ de $S$. cerevisiae não esteja relacionada à ausência da porção $\mathrm{N}$-terminal.

\subsubsection{PbPET100}

Na busca inicial por seqüências de ESTs de $P$. brasiliensis similares à proteína Pet100p de S. cerevisiae identificamos somente um clone de EST (EST002126) o qual pertence ao consórcio da região central do Brasil (Felipe et al., 2003). O inserto de cDNA deste clone foi completamente seqüenciado e análise com a ferramenta ORFFinder do NCBI identificou uma ORF com 72 resíduos de aminoácidos com 39\% de identidade à proteína ScPet100p de S.cerevisiae que é constituída por 111 resíduos. Esta ORF de 72 resíduos de $P$. brasiliensis não apresenta, portanto, a região N-terminal da proteína. Entretanto, na análise pela ferramenta BLASTX/NCBI da seqüência completa do inserto do cDNA indicou que a região N-terminal está presente, alinhando com similaridade razoável à região N-terminal da proteína ScPet100p.

Em uma nova busca, agora utilizando a seqüência do inserto de cDNA do clone da EST002126 como sonda, identificamos vários outros clones que apresentam similaridade com a proteína Pet100p e inclusive uma EST (RC2-Pb30001-125H07) representante do isolado Pb18, já que a EST002126 é originária do isolado Pb01. Portanto, além da possibilidade de identificarmos a fase de leitura completa referente à proteína PbPet100p, agora também teríamos a possibilidade de verificarmos se havia diferenças neste gene entre os dois isolados (Pb01 e Pb18) de Paracoccidioides brasiliensis.

O inserto do clone referente a EST-RC2-Pb30001-125H07 foi totalmente seqüenciado e a seqüência obtida foi submetida à análise através da ferramenta ORFfinder/NCBI. Neste clone identificamos uma ORF com 103 resíduos apresentando 42\% de identidade com a proteína Pet100p de S. cerevisiae. As seqüências nucleotídica e peptídica foram submetida ao GenBank/NCBI sob o número de acesso AY603796. A proteína PbPet100p predita, apresenta uma massa molecular estimada de 11,5 KDa. A análise através da ferramenta ORFfinder mostra a presença de uma microORF (34 resíduos de aminoácido) em fase de leitura com ORF de 103 resíduos referente a PbPet100p na região 5’UTR, indicando que este gene possa ser regulado pos-transcricionalmente, ou seja, durante a tradução.

Utilizando o par de iniciadores (senso- 5' AGAAAGAGCTCGAAAGAAA 3' e antisenso- 5' ACCGATCTGCAGTTAAAA 3') a região da ORF de 103 resíduos foi amplificada a partir do cDNA original e clonada no vetor de expressão pMGL3 de S. cerevisiae. Através 
dos iniciadores utilizados para amplificação da ORF, foi inserido os sítios de reconhecimento para as enzimas SacI e PstI, nas extremidades 5' e 3', respectivamente. O fragmento amplificado e purificado foi inserido por transformação em célula competente E.coli DH10B.

Após a transformação da mistura de ligação em E.coli DH10B os pDNAs dos transformantes foram extraídos e analisados por seqüenciamento. O recombinante pMGL3/PbPET100 selecionado foi utilizado no ensaio de complementação funcional do mutante nulo aW303 4 pet100/HIS de S. cerevisiae. Não obtivemos a complementação funcional da deficiência respiratória deste mutante de $S$. cerevisiae com o gene PbPET100, indicando que a PbPet100p não é capaz de substituir a função da ScPet100p.

Através de análise de comparação de seqüência das duas ESTs de P. brasiliensis referentes ao gene PbPET100, sendo a EST002126 do isolado Pb01 e a EST-RC2-Pb30001125H07 do isolado Pb18, verificou-se a existência de diferenças de seqüência entre os dois isolados. A análise pelo BLAST-2-sequence do NCBI indica as regiões das seqüências que apresentam diversidade (Fig. 23).

\section{Sequence 1: lc1|EST002126 \\ Length $=1002(1$.. 1002)}

Sequence 2: 1c1|RC2-Pb30001-125H07

Length $=971(1 . .971)$
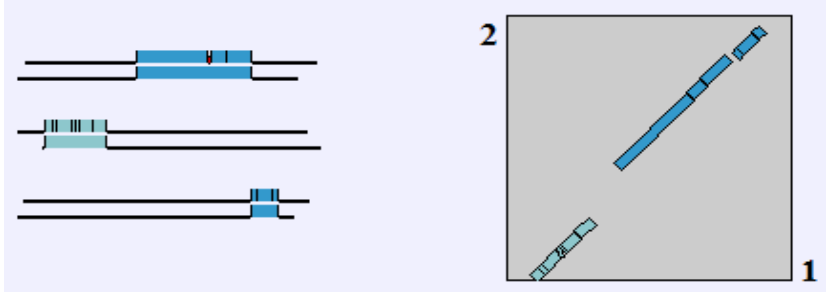

NOTE:Bitscore and expect value are calculated based on the size of the nr database.

NOTE:If protein translation is reversed, please repeat the search with reverse strand of the query sequence.

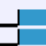

FIGURA 23: Comparação das seqüências das ESTs RC2-Pb30001-125H07-Pb18 e EST002126-Pb01. através da ferramenta BLAST 2 sequence do NCBI indicando presença regiões diferenciadas entre os dois isolados de $P$. brasiliensis.

Analisando os detalhes das seqüências de cDNAs dos dois isolados de $P$. brasiliensis podemos observar melhor esta diversidade (Fig. 24). Na seqüência da EST do Pb18 temos a presença de um microORF com 34 resíduos (comentada acima) em fase com a região 
codificadora da proteína PbPet100 enquanto que na EST do Pb01 não verificamos nenhuma, pelo menos não em fase.

>PbPET100 Pb18 (RC2-Pb30001-125H07)

AATTCCCGGGATGGAAGACGACGAGGCGCAGACTACAGAGAATATTTCCTGCGCaAATTGtGCCGCAATTCGA GAACCCCССTCTTCATATCCGTCCGTTCCATCTTTCGTGGATTCACTCGTTGCTTTGAATACATCGAACCCGT CCTATCGCTTGAACCCAGTTCGACACTGGTATCTCCTCCTGGAGTCCCCCGTCAGCACATCGCTTTCGCGGAA GCGAAAAAGACCAATATTTCTGTTCAGAAAAAAAGGGCCTCTCCTACACTTCACTTTTGAATACATGGGGAAA GTATAGAGGTATAAATGAAAAGAATTACCAGGCAGAAAGACCAGAAGGAAAGAAATAGAAGAACATATCAATC CACCTTCTACAACAAAATCCAAGACTACTGCAAAAGGAATATATAGCGAGATACGAACAAAGAAAGATACATG AGAGGAACCCCCGCGCATCTCTACTAATCAACAATGCTCAGCGCCATCCTCCGCAGGCTCCAAGGCGGGAACC TGGAAGTCTTCAAGTTCGGCATCTATATCCTTTTCCCCATCGGCTGCATGTACTACTTCGGCACAAACCTCGA AGAACGCTTCTCCGTCCCCGGCTACTGGCCCACGAAGGAGCAATCGCATAAGATTCCGATGGAGCTAGAGGAG ATTGAGAAGGAATTGGCACGCATGAATAAGCAGAAGGCGCTGAGGAGAGCGCAGCTGAAAGGGGAGAATGCCG AGAGCCAGAGTGGAAGTGGGAGTGGGAGTGGGAGIGCCGAGGCGGGTTCATGAAATGGATGTTGGAAACAACT GGGATGGTTGTATGTGGACGTTGTTTATGGGGTGTTTTAACTGGAGATCGGTAACATCTTTGCTCCTTCAATT CTCTTTCGTTTTATATATATAAATGGATGTGAGGATGCATTGTTAGATCGTGGATCTTAATTTGGCATGGGAT TGAGGAGTTGAGGAGTTTGAGATA GGATTTAATTCTTGTTCTTTTTAAAAAAAAAAAAAAAAAAAAAAAAAAAAA

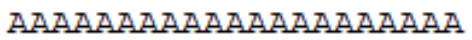

$>$ PbPET100 Pb01 (EST002126)

AACTAGTGGATCCCCCGGTGCTGCAGGAATTCGGCACGAGGACCAACTGAAAAGACAGCGGAAGCTGGAGGGA GAGAGTGCGCAGATACAGAAGTAATTCTGCCAATCGGCCGCAATTCGAGAACCCCTCTCTTTCATTTCCGTCC GTTCCATCTGTCGAGATTCGCTCGTTGCTTTGAATACATCGAACCCGTTCTATCGCTTGAACCCAGTTCGAAA CTGGTCTCCTCCTGAGTCCCCCGCAGCACATCGCTTTCGTGGAAGCGAAAAAGGGCAATATTTCTGTTCGAAA A.AAGGGCCTCTCCTACACTCCACTTTTGAATACATGGGGAAAGTACAAGAGGTATAAATGAAAAAGAATTACT AGGCAGAAAGAAAGACCAGAAGGAAAGAAATAGAAGAACATATCAATCTACCTCCTACAACACAATCCAAGGC GGGAACCTGGAAGTCTTCAAGTTCGGCATCTACATCCTTTTCCCCATCGGCTGGATGTACTACTTCGGCACAA ATCTCGAAGAACGCTTCTCCGTCCCCGGCTACTGGCCCACGAAGGAGCAATCGCATAAGATTCCAATGGATCT AGAGGAGATTGAGAAGGAATTGACACGCATGAATAGGCAGAGGGCGCTGAGGAGAGCGCAGCTGAAAGGGGAG AATGTCGAGAGTCAGGGTGGAAGTGGGAGTGGGAGTGCCGAGACGGATTCGTGAGATGGATGTTGGATGCAAC TGGGGTGGTTGTATGTGAACGTTGTTTATGGGGTGTTTTAACTGGAGATCGGTAACATCTTTGCTCCTTCAAT TCTCCTTCGTTATATATATATATATATATATATATAAATAGATGTGAGGATGCATTGTTAGATCTTGGATCTT AATTTGGCATGGGATTGAGGAGTTGAGGAGTTTGAGATAAGATTTAATTCTTGTTCTTTTTTTTGTTTTCCAT TTTAgGGGGTTTGCATATTGTGAATATATCTGTAGAGCCACTCCAGAAAAATTTAAAAAGACATGAAGCCCTT TAAAAAAAAAAAAAAA

FIGURA 24: Comparação das seqüências das ESTs RC2-Pb30001-125H07-Pb18 e EST002126-Pb01 indicando as regiões diferenciadas entre os dois isolados de P. brasiliensis. Presença de uma microORF na região 5’UTR em fase com a ORF codificadora da proteína PbPet100 do isolado Pb18. Ausência de uma repetição GGGAGT na região C-terminal da proteína no isolado Pb01 e a diferença de tamanho da repetição TA na região 3'UTR de ambos os isolados. 
Outra diferença é o tamanho da repetição (TA) observada na região 3'-UTR de ambos os isolados, sendo bem maior na EST do Pb01. Na região compreendendo a ORF referente à proteína $\mathrm{PbPet} 100 p$, além da diferença de tamanho, também observamos a ausência de uma repetição (GGGAGT) na seqüência do isolado Pb01. A observações obtidas sugerem que este gene PbPET100 representa mais um gene de $P$. brasiliensis que apresenta variações entre isolados.

O alinhamento das seqüências das proteínas PbPet100 dos isolados Pb01 e Pb18 com as proteínas homólogas e de outros organismos pode ser observados na figura 25. Existe grande variação na região C-terminal das proteínas. De acordo com Forsha et al., 2001 a porção C-terminal da proteína compreendendo os últimos 62 resíduos de aminoácidos são essenciais para a função da ScPet100p. Esta diversidade nesta região da proteína de $P$. brasiliensis em relação à proteína Pet100 de S. cerevisiae pode ser uma indicativa para explicar a ausência de complementação funcional da proteína PbPet100 na linhagem mutante de S. cerevisiae.

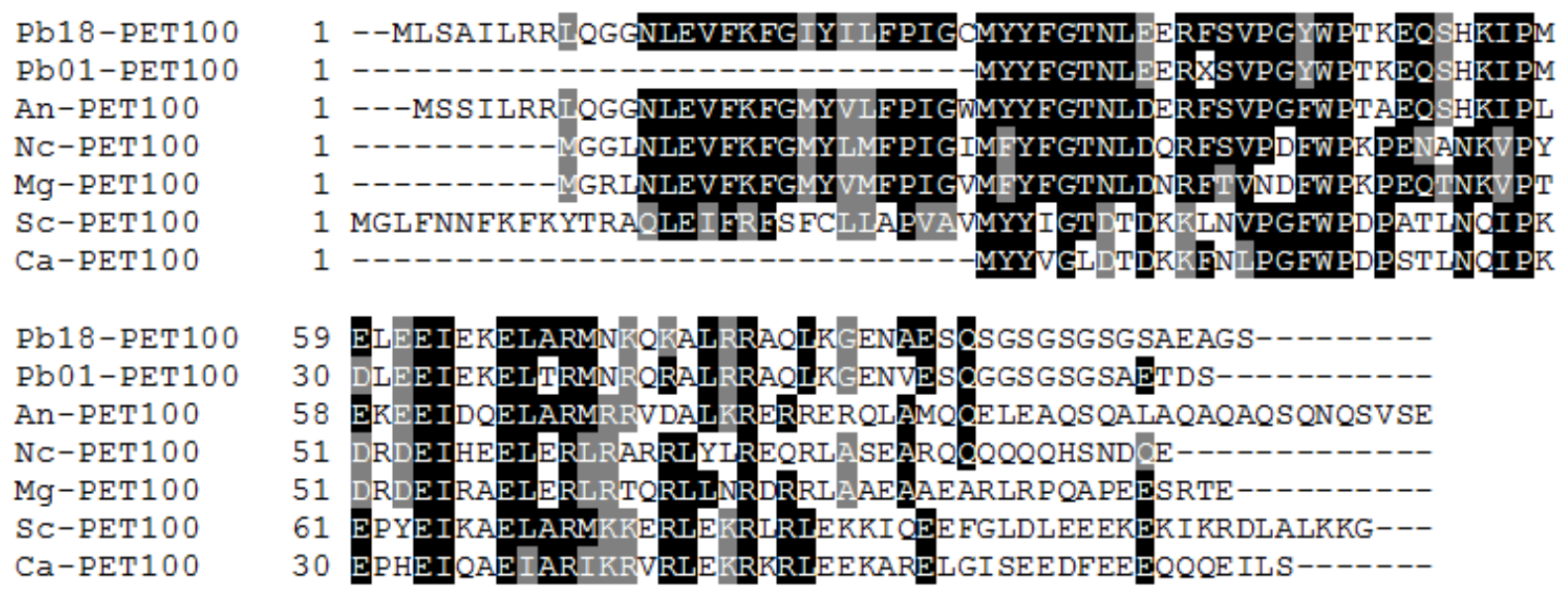

FIGURA 25: Alinhamento das proteínas PbPet100 dos dois isolados (Pb01 e Pb18) de P. brasiliensis (Pb) com as proteínas homólogas de Aspergillus nidulans (An), Saccharomyces cerevisiae (Sc), Neurospora crassa (Nc), Magnaporthe grisea (Mg) e Candida albicans (Ca). Resíduos de aminoácidos idênticos são pintados em preto e resíduos com características semelhantes estão em cinza. 
A análise quanto à presença de domínios característicos de hélices transmembrana indicou a presença de uma hélice de membrana nesta proteína (Fig. 26A), localizada na região N-terminal da proteína de $P$. brasiliensis.

\begin{tabular}{llllll} 
A & \# Pb18-PET100 & Length: 103 & \\
\# Pb18-PET100 & Number of predicted TMHs: & 1 \\
\# Pb18-PET100 & Exp number of AAs in TMHs: & 19.43571 \\
\# Pb18-PET100 & Exp number, first 60 AAs: & 19.43571 \\
\# Pb18-PET100 & Total prob of N-in: & \multicolumn{2}{l}{0.83713} \\
\# Pb18-PET100 & P0SSIBLE N-term signal sequence & \\
Pb18-PET100 & TMHMM2.0 & inside & 1 & 12 \\
Pb18-PET100 & TMHMM2.0 & TMhelix & 13 & 35 \\
Pb18-PET100 & TMHMM2.0 & outside & 36 & 103
\end{tabular}

TMHMM posterior probabilities for Pb18-PET100

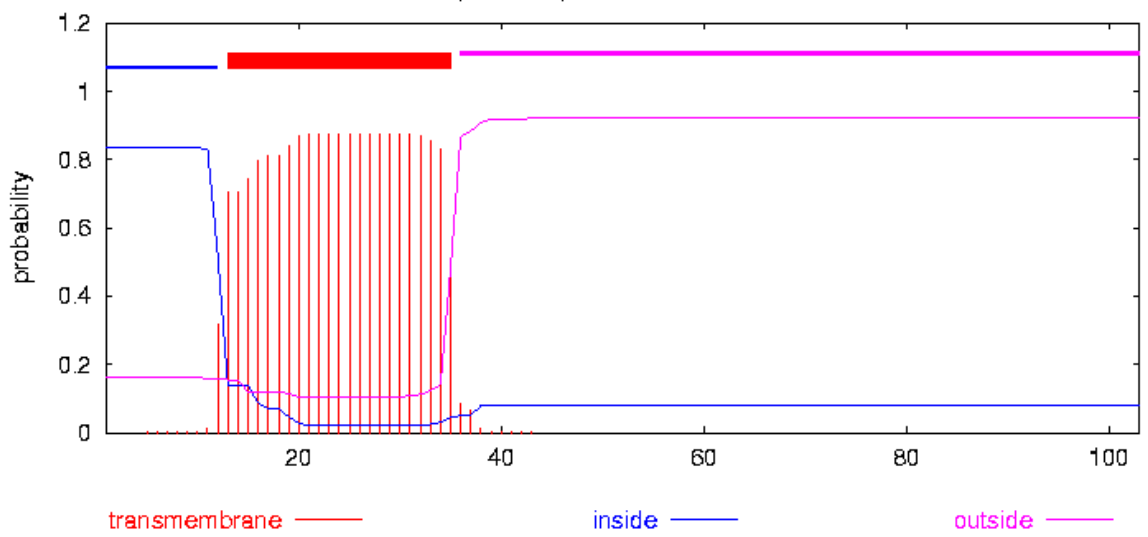

B \# Sc-PET100 Length: 111

* SC-PET100 Number of predicted TMHs: 0

SC-PET100 Exp number of AAs in TMHs: 16.63809

\# SC-PET100 Exp number, first 60 AAs: 16.63809

\# Sc-PET100 Total prob of $\mathrm{N}-$ in:

\# SC-PET100 POSSIBLE N-term signal sequence

SC-PET100 TMHMM2.0 outside 1111

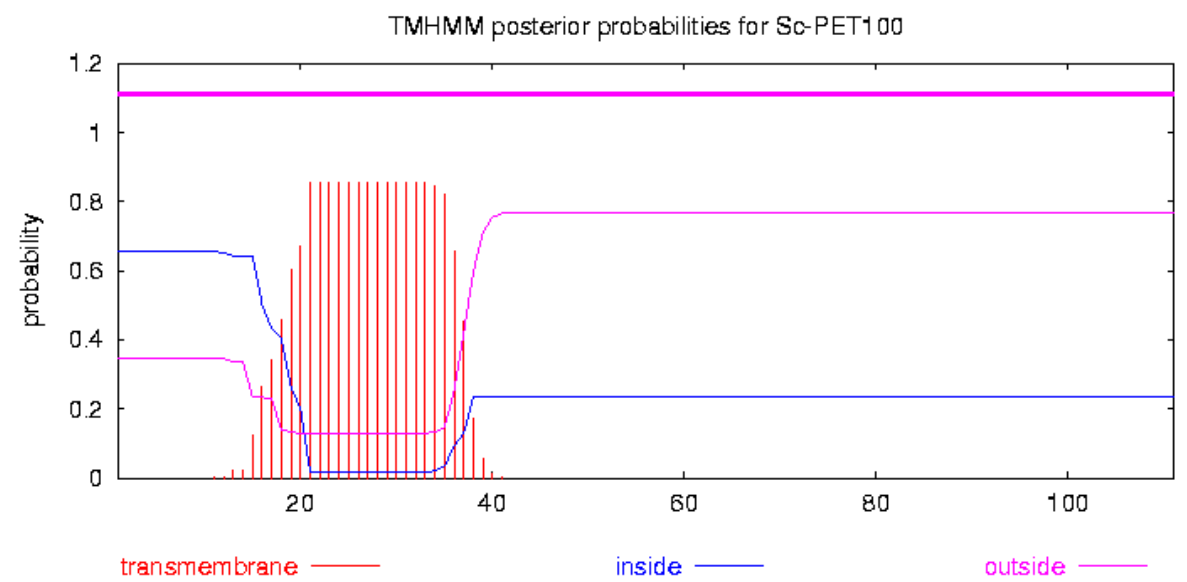

FIGURA 26A: Análise de resíduos característicos de hélices transmembrana na PbPet100p. obtida a partir da ferramenta TMHMM Server v. 2.0 disponível na página http://www.cbs.dtu.dk/services/TMHMM/. 26B: Análise semelhante com a proteína ScPet100p de S. cerevisiae. 
Esta mesma análise também identifica resíduos característicos de hélices de membrana na proteína ScPet100p de S. cerevisiae (Fig. 26B) entretanto nenhuma hélice é predita. De acordo com Church et al., (2005), a proteína ScPet100p de S. cerevisiae não está presente no citoplasma e na mitocôndria é predominantemente encontra na membrana interna, como uma proteína integral, não tendo sido localizada na matriz ou no espaço intermembranas.

As linhagens de S. cerevisiae com mutação nula do gene PET100 perdem a atividade da citocromo c oxidase devido à ausência dos citocromos a e a3, portanto, a proteína ScPet100p é requerida para a biogênese do complexo da citocromo c oxidase ativa. Entretanto, não é necessária para síntese, processamento ou transporte de subunidades da citocromo c oxidase para a membrana interna da mitocôndria e nem para a síntese do grupo heme A. Os estudos sugerem que a Pet100p não é requerida para a síntese ou localização das subunidades da COX na mitocôndria, mas é requerida em estágios posteriores na montagem do complexo indicando que a ScPet100p poderia estar atuando tanto na organização das subunidades como na montagem das mesmas no complexo da citocromo c oxidase funcional (Church et al., 1996).

A proteína ScPet100p embora não tenha sido encontrada como parte da holoenzima citocromo c oxidase foi identificada em um sub-complexo incluindo as subunidades VII, VIIa e VIII através de experimentos de sedimentações em gradientes de sucrose e, portanto embora se saiba que esta proteína seja necessária para a biogênese do complexo citocromo c oxidase funcional estudos futuros ainda deverão ser realizados para se determinar a função específica da mesma. Provavelmente esta proteína seja a primeira chaperonina envolvida na montagem do complexo da citocromo c oxidase identificada que não está participando da montagem do grupo heme A ou no recrutamento de íons cobre para a mitocôndria (Church et al., 2005).

\subsubsection{PbPET112}

Para estudarmos o gene PET112 de P. brasiliensis homólogo da proteína Pet112p de S. cerevisiae selecionamos a EST-VP1-Pb30001-203E03 (Goldman et al., 2003). O seqüenciamento completo do inserto deste clone foi realizado utilizando-se a técnica de inserção de transposons. O cDNA completo é constituído de aproximadamente 2003bp. A fase aberta de leitura correspondendo à proteína PbPet112p é constituída por 603 resíduos de 
aminoácido e foi identificada utilizando-se a ferramenta ORFfinder do NCBI. Esta ORF compartilha 32\% de identidade com a proteína Pet112p de S. cerevisiae e contém os domínios conservados (GatB) da família de proteínas Pet112p (Fig. 27).

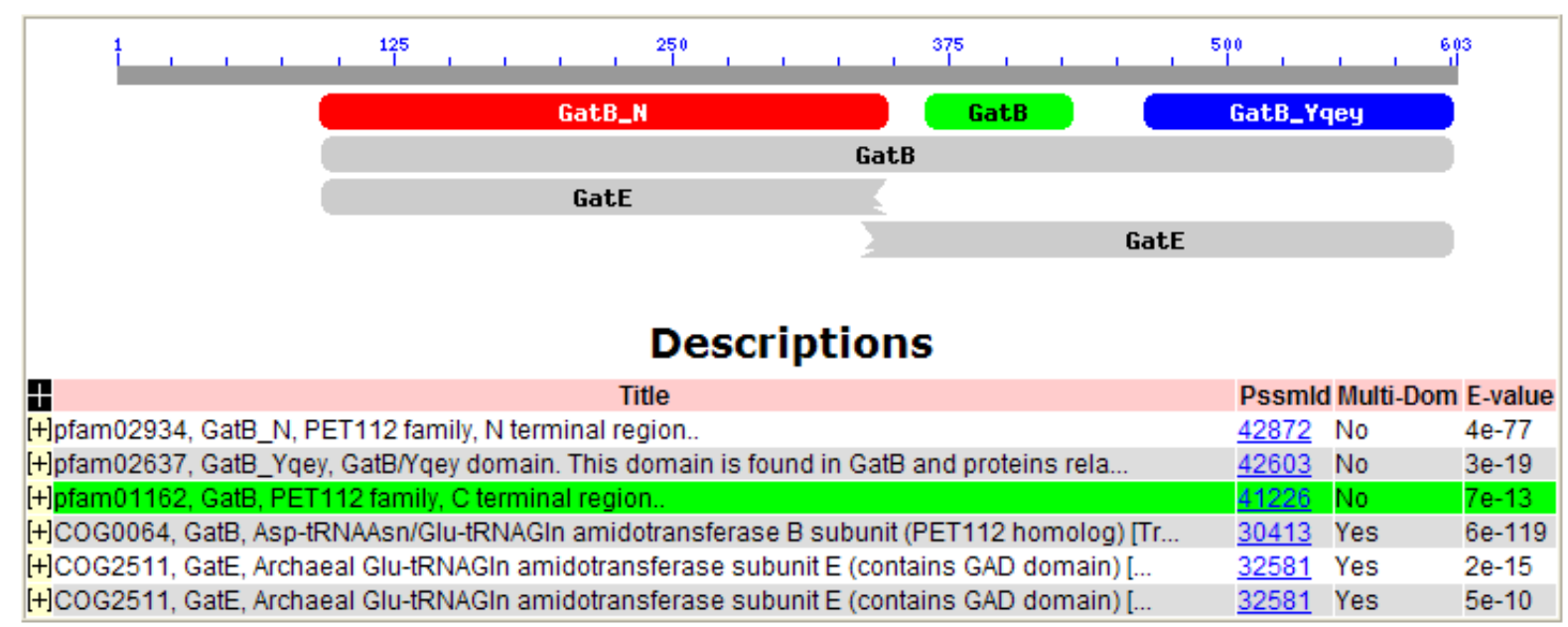

FIGURA 27: Alinhamento por BLASTp da ORF referente a proteína Pet112p de P. brasiliensis. identificada na EST-VP1-Pb30001-203E03. A figura mostra os domínios conservados da família de proteína Pet112.

Uma análise de seqüência peptídica da PbPet112p, utilizando a ferramenta EditSeq do programa DNASTAR indica que esta proteína possui uma massa molecular de aproximadamente 66,7KDa. As seqüências nucleotídica e peptídica referente à PbPet112p foram depositadas no bancos de dados do GenBank/NCBI com o número de acesso DQ402183.

Para excisão desta ORF direcionada para clonagem em vetor de expressão de $S$. cerevisiae utilizou-se as enzimas KpnI e XbaI. Ambos os sítios estando presentes nas extremidades adjacentes do plasmídeo original de clonagem (pCMV-Sport6 da Invitrogen). A digestão foi realizada de acordo com as instruções do fabricante (New England Biolabs). O fragmento KpnI/PbPET112/XbaI foi separado em gel preparativo 1\% agarose e recuperado do gel por eletroeluição, seguido de purificação por extração com fenol e éter e precipitação com etanol. O fragmento purificado KpnI/PbPET112/XbaI foi ligado no vetor de expressão pMGL4, previamente linearizado com as mesmas enzimas e tendo as extremidades 5' defosforiladas pela enzima CIP -Calf Intestine Phosphatase. O recombinante foi então selecionado por transformação da mistura de ligação em E.coli DH10B competente seguido de análise por seqüenciamento dos pDNAs isolados dos transformantes.

O gene PET112 está envolvido no processo de síntese protéica mitocondrial e conseqüentemente o mutante $a W 4741 \Delta p e t 112 / M H L U$ possui o genoma mitocondrial muito 
instável. Embora, várias tentativas de se isolar uma linhagem mutante de pet112 contendo o mtDNA íntegro tenham sido realizadas este objetivo não foi atingido, portanto, os testes de complementação funcional do gene $P b P E T 112$ em mutantes de $S$. cerevisiae também não foram realizados.

A complementação heteróloga funcional em mutantes de gene em S. cerevisiae já foi obtida com a proteína homologa Pet112p da bactéria B. subtilis (Kim et al., 1997).

O gene nuclear PET112 foi identificado em S. cerevisiae atravez da análise de um mutante (pontual) pet112 que apresenta uma inibição na concentração da Cox2p enquanto que o nível de mRNA para o gene COX2 no mutante pet112 apresenta-se normal. Deleção do gene PET112 em S. cerevisiae desestabiliza o genoma mitocôndrial, sugerindo que esta proteína possa estar envolvida na síntese protéica da mitocôndria (Mulero et al., 1994).

Em uma busca por seqüências relacionadas ao gene PET112 nos bancos de dados de ESTs, Petruzzella e colaboradores (1998) identificaram um cDNA no genoma humano que possui uma fase de leitura correspondendo a homologa desta proteína (Pet112-like) em que compartilha $30 \%$ de similaridade com a proteína Pet $112 p$ de S. cerevisiae. Testes de complementação funcional com esta proteína (Pet112-like) humana ainda não foram descritos.

Nenhum domínio de hélice transmembrana foi identificado nesta proteína de $P$. brasiliensis ou em S. cerevisiae.

O alinhamento da proteína Pet112p identificada em P. brasiliensis com as homólogas de outros fungos e com a proteína Pet112 da bactéria B. subtilis (Fig. 28) indica um bom nível de conservação da PbPet112p em várias regiões entretanto há várias regiões onde não existe semelhança alguma. Se considerarmos a importância da região N-terminal na complementação heteróloga, podemos perceber que há pouca ou nenhuma semelhança nesta região entre as proteínas de $P$. brasiliensis e de $S$. cerevisiae, ao contrário do que ocorre entre as proteínas de $S$. cerevisiae e B.subtilis (que são funcionalmente intercambiáveis) existindo alta similaridade nesta região (Fig. 28). 


\section{PbPET112}

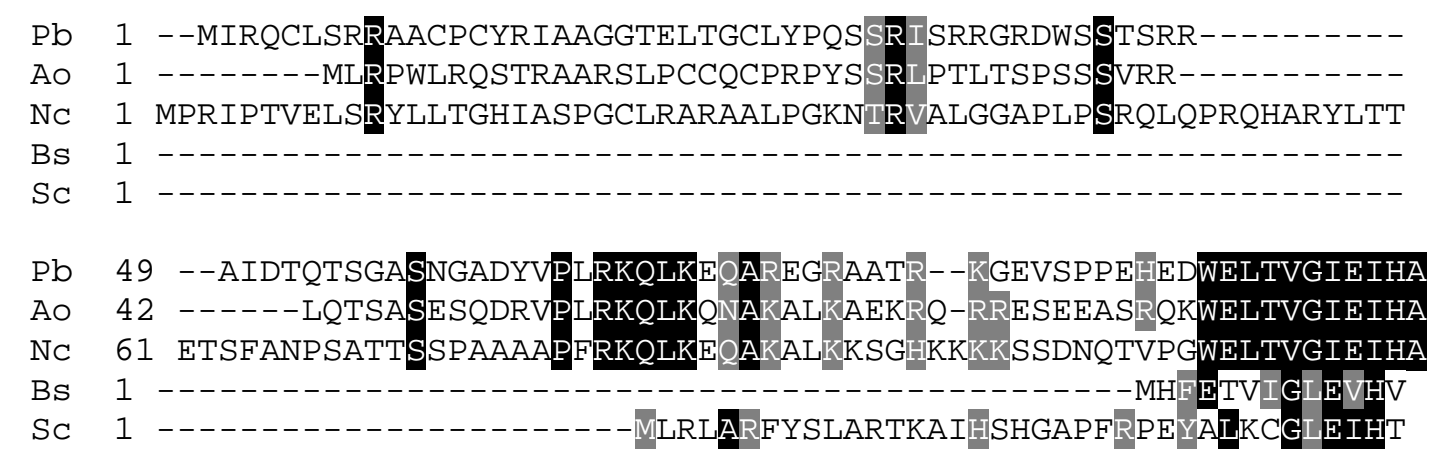

Pb 105 QLDTDTKLFSRAS- - -AAIDDVPNSNVALFDIALPGSQPLFQPATLIPALRAAIALNCDV Ao 95 QLNTETKLFSRAS - - -TSSTDLPNSNVALFDLAFPGSQPEFQVPTLLPALRAALALNCDI NC 121 QLNTAHKLFSPAT - - TSFNDPPNTHVAPFDLALPGSQPLFQPATLIPAVRAALALNCSI BS 14 ELKTDSKMFSPSP - - AHFGAEPNSNTNVIDLAYPGVLPVVNRRAVDWAMRASMALNMDI Sc 38 QLNTKNKLFSQSTNSATSLVDAPNHHTSYYDIALPGTQPVLNLEAILFAMKLSLALGSQV

Pb 162 QRVSRFDRKHYFYQDQPAGYQITQYYEPYAKNGSTWLGPHDGIAKEDGVGVKIGIKQIQL Ao 152 QPVSRFDRKHYFYQDQPAGYQITQYYEPFARNGYVDLFGYDGIAPEDGDHVRIGIKQVQL NC 178 QPVSRFDRKHYFHWDQPSGYQITQFYEPFAKDGFITLYARDGIAAEDGEEIKVGIKQVQM BS 71 ATNSKFDRKNYFYPDNPKAYQISQFDQPIGENGYIDIEVDG - - - - - - ETKRIGITRLHM Sc 98 NSISQFDRKHYFYGDQPQGYQLTQHYRPFARGGKINLSKELDDIDES - -AKEIGILQLQI

Pb 222 EQDTAKSQELPSS - - TYLLDFNRVSRPLIEIITLPQIHSPATAAACVRKIQTILQSVGA Ao 212 EQDTAKSQEYHPS - - TQLLDFNRVSHPLVEIITMPQIHTPATAAACVRKIQAILQSCSA NC 238 EQDTAKTTAQPGD - - -VQWLDFNRVGVPLIEIITLPEIHHPATAAALVRKVQMVLASVDA BS 124 EEDAGKSTHKDG - - - YSLVDLNRQGTPLIEIVSEPDIRSPKEAYAYLEKLRSIIQYTGV Sc 156 EQDTGKSHYTETDKDVITLVDLNRSNVPLIELVTKPDFSDIKQVRAFIKKYQNLVRHLHI

Pb 279 VTTGMEMGGLRADVNVSVRKRSEGVGDHQYHGITGLGQRTEIKNLSSFKAVENAIIAERD Ao 269 VTTGMELGGLRADVNVSIRQRGDTEGVHQYGGIGGLGQRTEIKNLSSFKAVEDAIIAEKN NC 295 CVSGLEEGGLRADVNVSVRRTDDPS- - - - - - GKLGTRTEIKNLSSFKAVEDAIIAERD BS 180 SDCKMEEGSLRCDANISLRPYGQKE- . - . - . FGTKTELKNLNSFNYVKKGLEYEEK Sc 216 SSGDLETGAMRVDVNLSINEYARVE- - - - - - - LKNLPNTS - - - - SIINAIKYEYQ

Pb 339 RQIAVLRAGGA - - -IEGETRGWTLGSTETRKLRGKEGEVDYRYMPDPDLGPVIIGIDVFF Ao 329 RQIAVLESGGV - - - VEGETRGWTIGSTETRRLRGKEGEVDYRYMPDPDLPPLLIGADLVS NC 347 RQIELLEEGGE - - -VKGETRGWSLGSTETRRLRGKEGEVDYRYMPDPDLGPVVIGEDLVA BS 230 RQEEELLNGGE - - IGQETRRFDESTGKTILMRVKEGSDDYRYFLEPDIVPLYVDEDWKA Sc 260 RQVELISVGDTSSLMEPETRGWTG - -SSTVKLRSKETTIDYRYMPDPELPYINLAPDVIS

Pb 396 ELKAKLPVLPDALLQSLVQDPKYGLSTDDAKALIELDDGDRLDYYKDAVDILITLQKDLS Ao 386 ELANTLPTSSDELIG-LLTGKEYGLSIEDAKPLVELEDGARLEYYQDVVDILRDLQQDQD NC 404 RLRETMGVLPDQEAD - -QLMERYNLSAKDALSLMLLDGGARIQYFYNVLDSLEERLVADG BS 287 RVRETIPELPDERKA - -KYVNDLGLPEYDAHVLTLTKEMS - -DFFEGAIDHGADVK - - - Sc 318 GVRGLMPQLPDDIMR-ILMKKPYQLSLKDAKILTYNSNQND-MYNHEALRSYYLDTFREF

Pb 456 DDFSGGGK - - VVGNWVLHELGGLLTKSN - . . . . . . . - - LHWDSERVPAQSLAE Ao 445 PKSRGGLAR - -VAGNWVLHELGGLLTKAD - . $\ldots \ldots$ NC 462 QAVPEGAEHATLAANWCLHELGKLTDSASSSSCSDPDVLEGLAMTPLGESPLVPSSSLAA BS $339 \ldots \ldots$.......... Sc 376 SKLAGERSNAKLPTNWI IHEFLGDLNKLQIP . . . . . . . . - LAKAKEILAPPVFAQ

FIGURA 28: Alinhamento da PbPet112p de P. brasiliensis (Pb) com as proteínas homólogas (continua) 


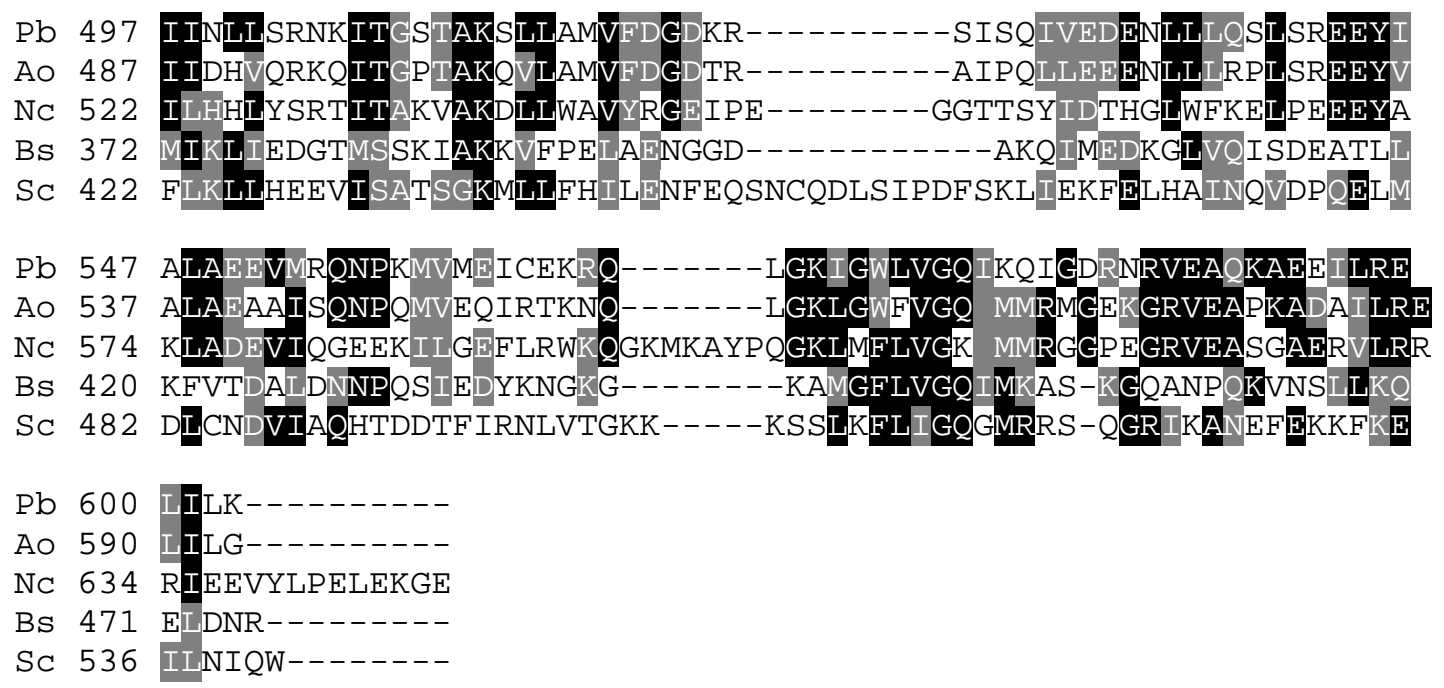

FIGURA 28: Alinhamento da PbPet112p de P. brasiliensis (Pb) com as proteínas homólogas (continuação). Aspergillus oryzae (Ao), Neurospora crassa (Nc), Bacillus subtilis (Bs) e Saccharomyces cerevisiae (Sc). Resíduos de aminoácidos idênticos são pintados em preto e resíduos com características semelhantes estão em cinza. 


\subsubsection{PbPET191}

Usando a seqüência da proteína Pet191 de Saccharomyces cerevisiae como sonda para identificação de EST e RSTs no banco de dados de $P$. brasiliensis identificarmos somente um clone de ESTs (EST013844) que apresentou similaridade significativa. O clone correspondente a esta EST pertence à biblioteca do consórcio da região central do Brasil (Felipe et al., 2003). Entretanto este clone não foi utilizado devido a falha de obtenção da excisão do plasmídeo (pBluescript do fago lambda) contendo esta EST embora tenhamos realizado este procedimento com sucesso em várias outras amostras. Análise de comparação por BLASTn da seqüência da EST013844 contra o banco de $P$. brasiliensis também não identificou nenhum outro clone com similaridade significativa. Portanto, para o estudo deste gene, a estratégia utilizada foi a clonagem da região codificadora a partir de amplificação direta do DNA genômico por PCR utilizando-se os óligo nucleotídeos específicos (senso: 5'CGTGCGGAGCTCGATTGTGTT-3’ e anti-senso: 5'-TCCGTTCTGCAGCTCCCCC-3’), desenhados com base na seqüência da EST013844. Ao desenhar os oligos iniciadores inseriuse os sítios de reconhecimento das enzimas SacI e PstI nas extremidades 5' e 3’ da região codificadora do gene PbPET191. A amplificação por PCR foi realizada a partir de DNA genômico de $P$. brasiliensis nas seguintes condições: Uma desnaturação inicial de $94{ }^{\circ} \mathrm{C}$ por 4 minutos, seguido por 35 ciclos de: desnaturação a $94{ }^{\circ} \mathrm{C}$ por 1 minuto; anelamento dos oligos iniciadores a $55{ }^{\circ} \mathrm{C}$ por 30 segundos e extensão a $72{ }^{\circ} \mathrm{C}$ por 1 minuto. Após os 35 ciclos seguiu-se mais 10 minutos a $72{ }^{\circ} \mathrm{C}$ e finalmente resfriamento a $4{ }^{\circ} \mathrm{C}$.

O produto amplificado ( 640 bp) foi submetido à dupla digestão com as enzimas SacI e PstI seguindo as condições do fabricante (Fermentas Life Sciences). O produto da digestão foi purificado e ligado no vetor pMGL3 previamente digerido nas mesmas condições e tendo suas extremidades 5' desfoforiladas com a enzima CIAP - "Calf Intestine Alkaline Phosfatase”. A ligação seguiu o protocolo do fabricante (Promega). A mistura de ligação foi inserida por transformação na bactéria E.coli $\mathrm{DH}_{10} \mathrm{~B}$ competente, preparada pelo método de Cloreto de Cálcio. Obtivemos vários transformantes sendo coletados aleatoriamente cerca de dez (10) deles para extração e análise de seus insertos por seqüenciamento. Dos dez transformantes analisados somente um, continha o fragmento genômico referente ao gene PbPET191. O produto da amplificação foi clonado diretamente no vetor de expressão pMGL3 como o objetivo de realizar o ensaio de complementação heteróloga direta (a partir do DNA genômico) no mutante de $S$. cerevisiae. Entretanto, uma análise por BLASTn da seqüência consenso obtida contra a seqüência da EST013844 revelou a presença de dois íntrons 
interrompendo a região codificadora deste gene de $P$. brasiliensis. Portanto, inviabilizando o ensaio de complementação funcional, que não foi realizado até o momento com este gene.

Os motivos canônicos de borda intrônica (5’ GT...AG 3') que interrompem o gene PbPET191 podem ser observados na figura 29. A proteína PbPet191p predita a partir da seqüência de nucleotídeos é constituída por 123 resíduos com massa molecular estimada de 13.1 KDa.

O alinhamento da seqüência da proteína PbPet191p com as homólogas de outros organismos indica que esta proteína é altamente conservada entre os fungos (Fig. 30) entretanto, com a proteína de $S$. cerevisiae o grau de similaridade é bem menor.

O gene PET191 identificado e caracterizado (McEwen et al., 1993) como codificador de um fator de montagem do complexo da citocromo c oxidade devido à capacidade de restaurar a deficiência respiratória de mutantes respiratórios de S. cerevisiae. Entretanto, ainda não foi definida nenhuma função específica para está proteína. Pela escassez de EST (uma) encontrada nos bancos de dados de $P$. brasiliensies deve ser um gene pouco expresso entretanto é bem conservado entre os fungos analisados (Fig. 30).

Um estudo feito entre 53 pacientes, com deficiência da citocromo c oxidase, analisaram a presença de mutações em três genes (COX16, COX19 e PET191) relacionados com atividade da COX entretanto, não foram identificadas nenhum tipo de mutação nesses três genes que pudessem ser responsáveis pela deficiência (Tay et al., 2004).

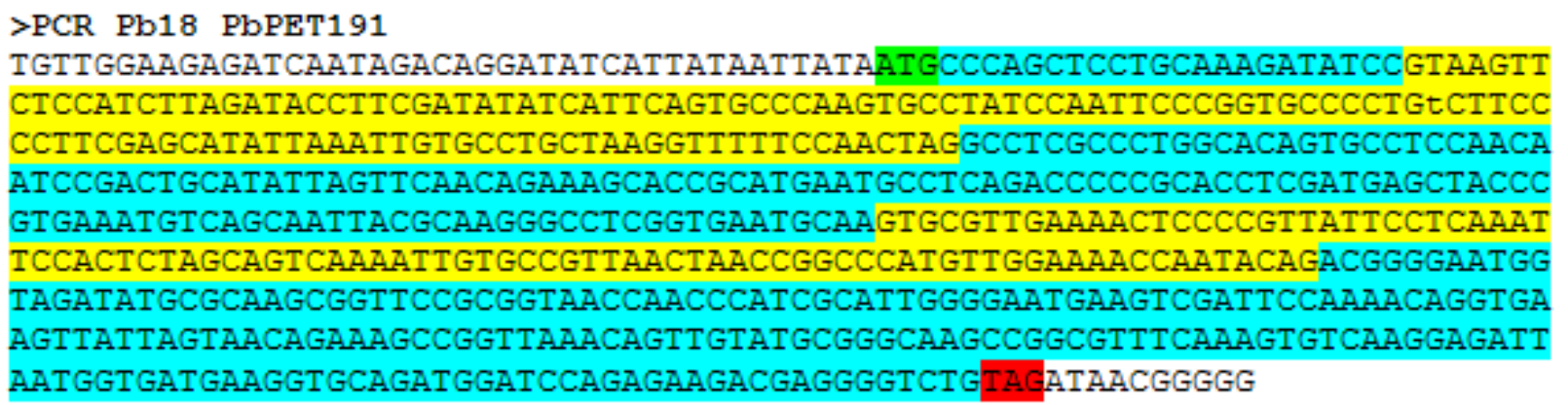

FIGURA 29: Análise da seqüência consenso do inserto da construção pMGL3/PbPET191. indicando a região codificadora do gene PET191 de P. brasiliensis bem como os introns e as bordas intrônicas (5' GT...AG 3'). 


\section{PET191}

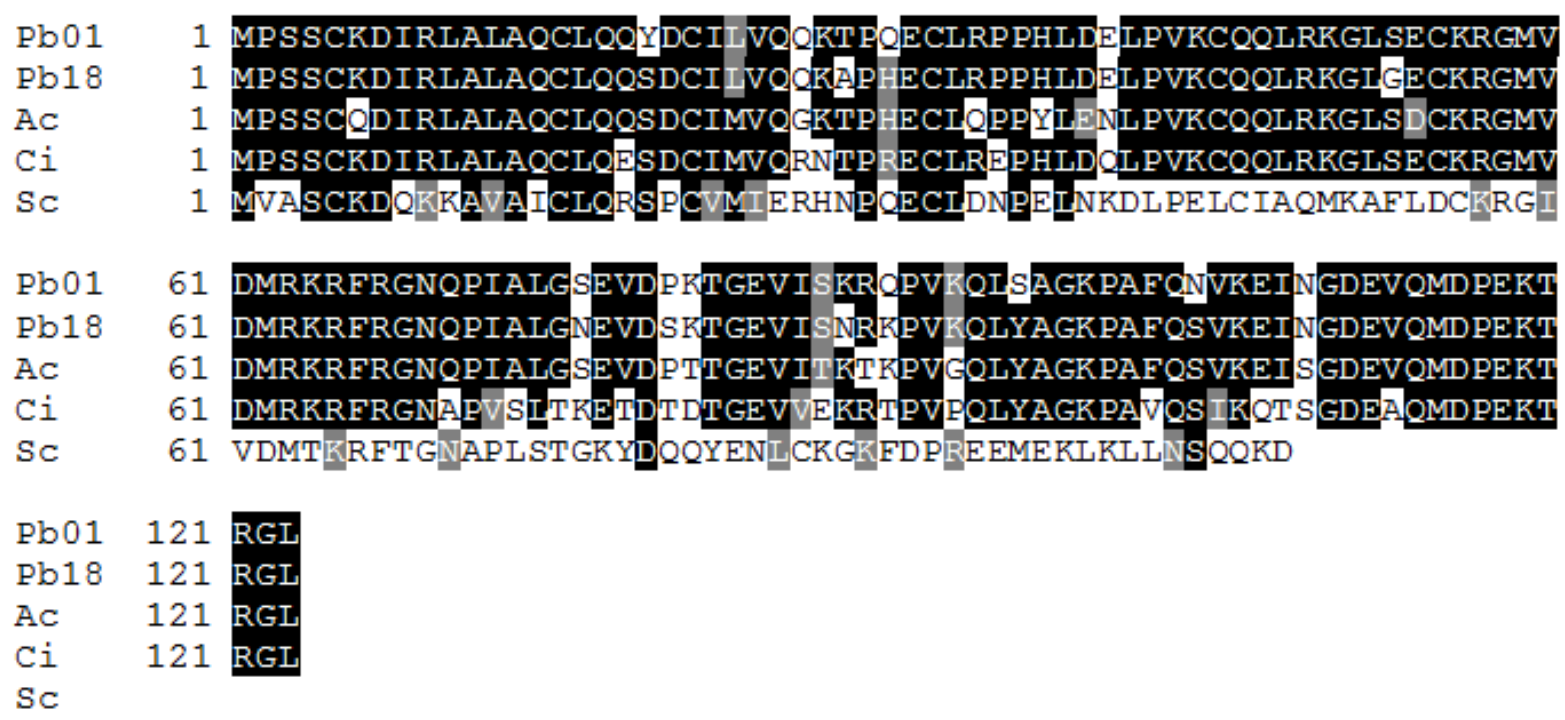

FIGURA 30: Múltiplo alinhamento das seqüências das proteínas Pet191p de Paracoccidioides brasiliensis. dos isolados Pb18 e Pb01 com as proteínas homólogas, de Ajellomyces capsulatus (Ac), Coccidioides immitis (Ci) e Saccharomyces cerevisiae ( $\mathrm{Sc}$ ). Resíduos de aminoácidos idênticos são pintados em preto e resíduos com características semelhantes estão em cinza.

\subsubsection{PbMSS51}

Utilizando a seqüência da proteína Mss51p de Saccharomyces cerevisiae em análise comparativa de seqüências através da ferramenta tBLASTn identificamos nos bancos de dados de ESTs de Paracoccidioides brasiliensis várias ESTs apresentando alto nível de similaridade com a proteína da levedura S. cerevisiae. Para o estudo do gene PbMSS51 de $P$. brasiliensis selecionou-se o clone de EST-VP1-Pb00001-166F10 que pertence à biblioteca do consórcio paulista (Goldman et al., 2003). O inserto deste clone foi inteiramente seqüenciado através da técnica de seqüenciamento por inserção de transposons e a seqüência completa do cDNA consiste de aproximadamente 1774bp. Utilizando a ferramenta ORFFinder do NCBI identificou-se uma fase aberta de leitura referente à proteína Mss51p de P. brasiliensis que é constituída de 514 resíduos. Esta ORF compartilha 38\% de identidade com a proteína ScMss51p (Tabela 4). As seqüência nucleotídica e peptídica deste gene de P. brasiliensis foram depositadas no GenBank/NCBI com número de acesso DQ003715.

Por análise do mapa físico de restrição da seqüência completa do cDNA utilizando-se a ferramenta nebcutter da New England Biolabs, identificou-se os sítios para as enzimas KpnI e XbaI nas extremidades 5' e 3' da região da ORF que excisão a ORF direcionado para a 
construção do recombinante com o vetor de expressão pMGL4 de S. cerevisiae. A digestão seguiu as instruções do fabricante (New England Biolabs) das enzimas e após a digestão com as respectivas enzimas de restrição o fragmento $\mathrm{KpnI} / \mathrm{PbMSS51/XbaI}$ foi isolado em gel preparativo 1\% agarose e recuperado do gel por eletroeluição, seguida de purificação por extração com fenol e éter e precipitação com etanol. O fragmento purificado foi ligado no vetor de expressão pMGL4 previamente linearizado com as mesmas enzimas e tendo as extremidades 5' defosforiladas pela enzima CIP -Calf Intestine Phosphatase. O recombinante foi então selecionado por transformação da mistura de ligação em E.coli DH10B competente seguido de análise por dupla digestão com SacI/PstI e seqüenciamento dos insertos dos pDNAs isolados dos transformantes. O recombinante selecionado pMGL4/PbMSS51 foi então inserido por transformação no mutante deficiente respiratório de $S$. cerevisiae aW4741Amss51/MHLU seguindo o método de LiOAc. Os transformantes obtidos foram selecionados em meio mínimo de cultura (WO) devidamente suplementado e a capacidade de restauração da função respiratória dos transformantes com o PbMSS51 foi analisada em meio de cultura contendo etanol e glicerol como fonte de carbono (EG). Neste caso, mesmo após longo período de incubação a $30{ }^{\circ} \mathrm{C}$ longo não obtivemos sucesso na complementação funcional.

O alinhamento da PbMss51p com as proteínas homólogas de outros fungos incluindo S. cerevisiae (Fig. 31) apresenta algumas características da proteína predita Mss51p de P. brasiliensis que explicaria a não complementação funcional no mutante de $S$. cerevisiae utilizado.

Embora a PbMss51p compartilhe de 38\% de identidade com a Mss51p de S. cerevisiae entretanto, a Mss51p de $P$. brasiliensis possui 78 resíduos a mais, sendo que estes resíduos são encontrados na forma de inserções, tanto na região N-terminal (supostamente uma região de endereçamento da proteína PbMss51p para a mitocôndria e, portanto, crucial no que diz respeito ao desempenho de sua função) quanto em regiões conservadas da proteína o que conseqüentemente estaria atuando na estrutura tridimensional da proteína Mss51p de $P$. brasiliensis suficientemente para impedir as interações necessárias com seus alvos em $S$. cerevisiae. Quando observamos a comparação destas proteínas (PbMss51p e ScMss51p) podemos observar que os 78 resíduos extras da PbMss51p estão distribuídos em inserções ao longo da proteína da seguinte maneira: 25 resíduos extras na PbMss51 entre os resíduos 33 e 34 de $S$. cerevisiae; 12 resíduos entre os resíduos 42 e 44; 28 resíduos entre os resíduos 87 e 88 e 7 resíduos de $P$. brasiliensis entre os resíduos 298 e 299 de S. cerevisiae (Fig. 31). 
A proteína Mss51p de S. cerevisiae foi inicialmente identificada (Faye et al., 1983) como sendo requerida para a maturação Cox1p. Este gene também já foi identificado em outros organismos além de fungos, inclusive no reino animalia como Drosophila virilis e Apis mellifera. Barrientos et al., 2004, mostram que a proteína Mss51p de S. cerevisiae atua tanto como fator de indução de transcrição quanto como fator de elongação durante a tradução da proteína Cox1p na mitocôndria. Segundo o autor, a Mss51p juntamente com a proteína Cox14p formariam um complexo transiente com a proteína Cox1p recém sintetizada e a liberação de Mss51p que atuaria na indução de nova transcrição de COX1 estaria dependente do próximo estágio de montagem da citocromo c oxidase, provavelmente envolvendo a proteína ShyIp (Barrientos et al., 2002).

Como este gene de certa forma está envolvido no processo de síntese protéica mitocondrial, poderíamos desconfiar da instabilidade do genoma mitocondrial desta linhagem mutante (a4741 $\Delta m s s 51 / M H L U$ ) desde que segundo Myers e colaboradores (1985), mutantes de genes nucleares envolvidos na síntese protéica mitocondrial de $S$. cerevisiae, induzem a instabilidade deste genoma e isso se reflete na geração espontânea de petites, ou seja, linhagens com grandes deleções ou perda total do genoma mitocondrial. Entretanto essa possibilidade foi descartada através da análise de cruzamento da linhagem mutante (a4741 $\Delta m s s 51 / M H L U)$ com a linhagem $\alpha \mathrm{KL} 14 \rho^{\circ}$, que não apresenta DNA mitocondrial. Os diplóides deste cruzamento cresceram em meio contendo etanol e glicerol como fontes de carbono, indicando que o genoma mitocondrial da linhagem mutante a4741 $\Delta$ mss51/MHLU está funcional. Assim, como a proteína de S. cerevisiae, a proteína Mss51 predita de P. brasiliensis também não apresenta nenhum domínio característica de hélice transmembrana. 
MSS51

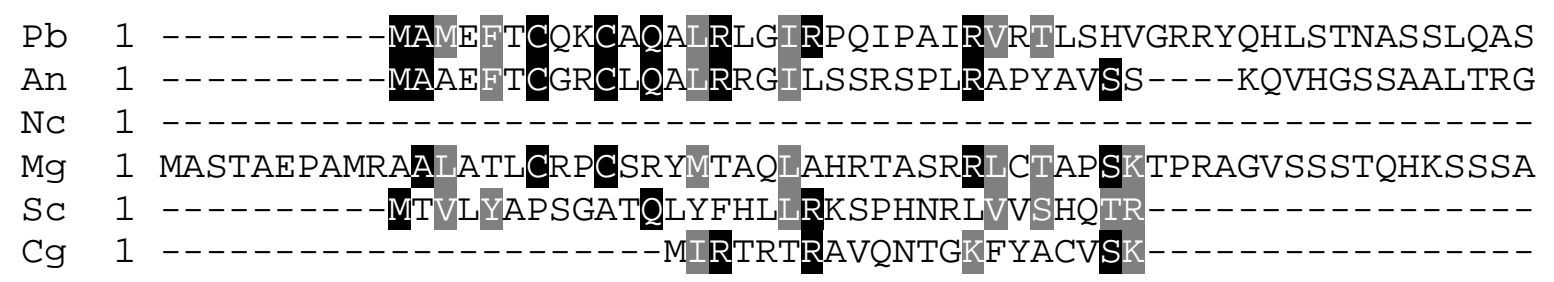

$\mathrm{Pb} 51$ KAGSWSTKVRTETTTITNVASLSASQPTTSGTSEAYNGRPLLQPHNLFHSYSNSPSPEIR An 47 LESRRSSRYLLAPKLASLPTAAPIIQKATSATSNGPNSRPLLKPNNLFHDFTQSPSPEIR NC 1 ( $\ldots \ldots \ldots \ldots$ Mg 61 PLVCQHEAARSSSPAGPVRKSYAKYSSSAAAAAAPSKPETKLSQDDLFHPMSESPIPSMR SC 34 -..--RHLMGFVR--..--N- -ALGLDPPPSPEDPTPENRFHPWDQSPSVDLR Cg 22 - - - - RQLMGFVR - - - - N-ALGLDPPPSPDEPTEQNRFHPWDQSPAVDLR

Pb 111 QRAAFIVQNAFCPHPSHRRTRVPTSPHDSEARKSPEASSDSQPPLHSQFECPDCGVPIYC An 107 QRAAFIKQNAFCPHPSHQQTRVPVSPHDPESRKS - - LTNASLPPAHSHFECPDCGIPIYC NC 1 . $\ldots$ Mg 121 QRAAYIRQHAYCPHPDHRMSRVTPDGEVQPPAEN - - - - ATQSPAHVDFECPDCGVPVYC Sc 74 ERAAKIRTLAHCP. - . Cg 62 ERAARIKTLAKCP - .

$\mathrm{Pb} 171$ SEEHWMDDFEAH-LEVCDTIRQINEDDHDLRSGRFFSEFNYPGPQEEESIVNMTNWDTFL An 165 SEGHWMDDFEAH-LEVCETLRQINEDDHDLRSGRFFPEFVMPGLQDENFVINMTNWDTFL NC 1 Sc 106 SREAWEMDKAYHDSKKYEILKKVNIYEHDLRSGRPFPEFDFPQQQGYDKAVNLTNWDLFF Cg 94 SREAWEQDKEYHASKKYEILKKVNIYEHDLRSGRPFPEFDFPRDQGPDRTVNLTNWDLFL

Pb 230 YTRQFDAINNDRNMRQVTRLLTYPVTIASVLHELSPYHIRKGGRLTPEGLKSLSALRYTL An 224 YTREFDAINDDRSMRQVTRMLTYPLTIGSVLHELSPYSIRKNQRLTTEGLKSVSALRYSL NC 1 - . - - -NDDRCMRQATRLLTYPLTIGSVLHELSPYHIRN - -RLTVEGLKSLTALRYTL Mg 235 YTRAFNAINSDRGMRQATRLLTYPVTIGSVLHELSPYNIRKGGRLTTEGLKSFSALRYTL SC 166 YTRSFYSMDTEFQLAAVTKMLSYPITIGSLLHKFSPYSLNPKGPITLEGLKSLAALRYTL Cg 154 YTRSFYSMDTEFQLAAVTKMLSYPITIGSVLHQFSPYSLNPKGPITLEGLKSLAALRYTL

$\mathrm{Pb} 290$ HPPKTGEGAAMSGLRLKAPPVRIFILGARAESSLPRDVWLQLSYLFPRALISLIFIGPES An 284 HPPRTGEGVDIQGLRVKAPPVRIFILGARAESSLPRDVWLQLSHIFPRSLIHLIFIGPES NC 51 HPPKTGGNESIKGLRPEAPPVRVFILGARAESSLPRDAWVQLAHLFPLSR LHLIFIGPES Mg 295 HPPRSGGDGSVKGLRPEAPPARIFVLGARAESSLPRDVWVQLAHLFPRQRLHLIMIGPES SC 226 YPLENRS --LPT--TTKNRAMRIFILGARAEAQLPGHVWKQLQFLFPEQSFEIHFIGPEC Cg 214 YPLQNRA--VTT-TAKNKPMRIFILGARAEAQLPGHVWKQLQFLFPQQNFETHFIGPES

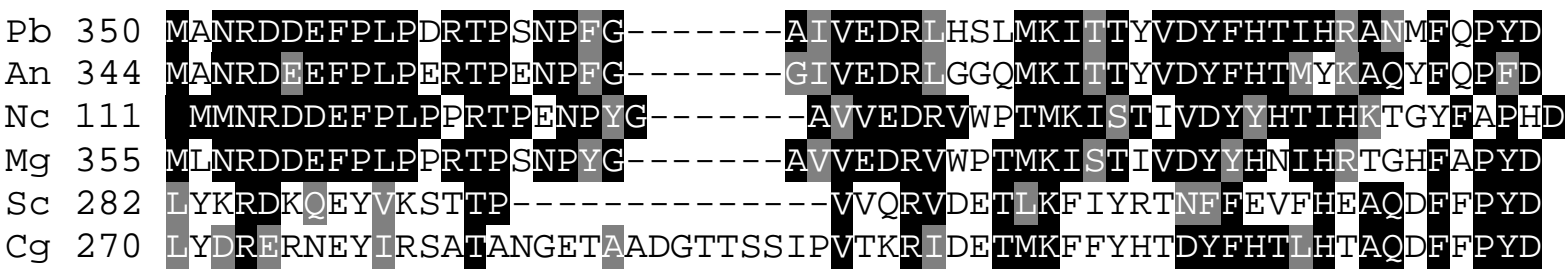

$\mathrm{Pb} 403$ PYFDCFMLFHPGLGHPSSSHEWE-ETLPYLLETKVPILCTGYSEWDMKRDLDWVMEKCGG An 397 PYLDCIVLFHPGLGHPASSHEWE-ETLPLLLETKVPIITTGYTQWDMERDI NWVREKCAG NC 164 PYFDCFVLFHPGLGHPASSHEWE-ETLPMLLETKAPIIATGYTQADMERDVEWVNKKAKG

FIGURA 31: Alinhamento da Mss51p de P. brasiliensis (Pb) com as proteínas homólogas (continua). 

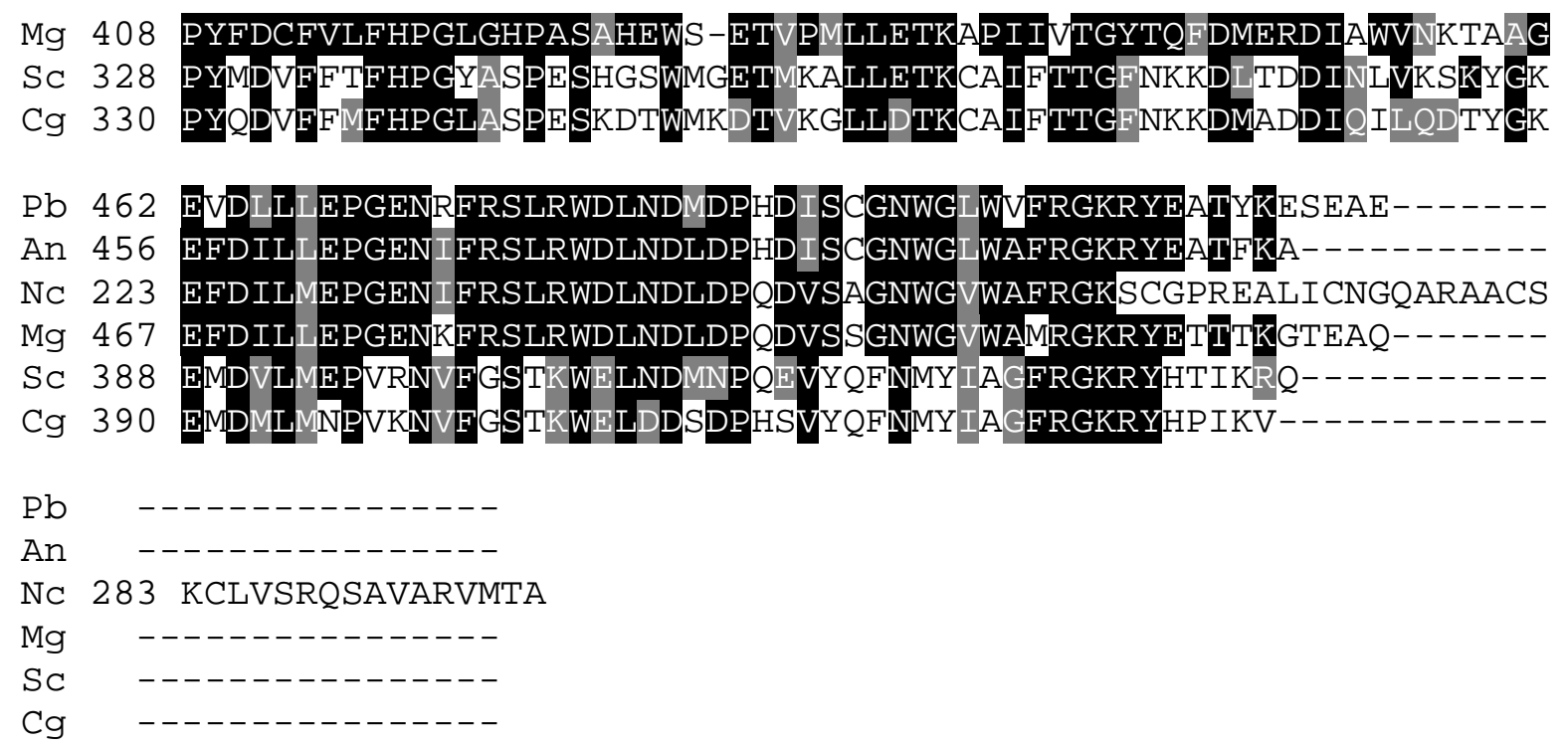

FIGURA 31: Alinhamento da Mss51p de $P$. brasiliensis (Pb) com as proteínas homólogas (continuação). de Aspergillus nidulans (Na), Neurospora crassa (Nc), Magnaporthe grisea (Mg) Candida glabrata (Cg), e Saccharomyces cerevisiae (Sc). Resíduos de aminoácidos idênticos são pintados em preto e resíduos com características semelhantes estão em cinza.

No banco de dados do fungo Paracoccidioides brasiliensis identificamos somente dois clones de ESTs (EST003371; EST001174) e um clone da biblioteca genômica (RST-VP1Pb50003-038F06) que apresentaram um bom nível de similaridade com a proteína Sco1p de S. cerevisiae. Os dois clones de ESTs pertencem ao consorcio de Brasília (Felipe et al., 2003). Os insertos destes dois clones foram totalmente seqüenciados resultando em um consenso de aproximadamente 0,9Kb cada. Entretanto em nenhum deles o a fase aberta de leitura (ORF) que codifica para a proteína PbSco1p está completa, faltando aproximadamente 112 resíduos na região N-terminal. As seqüências consensos destes clones foram utilizadas para a uma nova análise de comparação de seqüências contra o banco de dados de $P$. brasiliensis e nesta análise identificou-se outros dois clones da biblioteca genômica (RST) de P. brasiliensis que apresentavam alto índice de similaridade. Além dos dois clones genômico várias outras ESTs do consorcio de Brasília apresentaram similaridade de seqüências com as ESTs (EST003371; EST001174) referente á proteína Sco1p entretanto através de análise comparativa por BLASTx contra o banco de dados do NCBI verificamos que não se tratava da proteína Sco1p e sim de uma outra proteína com similaridade a família de proteína de citocromo p450. Um dos clones genômico (RST-VP1-Pb50003-038F06) foi escolhido submetido ao seqüenciamento completo utilizando-se a técnica de inserção de transposons. Obtivemos um consenso com 2115bp e por comparação de seqüências contra o banco de dados do GenBank/NCBI verificamos que embora tivéssemos obtido um pouco mais da porção 5' do gene PbSCO1, acessando inclusive o domínio completo da proteína PbSco1p este ainda não 
estava completo (Fig. 32). A comparação da seqüência consenso do clone RST-VP1Pb00003-038F06 por BLASTn contra o banco de dados do $P$. brasiliensis nos indicou que este gene é divido estando interrompido por dois íntrons sendo que o segundo está em fase com a fase aberta de leitura do gene PbSCO1p. Entretanto, a partir da análise de comparação utilizando a nova seqüência consenso obtida se pode verificar a presença de outra EST (EST008644) alinhando na região 5' do fragmento genômico e por esta EST finalmente conseguimos identificar o condon inicial do gene de PbSCO1.

A

Putative conserved domains have been detected, click on the image below for detailed results.

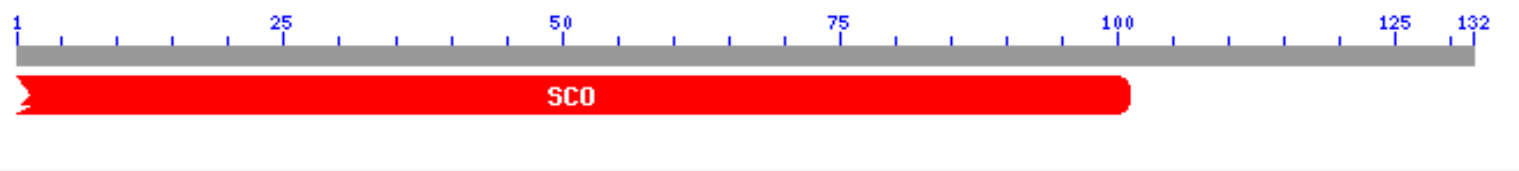

B

Putative conserved domains have been detected, click on the image below for detailed results.

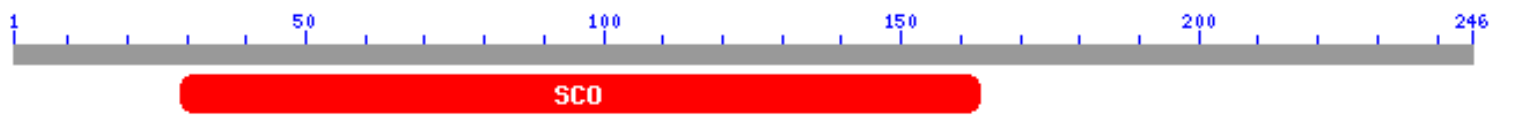

FIGURA 32: Comparação das ORFs do Clones EST003371, EST001174 e RST-VP1-Pb00003-038F06.

Alinhamento por BLASTp da fase aberta de leitura com 132 aa, identificada para o gene PbSCO1 nas ESTs EST003371; EST001174 (A), e da fase aberta de leitura com 246 aa (B) identificada na seqüência do clone genômico de $P$. brasiliensis RST-VP1-Pb00003-038F06. Embora o domínio da proteína PbSco1p esteja completo, a região 5’ do gene PbSCO1 não está completa no fragmento.

Para confirmarmos o sítio inicial de transcrição do gene PbSCO1 fizemos a clonagem do mesmo utilizando o sistema de 5'-RACE. Desenhamos um oligonucleotídeo (5'AAGTGTATGAAGAGTGGAGACTCAAAA-3') específico para a região 3’ do gene PbSCO1 baseando-se nas seqüências das ESTs e do clone genômico. A clonagem foi realizada de acordo com o protocolo do fabricante [“GeneRacer. Kit - For full-length, RNA ligase-mediated rapid amplification of 5' and 3' cDNA ends” (RLM-RACE) - Invitrogen]. Na amplificado obtivemos um cDNA com aproximadamente 1,1kb. O cDNA foi purificado e clonado em TopoTA para o seqüenciamento. Após o seqüenciamento obtivemos um consenso com 1,167bp, sendo que as trinta (30) primeiras bases (Fig. 33) correspondem ao GeneRacer 5’ Nested Primer. Neste clone, portanto, obteve-se um acréscimo de seqüência na região 5’ do gene correspondendo a 194 nucleotídeos a montante da seqüência ATC assinalado em cinza 
na figura 33. Verificamos que o códon inicial (ATG marcado em verde na figura 33) estava a 300bp a montante do códon inicial previamente identificado (ATG marcado em lilás na figura 33) na seqüência consenso do clone genômico RC2-Pb50003-038F06. Portanto, o gene PbSCO1 codifica para uma proteína com 304 resíduos de aminoácidos. As seqüências de nucleotídeos e a seqüência predita da proteína Sco1p de Paracoccidioides brasiliensis foram depositadas no banco de dados do GenBank/NCBI sob o número de acesso EF679209.

A proteína predita a partir da seqüência nucleotídica possui uma massa molecular estimada de 3.5KDa. A partir da comparação entre a seqüência genômica (RST-VP1Pb00003-038F06) e a seqüência expressa (5’RACE-PbSCO1) foi também possível confirmar a presença dos dois íntrons do gene PbSCO1 e os motivos canônicos (5' GT...AG 3') de borda intrônica (Fig. 34).

\begin{abstract}
$>\mathrm{PbSCO1}$ 5'RACE Topo GGACACTGACATGGACT GAAGGAGTAGAAAAATTGCTAGACAAAAATCTCCAATTCTGTTCCTTTTTAAATCT TTAAATTGGAAATAAGCCTGACAGCGTAATAATGACCTCGGTCTTCCTCTTCTTTTCTCGTTCGCTGGATGCG ACATGCCTCCCACCAATCCCCGTTCCTTCACAGAGCATCCACGTCCGCCTTCTCTCACTCCCCGCTTATGCCA ACCAGATCATACTATTCCAGCGGAGGAGCGTTACAAACTTACTATCCTCGGTCCGGATTACGATTGTCTCCAT TATTGATACGATCGAARCCGCATGCTACTTCATTTTCCGCCTCCTCATCCCGCCGAAAAGCCAAAACCATTCA GCAATTAAAAGCTCGCGCCGCAACGGGCCCATTCTCATGGAAAGCTGCAGTCTTATTTGTCGCAACGGGCGTG ACGATGATATTTTACTTTCGTTATGAGAAAGAGAGGCTTAATCGTAAGAGGATTGCTGAGATGAGCAAAGGTG TGGGCAGGCCGAAAGTTGGCGGACCATTCGTCCTCAAGGATTTGGATGGAAATGAATTCACGGACGAACAACT GAAGGGGAAATACAGCTTTATTTATTTCGGCTTCACTCATTGCCCGGATATTTGCCCAGATGAACTCGACAAA ATGGCCGAGATAATCGATCTTGTAAAATCTAGATCGAGCAACAAATCTGTTCTCCGGCCCATCTTCATTACCT GCGACCCAGCCCGTGACAGCCCCGAAGTGCTGCGCAAATACCTAGCAGAATTCCACAAGGGTATTATAGGCCT GACGGGCACGTACGAGCAGGTGAAGCATGTGTGCAAACAATATCGCGTCTATTTCAGCACGCCGGAGAACGTG AAGCCTGGAGAGGATTATCTTGTGGACCACAGCATTTATTTCTACCTAATGGATCCGGATGGAGATTTCATTG AATGTATCGGACGCCAAGACACTGCAGAAACCGCAGCCAACACCATTCTTGCTCATATAAAGGATTGGAAGAG GGAAGGGAAACCACTTAACACTAAAGAGGAGTAMTGTCTGGGAGAGTAAAACACAAGACCTTTCTTTTTGAGT CTCCACTCTTCATACACTTA_AGGGCGAATTCTGCAGATATCCATCACACTGGCGGCCGCTCGAGCATGCATA
\end{abstract}

FIGURA 33: Análise da seqüência consenso do clone 5’RACE-PbSCO1.

indicando a região codificadora do gene PbSCO1 de P. brasiliensis. Em amarelo temos a seqüência do GeneRacer 5' Nested Primer. A seqüência ATC indica o início da seqüência do clone RST-VP1-Pb00003-038F06 e a seqüência ATG em lilás o códon inicial predito inicialmente no clone genômico. 


\begin{abstract}
> RST-VP1-Pb0003-038F06_PbSCO1
GGGGCaT CATACTATTCCAGCGGAGGÄGCGT TACAAACTTACTATCCTCGGTCCGGATTACGATT GTCTCCATTATTGATA CGATCGAAACCGCATGCTACT TCATT TTCCGCCTCCTCATCCCGCCGAAAAGCCAAAACCATTCAGCAAT TAAAAGCTCGC GCCGCAACGGGCCCATT CTCA TGGAAAGCTGCAGTCTTATT TGTCGCAACGGGTGI GACGATGAT ATTTT ACTTT CGTTAT GAGAAAGAGAGGCTTAA TCGT AAGAGGATTGCTGAGATGAGCAAAGGTGTGGGCAGGCCGAAAGT TGGCGGACCATTCGTC CTCAAGGATTTGGATGGAAAT GAATT CACGGACGAACAACT GAAGGGGAAATACAGCTTTGTGGGTGCTCCATTT CCATCT CTATTTT TATAT TGCTT CCAT TCCAA TTGCCCTTGGAGGAGGATAT GTTAATTGAA CACCI GTTGACACT CCTACGTCCI I GAAGATT TATTT CGGCT TCACTCATT GCCCG GATAT TTGCCCAGAT GAACT CGACAAAATGGCCGAGATAATCGATCTTGT AAAATCT AGATCGAGCAACAAATCTGTTCTCCGGCCCATCT TCATT ACCTGCGACCCAGCCCGTGACAGCCCCGAAGTGCT GCGCAAATACCT AGCAGAATT CCACAAGGGT ATTAT AGGCCTGACGGGCACGTACGAGCAGGTGAAGCAT GTGTGCAAACA ATATCGCGTCTATTTCA GCACGCCGGAGAACGTGAAGCCTGGAGAGGATTATCTTGTGGACCACAGCATTTATTTCTACCT AATGGGTATGICGTGTGTTCT ATCAT TACCTCCCAGGTTATATATCTGGGATTTTTATCCCTGGT CTCCT TACCCTGGTCT CCTTACCCTGGT CACCT GGGAATATA GAACT AACCT CCGCT TCTCT GTAGA TCCGGATGGA GATT TCATT GAATGTATCGG ACGCCAA GACACTGCAGAAACCGCAGCCAACACCAT TCTTGCTCAT ATAAAGGATT GGAAGAGGGAAGGGAAACCACTTAA CACTAAA GAGGA GTAAT GICT GGGAGAGTAAAACACAAGACCTTTCTTTTT GAGTCTCCACTCTT CATACACTTCGTTTTG ACGGCAATTCAT CTATT TTGT GCCCGAAACGTGGGATTCTCGGGGT TGAGAGCCCCCGCGT TGTGATGCAATATCATTGTC GCACTCT GTCTATATTACTTGATTAT GGAGT TGGTT GGAAT TTTTGGAGTATATGT AAGAT TTACTCCTATGTTGTATTAT AATCTACACACGCACTCTCTACAGTAATTCT TTCTGCAGCT TCAAACATTAGTATGAGACATTAAAAATGACTTATGATAC CACTATT CCTGAGACTATTGCTGGGAATTGAATTGGATGICGAATT TGACATCTTGGAGTGACCT AATTTATTAT TTCAT T AAACCAACAATA TCGTA TTTAATCGT TGTCGGAAAT AATCCCCGGGATATT TTTTCAACAT CATCACATGAACCATCCTGT TGGTTTGAATGAGCTTCGTACCCTGCCAGAACACCCAACAATGCCAGTCCGACCTGCGGAGGAAA.AACACTTTTT CTCGCG CTAAATT AAAAAT ATTCATCACAAGAAT TAACCAAGCTTGCA TAAACGGCTCAAAGAAAGAT ATTAACTAGAACAT TAAAT A AAAATTCCCGTCGTCAAACCGAGTAT AGCACCCACACCAAT CCCCA.AAGCCGTCCGCCCGAAATT CTTCT TCTTCCTCCCC AACTCCCGCTCATTCGT CTCA GGTTT CAAGC GATGGAAATCCACCCTCAGGGCCCT CATTCTCTCCTCTAGCAACTTGAT T TTCTCCT GCAGCTGTGT CTTGGTCCCCCGCA GCGCGCGGCCATACT CGGAATCCTT CTGCCGCAGTGCCT CGTCGAACTCC TGCCCCAACGCCACGAGTTCGCCGGCGTATCGTTGCTTCTCCATCT CCATATCCGCATATAGTTCTCGGCCTGCAGCCGT G TTGCTCA GCTGT TGGTT GTGT AACAC CATTT CTCGT TGGAT GTCGA GGACT ATGGGCTGTCGTTT GTGCA GAAGGGCTTTC ACGATCCTT
\end{abstract}

FIGURA 34: Seqüência consenso da RST-VP1-Pb00003-038F06 do gene PbSCO1 de P. brasiliensis. indicando a região codificadora (parcial) e a seqüência dos introns, bem como os motivos canônicos de borda intrônica (5’ GT...AG 3’). O segundo íntron está em fase de leitura com a região codificadora.

Para a realização do teste de complementação heteróloga do gene PbSCO1 de Paracoccidioides brasiliensis no mutante nulo de $S$. cerevisiae foi necessário síntese um par de oligonucleotídeos (senso 5'-AAATCGGAAATAGAGCTCACAGACGTAA e anti-senso 5'-AAGTGTATGAAGAGTCGACACTCAAAA) que inseriram os sítios de reconhecimento das enzimas de restrição SacI e SalI nas extremidades 5' e 3' respectivamente da região codificadora. A amplificação da região codificadora do gene PbSCO1 foi realizada a partir de cDNAs Poli(T) nas seguintes condições: Uma desnaturação inicial de $94{ }^{\circ} \mathrm{C}$ por 4 minutos, seguido por 35 ciclos de: desnaturação a $94{ }^{\circ} \mathrm{C}$ por 1 minuto; anelamento dos primers a $56{ }^{\circ} \mathrm{C}$ por 30 segundos e extensão a $72{ }^{\circ} \mathrm{C}$ por 1 minuto. Após os 35 ciclos seguiu-se mais 10 minutos a $72{ }^{\circ} \mathrm{C}$ e finalmente resfriamento a $4{ }^{\circ} \mathrm{C}$. O produto amplificado foi submetido à dupla digestão com as enzimas SacI e SalI seguindo as condições do fabricante (Fermentas Life Sciences). O produto da digestão foi purificado e ligado no vetor pMGL3 previamente digerido nas mesmas condições e tendo suas extremidades 5' desfoforiladas com a enzima CIAP - "Calf Intestine Alkaline Phosfatase”. A ligação seguiu o protocolo do fabricante (Promega). A mistura de ligação foi transformada na bactéria E.coli DH10B competente preparada pelo método de Cloreto de Cálcio. 
O recombinante $p M G L 3 / P b S C O 1$ selecionado por análise de seqüenciamento foi utilizado no ensaio de complementação funcional mutante nulo aW3034sco1::URA de $S$. cerevisiae. Não obtivemos a complementação funcional da deficiência respiratória deste mutante de $S$. cerevisiae com o gene PbSCO1 indicando que a proteína Sco1p de $P$. brasiliensis não é capaz de substituir a função da proteína homologa ScSco1p.

O gene SCO1 foi identificado e caracterizado por (Schulze e Rodel, 1989) que relataram que, mutações neste gene induzia uma deficiência respiratória relacionada especificamente a COX desde que, não foi constatado nenhuma alteração em outras enzimas da cadeia respiratória ou da ATPase. Verificou-se em trabalhos posteriores que o gene SCO1 era necessário para estabilizar as proteínas mitocondriais Cox1p e Cox2p (Kru mMeck e Rodel,1990), proteínas estas que constituem o corpo catalítico da citocromo oxidase. Glerum et al., 1996, baseando-se na observação de que a super expressão da Sco1p combinada com um ligeiro aumento na concentração de cobre no meio de cultura é capaz de suprimir a deficiência da proteína Cox17p, a qual já se sabia ser uma proteína ligante de cobre, sugeriram que a proteína Sco1p teria uma função no transporte de cobre para o complexo da citocromo c oxidase (Glerum et al., 1996b; Beers et al., 1997). Estudos posteriores propuseram que a proteína Sco1p possui um domínio ligante de cobre $(\mathrm{CxxxC})$ e que estaria envolvida no transporte de cobre para as subunidades I e II do complexo da citocromo c oxidase (Rentzsch et al.,1999). Em S. cerevisiae a proteína Sco1p possui um seguimento transmembrana contendo cerca de dezessete (17) resíduos de aminoácidos (Buchwald et al., 1991), já o motivo ligante de cobre (CxxxC) da proteína Scop1 foi identificado na porção C-terminal sendo uma região hidrofílica que se encontra projetada para a região intermembranar mitocondrial (Rentzsch et al.,1999; Beers et al., 1997). A proteína PbSco1p identificada em Paracoccidioides brasiliensis também apresenta uma região de hélice transmembrana predita com cerca de vinte e dois resíduos de aminoácidos (Fig. 35) e o motivo (CxxxC) ligante de cobre (Fig. 36). 

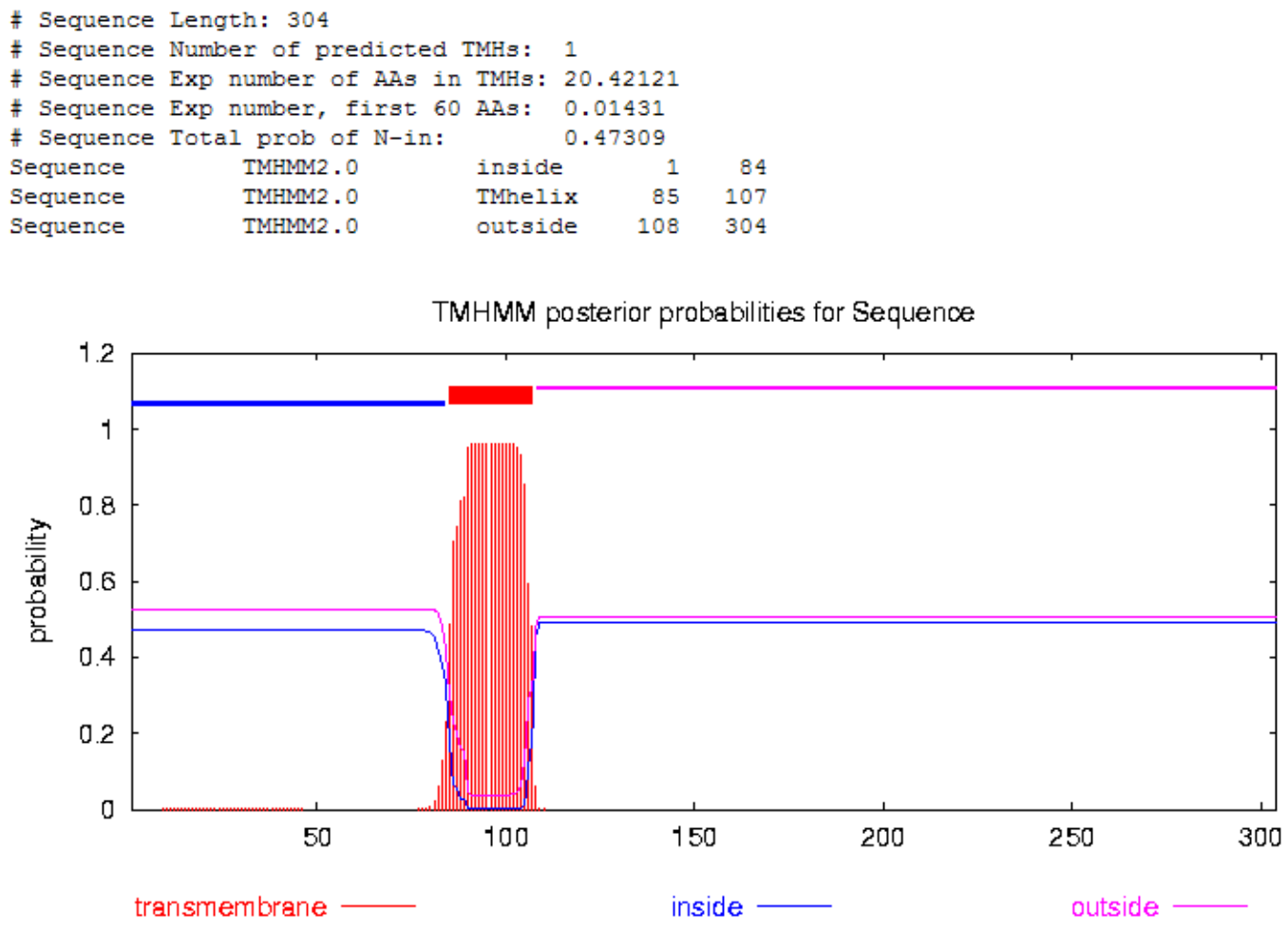

FIGURA 35: Análise de resíduos característicos de hélices transmembrana na PbSco1p. quanto a presença de regiões características de hélice transmembrana obtida a partir da ferramenta TMHMM Server v. 2.0 disponível na página http://www.cbs.dtu.dk/services/TMHMM/. 


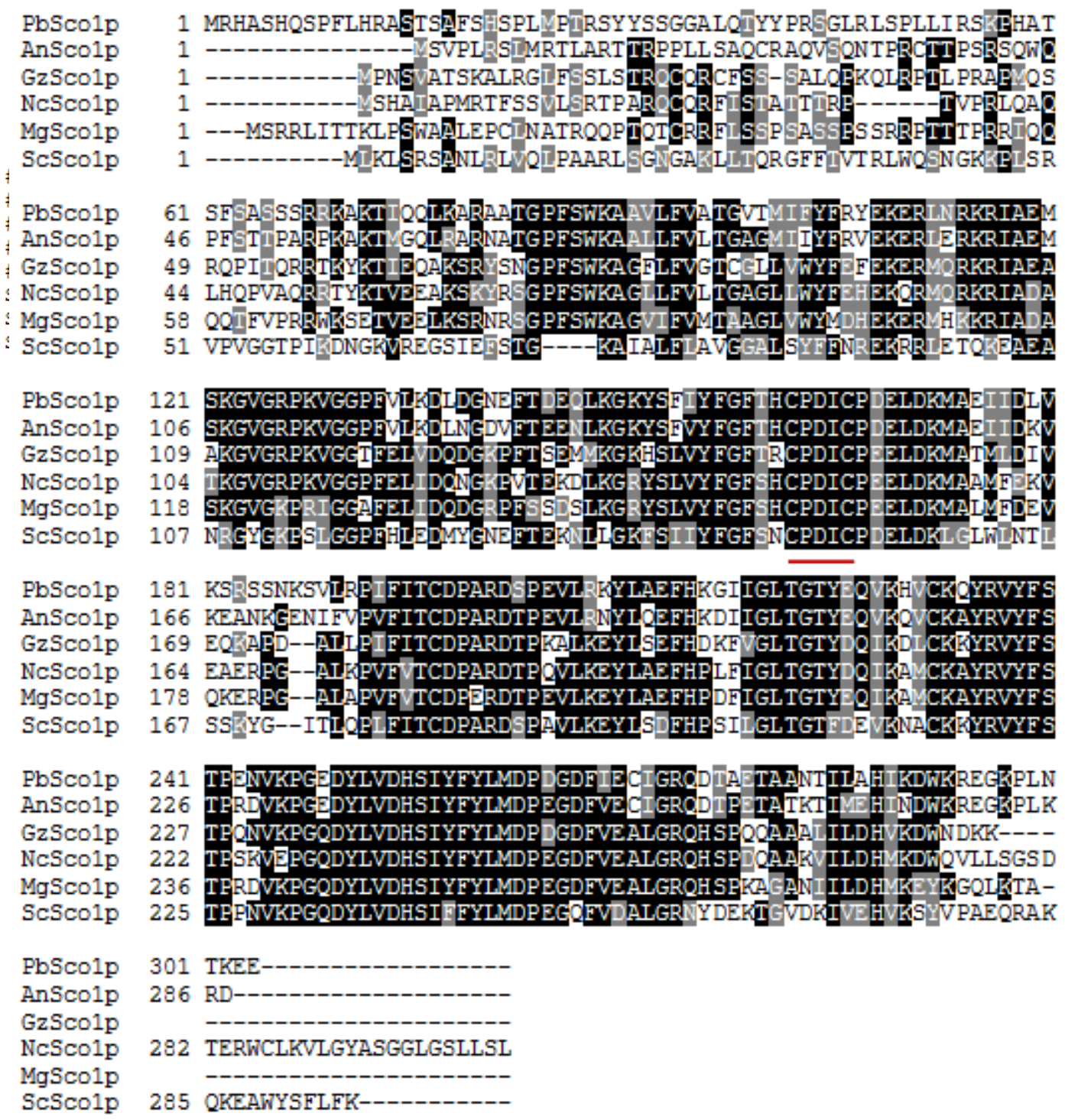

FIGURA 36: Alinhamento da Sco1p de P. brasiliensis $(\mathrm{Pb})$ com as proteínas homólogas.

de Aspergillus nidulans (An), Gibberella zeae (Gz), Neurospora crassa (Nc), Magnaporthe grisea (Mg) e Saccharomyces cerevisiae (Sc). Resíduos de aminoácidos idênticos são pintados em preto e resíduos com características semelhantes estão em cinza. A barra indica o domínio CXXC ligante de cobre.

O alinhamento (Fig. 36) entre proteínas Sco1p de vários organismos indicam que esta proteína é bem conservada entre as várias espécies entretanto, a região N-terminal, representante do peptídeo sinal de endereçamento para a mitocôndria apresenta-se bem diversificada entre as espécies e embora a proteína de $P$. brasiliensis apresente o motivo ligante de cobre CXXC esta diferença pode ser um dos motivos da incapacidade de complementação funcional da proteína Sco1 de P. brasiliensis no mutante de S. cerevisiae.

Em S. cerevisiae o gene SCO1 compartilha homologia com o gene SCO2 cujo produto também está localizado na mitocôndria, mas não é requerido para a respiração e o mutante nulo apresenta níveis normais do complexo da citocromo c oxidase (Glerum et al., 1996a). 
Super expressão de SCO1 pode restaurar a deficiência do mutante nulo de cox17, já o seu homólogo SCO2 embora também possa restaurar a capacidade respiratória do mutante nulo, isto só ocorre parcialmente e na condição específica em que o meio é suplementado com cobre exógeno (Glerum et al., 1996a). A super expressão de COX17 não restaura a deficiência do mutante sco1 sugerindo que a proteína Sco1p atua em uma etapa posterior a proteína Cox17p, tanto antes como durante a inserção do cobre (Glerum et al., 1996a). A homologia da seqüência primária dos genes SCO1 e SCO2 e suas atividades na supressão da mutação de cox17 sugeriram que eles possam ter uma função redundante entretanto ensaios de complementação funcional do mutante nulo sco1 com seu homólogo SCO2 demonstraram que o gene SCO2 não é capaz de restaurar a deficiência do mutante nulo sco1, indicando que estas duas proteínas não são intercambiáveis e, portanto, não são funcionalmente equivalentes. (Entretanto, o gene SCO2 é capaz de restaurar parcialmente, algum tipo de mutações pontual no gene sco1 Glerum et al., 1996a). A supressão alelo específica de sco1 pelo homólogo SCO2 poderia indicar uma interação física da Sco1p e Sco2p necessária para a função, entretanto esta suposição é contradita pela observação de que o mutante nulo sco2 não apresenta deficiência respiratória (Glerum et al., 1996a).

Diferentemente do que ocorre em Saccharomyces cerevisiae em humanos, mutações tanto em SCO1 quanto em SCO2 causam deficiências fenotípicas bem severas. Mutações nestes genes produzem uma deficiência tecido-específica da citocromo c oxidase associada a fenótipos clínicos distintos embora ambos sejam expressos igualmente em todos os tecidos (Leary et al., 2004). Mutações no gene SCO2 em humanos são predominantemente associadas com o aparecimento de cardiomiopatia hipertrófica infantil (Jaksch et al., 2000) enquanto que mutações em SCO1, identificadas até o momento somente em uma família, resultam em uma desordem neonatal progressiva afetando predominantemente o fígado (Valnot et al., 2000).

Estudos mais recentes (Leary et al., 2007) relatam que as chaperonas mitocondriais Sco1 e Sco2 que são essenciais na montagem do complexo da citocromo c oxidase, também são responsáveis pela manutenção da homeostase de cobre das células e desta forma estes autores demonstram uma nova função da mitocôndria. Segundo estes pesquisadores mutações em qualquer um destes dois genes (SCO1 e SCO2) resultam em uma deficiência celular de cobre que é tanto tecido quanto alelo específico. Este fenótipo pode ser dissociado da deficiência na montagem do complexo da citocromo c oxidase e a deficiência de cobre é suprimida pela super expressão de SCO2, porém não de SCO1 (Leary et al., 2007). Estes pesquisadores concluem que o fenótipo de deficiência de cobre não reflete em uma mudança na alta afinidade de captação de cobre, porém sim no aumento proporcional do efluxo de 
cobre. Portanto, ainda serão necessários mais estudos sobre a função destes genes (SCO1 e SCO2), pois esta ainda não foi completamente elucidada.

\subsubsection{PbOXA1}

Com a sequência da proteína Oxa1 de S. cerevisiae fez-se a primeira busca nos bancos de dados de $P$. brasiliensis utilizando-se a ferramenta tBLASTn. Identificou-se um clone de EST (EST001011) com boa similaridade. EST esta do consorcio central Brasil (Felipe et al., 2003) que foi clonada em fago lambda. Neste caso não conseguimos excisar o plasmídeo (pBluescript) embora, tenhamos realizado este mesmo procedimento com sucesso em outras amostras. Na segunda busca utilizou-se a sequência da EST001011 para uma nova análise busca por comparação de sequências (BLASTn) nos bancos de dados de $P$. brasilensis. Foi possível identificar mais dois clones sendo uma nova EST (EST-VP1-Pb30001-205H03) e um clone de sequência genômica RST-VP1-Pb50003-024E10, ambos pertencentes ao consórcio paulista (Goldman et al., 2003).

O clone referente à EST-VP1-Pb30001-205H03 foi então submetido ao seqüenciamento através da técnica de inserção de transposons. O cDNA completo consiste de aproximadamente 2047bp. Utilizando a ferramenta ORFfinder do NCBI localizou-se a fase aberta de leitura compreendendo a proteína $P b O x a 1 p$ que é constituída de 474 resíduos com predição de 51,7KDa. As seqüências nucleotídica e peptídica referente ao gene OXA1 de $P$. brasiliensis estão depositadas no GenBank/NCBI sob o número de acesso DQ836715.

Uma análise de comparação de seqüência por BLASTp indica que esta ORF identificada possui o domínio conservado YidC (Fig. 37), uma proteína de membrana de E. coli que facilita a inserção de um conjunto de proteínas de membrana e é homologa da $O x a 1 p$ mitocondrial e Alb3 de cloroplastos (Samuelson et.al., 2000; Celebi et al., 2006; du Plessis et al., 2006). 


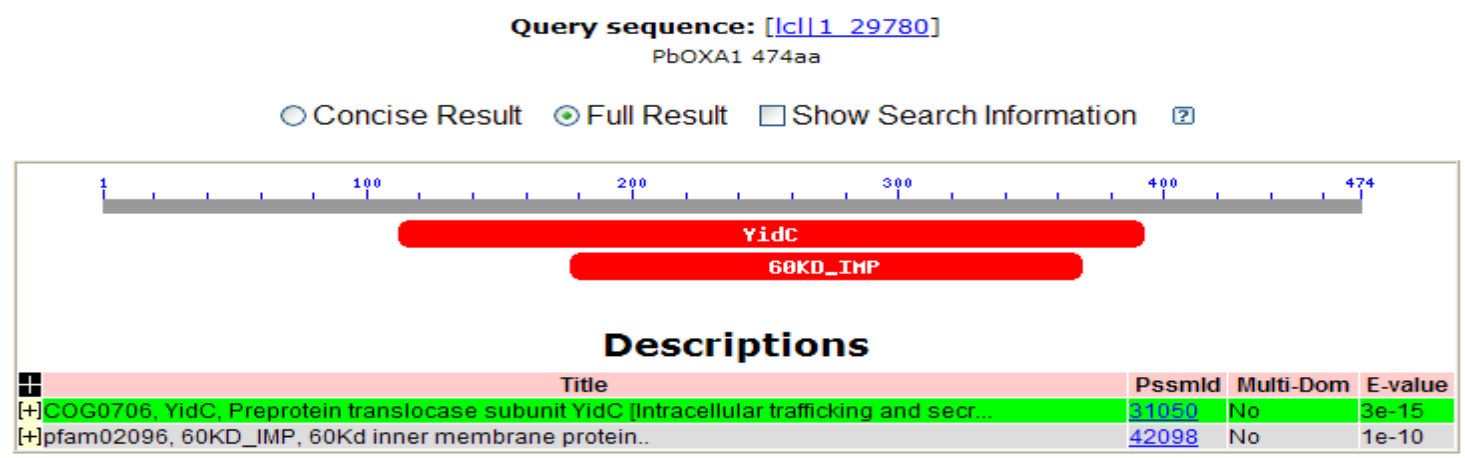

FIGURA 37: Alinhamento por BLASTp ORF dda proteína PbOxa1p.

identificada na EST-VP1-Pb30001-205H03. A figura mostra o domínio conservado YidC indicando uma função de insertase para esta proteína.

Após a confirmação da identidade deste clone, a seqüência completa do inserto de cDNA foi submetida à análise física de restrição utilizando a ferramenta NEBcutter www.neb.com e através desta análise verificou-se a possibilidade de excisão da ORF direcionada para clonagem em vetor de expressão de $S$. cerevisiae utilizando-se as enzimas SmaI e XbaI. Após a dupla digestão enzimática, o fragmento SmaI/PbOXA1/XbaI foi isolado em gel preparativo 1\% agarose extraído por eletroeluição e purificado por precipitação com etanol.

O fragmento purificado foi ligado no vetor pMGL3 previamente linearizado com as mesmas enzimas e tendo as extremidades 5' desfosforiladas com a enzima CIP -Calf Intestine Phosphatase. A mistura de ligação foi inserida em E. coli DH10B por transformação em células competentes pelo método químico de $\mathrm{CaCl} 2$ e dez (10) transformantes foram coletados aleatoriamente. Os pDNAs dos transformantes selecionados foram extraídos e a seleção do plasmídeo recombinante pMGL3/PbOXA1 foi realizada através de seqüenciamento.

O recombinante selecionado ( $p M G L 3 / P b O X A 1)$ foi então inserido por transformação pelo método de LiOAc no mutante nulo aW3034oxal::HIS de $S$. cerevisiae. Os transformantes foram selecionados em meio mínimo (WO) devidamente suplementado e a capacidade da proteína $P b O x a 1 p$ de restaurar a deficiência respiratória deste mutante de $S$. cerevisiae foi analisada quanto à capacidade de crescimento em meio com fontes de carbono não fermentáveis etanol e glicerol. Após 48 horas de crescimento em estufa a $30{ }^{\circ} \mathrm{C}$ verificou-se o crescimento das linhagens recombinantes com o gene PbOXA1 de $P$. brasiliensis (aW3034oxal::HIS/pMGL3/PbOXA1) em níveis comparáveis ao da linhagem selvagem (Fig. 38) indicando que este gene de $P$. brasiliensis é homólogo ao gene OXA1 da levedura S. cerevisiae. 
YPD

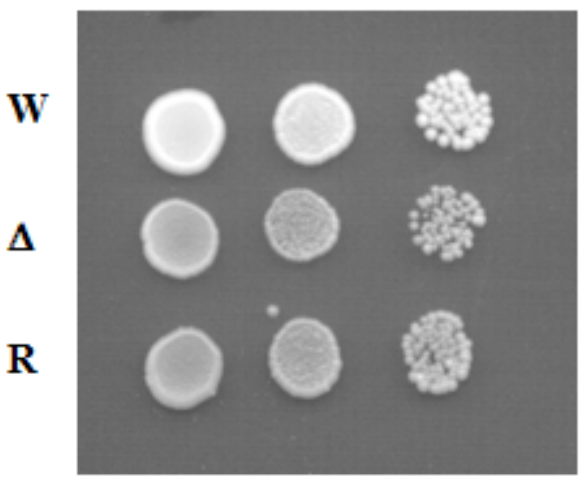

EG

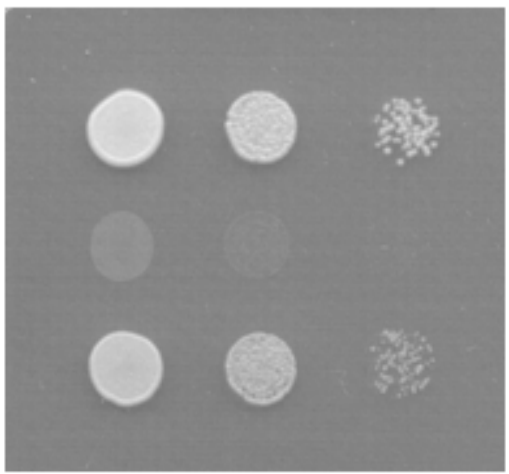

FIGURA 38- Complementação funcional da proteína PbOxa1.

Crescimento das linhagens selvagem aW303 (W), do mutante deficiente respiratório de $S$.

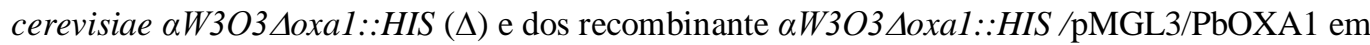
meio rico YPD e em meio contendo etanol/glicerol como fonte de carbono (EG) após 48 horas de incubação a $30{ }^{\circ} \mathrm{C}$.

Para confirmarmos este resultado fizemos a "Transformação reversa”. Como esperado o resultado foi confirmado, ou seja, novamente houve a restauração da capacidade respiratória do mutante aW3034oxa1::HIS de S. cerevisiae.

O alinhamento entre a proteína PbOxa1 com suas homólogas em outros fungos (Fig. 39) mostra que embora o alinhamento não apresente blocos muito conservados ele se estende mais ou menos homogêneo em toda a extensão das proteínas, inclusive há um bom alinhamento na região N-terminal onde geralmente encontra-se a seqüência sinal de endereçamento mitocondrial. Pode-se notar que aproximadamente na posição do resíduo 107 da proteína de $P$. brasiliensis existe uma inserção de 15 resíduos que é especifica deste organismo. Esta inserção não causa um efeito divergente suficiente para impossibilitar a complementação desta proteína (PbOxa1p) de P. brasiliensis em mutantes de $S$. cerevisiae. 
PbOXA1 1 MSGSHFARLPILLIMLGKTGVRPWAAVSLSGVTRRTMLAAPPSTRHLSTVTTRKFFQSKL AnOXA1 1 …

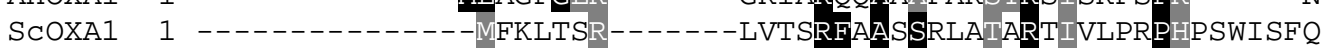
NCOXA1 1 SpOXA1 1 . . . . . . . . . MFSVIGRG . . . . . . . IKFSSKSHYSVSCFLIATQGAKIR - . .

Pb0XA1 61 RNPIHNATGLLRTSSWTNSVAVQFAGLANPRFNSTTTNPSSTSAPSSLNSIDTVNPPLSSG AnOXA1 34 SKVLG-...-GNTSWR-APVPFIALPTARFNSTSTTAPTEVTPETQ - ............ SCOXA1 39 AKRFN - .....-STGPNANDVSEIQTQLPSIDELTSSAPSLSASTSD - . . NCOXA1 47 PLGTTATAAASHQLLSSLRQVRYASTGPDAAVAADAAAAAAAAPSSSP . . . . . .

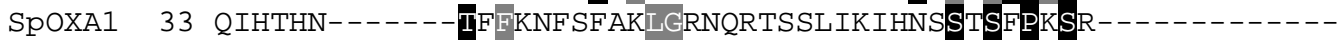

Pb0XA1 121 VESIDSLSVADPVSIDISQIPETLGYLKAIGLDYGWG-PSRLIETILESLHIHGGLPWVG AnOXA1 74 -...-PSSELDVSNIDLTQIPERIGYLKDLGLDYGWG-PSAIVEFMIEHIHIYSGLPWVG SCOXA1 79 -.....-LIANTTQTVGELSSHIGYLNSIGLAQTWYWPSDIIQHVLEAVHVYSGLPWWG NCOXA1 95 -VDAVAATPVELTGSDLLNLPEQIGFLKTLGLDYGWG-VTS MMQWLTEHVYVYSGLPWWA Sp0XA1 73 -.......

PbOXA1 180 ATITTAVLLRVAMLKFATDASDTSAKVASVK - - HLTQPIQQEVKRCYREN - DTIGMQRAL AnOXA1 128 SIIATGIFFRLAMAPLFWRAGDTSARLANAQ - -PILAPIKEKMLNAARSG - NQVEAQKWR SCOXA1 131 TIAATTILIRCLMFPLYVKSSDTVARNSHIK - -PELDALNNKLMSTT - - - - DLQQGQLVA NCOXA1 153 TLAAVAAIVRVAIFKPSLGASQESQKKMQDLNKNPKYAAIMAKVKEASFDTTKQNDLVKKYR SPOXA1 118 SIAACAVAMRIAVFPIMLK MMKTSAKLAIIN- -PKVAEHMSVLSKAKAEGNSEL MMQATT

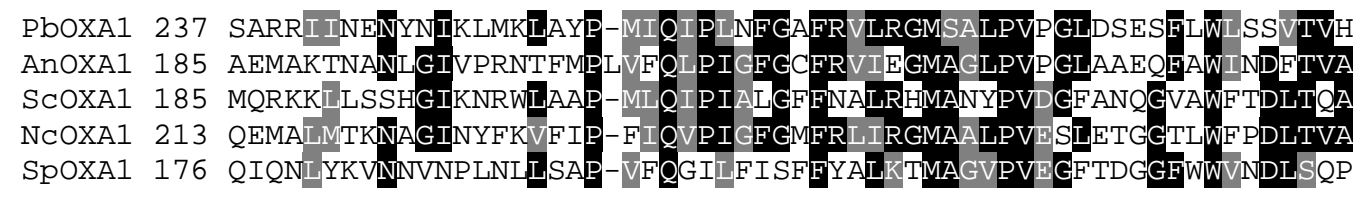

Pb0XA1 296 DPLFILPVSTGLLMHYTFFLGGEVSASTDQTAMAAKPLLLYGLPVLSTVCTLFLPGILQI AnOXA1 245 DPTYILPILCCTVLHLSIRKGGETGSSMSGDMATIRKG MMYGIPAFSFFFVAFFPAALA SCOXA1 244 DPYLGLQVITAAVFISFTRLGGETG- - -AQQFSSPMKRLFTILPIISIPATMNLSSAVVL NCOXA1 272 DPYFALPIASACLFVASMRKPIPYMAP - - QQAR MMKSMGLVLVPVSIFATAWLPAALQW SP0XA1 235 DPLHIFPVANGLLMLLNIELGSETGSN -KVAMSPSMKKFFRFLCLASPLFTMNFPMAIFM

PbOXA1 356 FFASTISVLATLQSYSFHSYSFRRALGMAPFPKR - - - PDQSSNTPTGPKVRIIEAPRDN AnOXA1 305 YFLTTGFLGLLQAYAFANATFRKATGMTVIEKLNPVQPSGSNPAEPNRALRLITEALERE SCOXA1 301 YFAFNGAFSVLQTMILRNKWVRSKLKITEVAKP - - - RTPIAGASPTENMGIFQSLKHN NCOXA1 329 YFLVSAIGQYFQASIFHLPAFRRWVGLPELVPGGMRGPSPFAKAAAPSSTIQYVAPRTMD SPOXA1 294 YWFPSNVFSVFQGAFLRSSTIRHKLGLPEVPSAMP - VPNAQNESFVKSFTDIVHGVQVKG

PbOXA1 411 - - - -STASSHIEQVPKVS- -FIDRFISSSCQNS - - - IKDTRKKMEDIVGQNQKVEKFADG AnOXA1 365 NAKLNEAKKIAAEQPKIS- -FIDRAINNIKESKEKLTKETTQKMQELSGQGPKKNADGSL SCOXA1 356 .............. IQKARDQAERRQ - LMQDNEKKLQESFKEKRQNSKIKIV NCOXA1 389 TTATPVDSGSILGDIKDSSNFVKEKLEDWKKKNDNTNIHSRAKEYEERRALEEHEAYLAR

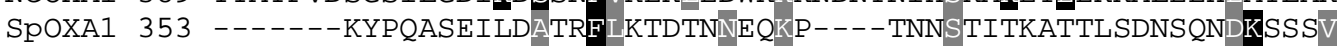

PbOXA1 461 TPKVRMTKKQLQGC AnOXA1 423 AEPPRLSEKDRKLAEDYERRRKEEEDWKREERNHARREAYRQAMERERQRAKAALNKSEV ScOXA1 393 HKSNFINNKK- NCOXA1 449 LELKKQKQKGRKNH- $\ldots$ SPOXA1 402 TKPTEKKD -

Pb0XA1 - AnOXA1 $483 \mathrm{KQ}$

SCOXA1 - -

Nc0XA1 - -

SP0XA1 - -

FIGURA 39: Alinhamento da proteína Oxa1p de P. brasiliensis (Pb) com as proteínas homólogas. de Aspergillus nidulans (An), Saccharomyces cerevisiae (Sc), Neurospora crassa (Nc) e Schizosaccharomyces pombe (Sp). Resíduos de aminoácidos idênticos são pintados em preto e resíduos com características semelhantes estão em cinza. 
O clone genômico RST-VP1-Pb50003-024E10 também foi inteiramente seqüenciado através da técnica de inserção de transposons obtendo-se um consenso com 1762bp. A comparação entre a seqüência genômica e a seqüência expressa do clone de ESTs indicou a presença de dois (02) íntrons no gene PbOXA1.

Considerando que com o gene OXA1 de originário do clone de EST P. brasiliensis restabeleceu a função respiratória do mutante nulo de $S$. cerevisiae, foi também constuído o recombinante deste gene originário de segmento genômico com dois introns. Com esta constução não foi possível restabelecer a função respiratória deste mesmo mutante de $S$. cerevisiae. Provavelmente porque a linhagem mutante de $S$. cerevisiae não processou os introns encontrados no PbOXA1 genômico. Portanto, os estudos indicam a inexistência de complementação heteróloga direta (a partir de seqüência genomica) entre os fungos $S$. cerevisiae e P. brasiliensis.

A proteína Oxa1p é conservada desde os procariotos até os eucariotos superiores (Bauer et al., 1994; Bonnefoy et al., 1994a). Em S. cerevisiae, a proteína Oxa1p é codificada pelo genoma nuclear, traduzida no citoplasma é importada para a matriz mitocondrial em uma forma precursora, onde é processada e submetida vários eventos de exportações através da membrana interna da mitocôndria (Herrmann et al., 1997). De acordo com estes autores, a proteína Oxa1p contém cinco domínios transmembrana (TM) intercalados por regiões hidrofílicas. Entretanto, a análise por domínios de hélices transmembrana através da ferramenta TMH MM Server v. 2.0 indica que embora haja cinco regiões com aminoácidos hidrofóbicos, característicos de hélice transmembrana, somente uma hélice é predita (Fig. 40A). A homóloga de $P$. brasiliensis também possui regiões características, mas não apresenta nenhuma hélice predita, segundo esta ferramenta (Fig. 40B).

Mutações no gene OXA1 levam ao bloqueio da biosíntese da citocromo c oxidase e oligomicina sensitiva ATPase (Altamura et al., 1996) devido principalmente a uma deficiência nos estágios pos-traducionais (Bonnefoy et al., 1994). Além do produto gênico do OXA1 ser requerido para a biosíntese da citocromo c oxidase, desordens neste gene também ocasionam um defeito secundário pleiotrópico em estágios iniciais da expressão de proteínas mitocondriais (Bonnefoy et al., 1994). O gene OXA1 da levedura S. cerevisiae está localizado no cromossomo VIII e é adjacente ao gene PET122, o qual controla o inicio da tradução do mRNA de COX3 (Bonnefoy et al., 1994; Ohmen et al., 1988). O produto gênico de OXA1 é requerido para a exportação da subunidade II da citocromo c oxidase, sendo a principal responsável pela geração da topologia N-out e C-out, através da qual as duas extremidades da proteína Cox2p ficam expostas no espaço intermembranar (He et al., 1997; Hell et al., 1997). 
O gene HsOXA1 foi o primeiro gene envolvido na biogênese da citocromo c oxidase a ser caracterizado em humano, através da complementação funcional em mutantes de $S$. cerevisiae (Bonnefoy et al., 1994b). A complementação funcional em mutantes oxa1 de $S$. cerevisiae também foi obtida com sucesso para o gene AtOXA1 de Arabidopsis thaliana (Hamel et al., 1997). A função conservada da proteína Oxa1p em bactérias gram-positiva e negativa, bem como em eucariotos superiores sugere que esta proteína possui uma função crucial em todos os seres vivos (Bonnefoy et al., 1994). 
A \# ScOXA1 Length: 402

\# ScOXA1 Number of predicted TMHs: 1

\# ScOXA1 Exp number of AAs in TMHs: 71.05070999999999999999999999999

\# ScoXA1 Exp number, first 60 AAs: 0.00962

\# ScoXAl Total prob of $\mathrm{N}-\mathrm{in}$ : 0.28821

SCOXA1 TMHMM2.0 outside 12281

$\begin{array}{llll}\text { ScOXA1 TMHMM2.0 } & \text { TMhelix } & 282 & 304\end{array}$

SCOXA1 TMHMM2.0 inside $305 \quad 402$

TMHMM posterior probabilities for ScOXA1

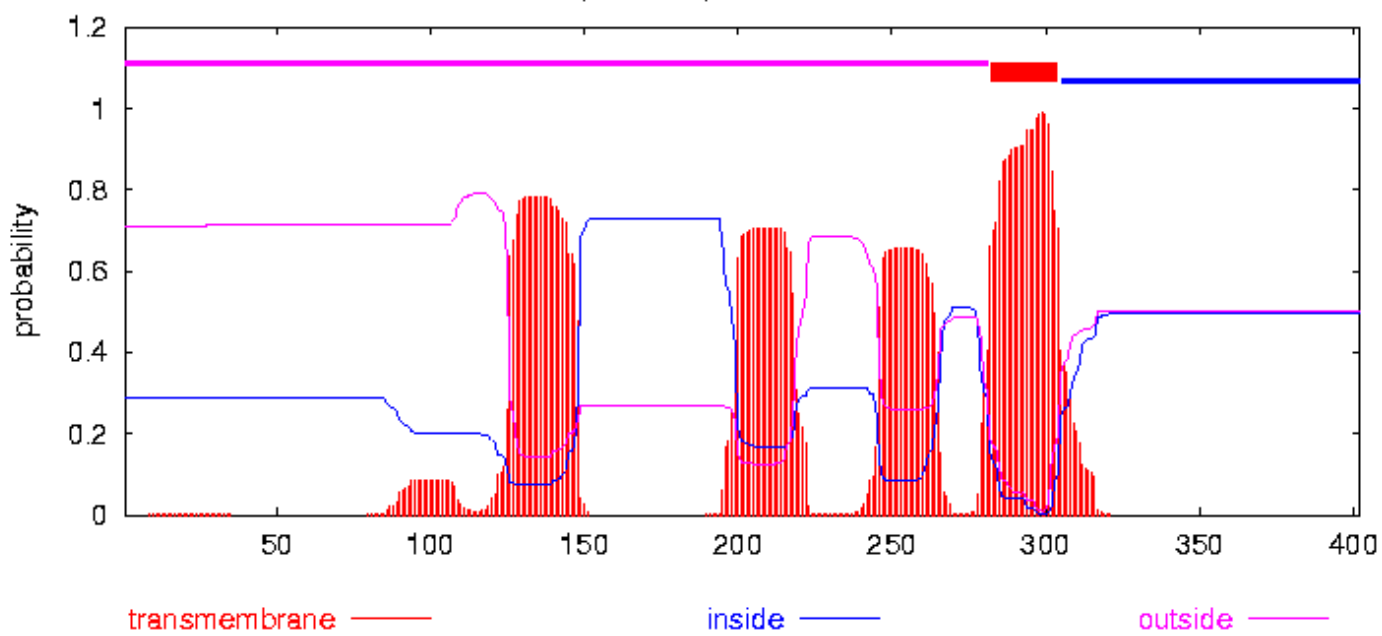

B

\# PboXal Length: 474

\# PbOXA1 Number of predicted TMHs: 0

\# PbOXA1 Exp number of AAs in TMHs: 50.51715

\# PboXA1 Exp number, first 60 AAs: 1.20897

\# PboXA1 Total prob of N-in: 0.06024

PbOXA1 TMHMM2.0 outside 1474

TMHMM posterior probabilities for PbOXA1

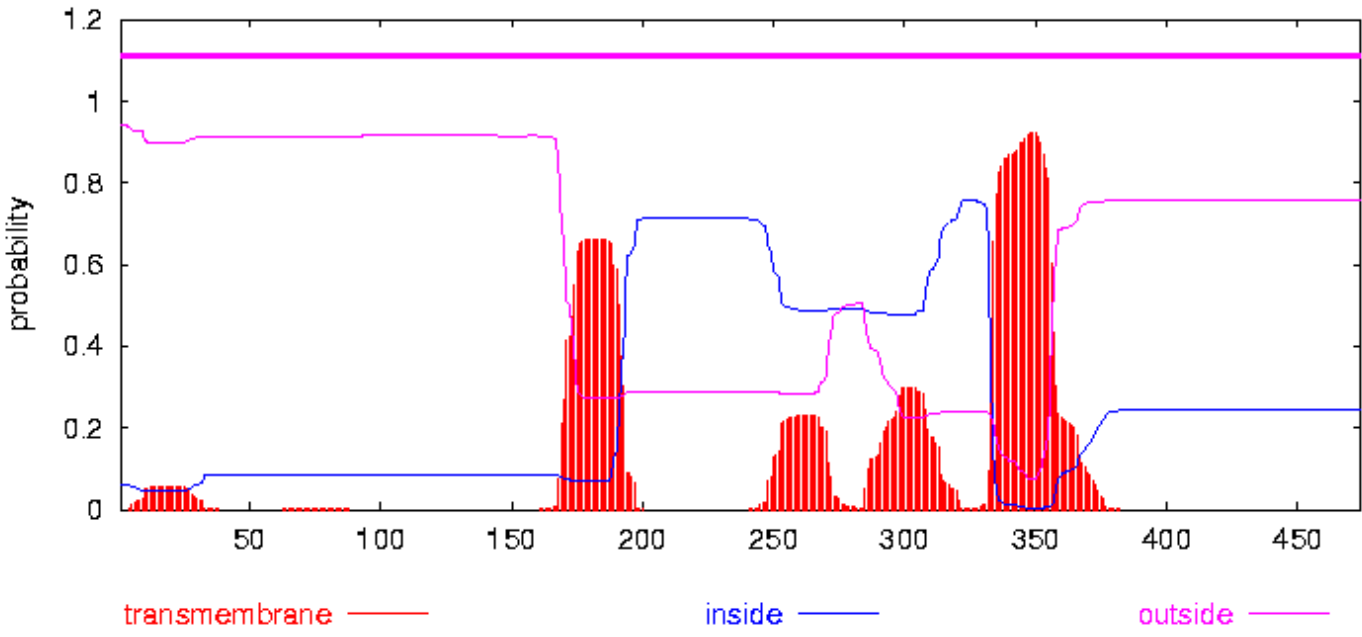

FIGURA 40A: Análise de resíduos característicos de hélices transmembrana na proteína Oxa1p de $S$. cerevisiae. obtida a partir da ferramenta TMHMM Server v. 2.0 disponível na página http://www.cbs.dtu.dk/services/TMHMM/. 40B: Análise semelhante com a proteína Oxa1p de $P$. brasiliensis. 
Deleção do gene SpoIIIJ, homologo de OXA1 em B. subtilis, bloqueia a esporulação em um estágio intermediário (Errington et al., 1992) entretanto, o fato de que o SpoIIIJ é um gene expresso somente durante o crescimento vegetativo e tem um homólogo em bactéria não esporogênica, sugere que o defeito de esporulação possa não ser um efeito primário da deleção, principalmente considerando que leveduras deficiente respiratória também não esporulam (Bonnefoy et al., 1994). Estudos posteriores têm sugerido que existe uma via biosintética conservada evolucionalmente para a inserção de proteínas na membrana interna da mitocôndria, cloroplastos e bactérias e acredita-se que as proteínas Oxa1/Alb3/YidC atuem como insertases que possuem uma função importante na biogênese de proteínas de membrana relacionadas à produção de energia (Ott et al., 2005).

\subsection{Resistência à Peróxido de Oxigênio (H2O2)}

Além da função na atividade respiratória da célula, a proteína Cox11p foi recentemente relacionada à outra função que é a de conferir resistência a peróxido de hidrogênio (Banting e Glerum, 2006). Sabe-se também que mutantes de S. cerevisiae com deficiência na proteína cox11p apresentam sensibilidade a vários produtos químicos como, por exemplo, psoralenos fotoativados e N-nitrosodietilamine (NDEA) (Brendel e Henriques, 2001; Pungartnik et al., 2002). Entretanto, a função da proteína Cox11p na resistência a peróxido de hidrogênio é independente de sua função na citrocomo c oxidase (Khalimonchuk et al., 2007). Segundo estes autores o mutante nulo de cox11 possui deficiência respiratória e sensibilidade a peróxido de hidrogênio, porém, quando mutações pontuais que afetam seus sítios ligantes de cobre são inseridas no gene cox11 estes mutantes têm seu crescimento em fontes de carbono não fermentável impedido entretanto estas mutações não causam sensibilidade a peróxido de hidrogênio. O fenótipo sensível a peróxido de hidrogênio do mutante nulo é provavelmente devido ao acúmulo de um intermediário transiente formado pelo grupo heme a3-Cox1p e que confere sensibilidade ao oxidante (H2O2). Esta forma intermediária (heme a3-Cox1p) não se forma nas linhagens selvagens ou nos mutantes pontuais da Cox11p, mesmo que o complexo da citocromo c oxidase não seja completamente montado (Khalimonchuk et al., 2007).

Diante das evidências de que esta função é independente da função em COX decidimos verificar se a proteína PbCox11p de Paracoccidioides brasiliensis poderia ser funcional na complementação heteróloga desta segunda função. Para este ensaio a linhagem recombinante 
aW303ACOX11::HIS3/pMGL3-PbCOX11 e as linhagens controle (a selvagem aW303 e a linhagem com mutação nula de cox11 (aW303 peróxido de hidrogênio em várias concentrações e em períodos de 1 e 2 horas de exposição.

Os resultados apresentados na Fig. 41A indicam que a proteína Cox11 de P. brasiliensis restabelece esta função (sensibilidade a peróxido) em mutantes de cox11 de $S$. cerevisiae. A diferença de crescimento entre a linhagem mutante e a linhagem recombinante ficou mais evidenciada após cinco dias a $4{ }^{\circ} \mathrm{C}$. 

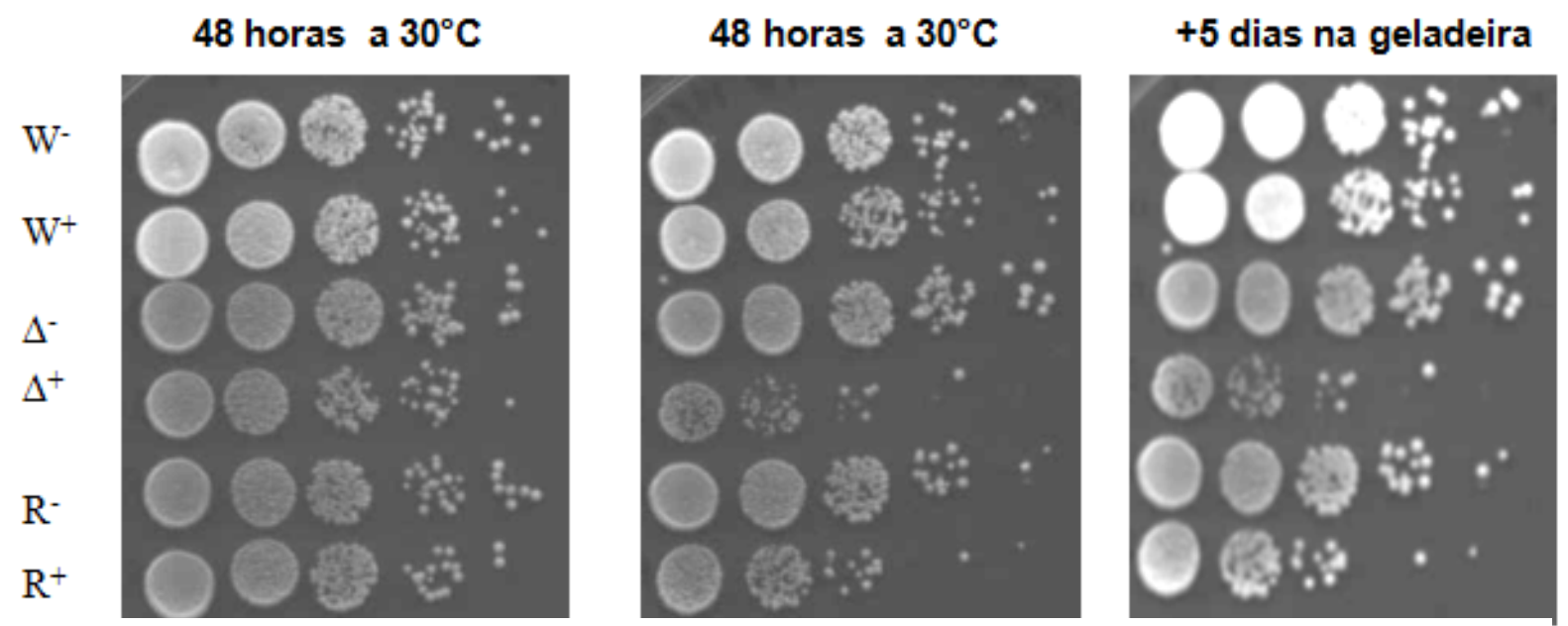

FIGURA 41A: Teste à sensibilidade por peróxido de hidrogênio.

Estão indicados na figura as concentrações usadas de $\mathrm{H}_{2} \mathrm{O}_{2}$; a temperatura de incubação e o tempo de exposição ao peróxido. As linhagens utilizadas foram: (-) ausência, (+) presença de H2O2; $(\mathbf{W}-$ ou $\mathbf{W}+)=W 303-1 A ;(\Delta+$ e $\Delta$ - $)=a W 303 \Delta C O X 11: \because H I S 3$ e $(\mathbf{R}+$ e $\mathbf{R}-)=$ aW303ACOX11::HIS3/pMGL3-PbCOX11.
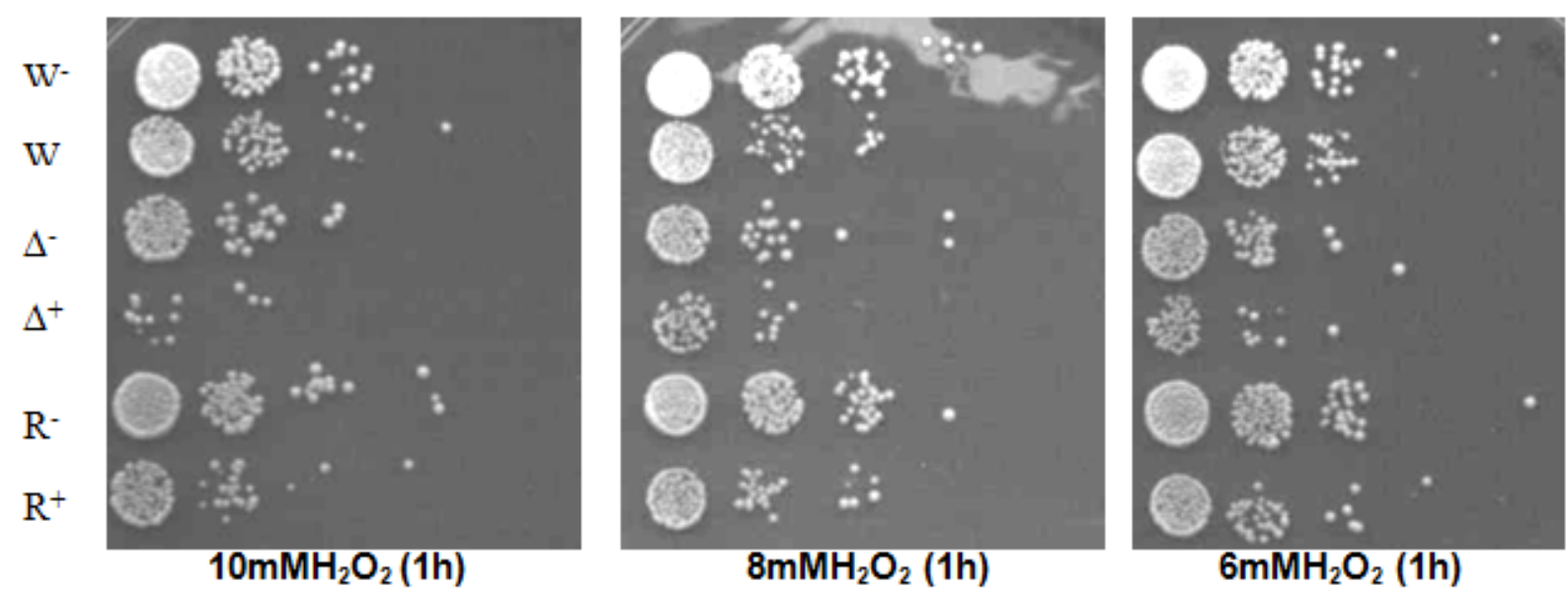

FIGURA 41B: Sensibilidade por peróxido de hidrogênio.

Estão indicadas as concentrações de $\mathrm{H}_{2} \mathrm{O}_{2}$ utilizadas numa exposição de uma hora. As linhagens e os símbolos são os mesmos da Fig. 41- A

Para melhorar a diferenciação de crescimento entre as linhagens mutantes aW303ACOX11::HIS3 e recombinantes aW303ACOX11::HIS3/pMGL3-PbCOX11 da linhagem selvagem estas linhagens foram submetidas a um novo ensaio em condições um pouco mais drásticas do estresse de peróxido de hidrogênio. Neste ensaio as concentrações foram de 6 mM, 8 mM e 10M H2O2 e o período de exposição foi de apenas 1 hora. 
Nas novas condições estabelecidas tornou-se evidente que a $P b \operatorname{Cox} 11 p$ restabelece a função quanto a sensibilidade à peróxido (Fig. 41B) em mutante nulo para cox11 de $S$. cerevisiae. Este resultado é semelhante ao obtido por Khalimonchuk et al., 2007 com a proteína humana (HsSco1p) em mutante de S. cerevisiae. Sabe-se que as proteínas Cox11 e Sco1 foram relatadas como pertencentes à classe de proteínas envolvidas nas duas funções (Banting e Glerum 2006). Assim como a proteína PbCox11p a proteína HsSco1p também não complementa a capacidade respiratória de mutante de S. cerevisiae.

O recombinante de $S$. cerevisiae com a proteína PbSco1p também foi submetido a este ensaio e os resultados foram comparáveis aos obtidos com a PbCox11p (Fig. 42).

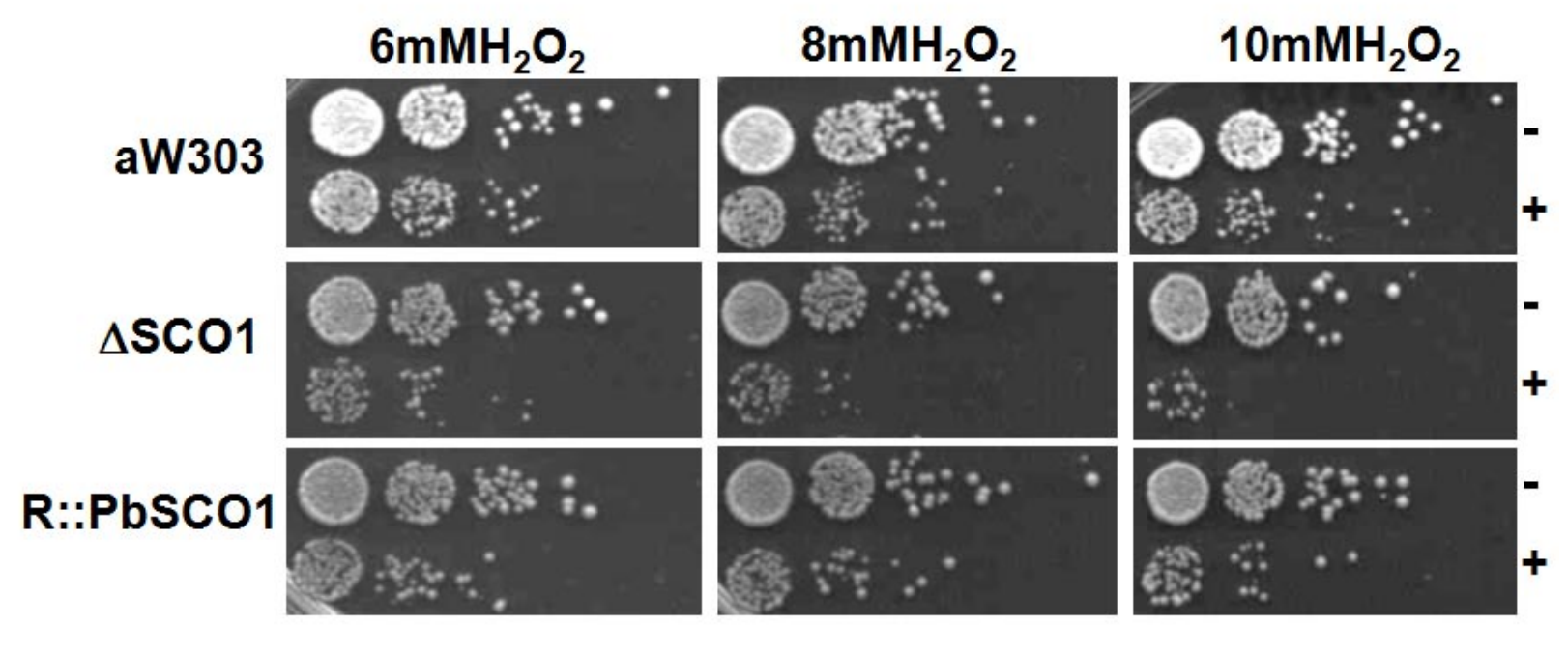

FIGURA 42: Hipersensibilidade do mutante $a W 303 \Delta s c o 1$ ao peróxido de hidrogênio.

A cultura líquida em fase exponencial foi exposta a 6 , 8 e $10 \mathrm{mM} \mathrm{H}_{2} \mathrm{O}_{2}(+)$ por $1 \mathrm{~h}$, diluídas em série (1:10) e inoculadas em meio YPD, juntamente com as linhagens controle não tratadas (-), e incubadas por $36 \mathrm{~h}$ à $48 \mathrm{~h}$ para se determinar o potencial de formação de colônias. A linhagem parental aW303 não apresenta hipersensibilidade a $\mathrm{H}_{2} \mathrm{O}_{2}$. A resistência ao peróxido foi restabelecida com a expressão do gene homólogo PbSCO1 de P. brasiliensis.

Outros genes de $S$. cerevisiae estão relacionados ao fornecimento de cobre para o complexo da citocromo c oxidase mitocondrial. O gene COX17 (Glerum et al., 1996), COX19 (Nóbrega et al., 2002) e o COX23 (Barros et al., 2004). Mutantes de cox17 foram reportados como sendo não sensíveis ao peróxido de hidrogênio (Banting e Glerum, 2006). Com o objetivo de verificar se este mutante (cox17) apresenta alguma sensibilidade ao peróxido em diferentes concentrações e testar a sensibilidade ao peróxido dos outros dois mutantes (cox19 e cox23) de $S$. cerevisiae relacionados ao metabolismo de cobre estas linhagens mutantes de S. cerevisiae foram submetidas ao estresse de peróxido de hidrogênio nas condições citadas 
acima. Os resultados indicam que os mutantes cox19 e cox23 também são sensíveis ao peróxido e que o mutante cox17 também apresenta certa sensibilidade em altas concentrações (8 mM e $10 \mathrm{mM}$ ) desse oxidante (Fig. 43).

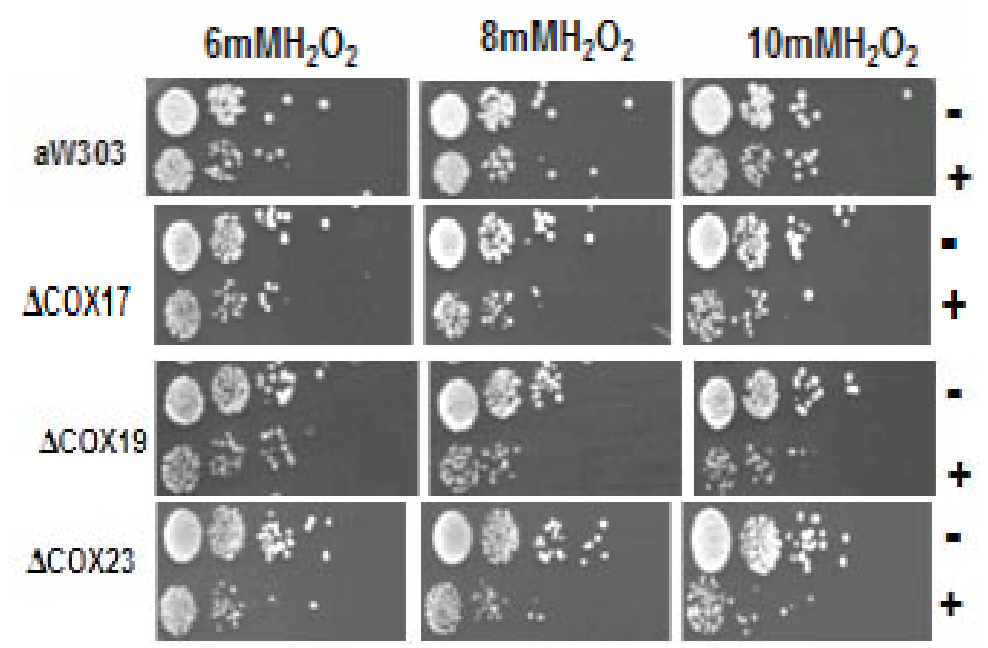

FIGURA 43: Sensibilidade dos mutantes $a W 303 \Delta \operatorname{cox} 17$ e $a W 303 \Delta \operatorname{cox} 19$ e $B Y 4741 \Delta \operatorname{cox} 23$ a $\mathrm{H}_{2} \mathrm{O}_{2}$.

$\mathrm{O}$ ensaio foi realizado de acordo com o descrito na figura 02. Os mutantes apresentam diferentes níveis de sensibilidade ao peróxido de hidrogênio.

Com o objetivo de verificar se os homólogos de $P$. brasiliensis são capazes de substituir esta função nos respectivos mutantes de $S$. cerevisiae, as linhagens mutantes de $S$. cerevisiae e as linhagens recombinantes com os genes PbCOX17, PbCOX19 e PbCOX23 de P. brasiliensis foram submetidas ao estresse de peróxido de hidrogênio. A resistência ao peróxido foi restabelecida nas linhagens recombinantes com os genes $P b C O X 17$ e PbCOX19 de P.brasiliensis (Fig. 44). Já no caso da linhagem recombinante com o gene PbCOX23 a sensibilidade ao peróxido parece ser ainda mais exacerbada. Este resultado necessita ainda ser melhor investigado.

No total temos, portanto, cinco complementações heteróloga positivas na função respiratória e quatro na função de resistência ao peróxido de hidrogênio. 


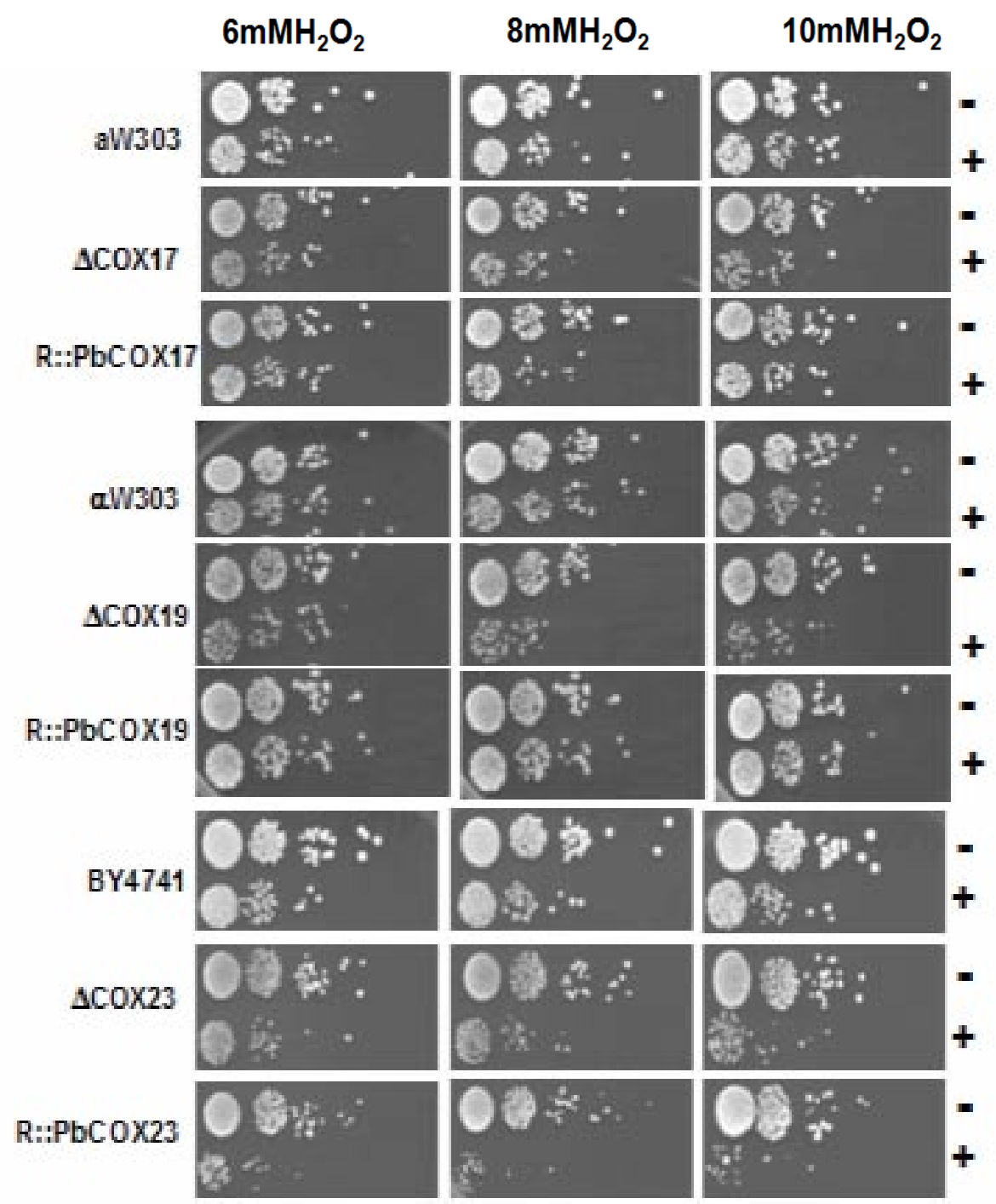

FIGURA 44: A resistência ao peróxido de hidrogênio é restabelecida pelos homólogos de $P$. brasiliensis. nos mutantes aW303 $\Delta$ cox17 e aW303 $\Delta$ cox19. O ensaio foi realizado de acordo com o descrito na figura 02. Os mutantes apresentam diferentes níveis de sensibilidade ao $\mathrm{H}_{2} \mathrm{O}_{2}$. Os homólogos PbCOX17 e PbCOX19 são capazes de restaurar a resistência ao peróxido nos respectivos mutantes de $S$. cerevisiae. O mutante BY4741 $\Delta$ cox23 também é sensível, porém a expressão dos homólogos $\mathrm{PbCOX} 23$ de $\mathrm{P}$. brasiliensis parece aumentar esta sensibilidade. 


\subsection{Estrutura Genômica}

Através de análise de comparação de seqüências dos genes identificados (Tabela 4) com aproximadamente 12.000 seqüências genômica aleatórias P. brasiliensis (RSTs “Random Sequence Tags”) geradas a partir de uma biblioteca construída em vetor pUC18 (Nóbrega, M e colaboradores), foi possível acessarmos a estrutura genômica de seis genes (PbCOX8, PbCOX11, PbMSS51, PbPET191, PbOXA1 e PbSCO1).

Para o estudo da estrutura genômica dos genes PbCOX4, PbCOX5A, PbCOX6, PbCOX9, PbCOX12, PbCOX13, PbCOX15, PbCOX16, PbCOX17, PbCOX19, PbCOX23, PbPET100 e PbPET112 a estratégia foi a identificação de clones na biblioteca genômica de $P$. brasiliensis construída em vetor do tipo fosmídeo contendo insertos de aproximadamente 40kb (Nóbrega, M e colaboradores). A biblioteca total consiste de 29 placas com 96 clones cada, ou seja, 2784 clones. A identificação dos clones foi realizada pelo método de hibridização em super-membranas contendo 96 amostras, com cada amostra contendo 12 clones da biblioteca genômica. As sondas foram preparadas a partir da amplificação dos insertos referentes a cada um dos genes. Na maioria dos casos utilizamos os oligonucleotídeos das extremidades dos plasmídeos para a amplificação dos insertos. Os fragmentos foram purificados (Fig. 45) e utilizados para marcação das sondas seguindo o protocolo do fabricante do kit de marcação (Gene Images Random Prime Labelling Module - Amersham Bioscienses). As reações de hibridizações nas membranas seguiram as instruções do fabricante do kit de detecção (Gene Images CDP-Star detection module - Amersham Bioscienses). Como cada amostra das membranas foi montada a partir de uma coleção de 12 clones, a detecção se deu sempre em duas etapas. Primeiro identificamos a amostra da coleção contendo os 12 clones e em seguida identificação do clone específico de interesse. 


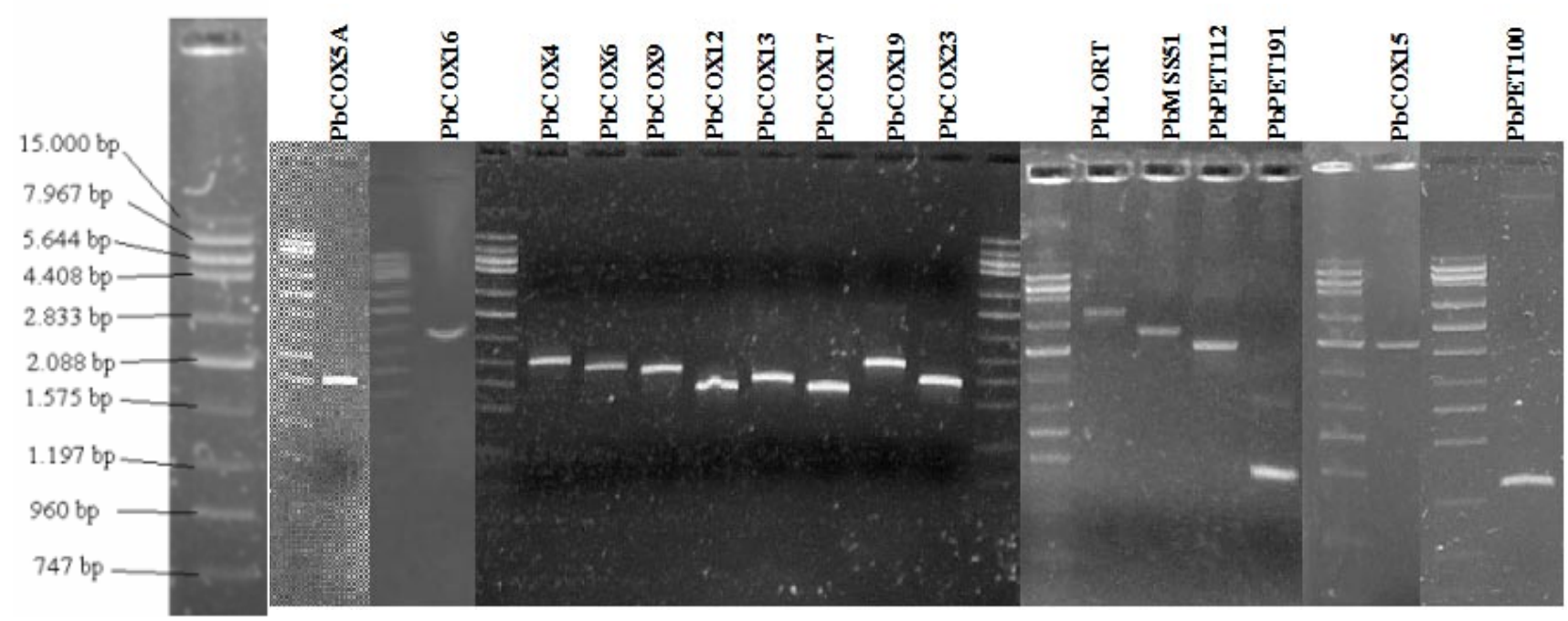

FIGURA 45: Fragmentos utilizados com sonda de hibridização.

Análise em géis $1 \%$ agarose contendo $1 \mu \mathrm{L}$ do produto da reação de PCR (eletroeluído e purificado) referentes a cada gene que foi utilizado para a marcação gerando as sondas para as reações de hibridização em membranas.

Duas abordagens foram utilizadas para identificar o clone específico de interesse: Uma delas consistiu em preparar uma nova membrana contendo os doze clones dispostos individualmente e em seguida fazer uma nova hibridização. Esta estratégia foi utilizada na identificação dos clones referentes aos genes PbCOX4, PbCOX6, PbCOX9, PbCOX12, PbCOX15, PbCOX19, PbCOX23, PbPET112, PbPET191 e PbMSS51 (Fig. 46: A-L). A outra abordagem foi amplificar os fragmentos por reação de PCR a partir dos clones individuais da coleção referente ao clone já identificado utilizando os oligonucleotídeos disponíveis. Desta forma identificou-se os clones referentes aos genes PbCOX5A, PbCOX16 e PbPET191. 


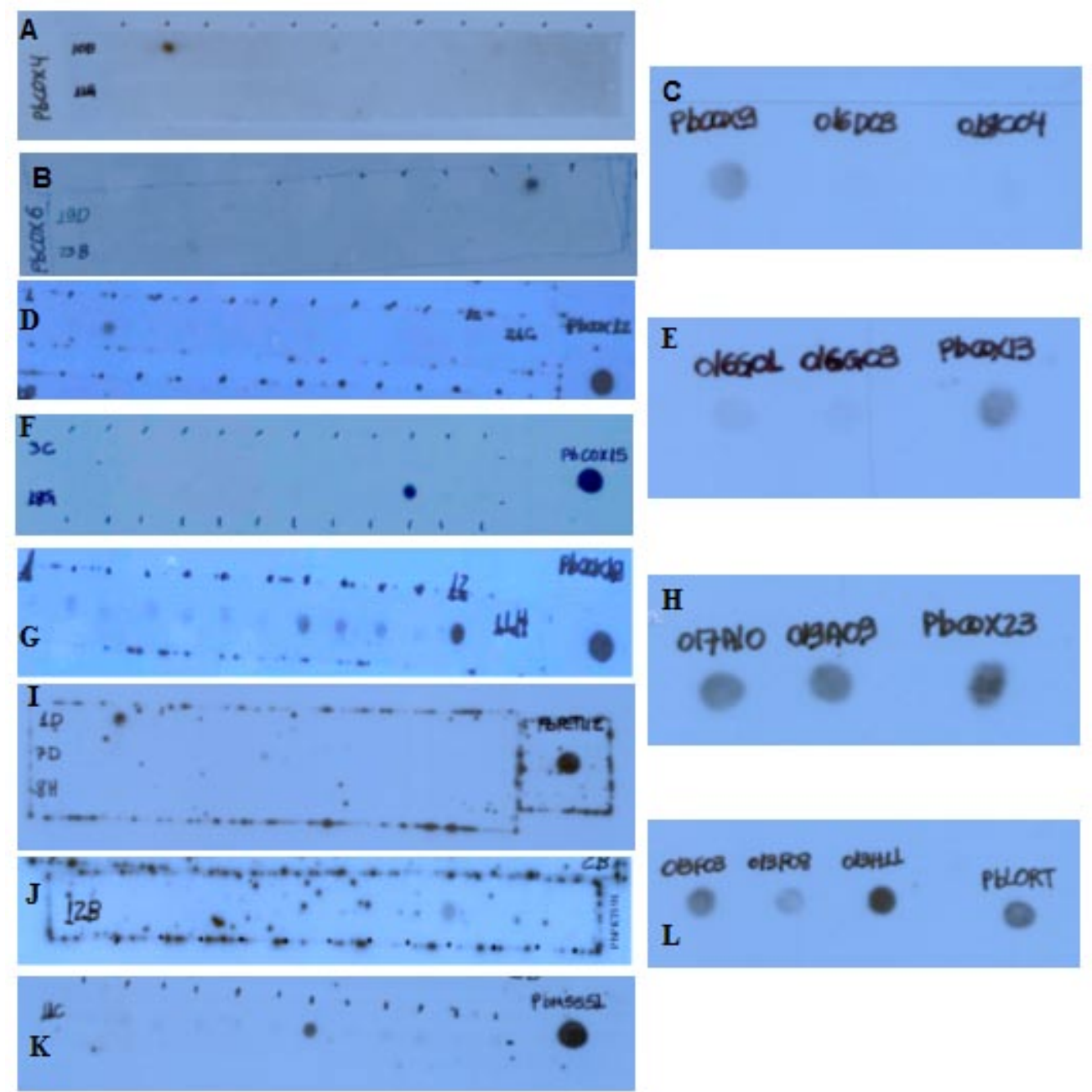

FIGURA 46: A-L: Identificação dos clones da biblioteca genômica (Fosmid) de P.brasiliensis. referente aos genes PbCOX4 (A), PbCOX6 (B), PbCOX9 (C), PbCOX12 (D), PbCOX13 (E), PbCOX15 (F), PbCOX19 (G), PbCOX23 (H), PbPET112 (I), PbPET191 (J), PbMSS51 (K) $e$ PbLORT (L) a partir de hibridização em membranas.

Após a identificação dos clones da biblioteca de fosmideos referente a cada gene de interesse cada clone seria submetido ao seqüenciamento completo entretanto, como já comentado na introdução deste trabalho, os genomas de três isolados de $P$. brasiliensis foram totalmente seqüenciados pelo FGI - Fungal Genome Initiative e se encontram disponíveis em: http://www.broad.mit.edu/annotation/genome/paracoccidioides_brasiliensis/MultiHome.html.

Diante dessa situação, o seqüenciamento dos clones identificados foi interrompido, sendo a análise da estrutura genômica dos genes de interesse realizadas através de comparação de seqüências utilizando os dados genômicos disponíveis. A análise consistiu na comparação das seqüências dos genes identificados com a seqüência genômica dos isolados 
Pb01, Pb03 e Pb18, utilizando a ferramenta de BLASTn disponível na página do FGI. Os resultados foram sumarizados na Tabela 5.

TABELA 5: Distribuição de íntrons dos genes estudados no isolados Pb01, Pb03 e Pb18 de P. brasiliensis.

\begin{tabular}{|c|c|c|c|c|c|c|}
\hline Gene & $\begin{array}{l}\text { Superconti } \\
\text { g Pb01 }\end{array}$ & $\begin{array}{l}\text { Número } \\
\text { de } \\
\text { Introns }\end{array}$ & $\begin{array}{l}\text { Superconti } \\
\text { g Pb03 }\end{array}$ & $\begin{array}{l}\text { Número } \\
\text { de } \\
\text { Introns }\end{array}$ & $\begin{array}{l}\text { Supercontig } \\
\text { Pb18 / (chr) }\end{array}$ & $\begin{array}{l}\text { Número } \\
\text { de } \\
\text { Introns }\end{array}$ \\
\hline$* \mathrm{PbCOX} 4$ & 20 & 7 & 2 & 5 & 4 / (chr 4) & 7 \\
\hline *PbCOX5A & 29 & 2 & 17 & 2 & 16 / (chr nd) & 2 \\
\hline PbCOX6 & 23 & 3 & 9 & 3 & $7 /(\operatorname{chr} 1)$ & 3 \\
\hline$* P b C O X 8$ & 26 & 2 & 20 & 2 & 15 / (chr 2) & 2 \\
\hline *PbCOX9 & 7 & 2 & 15 & 3 & $8 /(\operatorname{chr} 5)$ & 3 \\
\hline PbCOX11 & 1 & 3 & 8 & 3 & $10 /(\operatorname{chr} 5)$ & 3 \\
\hline $\mathrm{PbCOX12}$ & 17 & 4 & 8 & 4 & $10 /$ (chr 5) & 4 \\
\hline * PbCOX13 & 16 & 4 & 9 & 3 & $7 /($ chr 1) & 4 \\
\hline$P b C O X 15$ & 30 & 1 & 19 & 1 & $18 /$ (chr 4) & 1 \\
\hline PbCOX16 & 3 & 1 & 3 & 1 & $1 /(\operatorname{chr} 1)$ & 1 \\
\hline PbCOX17 & 3 & 2 & 5 & 2 & $1 /(\operatorname{chr} 1)$ & 2 \\
\hline * PbCOX19 & 6 & 3 & 4 & 3 & $2 /(\operatorname{chr} 3)$ & 3 \\
\hline * PbCOX23 & 2 & 3 & ----- & ----- & 4 / (chr 4) & 4 \\
\hline PbPET100 & 11 & 1 & ----- & ----- & $5 /(\operatorname{chr} 2)$ & 1 \\
\hline * PbPET112 & 4 & 5 & 3 & 4 & $1 /($ chr 1) & 4 \\
\hline PbPET191 & 10 & 2 & 5 & 2 & $11 /(\operatorname{chr} 1)$ & 2 \\
\hline * PbMSS51 & 32 & 2 & 2 & 2 & $4 /(\operatorname{chr} 4)$ & 2 \\
\hline * PbOXA1 & 10 & 3 & 5 & 3 & $11 /(\operatorname{chr} 1)$ & 2 \\
\hline * PbSCO1 & 19 & 2 & 3 & 2 & $1 /(\operatorname{chr} \mathbf{1})$ & 2 \\
\hline
\end{tabular}

Os dados foram obtidos na página do FGI - fungal Genome Initiative. Os genes assinalados com $(*)$ apresentam fortes evidencias de splicing alternativo e chr (cromossomo), chr nd (cromossomo não determinado). Dados atualizados em 28/10/008.

Em geral há grande diversidade entre os isolados quanto à quantidade de íntrons e às evidências de ocorrência de splicing alternativo. Para o isolado Pb18 já se encontra disponível o números do cromossomo em que localiza os genes.

O gene PbCOX4 é o exemplo mais significativo de gene que apresenta splicing alternativos. Além da diferença de número de íntrons entre os isolados, o gene estudado através do transcrito da EST001692 apresenta uma fase aberta de leitura de 197 resíduos de aminoácidos (AY603795) enquanto que a análise genômica apresenta a possibilidade de esta proteína ser constituída por 313 resíduos no isolado Pb18. A comparação entre as duas seqüências protéicas indica a permanência de íntrons na proteína predita (313 aa) por análise do genoma. 
O gene PbCOX5A também apresenta evidencias da ocorrência de splicing alternativo. Também apresenta variação no número de resíduos preditos entre os isolados e entre a proteína predita pelo transcrito da EST-VP1-Pb30001-211E08 e a proteína predita pela análise da seqüência genômica. A diferença neste caso é de somente três (03) resíduos.

O gene PbCOX6 com três íntrons, apresenta-se bem consistente entre os três isolados com 171 resíduos preditos para a proteína $P b \operatorname{Cox} 6$, o que é também coincidente com o números de resíduos preditos a partir do estudo da EST-RC2-PbNEW1-155A05.

O gene PbCOX8 foi inicialmente identificado no clone RST-VP1-Pb30003-012G11 com um fragmento genômico de aproximadamente 1971bp que está depositado no banco de dados do GenBank/NCBI sob o número de acesso EF988665. A região codificadora do gene está localizada na porção central do fragmento com cerca de 542bp a montante do códon iniciador. O gene $\mathrm{PbCOX} 8$ codifica para uma proteína com 86 resíduos de aminoácidos e está interrompido por dois (02) introns contendo os motivos canônicos (5'GT...AG3') de borda intrônica (Reinoso et al., 2005). A análise do gene $P b C O X 8$ no genoma dos três isolados de $P$. brasiliensis confirmam a presença dos dois íntrons em cada isolado entretanto mostra variações entre as proteínas preditas, tanto entre a proteína identificada no transcrito identificado por amplificação por PCR (EF681771) quanto entre os três isolados. A proteína PbCox8p predita no genoma do isolado Pb01 é composta por 77 resíduos de aminoácidos e nos isolados Pb03 e Pb18 por 67 resíduos cada. Também há notáveis variações nas regiões 5’UTR e 3’UTR do gene PbCOX8 entre os isolados.

O gene PbCOX9 foi localizado no genoma dos três isolados entretanto há um grande diferença entre as proteínas preditas através da análise dos genomas e a proteína estudada através do transcrito de EST (EST-VP1-Pb30001-209C04) depositada sob o número de acesso (AY603792). Além disso, no isolado Pb18 encontramos esta proteína em dois lócus distintos no cromossomo 05 [(Supercontig 8: 834464-835888 - (122 aa)) e (Supercontig 8: 833321-834882 + (174 aa))]. O número de íntrons também variando entre os dois lócus (3 e 5, respectivamente).

O números de resíduos (62aa) preditos para a proteína PbCox9 estudada (AY603792 Bandeira e Nobrega, 2008) está mais próximo das proteínas preditas nos genomas dos isolados Pb01 (53aa) e Pb03 (62aa).

O gene PbCOX11 foi inicialmente identificado no clone RST-RC2-Pb30004-018D01 em um fragmento de aproximadamente 2800bp. A região codificadora do gene PbCOX11 está depositada no banco de dados do GenBank/NCBI sob o numero de acesso EF679211. Análise da seqüência do fragmento demonstrou claramente a presença de três íntrons neste gene. 
Além do gene $\mathrm{PbCOX11}$ outra fase aberta de leitura esta presente neste fragmento. A proteína predita possui alta similaridade com uma subunidade “C subunit Rfc5” de um fator de replicação de DNA. A região intergênica está em torno de 0,5Kb.

A análise das seqüências genômicas dos três isolados de P.brasiliensis confirma os resultados obtidos com o estudo do clone RST-RC2-Pb30004-018D01, indicando que o gene PbCOX11 encontra-se bem conservado em relação ao número de íntrons (03) entre os três isolados e o número de resíduos (253aa) nas proteínas preditas e a proteína estudada (EF679210) a partir de amplificação direta por PCR a partir de cDNA Poli(T).

O gene PbCOX12 também apresenta-se bem consistente em relação ao número de íntrons (04) entre os três isolados e o número de resíduos (92aa) nas proteínas preditas a partir de análise dos genomas. Entretanto, a proteína estudada através do transcrito da EST003252 do isolado Pb01 (AY603794) apresenta 141 resíduos. Estas observações sugerem o processamento incompleto do transcrito da EST003252 estudado anteriormente.

O gene PbCOX13 estudado através do transcrito da EST CN243928-1 do isolado Pb01 codifica para um proteína com 142 resíduos de aminoácidos (DQ003716). Este número de resíduos também é predito através da análise da seqüência genômica deste isolado ( $\mathrm{Pb} 01)$ bem como no isolado Pb18, ambos sendo interrompidos por quatro (04) íntrons. Já no isolado Pb03 ocorre uma variação tanto no número de íntrons (03) quanto no número de resíduos preditos (132aa).

O gene PbCOX15 apresenta apenas um íntrons em todos os isolados. O número de resíduos preditos (491aa) também é exatamente o mesmo no três isolados inclusive na proteína PbCox15 estudada através do transcrito da EST EST006267 do isolado Pb01 (DQ003717).

No gene PbCOX16 observa-se um intron em todos os isolados analisados e número de resíduos estimados para a ORF (135aa) é o mesmo em todos eles confirmando os resultados obtidos no estudo da EST-RC2-PbNEW1-172D04 do isolado Pb18 (AY842443). Observamos que, no entanto as regiões 5' UTR e 3’UTR são diferentes nos três isolados.

O gene PbCOX17 apresenta apenas dois (02) íntrons em todos os isolados e o número de resíduos preditos (78aa) também é constante no três isolados inclusive na proteína PbCox17 estudada através do transcrito da EST EST006191do isolado Pb01 (DQ003718). Semelhante ao gene $P b C O X 16$, também variações nas regiões 5'UTR e 3’UTR nos três isolados.

O gene PbCOX19 com dois (02) íntrons em todos os isolados, apresenta variação no tamanho da proteína predita entre os isolados sugerindo a ocorrência de splicing alternativo. 
A análise das seqüências dos genomas dos isolados Pb01 e Pb18 indica a presença da proteína PbCox19 com 107 resíduos de aminoácidos. Também se observa variação nas regiões 5’UTR e 3’UTR do gene em todos os isolados. A proteína predita a partir do estudo da EST EST014900 do isolado Pb01 também é constituída por 107 resíduos (DQ003414). Já no isolado Pb03 a proteína predita é constituída por apenas 95 resíduos de aminoácidos.

Na análise da seqüência do transcrito da EST008699 referente ao gene PbCOX23 frente à seqüência genômica dos isolados de $P$. brasiliensis observou-se que a proteína predita nos dados genômicos de P. brasiliensis seria bem maior que as proteínas homólogas de outros fungos e até mesmo que a proteína predita (76 aa) no transcrito estudado através do clone da EST008699. Observou-se que esta é constituída por 254 resíduos no isolado Pb18 e 432 no Pb01. Não foi identificada em Pb03.

No caso do isolado Pb18 a análise genômica do gene PbCOX23 indica que este apresenta oito (08) íntrons (Fig. 47A) enquanto que a região genômica referente ao transcrito EST008699 (DQ402182) estudado apresenta somente três íntrons. A proteína predita no estudo da EST alinha exatamente com a porção C-terminal da proteína predita no genoma (Fig. 47B) sugerindo que o transcrito estudado possa ser resultado de uma seqüência de cDNA incompleto, que não contem a porção N-terminal de 179 resíduos, ou ainda que proteína possa ser expressa de forma fusionada a outras proteínas ou então processada póstraducionalmente. 


\section{A Feature Map: Paracoccidioides brasiliensis Pb18 Supercontig 4}

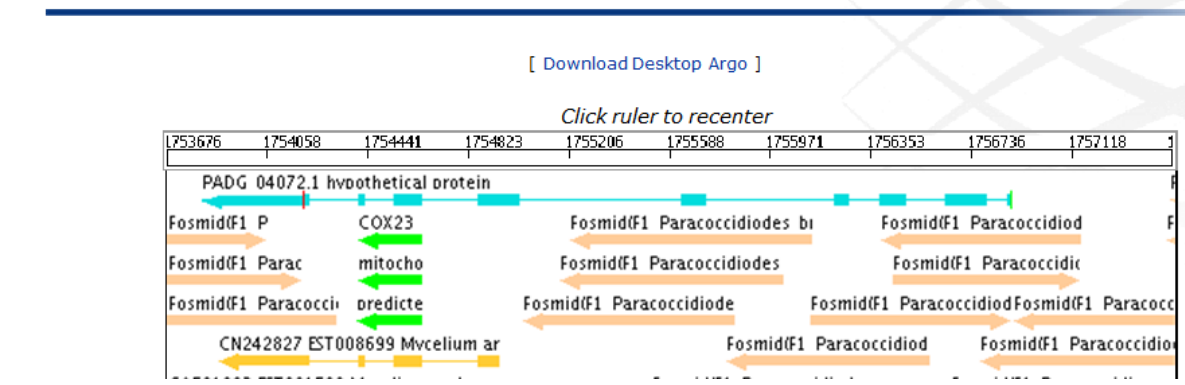

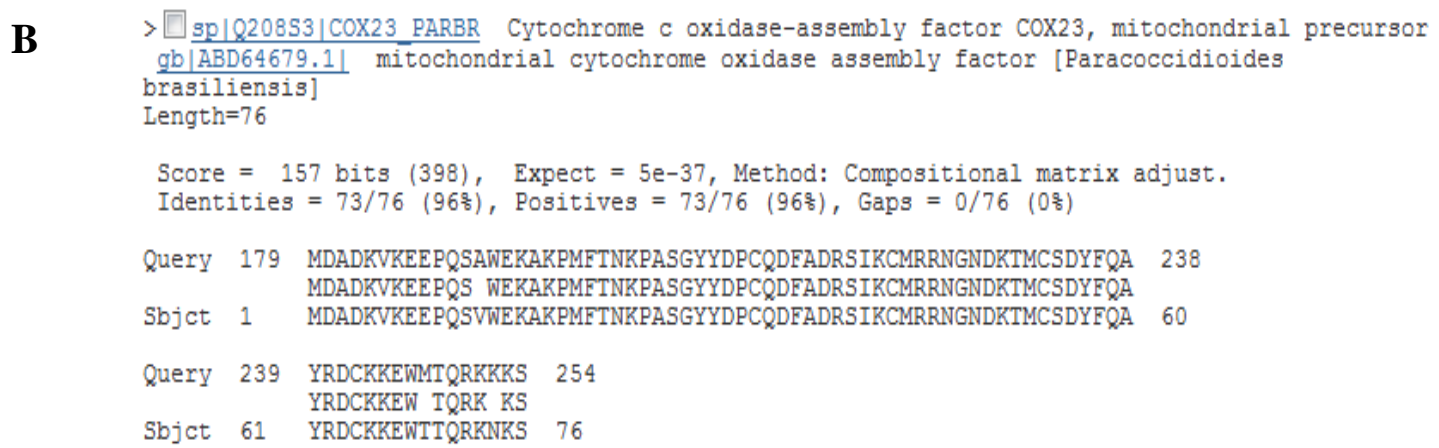

FIGURA 47: PbCox23p predita no genoma do isolado Pb18.

(A) Indica os íntrons (em azul) da proteína PbCox23p predita no genoma do isolado Pb18. (B) Análise comparativa da proteína PbCox23p estudada através do transcrito da EST008699 e a proteína predita no genoma do isolado Pb18.

Sabe-se que a Cox23p faz parte de uma família de proteínas que apresentam um domínio conservado denominado $\mathrm{CHCH}$ ([coiled coil 1]-[helix 1]-[coiled coil 2]-[helix 2] domain ) este domínio também é encontrado em outras proteínas mitocondriais como Cox17p, Cox19p e a proteína ribossomal Mrp10. Este domínio também é observado na proteína predita P. brasiliensis.

O gene PbPET100 como já mencionada anteriormente apresenta variação entre os isolados Pb01 e Pb18. Em ambos os isolados este gene está dividido por um (01) íntron. A proteína identificada no transcrito EST-RC2-Pb30001-125H07 (AY603796) do isolado Pb18 apresenta 103 resíduos de aminoácidos enquanto que a proteína predita pela análise do genoma apresenta 105 resíduos. A diferença de dois (02) resíduos de aminoácido é decorrente da presença de uma repetição GGGAGT a mais na proteína predita, ou seja, no transcrito existem três (03) dessas repetições enquanto que na proteína predita existem quatro (04).

No isolado Pb01 a proteína PbPet100 apresenta 101 resíduos sendo que os resíduos a menos também são decorrentes no números de repetições GGGAGT. Os íntrons dos dois 
isolados estão presentes na mesma posição entretanto a seqüência dos mesmos também apresenta variações. Há grande diferença também nas regiões 5’UTR e 3’UTR do gene PbPET100 dos dois isolados (Pb01 e Pb18).

Como as repetições GGGAGT não se encontram em regiões de borda intrônica a diferença do numero de repetições das mesmas entre a proteína predita e a proteína estudada (AY603796) pode ser resultado de um erro de transcrição.

O gene PbPET112 estudado no transcrito EST-VP1-Pb30001-203E03 codifica para uma proteína com 603 resíduos de aminoácidos (DQ402183) enquanto que a proteína PbPet112p predita no genoma do isolado Pb18 é constituída por 661 resíduos. A análise comparativa das duas proteínas indica que a proteína estudada (DQ402183) é resultado de um cDNA incompleto que não possui 58 resíduos de aminoácidos na região N-terminal. Este gene está dividido por quatro (04) íntrons no isolado Pb18.

No isolado Pb01 a proteína PbPet112p predita é constituída por 775 resíduos de aminoácidos sendo interrompida por cinco (05) íntrons. Já no isolado Pb03 não temos uma predição finalizada. Portanto, a análise das seqüências genômicas dos isolados Pb01 e Pb18 do fungo $P$. brasiliensis indicam variação na região codificadora do gene PbPET112 desses dois isolados.

No estudo do gene PbPET191 amplificou-se o gene diretamente do genoma de $P$. brasiliensis utilizando os olinucleotídeos específicos (senso: 5'CGTGCGGAGCTCGATTGTGTT-3' e anti-senso: 5'-TCCGTTCTGCAGCTCCCCC-3') que foram desenhados com base na seqüência da EST EST013844 (Felipe et al., 2003). Amplificamos um fragmento com 634 pares de base contendo o gene PbPET191 que está interrompido por dois (02) introns que codificam para uma proteína com 123 resíduos de aminoácidos. A seqüência expressa deste gene ainda não foi clonada, porém a análise da seqüência genômica dos três isolados de P. brasiliensis ( $\mathrm{Pb01}$, Pb03 e Pb18) confirma tanto a presença dos dois íntrons quanto o tamanho da proteína predita que é igual nos três isolados com 123 resíduos.

O estudo da estrutura genômica do gene PbMSS51 foi inicialmente acessada através do estudo do clone genômico RST-VP1-Pb00003-010H04 que contém um fragmento genômico com cerca de 2,4kb. A comparação entre a seqüência expressa (EST-VP1-Pb00001166F10) e a seqüência do fragmento genômico indicava que este gene teria um intron. No entanto, a comparação entre a seqüência expressa (DQ003715) e a seqüência do fragmento genômico indicou que o gene PbMSS51 não esta completo faltando aproximadamente 235bp da região terminal 3’ do gene onde verificou-se presença de mais um íntron posteriormente. 
Através da análise das seqüências genômicas dos três isolados (Pb01, Pb03 e Pb18) verificou-se que o gene PbMSS51 está interrompido por dois (02) íntrons, sendo o mesmo padrão observado em todos os isolados. Também não se observa a ocorrência de variação no tamanho da proteína predita com 514 resíduos entre os isolados e a proteína estuda através do transcrito de EST-VP1-Pb00001-166F10 (DQ003715).

Na definição da estrutura genômica do gene PbOXA1 trabalhou-se inicialmente com o clone genômico RST-VP1-Pb50003-024E10 que é constituído por aproximadamente 1942bp, verificando-se a presença dois (02) íntrons. Na região 5' deste fragmento observa-se a presença de 81bp que não está presente no clone EST-VP1-Pb30001-205H03. Nesta região adicional (81bp) verifica-se um condon iniciador ATG em fase com a ORF deste gene acrescentando mais 58 resíduos à proteína PbOxa1p totalizando uma proteína com 532 resíduos diferentemente da proteína com 474 resíduos (GenBank/NCBI - DQ836715) identificada através do clone de EST. Numa analise mais cuidadosa da região 5'da EST verificou-se 31pb diferentes nesta região da seqüência expressa. Este resultado poderia indicar que: ou a seqüência expressa (EST-VP1-Pb00001-205H03) não contém a região codificadora completa do gene PbOXA1, ou temos um caso de gene de cópia dupla no genoma e neste caso o fragmento genômico identificado (RST-VP1-Pb50003-024E10) não corresponde ao lócus da seqüência expressa (EST-VP1-Pb30001-205H03) estudada.

A análise da seqüência genômica dos três isolados confirma a presença dos dois íntrons no isolado Pb18, sendo a proteína predita com 514 resíduos de aminoácidos. No isolado Pb01, o gene PbOXA1 está interrompido por três (03) íntrons sendo constituída por 644 resíduos de aminoácidos. Já no isolado Pb03 este gene também está interrompido por três íntrons entretanto a proteína predita é constituída por 505 resíduos de aminoácidos. Os genes dos isolados Pb01 e Pb18 são mais parecidas entre si, incluindo a região 3' terminal e os dois primeiros íntrons do isolado Pb03. A partir do segundo íntron ocorre diferenciação. Já o isolado Pb01 é o mais distante tendo as seqüências intrônicas bem diferentes.

A estrutura genômica do gene PbSCO1 foi acessada inicialmente no clone RST-VP1Pb50003-038F06 com aproximadamente 2115bp. Nesta análise identificou-se a presença de dois (02) íntrons sendo que o segundo está em fase com a fase aberta de leitura do gene PbSCO1. Neste clone o gene não esta completo faltando uma porção da região 5' do gene. A análise das seqüências genômicas dos três isolados (Pb01, Pb03 e Pb18) de P. brasiliensis indica que nos isolados Pb01 e Pb18 o gene PbSCO1 está interrompido por dois íntrons e a proteína predita é constituída por 316 resíduos de aminoácidos, diferente da que foi previamente observada (304 resíduos) no estudo do transcrito obtido através de amplificação 
por PCR (EF679209). Esta diferença se encontra na região N-terminal da proteína. Entretanto, o códon iniciador correspondente com o códon iniciador da proteína predita na seqüência genômica, também está presente no transcrito amplificado por PCR, porém não esta em fase com a região codificadora e, portanto, a proteína previamente predita (EF679209) com 304 resíduos está iniciando no segundo condon ATG do gene. Provavelmente ocorreu algum erro na seqüência durante a reação de amplificação por PCR do gene. No isolado Pb03 ainda não há uma predição finalizada.

\subsection{Expressão Relativa De Genes Nucleares De $P$. brasiliensis Durante O Período De Transição Morfológica Induzida Pela Mudança Da Temperatura}

Verificar o padrão de expressão dos genes nucleares de $P$. brasiliensis envolvidos na expressão do complexo da citocromo c oxidase mitocondrial, nas formas de levedura, micélio e nas formas intermediárias do fungo, durante o período de transição morfológica, induzida pela mudança de temperatura do meio de crescimento foi mais um dos objetivos deste trabalho, considerando que a fosforilação oxidativa seria desacoplada durante a transição morfológica de P. brasiliensis de micélio para levedura (Medoff et al., 1987) .

A expressão do complexo da citocromo c oxidase mitocondrial funcional depende da expressão coordenada de genes mitocondriais e nucleares. Além das subunidades estruturais (oito) que formam o complexo, outras dezenas de produtos gênicos são necessárias para garantir a montagem funcional deste complexo.

Para quantificação do nível de expressão de mRNAs estáveis destes alvos específicos utilizamos reação de PCR em tempo real (RT-PCR) baseada na emissão de fluorescência e o método $2^{\text {-DDCt }}$ (Livak e Schmittgen 2001) para a quantificação relativa. De acordo com este método $\left(2^{-\mathrm{DDCt}}\right)$ a expressão de cada gene é subtraída da expressão do gene utilizado como controle endógeno $(\Delta \mathrm{Ct})$ e desta forma pode-se padronizar a quantidade inicial de amostra utilizada em cada experimento. Esta técnica é a mais utilizada atualmente para a caracterização da expressão de genes alvos através da comparação do nível dos respectivos mRNAs em diferentes populações de amostras (Orlando et al., 1998). Como controle endógeno utilizou-se o gene PbeIF3 (Nunes et al., 2005). A amostra inicial (0h ou levedura) foi escolhida como agente calibrador ou referencial à expressão de cada amostra obtida após as mudanças de temperatura (5h, 10h, 24h, 48h e 120h) até a completa transição morfológica. 
As análises da expressão relativas dos genes nucleares de $P$. brasiliensis envolvidos na biosíntese do complexo da citocromo c oxidase foram realizadas utilizando-se duas tecnologias distintas, a tecnologia TaqMan e a de SYBR Green.

A lista dos "primers" e "probes" dos genes alvos (PbCOX2, PbCOX4, PbCOX5A, PbCOX6, PbCOX9, PbCOX12, PbCOX16, PbCOX17 e PbCOX19) está descrita na Tabela 3. Os "primers" e "probes” dos genes alvos foram obtidos através do sistema Assay-byDesignSM system (Applied Biosystems) enquanto que os “primers” e a "probe” para o controle endógeno (PbeIF3) foi obtido pela sistema de Custom TaqMan ${ }^{\circledR}$ MGB ${ }^{\mathrm{TM}}$ Probe (Applied Biosystems). Estes foram os genes analisados com a tecnologia TaqMan. Já as seqüências dos primers dos demais genes estudados através da tecnologia de SYBR Green estão descritas na lista de iniciadores na seção de material e métodos.

Ao todo foram analisados a expressão de vinte e quatro (24) genes sendo o PbCOX2 representante de uma subunidade mitocondrial do complexo. O genes nucleares $P b C O X 4$, PbCOX5A, PbCOX6, PbCOX8, PbCOX9, PbCOX12 e PbCOX13 representantes de subunidades estruturais e os genes PbCOX11, PbCOX15, PbCOX16, PbCOX17, PbCOX19, PbCOX23, PbOXA1, PbPET100, PbPET112, PbMSS51 e PbSCO1 também nucleares, representantes de subunidades que auxiliam na montagem e manutenção do complexo COX funcional. Além dos genes envolvidos no complexo da COX também foi analisado a expressão de representantes de genes de outros complexos da cadeia respiratória mitocondrial: O gene PbNDI1 do complexo da NADH-Coenzima Q-redutase (complexo I). Os genes PbRIP1 e PbQCR7 do complexo da ubiquinol citocromo c redutase (complexo III), os genes PbATP4 e PbATP7 complexo da ATP-sintase mitocondrial.

Após a normalização dos resultados da reação de RT-PCR (PCR em tempo real) contra o gene PbeIF3, utilizado como controle endógeno, os resultados foram resumidos em gráficos como mostram as figuras (48A a 71A). A observação dos resultados mostra que existe uma modulação da expressão de todos os genes durante o processo de transição morfológica do fungo. Pode-se observar uma variação no comportamento de alguns genes em relação à maioria entretanto a visão geral indica que ocorre aumento da expressão quando a temperatura é aumentada de $25^{\circ} \mathrm{C}$ para $37^{\circ} \mathrm{C}$ e diminuição quando a temperatura é baixada de $37^{\circ} \mathrm{C}$ para $25^{\circ} \mathrm{C}$.

Considerando que os mRNAs utilizados para as reações de qRT-PCRs foram todos quantificados, foi realizada também a análise da expressão desses genes sem a normalização com o controle endógeno. Embora se observe um mesmo padrão quando a temperatura é elevada, ou seja, aumento da expressão, pode ser observado um padrão diferenciado na 
expressão destes genes quando a temperatura é diminuída de $37{ }^{\circ} \mathrm{C}$ para $25{ }^{\circ} \mathrm{C}$ em relação à analise utilizando o PbeIF3 como controle endógeno (Fig. 48B a Fig. 71b). Nesta situação geralmente ocorre um aumento da expressão durante as primeiras 10 horas seguida de um progressivo declínio no restante do período analisado.

A análise da expressão do gene PbeIF3 durante o período da transição morfológica mostrou que este gene também sofre modulação (Fig. 72) durante este processo e que portanto, não é apropriado para o uso como controle endógeno. Diante deste resultado consideramos a expressão dos genes estudados, a partir da análise sem o controle endógeno (Fig. 48B a Fig. 71B).

Portanto, durante a transição morfológica de levedura para micélio induzida por mudança da temperatura do meio de crescimento do fungo $P$. brasiliensis ocorre um aumento da expressão de todos os genes analisados durante as primeiras 10 horas de diminuição da temperatura com progressivo declínio da expressão no restante do período.

Já quando a temperatura é aumentada de $25^{\circ} \mathrm{C}$ para $37^{\circ} \mathrm{C}$ na transição de micélio para levedura observa-se aumento contínuo da expressão da maioria dos genes durante todo o período da transição morfológica. As exceções são quanto aos genes PbNDI1 do complexo I e os genes codificadores de proteínas auxiliares da montagem e manutenção do complexo da COX, PbMSS51, PbPET112, PbCOX15, PbCOX16 e PbCOX17. Nestes genes observa-se ou um aumento discreto ou somente pequenas variações da expressão durante o período da transição. 
A

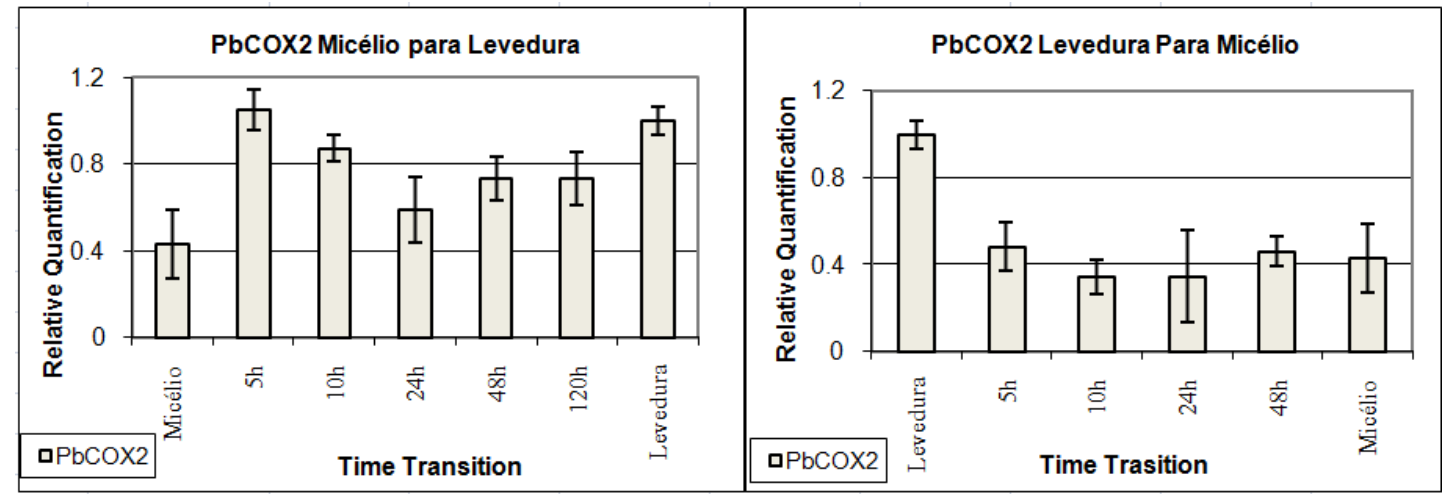

B

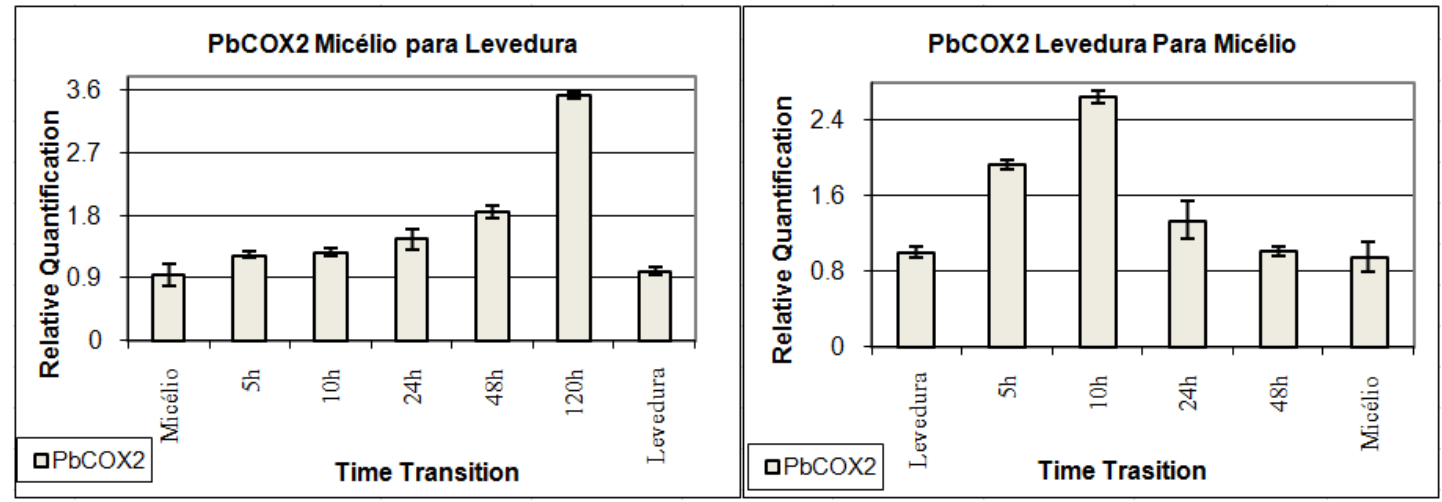

FIGURA 48: Expressão do gene $P b C O X 2$ durante a transição morfológica de $P$. brasiliensis.

induzida pela mudança da temperatura. A: Com controle endógeno. B: Sem controle endógeno. 
A
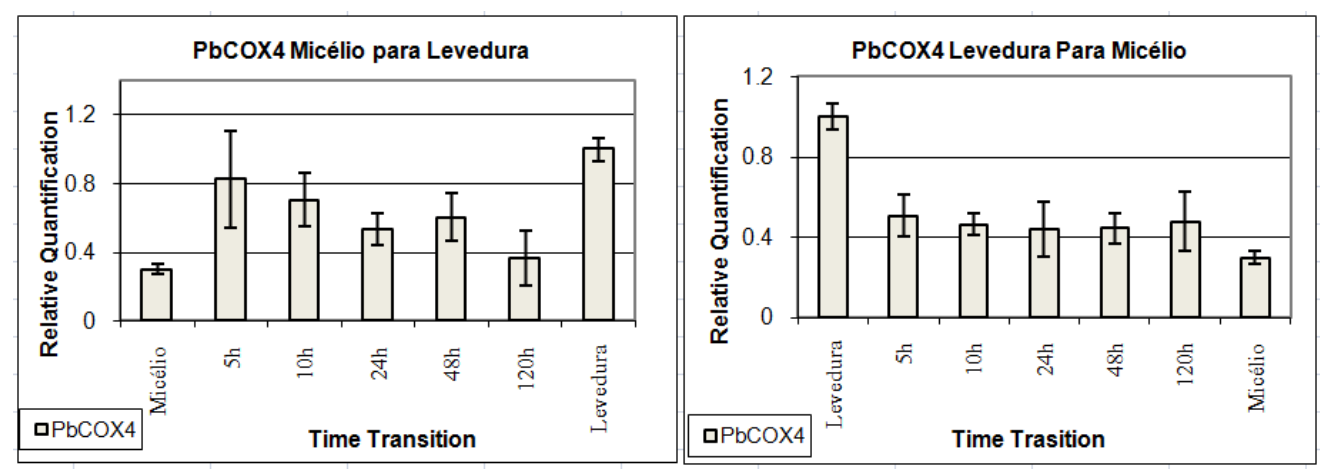

B

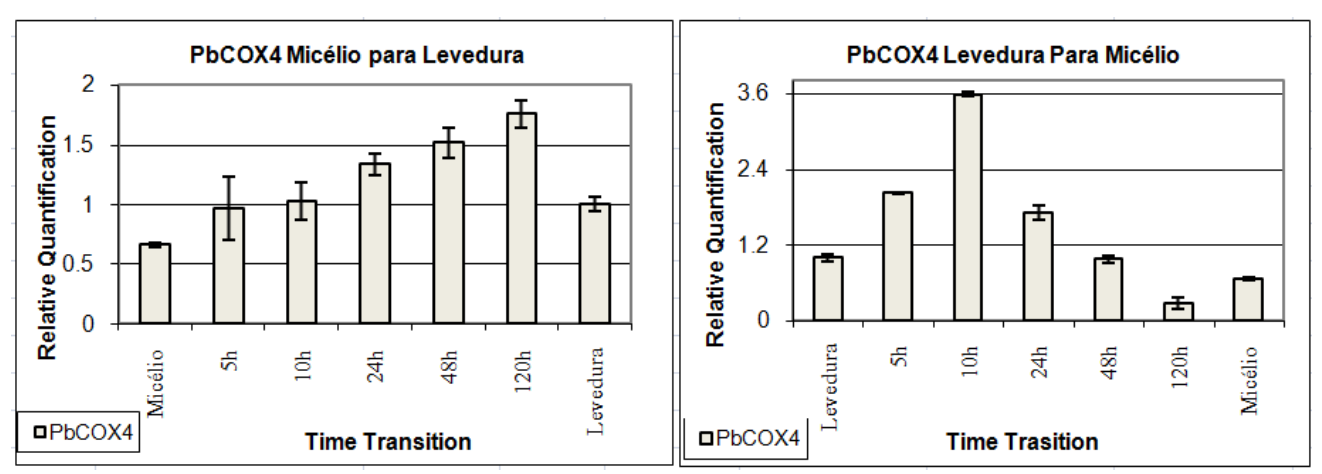

FIGURA 49: Expressão do gene $P b C O X 4$ durante a transição morfológica de $P$. brasiliensis. induzida pela mudança da temperatura. A: Com controle endógeno. B: Sem controle endógeno.

A
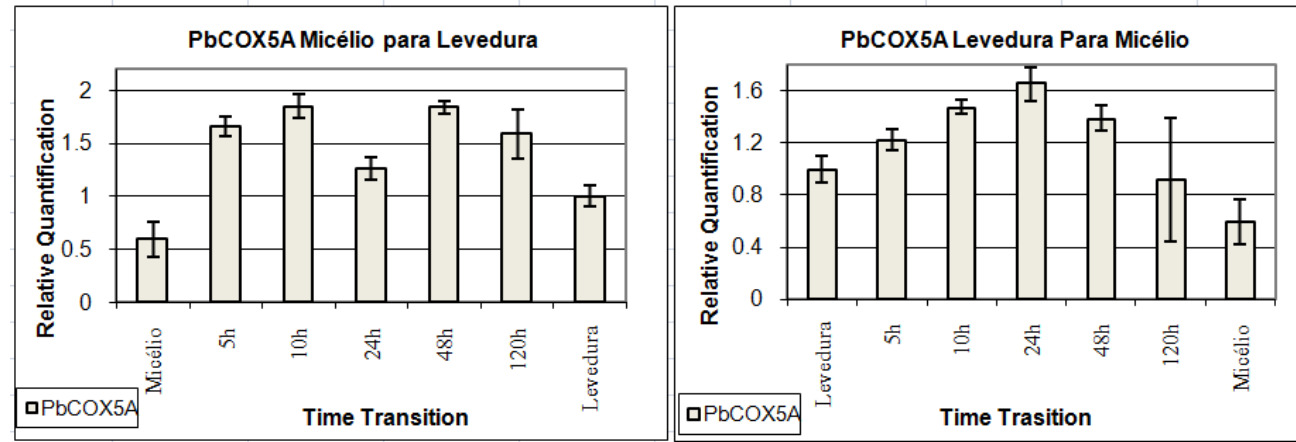

B

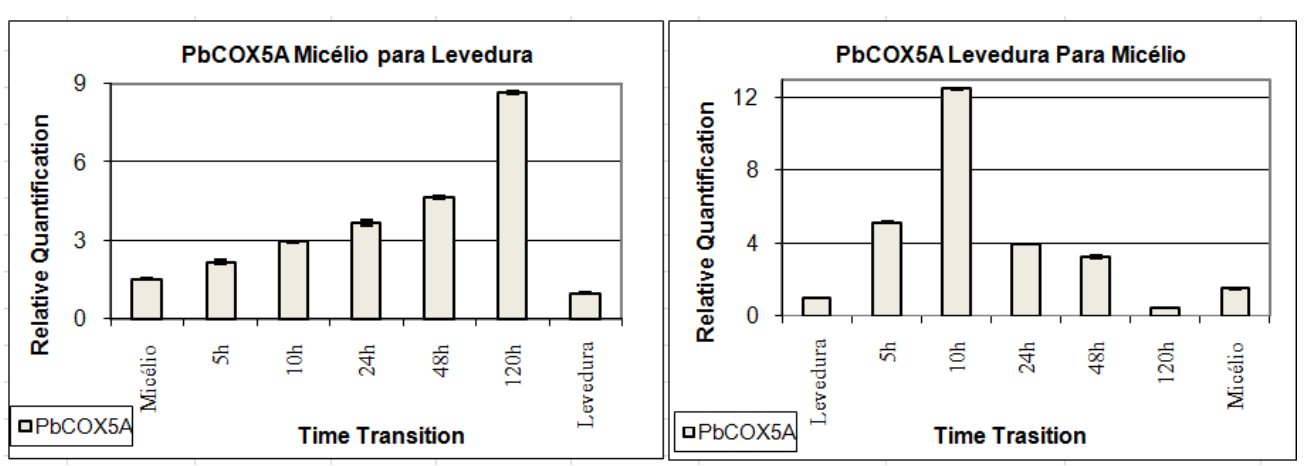

FIGURA 50: Expressão do gene PbCOX5A durante a transição morfológica de $P$. brasiliensis. induzida pela mudança da temperatura. A: Com controle endógeno. B: Sem controle endógeno. 
A
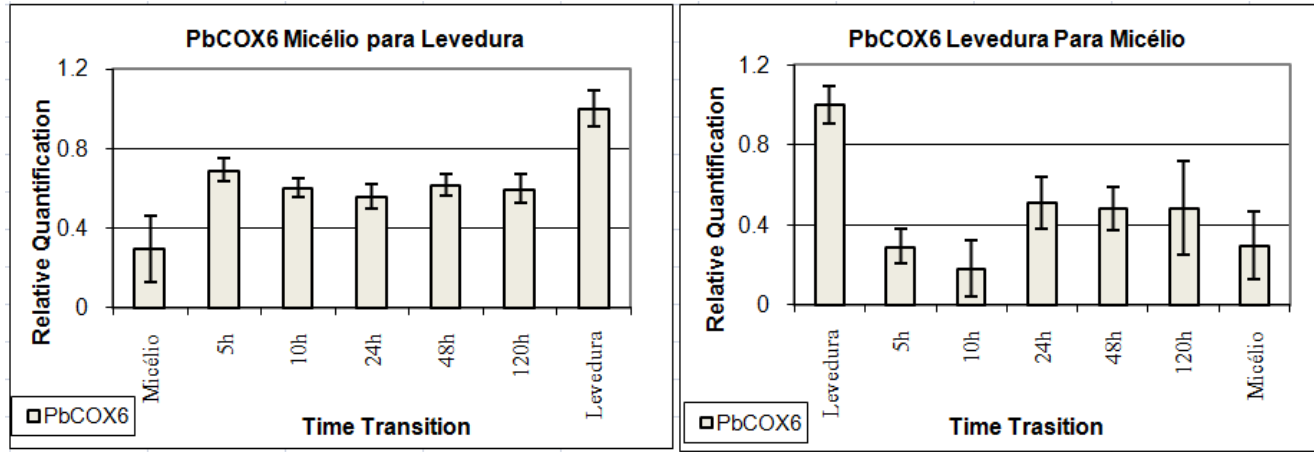

B
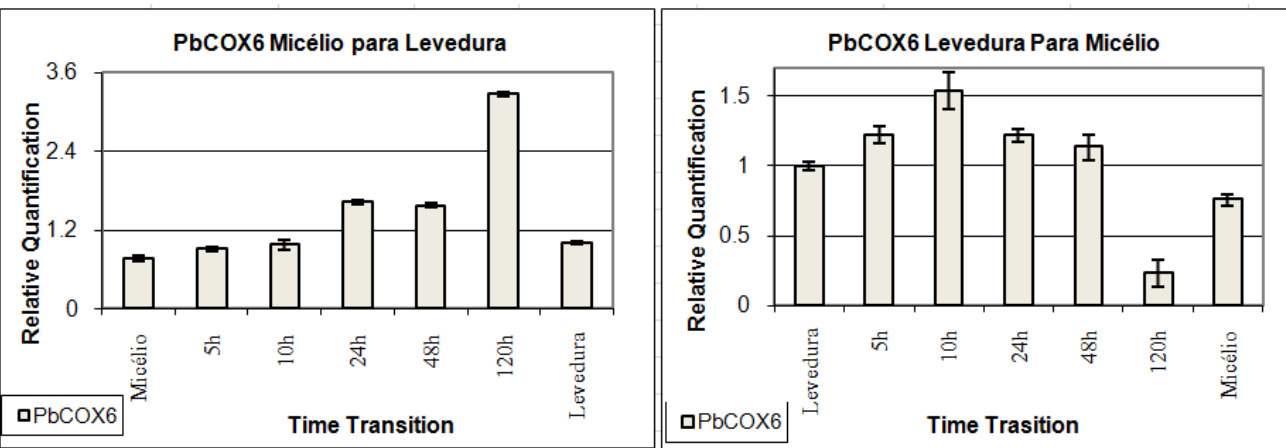

FIGURA 51: Expressão do gene PbCOX6 durante a transição morfológica de $P$. brasiliensis. induzida pela mudança da temperatura. A: Com controle endógeno. B: Sem controle endógeno.

A
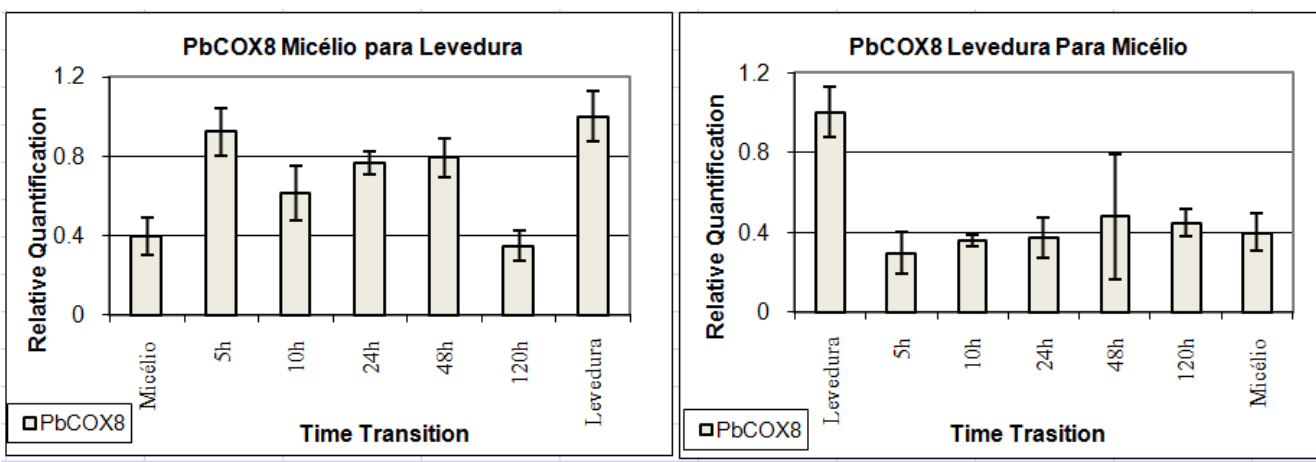

B

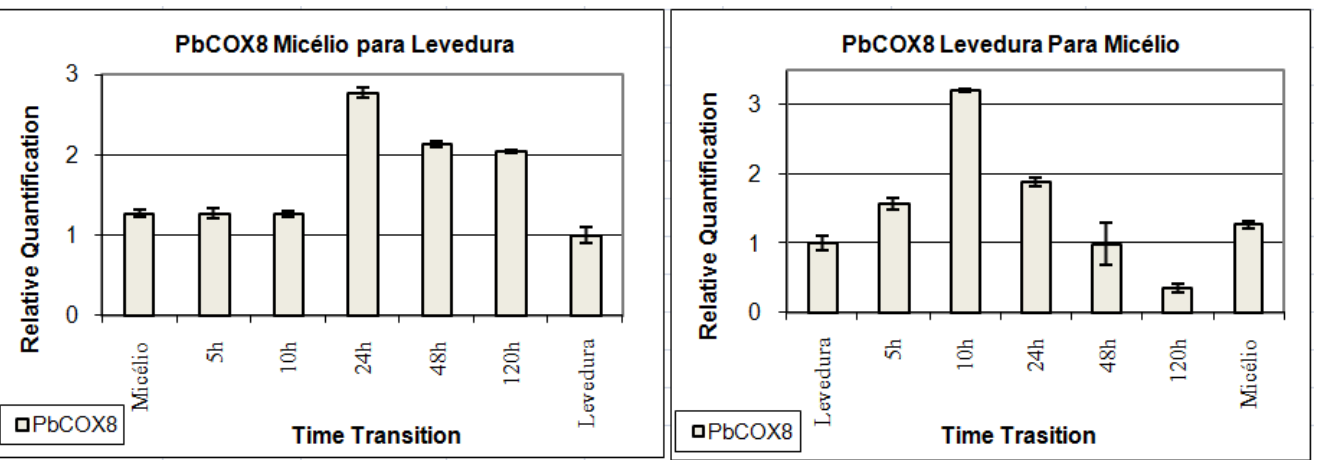

FIGURA 52: Expressão do gene $P b C O X 8$ durante a transição morfológica de $P$. brasiliensis.

induzida pela mudança da temperatura. A: Com controle endógeno. B: Sem controle endógeno. 
A

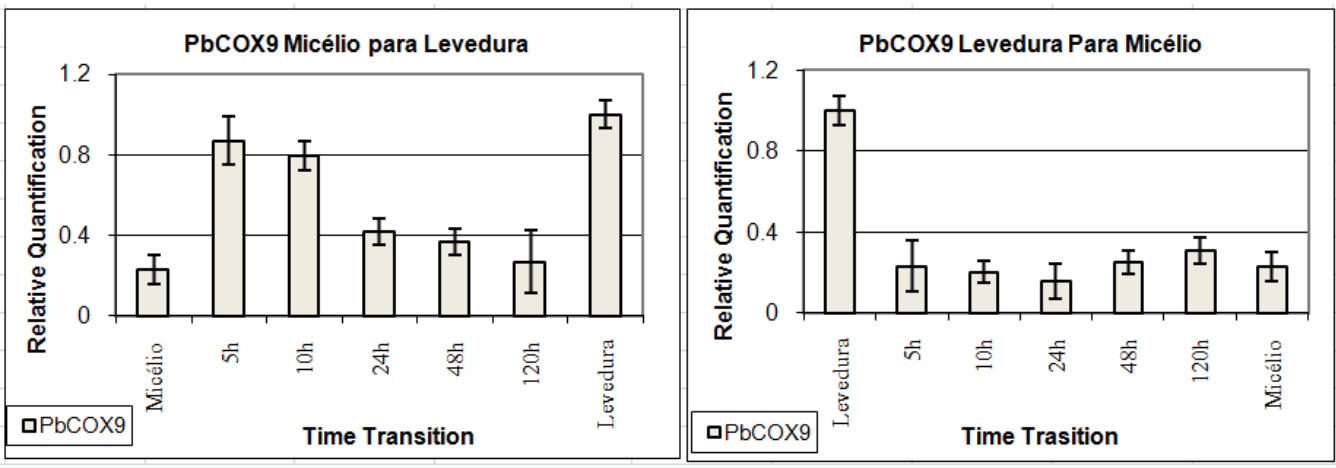

B

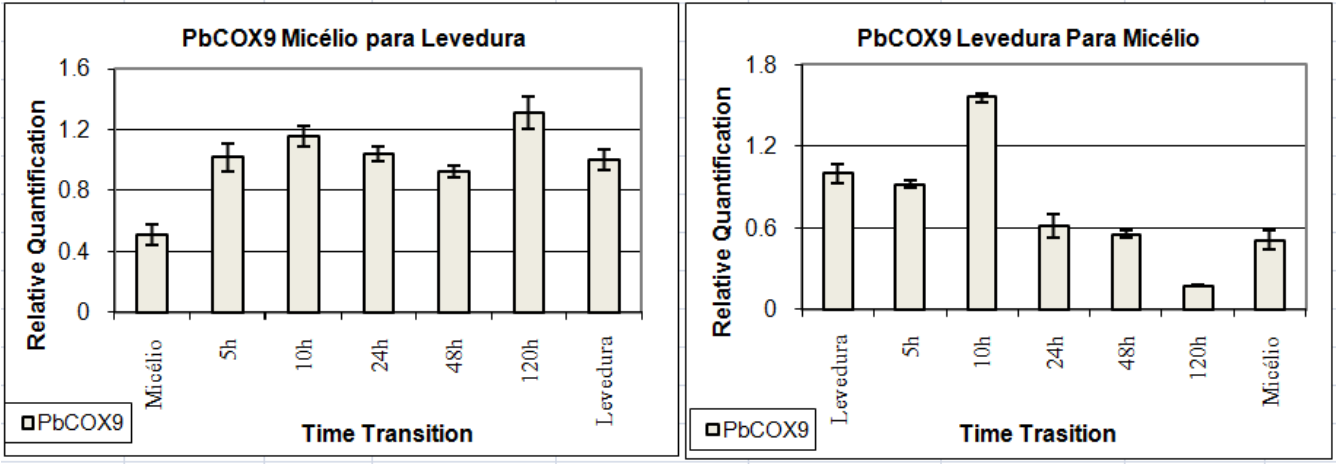

FIGURA 53: Expressão do gene $P b C O X 9$ durante a transição morfológica de $P$. brasiliensis. induzida pela mudança da temperatura. A: Com controle endógeno. B: Sem controle endógeno.

A
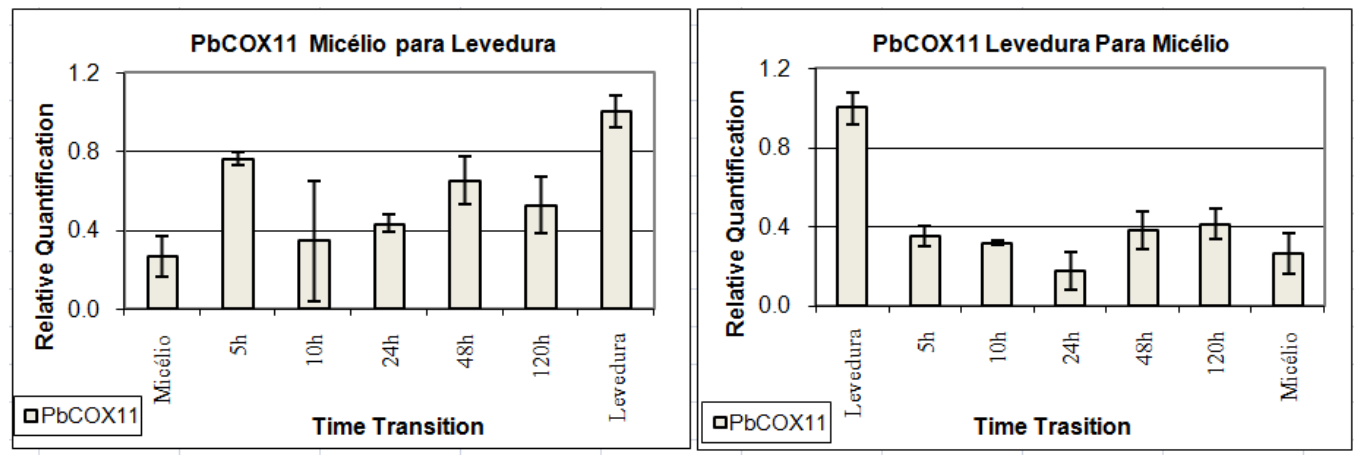

B
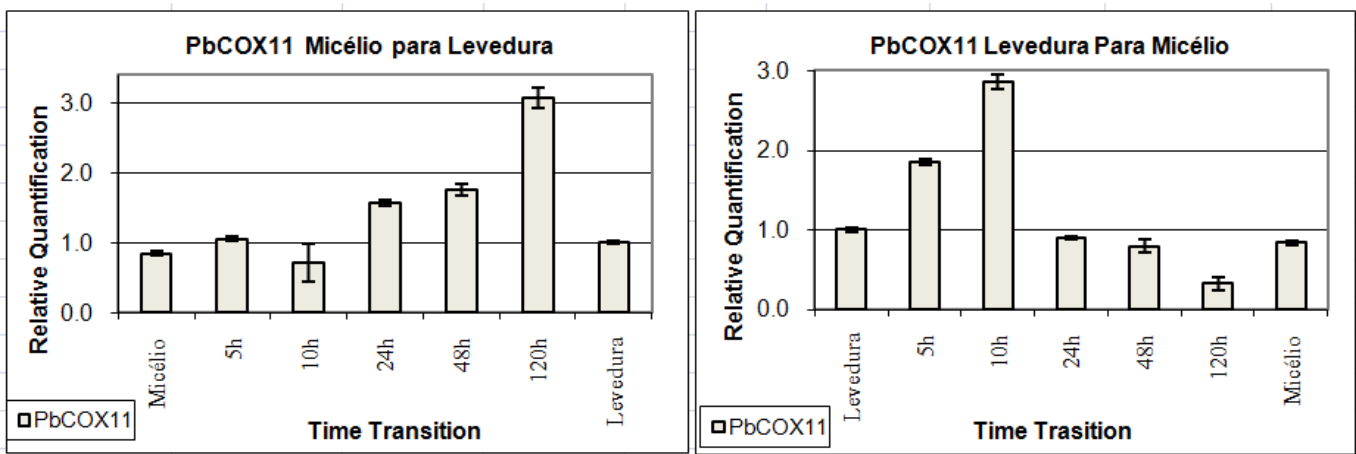

FIGURA 54: Expressão do gene $P b C O X 11$ durante a transição morfológica de $P$. brasiliensis. induzida pela mudança da temperatura. A: Com controle endógeno. B: Sem controle endógeno. 
A

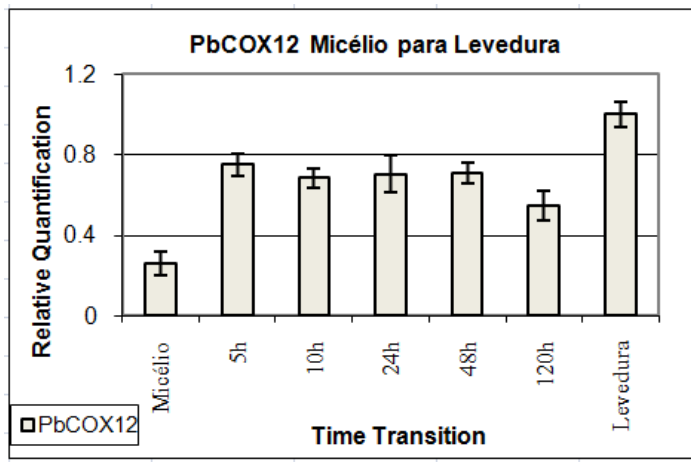

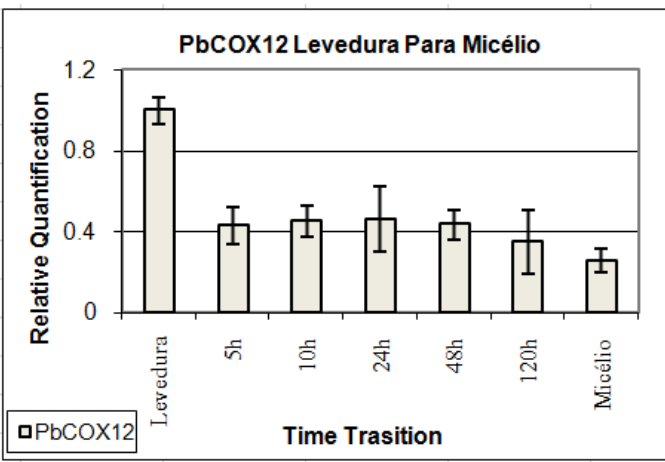

B
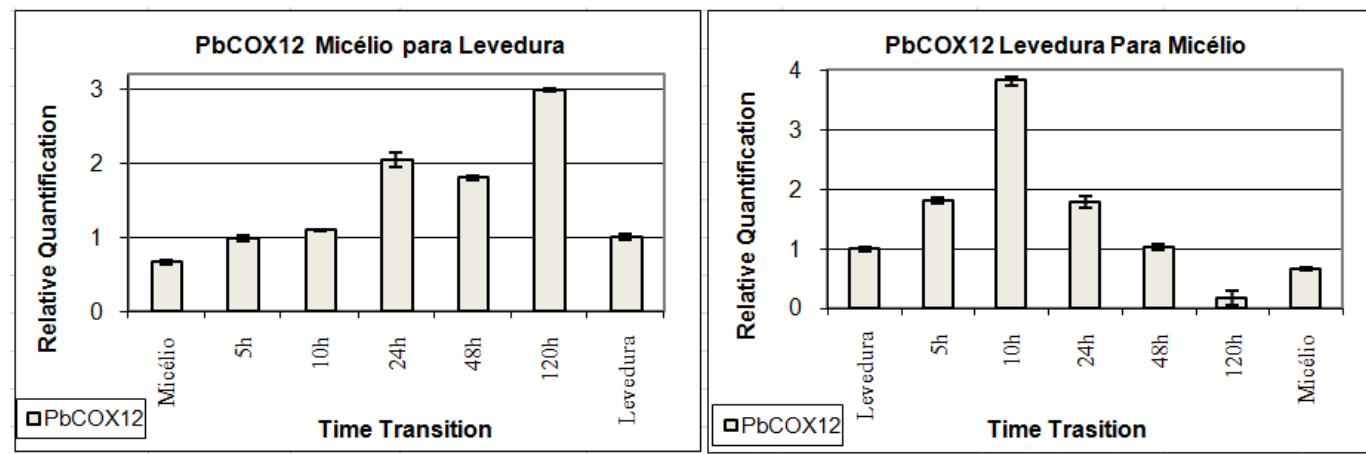

FIGURA 55: Expressão do gene PbCOX12 durante a transição morfológica de $P$. brasiliensis. induzida pela mudança da temperatura. A: Com controle endógeno. B: Sem controle endógeno.

A
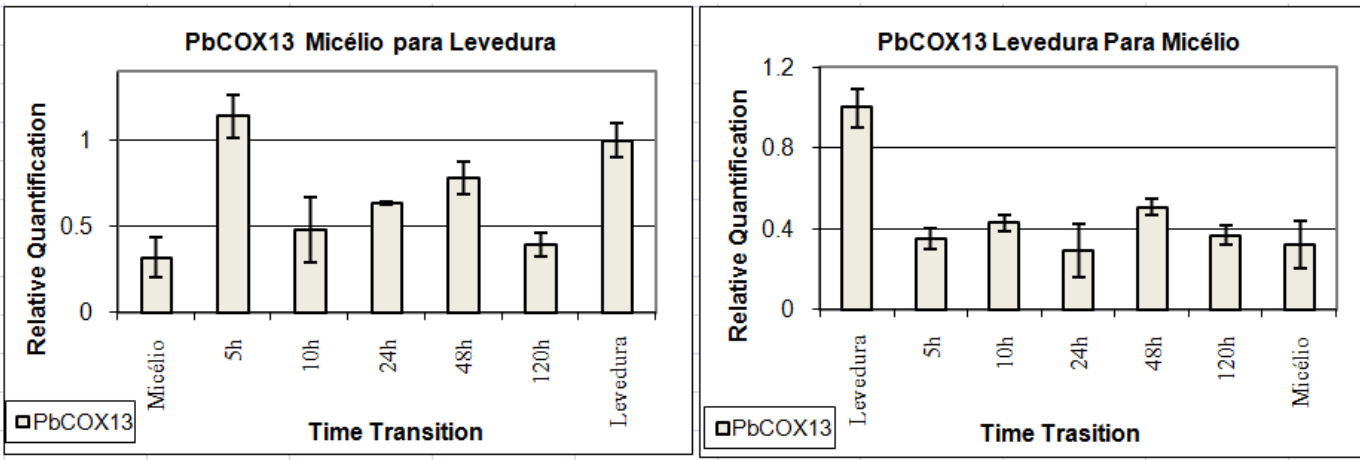

B
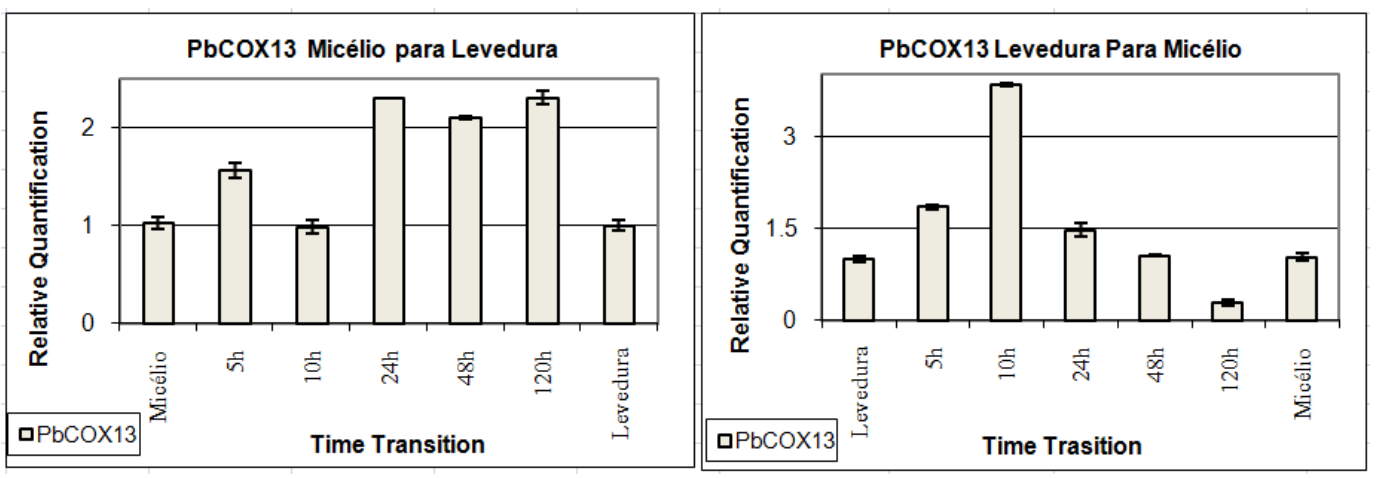

FIGURA 56: Expressão do gene PbCOX13 durante a transição morfológica de $P$. brasiliensis. induzida pela mudança da temperatura. A: Com controle endógeno. B: Sem controle endógeno. 
A

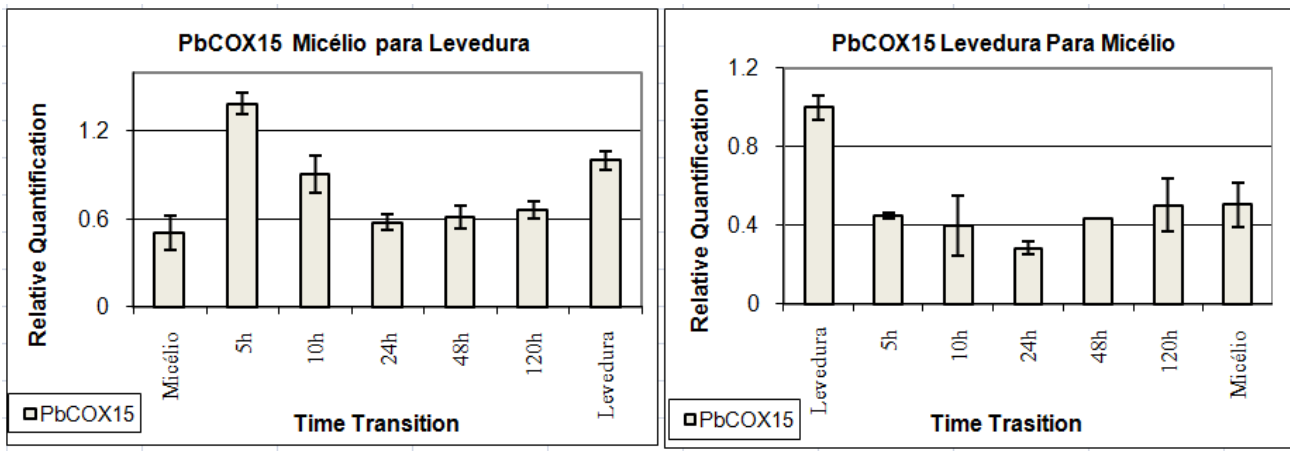

B

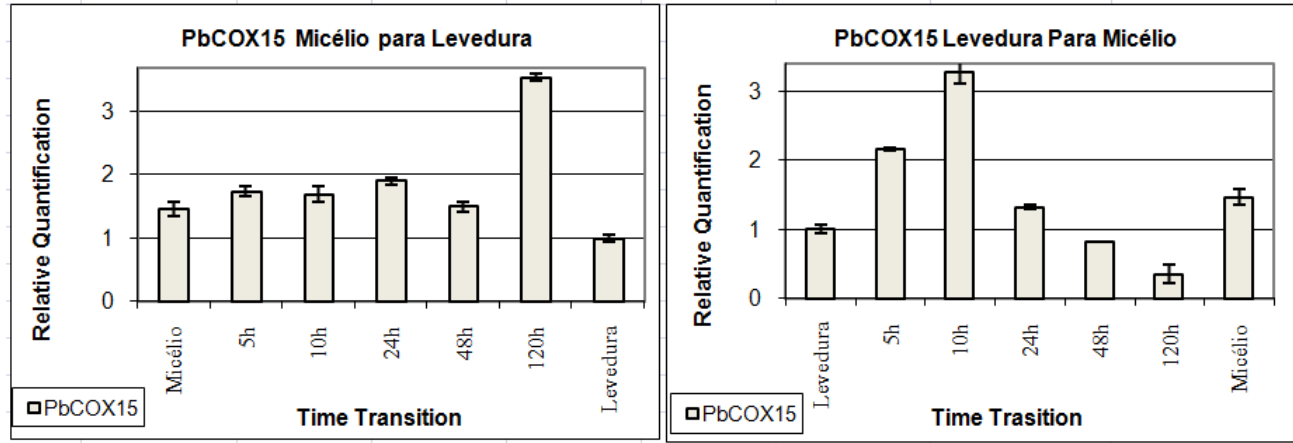

FIGURA 57: Expressão do gene $P b C O X 15$ durante a transição morfológica de $P$. brasiliensis. induzida pela mudança da temperatura. A: Com controle endógeno. B: Sem controle endógeno.

A

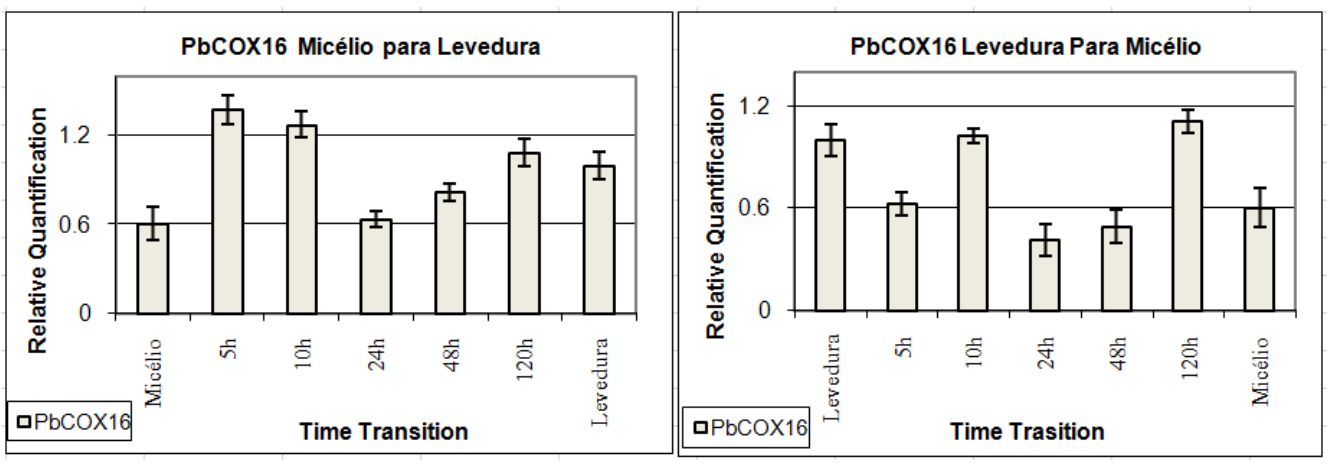

B

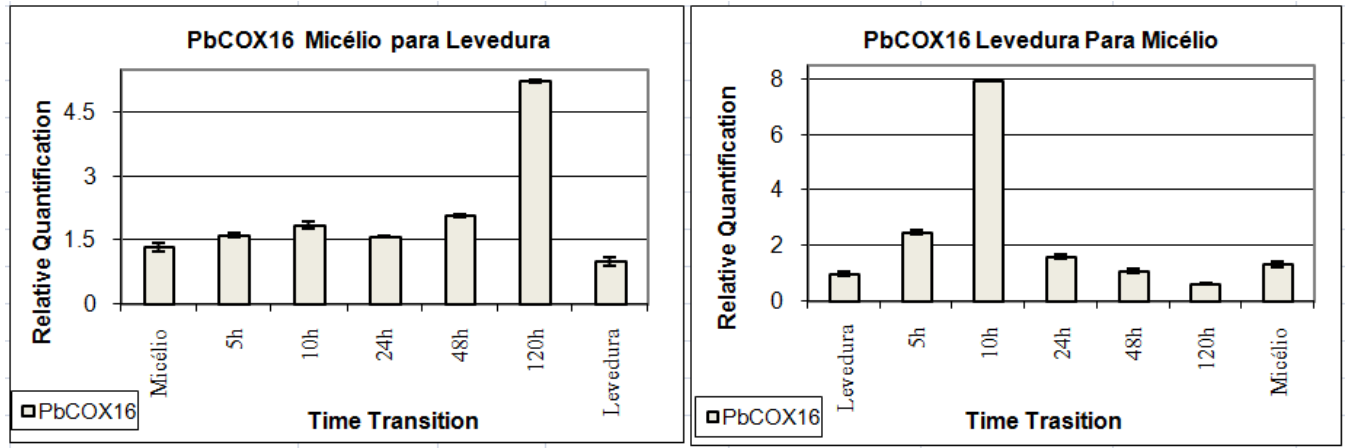

FIGURA 58: Expressão do gene PbCOX16 durante a transição morfológica de $P$. brasiliensis.

induzida pela mudança da temperatura. A: Com controle endógeno. B: Sem controle endógeno. 
A
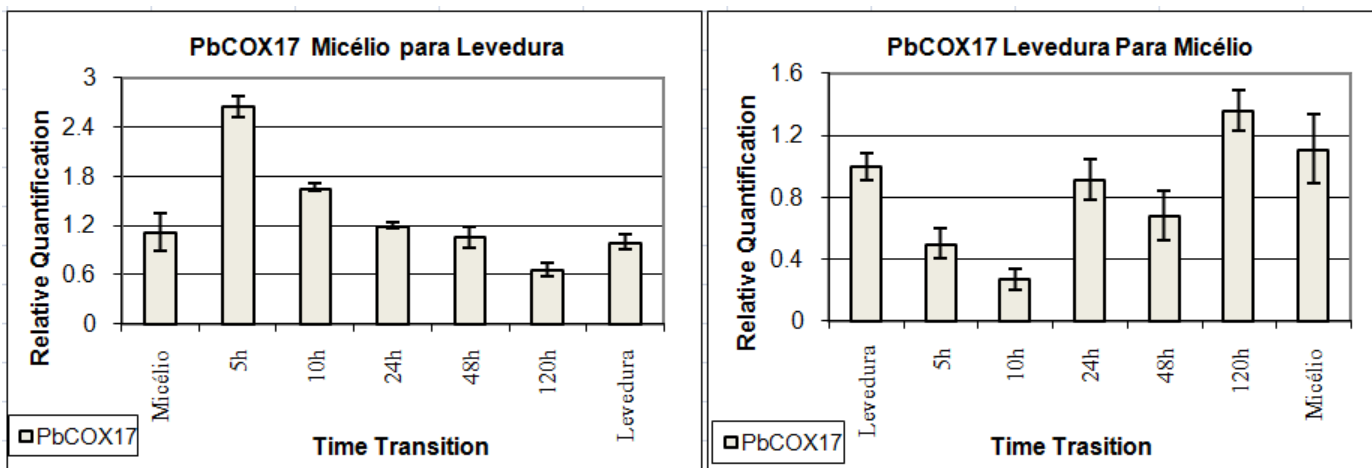

B

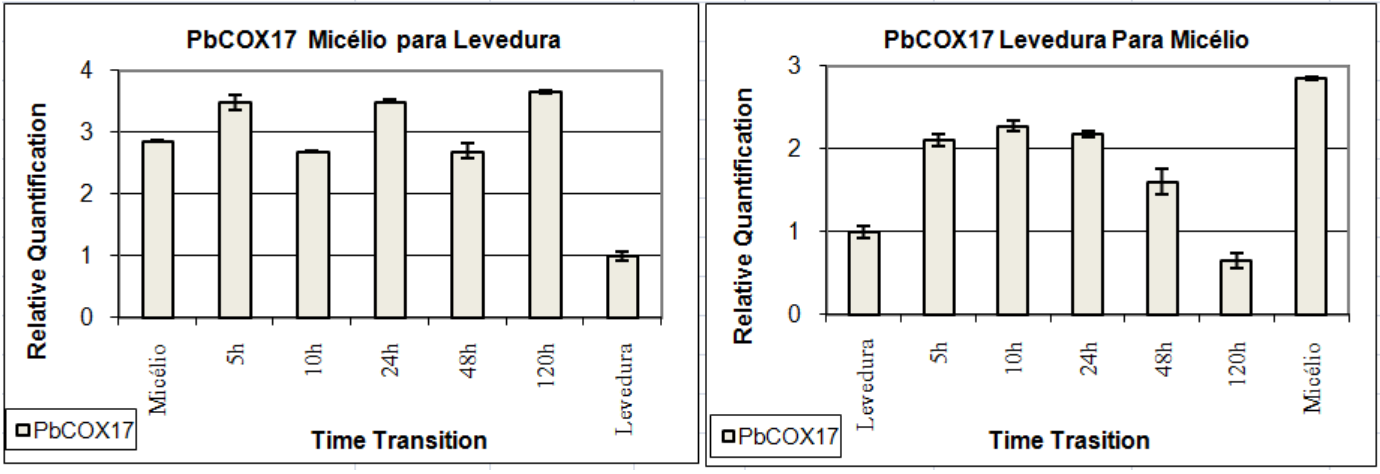

FIGURA 59: Expressão do gene $P b C O X 11$ durante a transição morfológica de $P$. brasiliensis. induzida pela mudança da temperatura. A: Com controle endógeno. B: Sem controle.

A
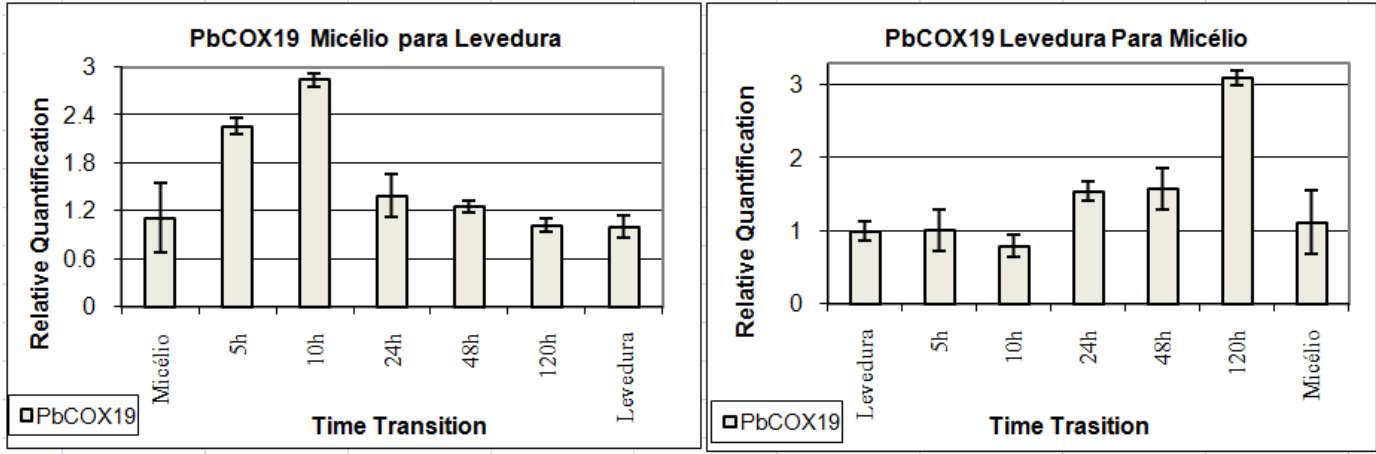

B
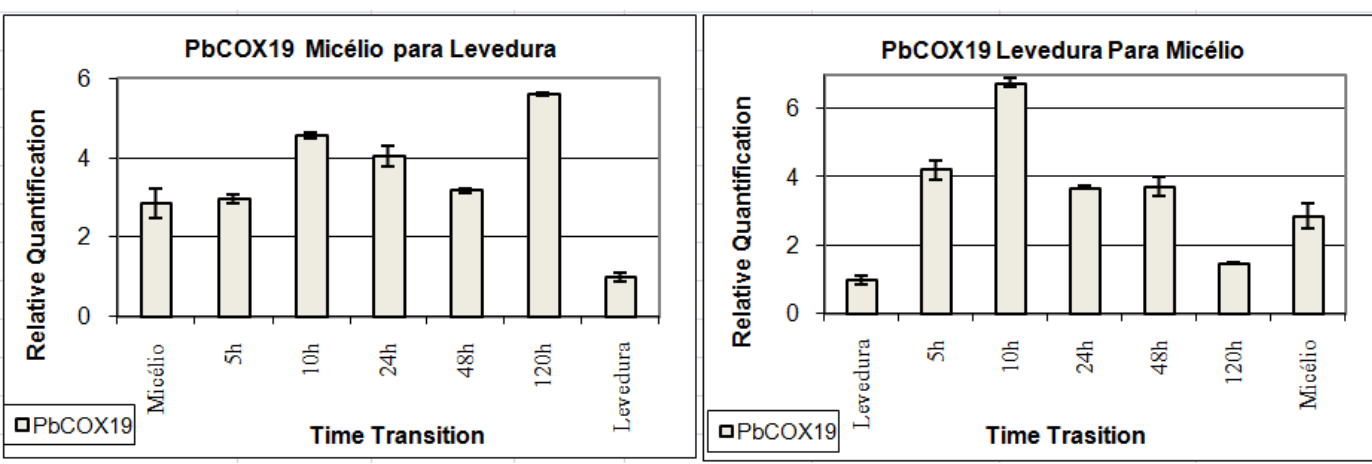

FIGURA 60: Expressão do gene PbCOX19 durante a transição morfológica de $P$. brasiliensis.

induzida pela mudança da temperatura. A: Com controle endógeno. B: Sem controle endógeno. 
A
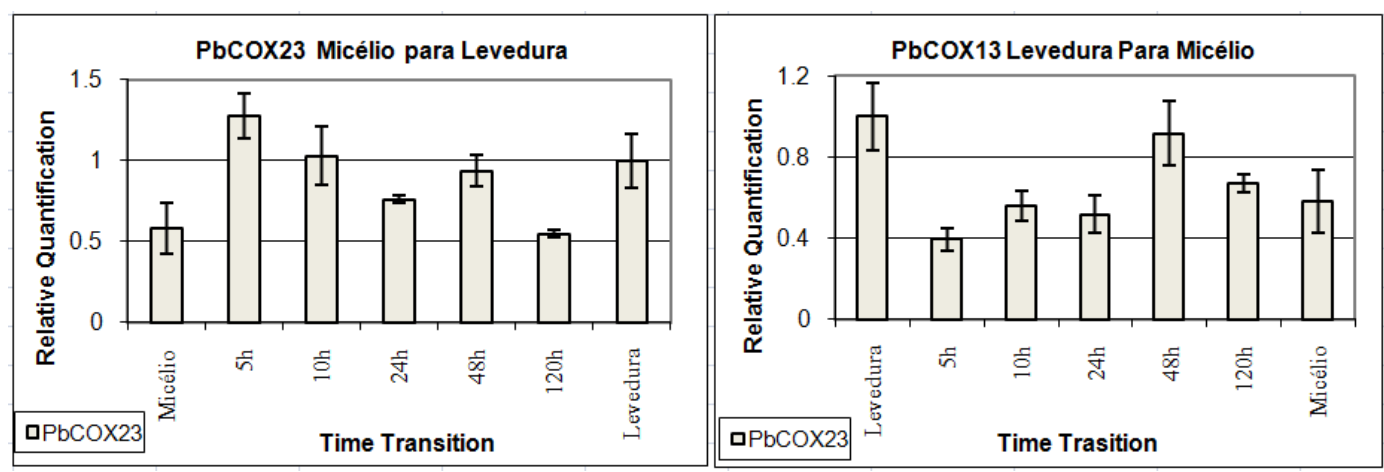

B
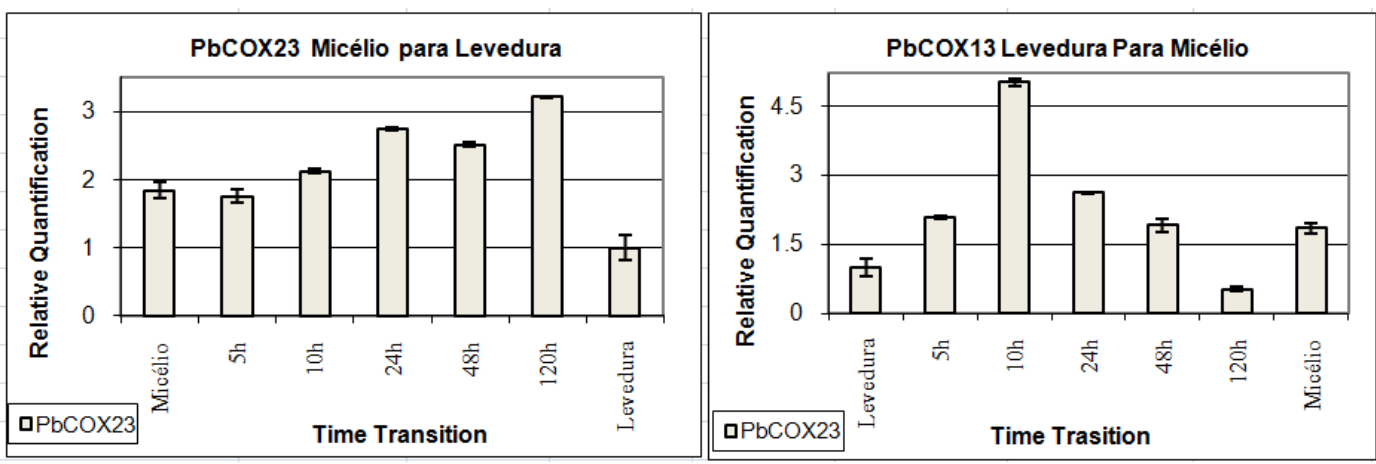

FIGURA 61: Expressão do gene $P b C O X 11$ durante a transição morfológica de $P$. brasiliensis. induzida pela mudança da temperatura. A: Com controle endógeno. B: Sem controle endógeno.

A
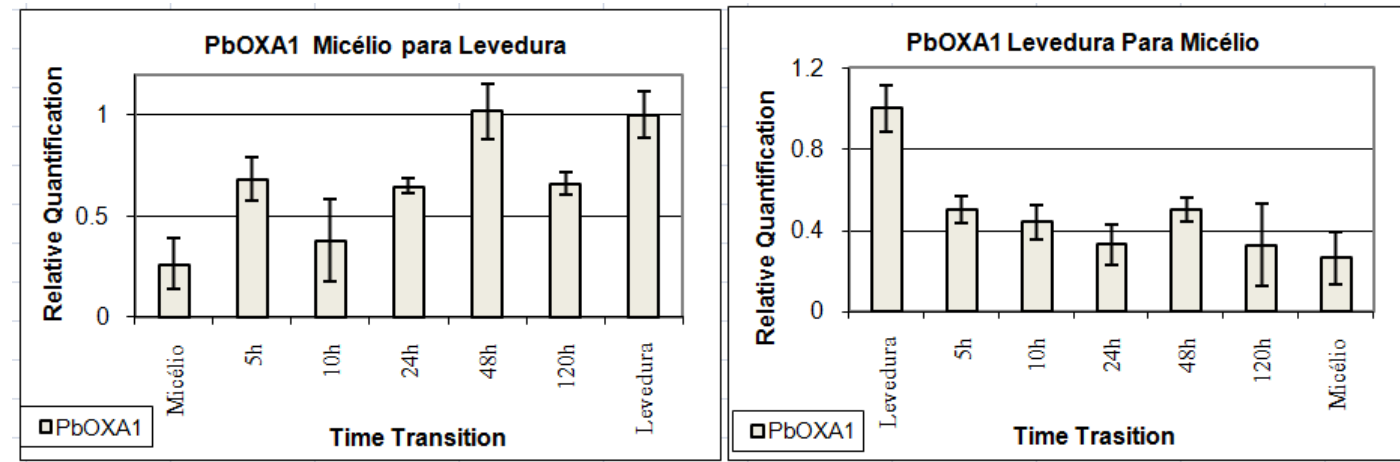

B
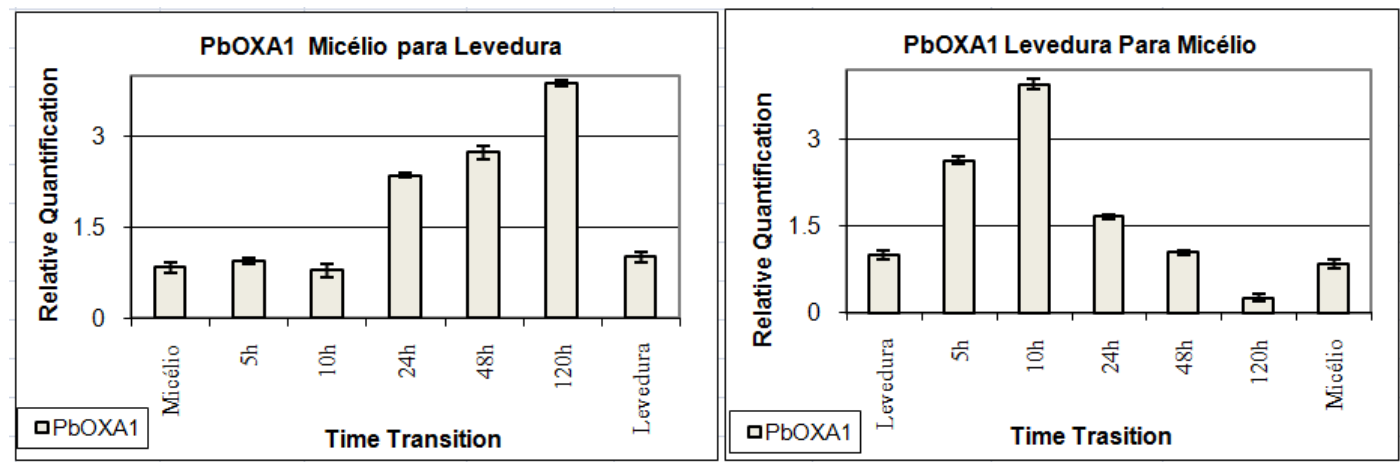

FIGURA 62: Expressão do gene PbOXA1 durante a transição morfológica de $P$. brasiliensis. induzida pela mudança da temperatura. A: Com controle endógeno. B: Sem controle endógeno. 
A

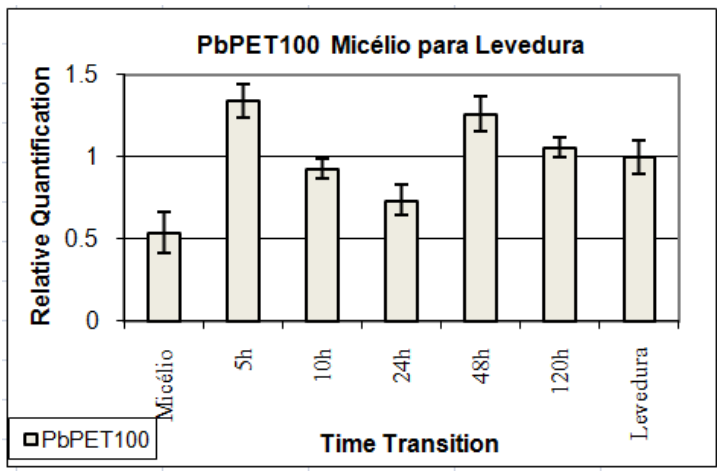

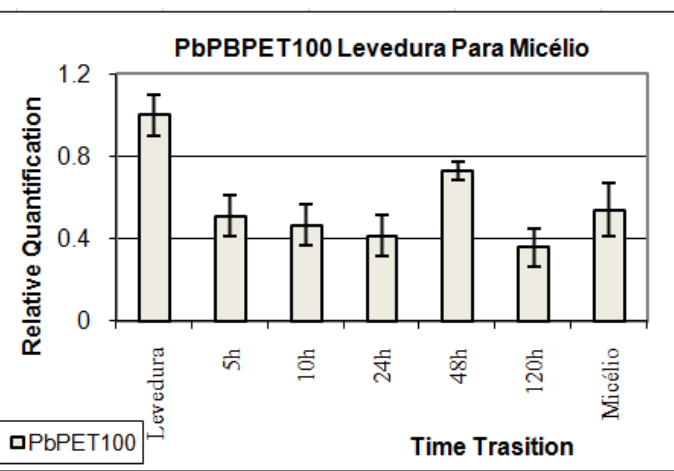

B
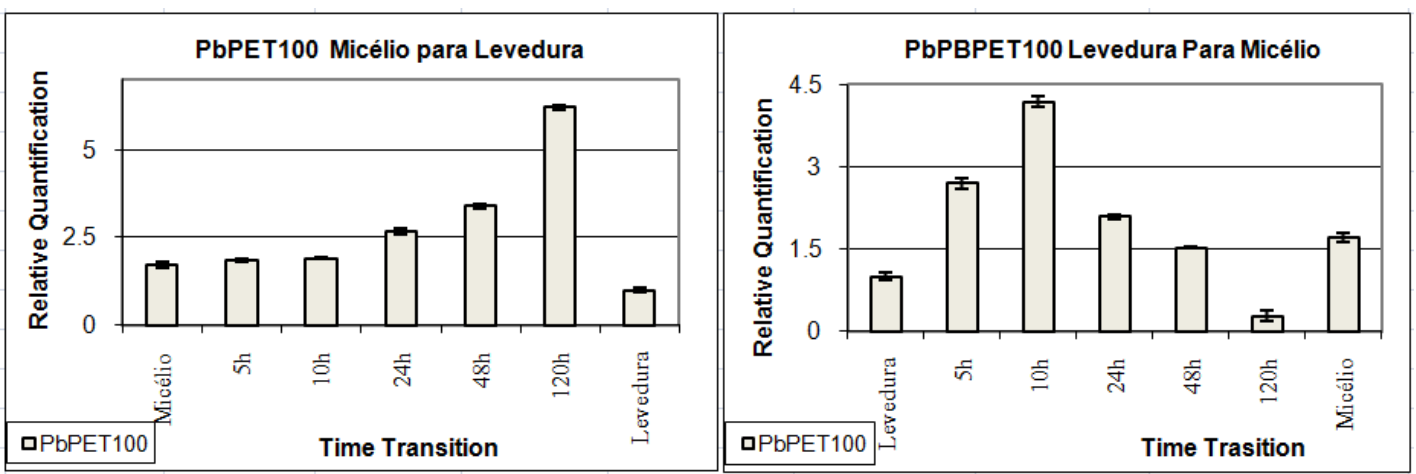

FIGURA 63: Expressão do gene PbPET100 durante a transição morfológica de $P$. brasiliensis. induzida pela mudança da temperatura. A: Com controle endógeno. B: Sem controle endógeno.

A
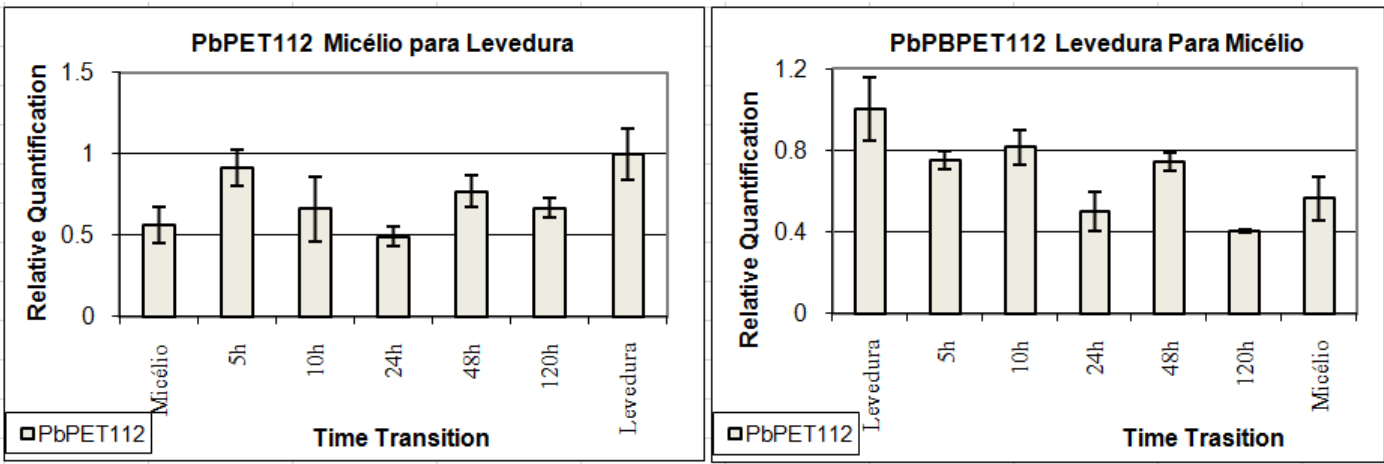

B
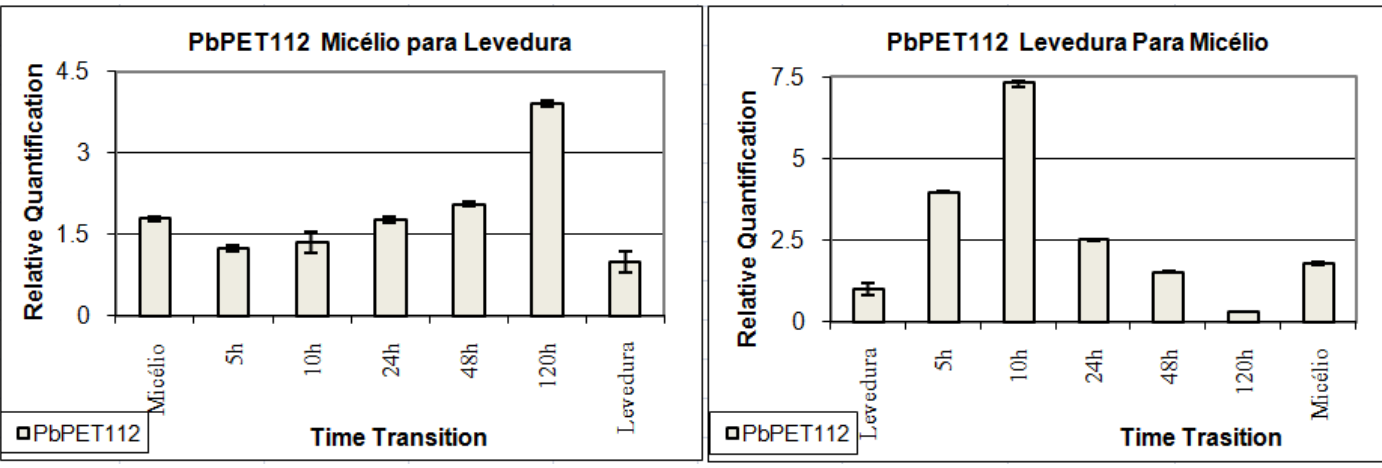

FIGURA 64: Expressão do gene PbPET112 durante a transição morfológica de $P$. brasiliensis. induzida pela mudança da temperatura. A: Com controle endógeno. B: Sem controle endógeno. 
A

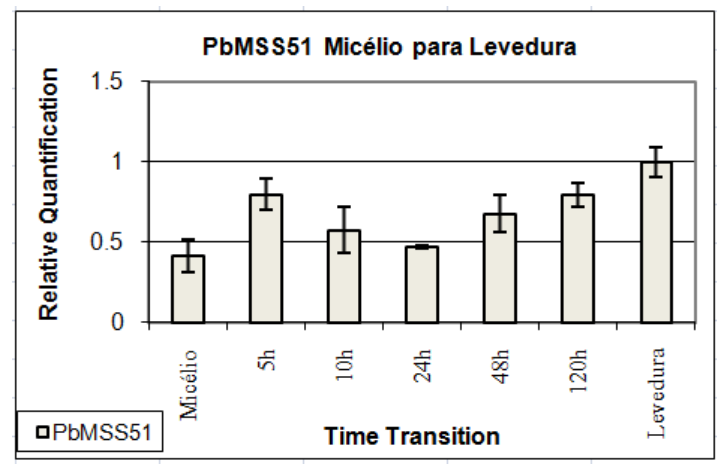

B

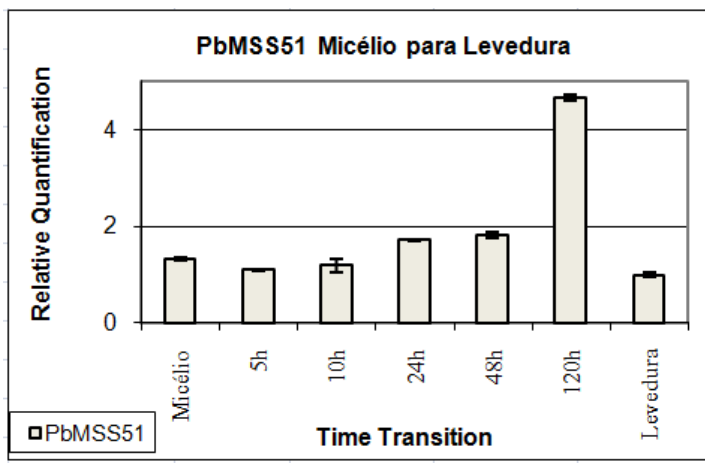

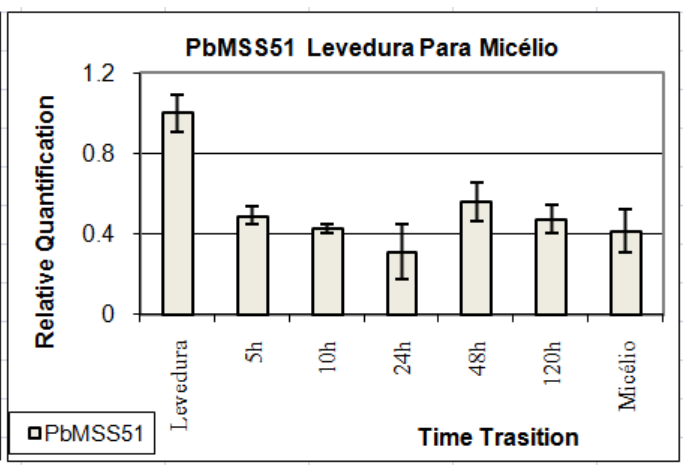

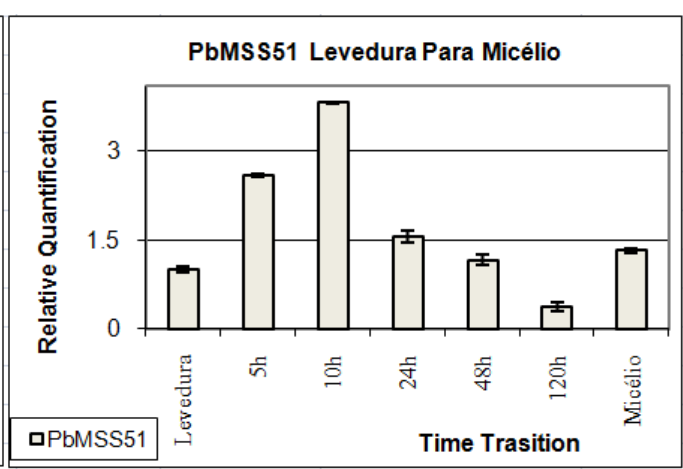

FIGURA 65: Expressão do gene PbMSS51 durante a transição morfológica de $P$. brasiliensis. induzida pela mudança da temperatura. A: Com controle endógeno. B: Sem controle endógeno.

A
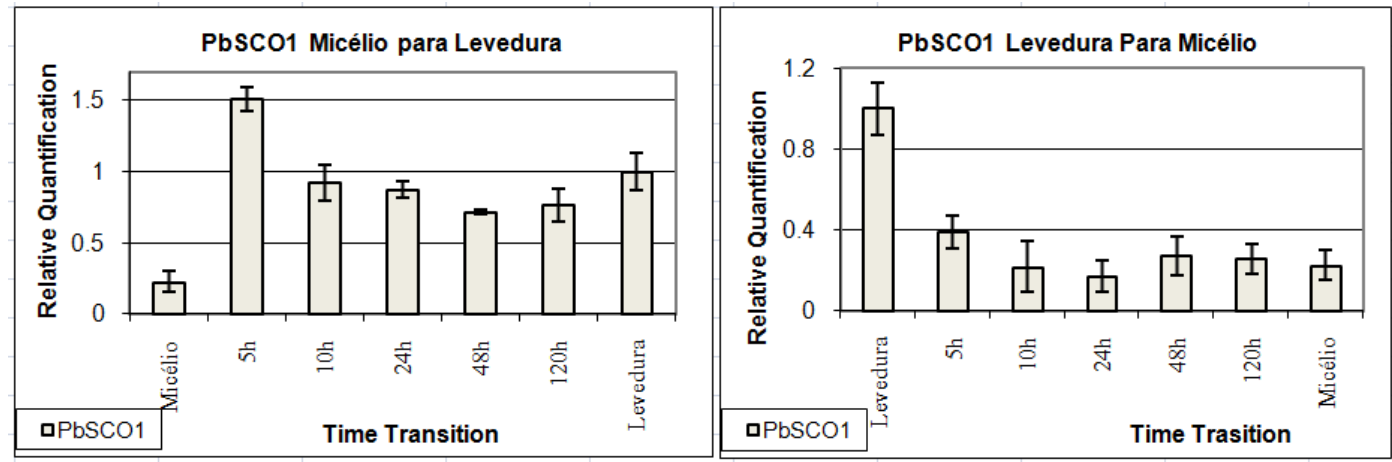

B
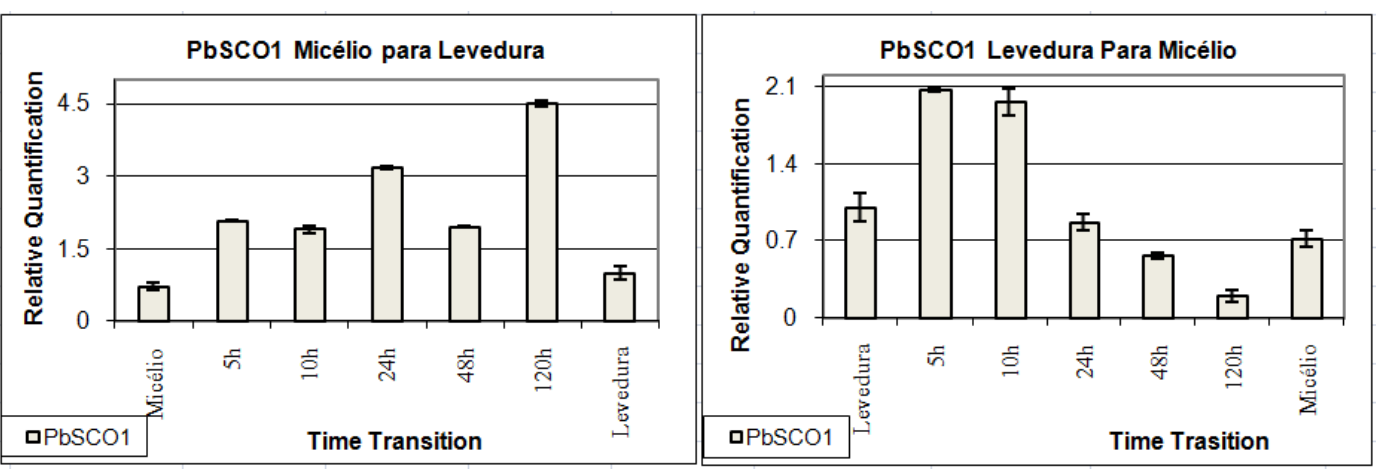

FIGURA 66: Expressão do gene $P b S C O 1$ durante a transição morfológica de $P$. brasiliensis. induzida pela mudança da temperatura. A: Com controle endógeno. B: Sem controle endógeno. 
A

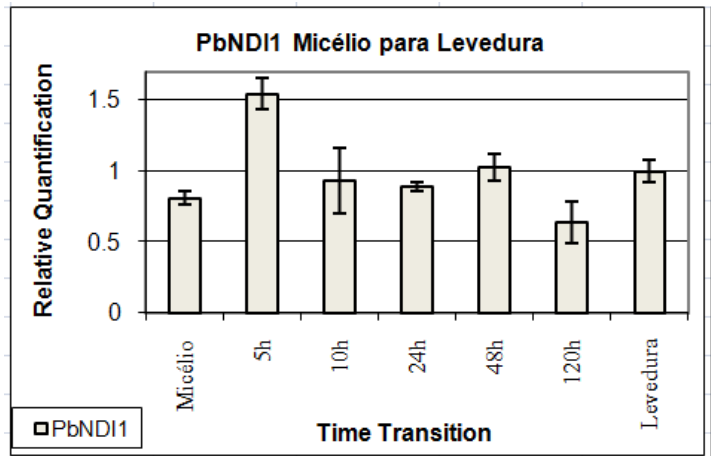

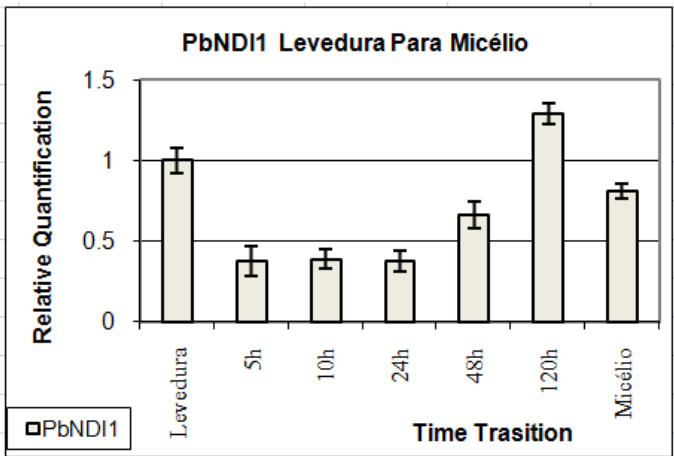

B
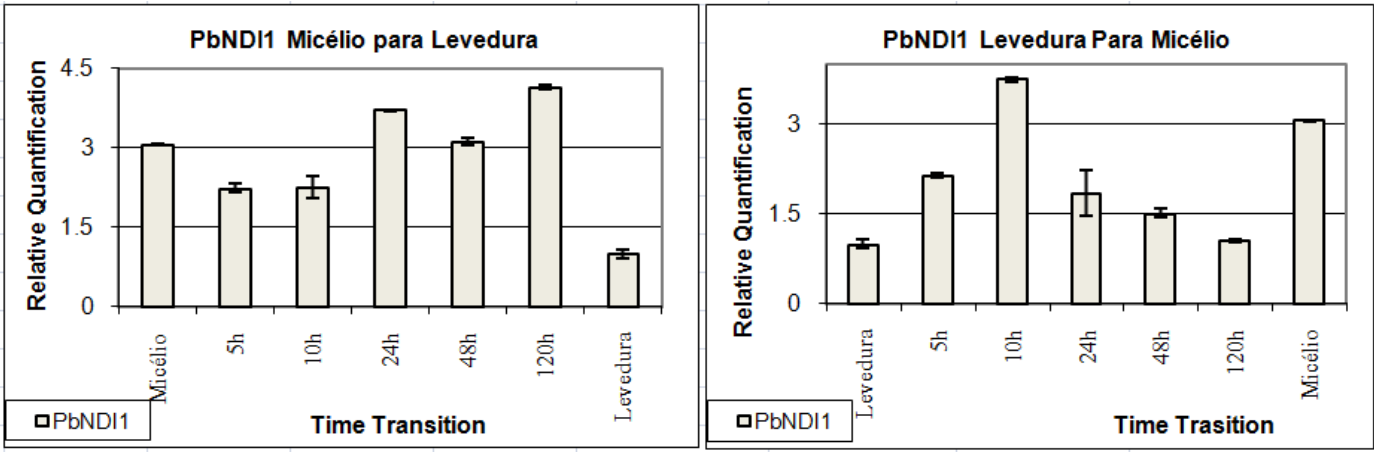

FIGURA 67: Expressão do gene PbNDI1 durante a transição morfológica de $P$. brasiliensis. induzida pela mudança da temperatura. A: Com controle endógeno. B: Sem controle endógeno.

A
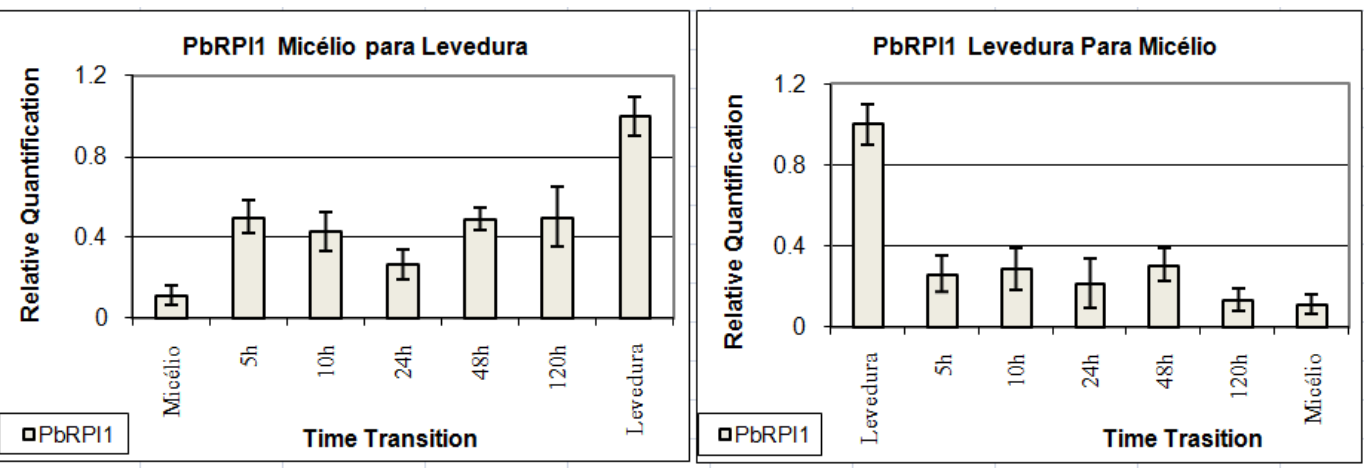

B
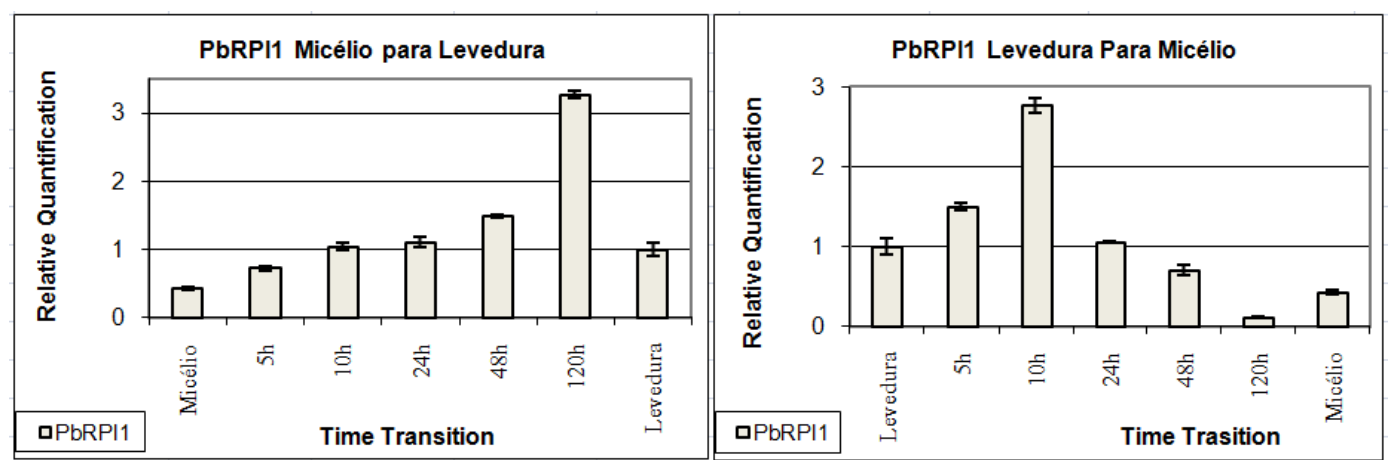

FIGURA 68: Expressão do gene PbRIP1 durante a transição morfológica de $P$. brasiliensis. induzida pela mudança da temperatura. A: Com controle endógeno. B: Sem controle endógeno. 
$\mathbf{F}$

A
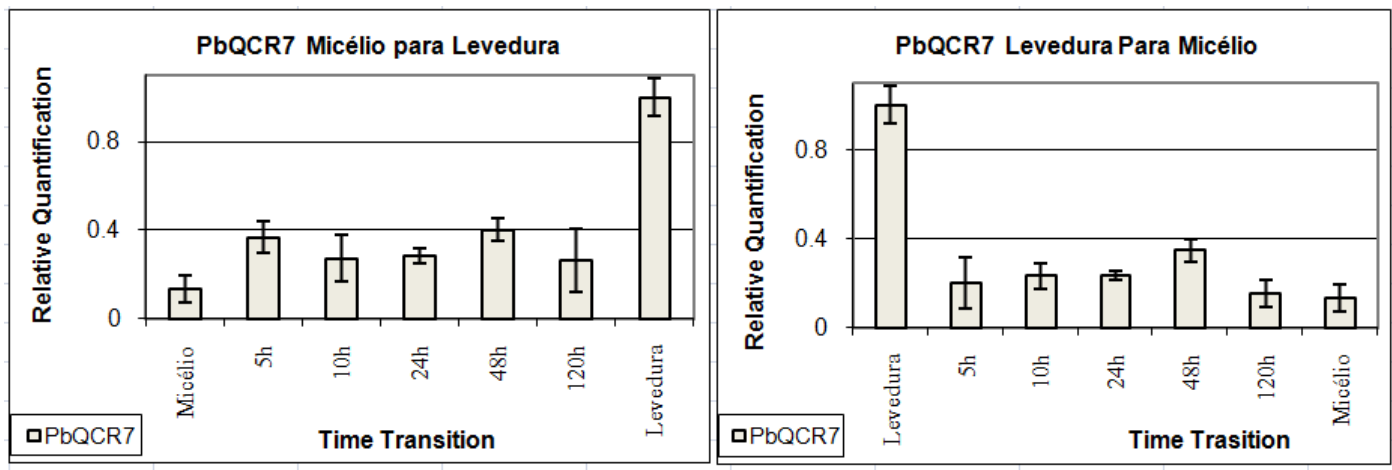

B
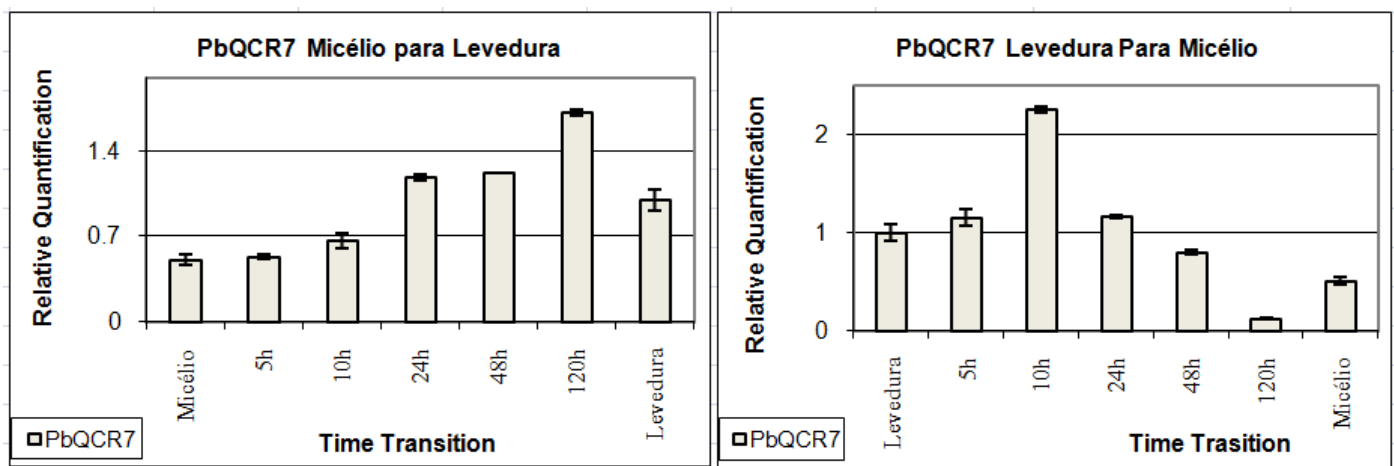

FIGURA 69: Expressão do gene PbQCR7 durante a transição morfológica de $P$. brasiliensis.

induzida pela mudança da temperatura. A: Com controle endógeno. B: Sem controle endógeno.

A

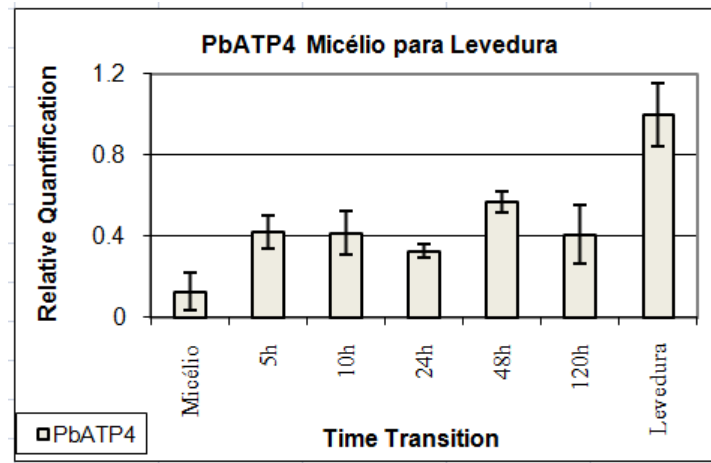

PbATP4 Levedura Para Micélio

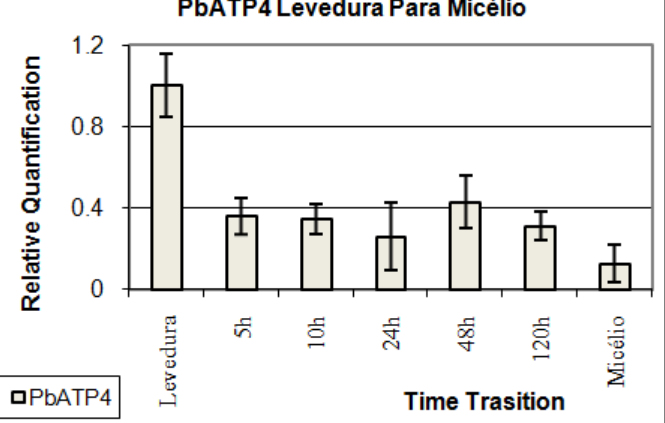

B
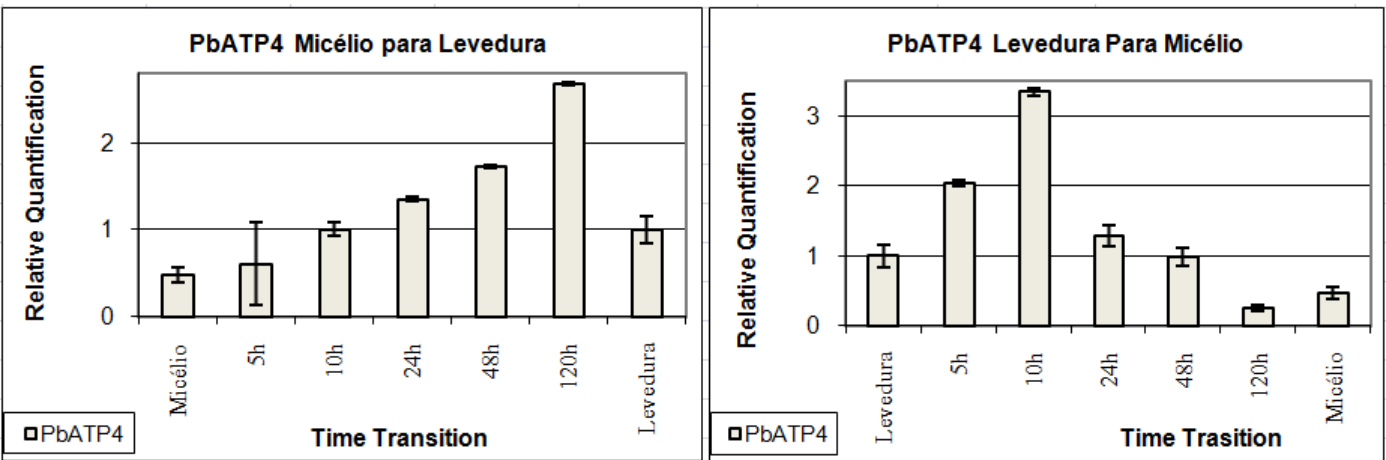

FIGURA 70: Expressão do gene PbATP4 durante a transição morfológica de $P$. brasiliensis. induzida pela mudança da temperatura. A: Com controle endógeno. B: Sem controle endógeno. 
A
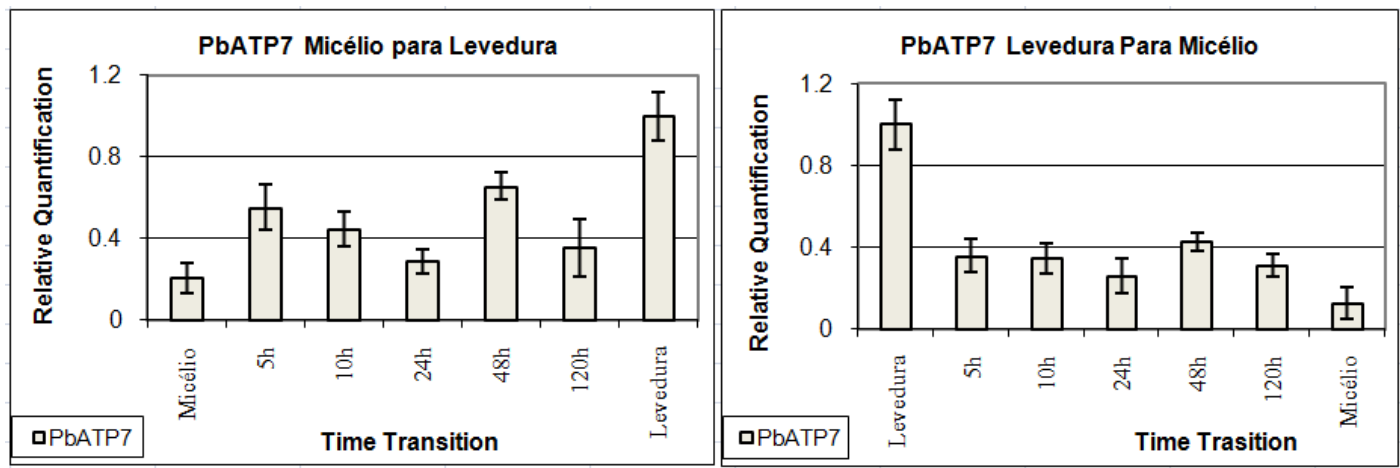

B
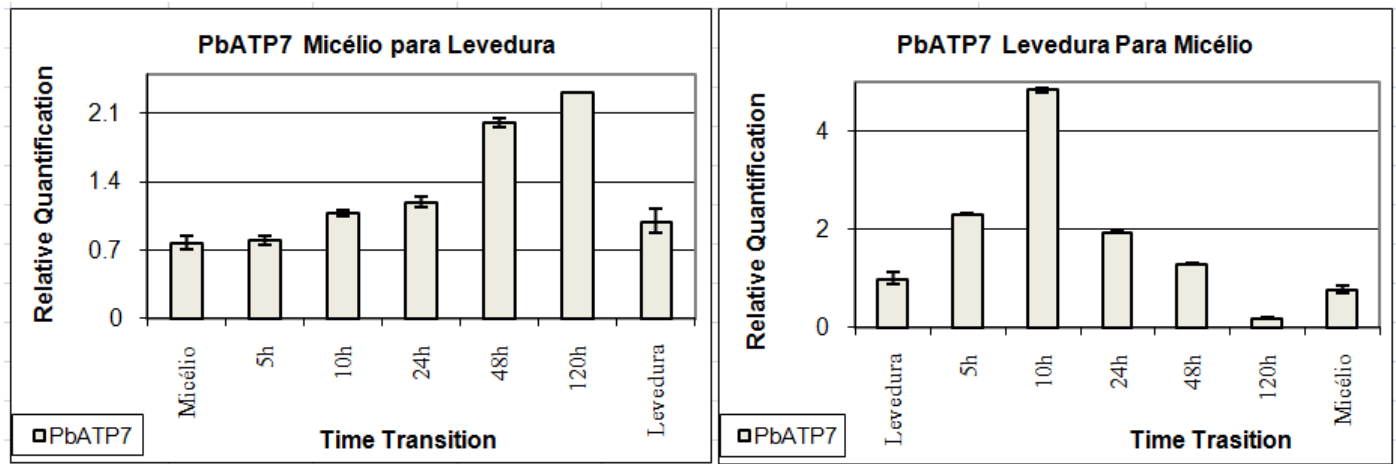

FIGURA 71: Expressão do gene $P b A T P 7$ durante a transição morfológica de $P$. brasiliensis. induzida pela mudança da temperatura. A: Com controle endógeno. B: Sem controle endógeno.
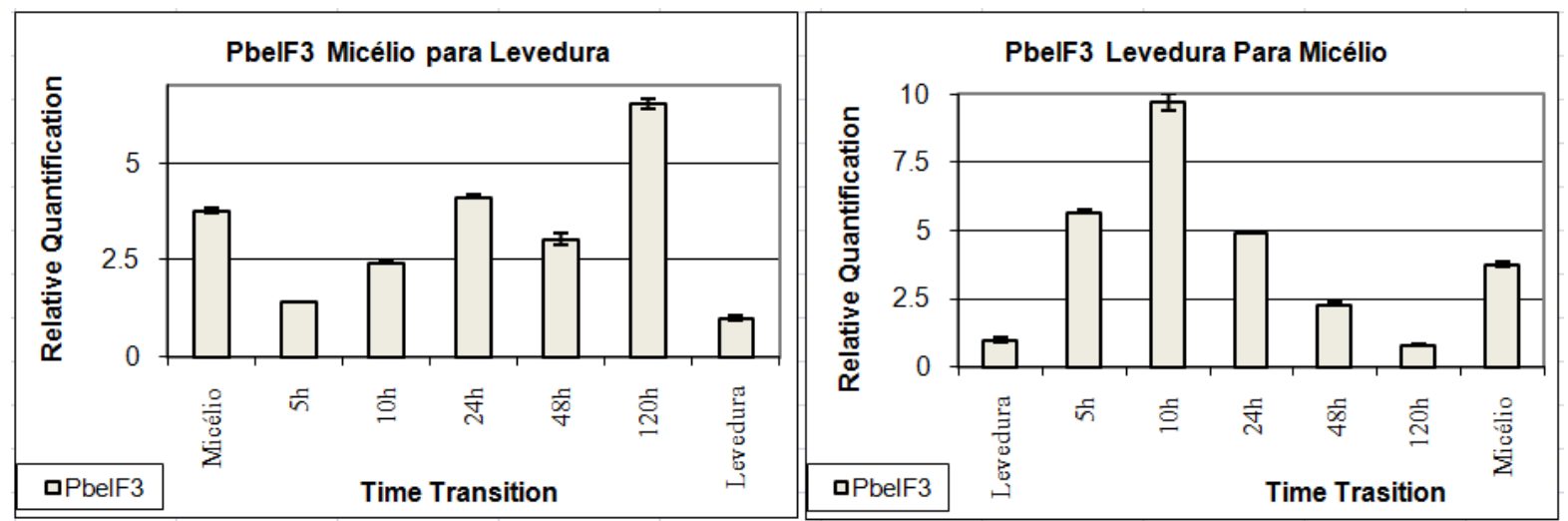

FIGURA 72: Expressão do gene PbeIF3 durante a transição morfológica de $P$. brasiliensis. induzida pela mudança da temperatura. A: Com controle endógeno. B: Sem controle endógeno. 


\subsection{Identificação de Siderófero em Paracoccidioides brasiliensis}

O projeto de seqüenciamento genômico de P.brasilensis foi iniciado em 2004 por Nobrega, M. e colaboradores no LGMG com a construção de várias bibliotécas de RSTs “Random Sequence Tags” ou seqüência aleatória de fragmentos do genoma de P. brasiliensis. Para trabalhar com o genoma deste fungo foi necessário padronizar várias metodologias de extrações e purificação do DNA total, alem da obtenção e purificação dos fragmentos genomicos, montagem das bibliotecas estocagem dos clones, padronização da reação de PCR de seqüenciamento de fragmentos longos bem como no seqüenciamento completo e análise in sílico de clones contendo insertos grandes, ou seja, maiores que 5 kb.

Um clone denominado PbC08 foi inicialmente selecionado para o seqüenciamento completo devido aos resultados obtidos através da análise do padrão de bandeamento por digestão enzimática, que nos indicou a presença de um fragmento genômico maior de 5 kb. O seqüenciamento do inserto total deste clone foi realizado através da técnica de inserção de transposons e subclonagem. Como resultado obtivemos a seqüência de um fragmento genômico de aproximadamente 7.865bp. Uma análise de agrupamento de seqüências contra o banco de dados de seqüências de RSTs de $P$. brasiliensis resultou no agrupamento de mais 1856bp constituindo um fragmento genômico conhecido de 9721bp.

A análise in sílico, por comparação de seqüências contra o banco de dados do GenBank/NCBI, utilizando a ferramenta BLASTx, indica a presença de pelo menos dois genes completos e parte de um terceiro. Um dos genes que estava aparentemente completo no fragmento apresentou similaridade com uma NRPS (Nonribosomal Peptide Synthetase) de Aspergillus fumigatus (GeneID: XP_751389.1). Esta observação foi um dos pontos iniciais de motivação que nos levou a investir na identificação e caracterização de sideróferos bem como a identificação de genes relacionados à biosíntese deste composto quelante de ferro em P.brasiliensis.

Para identificação de sideróferos em P.brasiliensis estamos utilizando o método universal para detecção de sideróferos descrito por Schwyn e Neilands em 1987. O método envolve a utilização de um corante Chrome Azurol S (CAS) complexado com hexadecyltrimethyla mMonium bromide (HDTMA) e ferro este complexo tem coloração azul. A remoção do ferro do complexo CAS-Fe/HDTMA por um siderófero torna o corante laranjado. O corante quando incluído em um meio de cultura pode demonstrar a habilidade de um organismo de remover o ferro do complexo CAS-HDTMA e, portanto, de produzir siderófero através do cultivo direto. Para utilização deste método em $P$. brasiliensis foi 
necessário fazermos a adaptação de um meio de crescimento específico para este organismo, como descrito em material e métodos.

Utilizando este método nos detectamos a produção de siderófero nos cinco isolados (Pb608, Pb18, Pb339, Pb1925 e PbAP) de P.brasiliensis testados. A detecção pode ser observada na figura 73. Uma breve comunicação sobre os resultados já obtidos foram apresentados no "IX Encontro Internacional sobre Paracoccidioidomicose” (Fungal cell biology. Rev. Inst. Med. trop. S. Paulo, 2005, vol.47 suppl.14, p.43-47. ISSN 0036-4665) realizado de 02 a 05 de outubro de 2005 em Águas de Lindóia São Paulo, Brazil.
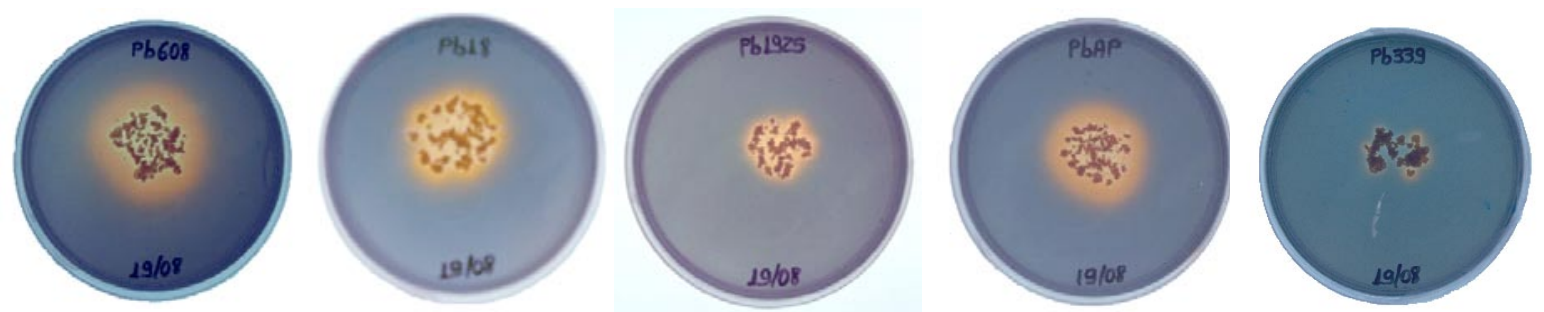

FIGURA 73: Detecção da produção de sideróferos em cinco isolados de $P$. brasiliensis.

(Pb608, Pb18, Pb339, Pb1925 e PbAP). O halo alaranjado é decorrência da retirada do ferro complexado com CAS e HDTMA pelos sideróferos secretados.

Para a caracterização química do tipo (ou dos tipos) de siderófero secretado por $P$. brasiliensis foi necessário padronizar a identificação deste composto em meio líquido.

Foi utilizado um meio de cultura específico para P. brasiliensis mais as sugestões do método universal de Schwyn e Neilands (1987), que indica uma solução de detecção de sideróferos em meio líquido (tanto o meio específico quanto a solução de deteccão estão descrito em “Material e Métodos”).

Após aproximadamente sete dias de crescimento neste meio contendo baixa concentração de ferro as células são recolhidas por centrifugação. O sobrenadante é filtrado e a detecção de sideróferos é feita através da mistura do sobrenadante de cultura com a solução de deteç̧ão (volume/volume). Novamente utilizando o mesmo princípio que no meio sólido, a solução de detecção tem coloração azul, devido ao complexo CAS-Fe/HDTMA e a remoção do ferro do complexo torna o corante laranja. O meio de crescimento controle foi utilizado e como esperado a mudança na coloração da solução só foi observada na mistura contendo o sobrenadante da cultura. O mesmo experimento foi realizado crescendo-se o fungo em meio contendo 0,5M FeCl3 e neste meio em alta concentração de íons Fe a produção de sideróferos não é observada, fato que corrobora os nossos resultados obtidos pelo método universal de Schwyn e Neilands (1987) desde que a síntese de siderófero normalmente é inibida em altas concentrações do metal. 
Embora já tenhamos obtido o sobrenadante concentrado com sideróferos de $P$. brasiliensis e também já termos as amostras parcilmente purificada através de purificação em coluna AMBERLITE XAD16, a análise da estrutura química dos compostos presentes na solução ainda não foram realizadas, devido à falta de infraestrutura disponível para a realização das mesmas até o momento.

\subsubsection{Identificação De Genes Associados À Biossíntese De Siderófero Em Paracoccidioides brasiliensis}

Através de uma busca na literatura sobre as enzimas envolvidos na biosíntese sideróferos em fungos, constatou-se a importância da enzima L-ornithine N5-oxigenase, desde que a reação catalisada por ela (N5-hidroxilação da ornitina) é a primeira etapa da via metabólica de síntese de sideróferos em fungos.

Utilizando a seqüência peptídica da proteína ornithine-N5-oxygenase (gi|67539306) de Aspergillus nidulans contra o branco de dados de ESTs e RSTs de P. brasiliensis, nos identificamos dois clones de ESTs (EST014201 eST014545) e um clone de seqüência genômica RST-VP1-Pb50004-009D06 de P. brasiliensis que apresentam um alto nível de similaridade com esta proteína de A. nidulans.

O inserto do clone RST-VP1-Pb50004-009D06 foi totalmente seqüenciado utilizandose a técnica de inserção de transposons. O fragmento de DNA genômico deste clone consiste de aproximadamente 3151 bp. Quando a seqüência completa do inserto de 3151 bp contido no clone da RST-VP1-Pb50004-009D06 de P. brasiliensis é comparada contra o banco de dados do GenBank/NCBI, utilizando a ferramenta BLASTx, pode-se observar que este fragmento apresenta similaridade com a enzima L-ornithine-N5-oxygenase de vários fungos entretanto a região codificadora não está completa faltando aproximadamente trinta (30) resíduos de aminoácidos da região $\mathrm{N}$-terminal e portanto o fragmento genômico analisado não contêm a seqüência codificadora completa para a L-ornithine-N5-oxygenase .

Nesta análise também podemos observar a presença de possíveis seqüências intrônicas dentro da região correspondendo a região de similaridade com as homólogas (L-ornithine-N5oxygenase). Através da comparação da seqüência do fragmento genômico com a seqüência da EST014545, identificou-se uma seqüência com características do primeiro intron que inicia no nucleotídeo da posição 757 e termina no nucleotídeo 864, deduzindo um provável intron de 107 bp. E outro possível intron que se inicia no nucleotídeo 1364 e termina em 1445, constituindo um intron de 81bp que foi identificado através de análise variadas da seqüência. 
Retirando-se manualmente as duas regiões características de introns do fragmento obtêm-se uma fase aberta de leitura com 489 resíduos de aminoácidos. A análise por BLASTp/NCBI confirma a identidade com a proteína L-ornithine-N5-oxygenase e mostra que esta homóloga de L-ornithine-N5-oxygenase de $P$. brasiliensis apresenta o domínio conservado IucD (Lysine/ornithine N-monooxygenase) característico de enzimas envolvidas na biosíntese de metabólitos secundário, incluindo os sideróferos (Fig. 74).

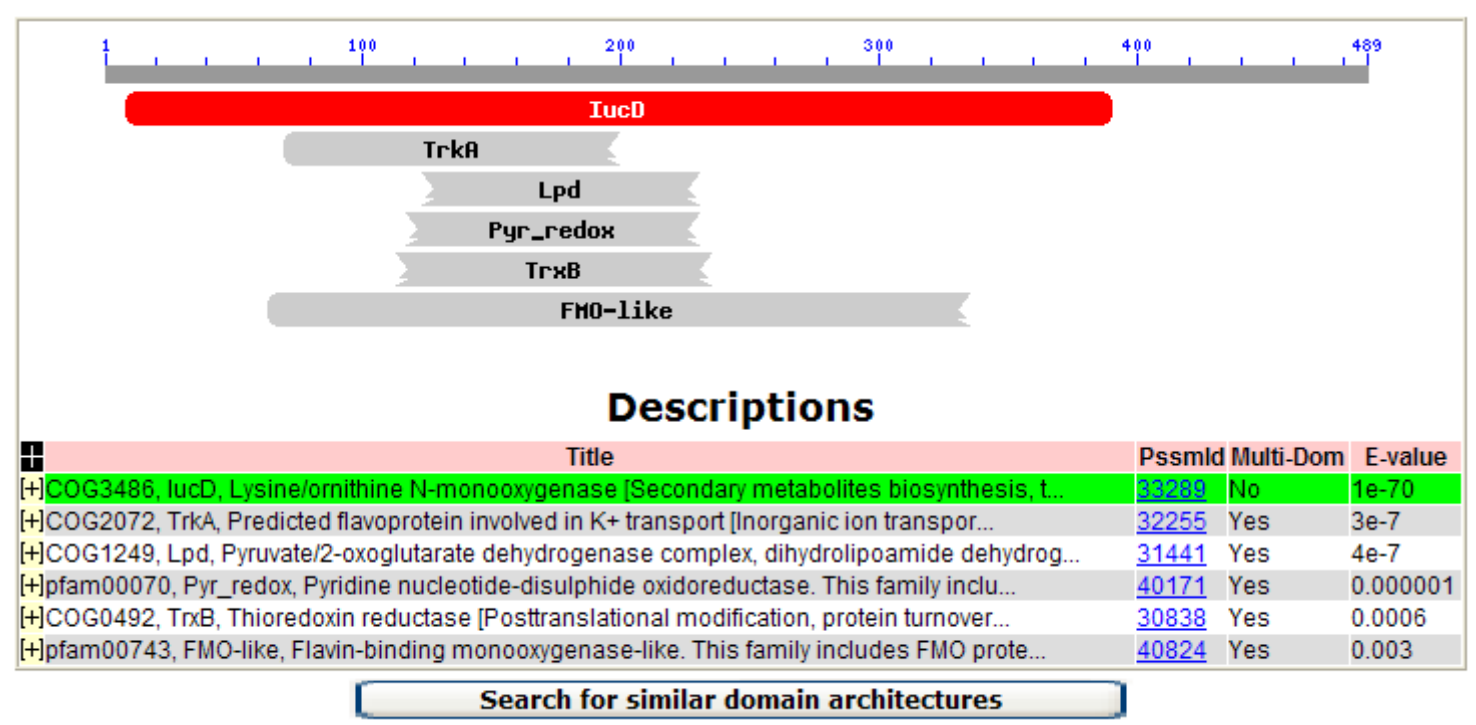

FIGURA 74: Alinhamento por BLASTp da proteína L-ornithine-N5-oxygenase de $P$. brasiliensis. identificada na ORF referente à RST-VP1-Pb50004-009D06. A figura mostra a presença do domínio conservado IucD (Lysine/ornithine N-monooxygenase) característico de enzimas envolvidas na biosíntese de metabólitos secundário, como no caso dos sideróferos. 
As sequências dos dois clones de ESTs (EST014201 eST014545) não foram analisadas entretanto, presença dos mesmos nos bancos de dados de P. brasiliensis, indica que esta proteína realmente é expressa neste fungo e que, portanto, identificando um dos genes envolvidos na biosíntese de sideróferos em $P$. brasiliensis.

Além da seqüência codificadora para a L-ornithine-N5-oxygenase, também pode ser observado a presença de outra seqüência codificadora no fragmento genômico do clone referente a RST-VP1-Pb50004-009D06. Esta segunda seqüência codificadora possui similaridade com a enzima Peroxisomal Dehydratase de vários fungos inclusive de Aspergillus fumigatus e Aspergillus nidulans. Esta enzima contém os domínios conservados HDE_HSD - ("R-hydratase-like hot dog fold of the 17-beta-hydroxysteriod dehydrogenase (HSD), and Hydratase-Dehydrogenase-Epimerase (HDE) proteins; cd03448"). Como os genes que controlam o metabolismo secundário em fungos normalmente estão organizados em conjuntos (“clusters”), as expectativas sugerem que está segunda enzima também possa estar envolvida na via de biosíntese de sideróferos.

A partir da disponibilização da seqüência completa dos genomas dos três isolados de P. brasiliensis foi possível chegar à região codificadora completa do gene da L-ornithine-N5oxygenase e, além disso, confirmar a presença da região codificadora do gene da enzima peroxisomal dehydratase bem como identificar a região codificadora do gene homólogo ao gene mirA, que codifica para um transportador de sideróforos. A confirmação da presença destes genes envolvidos com a via de biosítese de sideróferos nesta região genômica de $P$. brasiliensis fortemente sugerem que realmente esta região representa um cluster de via biosintética de sideróferos neste fungo. 


\section{DISCUSSÃO}

Este trabalho teve como objetivos a identificação e caracterização funcional de genes de $P$. brasiliensis homólogos aos de levedura Saccharomyces cerevisiae envolvidos na biogênese do complexo da citocromo c oxidase mitocondrial, por meio da complementação funcional em mutantes de $S$. cerevisiae. Estudar a estrutura genômica destes genes observando a existência e localização de introns e, analisar a expressão dos mesmos nas fases micelial, leveduriforme e durante a o processo de transição morfológica induzida por temperatura. Além disso, verificar se para este fungo a clonagem direta (a partir de seqüência genômica) permite a expressão funcional na levedura S. cerevisiae.

Neste trabalho estudamos 15 novos genes de $P$. brasiliensis envolvidos na biogênese da haloenzima COX totalizando dezenove genes identificados deste complexo em $P$. brasiliensis. A seqüências obtidas foram depositados no banco de dados do GenBank/NCBI. Como para o fungo $P$. brasiliensis ainda não existe técnica de deleção de genes e nem de transformação padronizados, os genes foram estudados quanto à capacidade de restaurar a atividade da citocromo c oxidase por meio da complementação funcional em mutantes de $S$. cerevisiae. A primeira iniciativa de utilização desse procedimento para o estudo funcional de genes de $P$. brasiliensis foi com o estudo do gene da ornitina descarboxilase (ODC) que complementou com sucesso os transformantes do mutante nulo odc de S. cerevisiae com o gene $P b O D C$ de $P$. brasiliensis (Niño-Vega et al., 2004). Atualmente já existe publicação de vários outros genes estudados com esta técnica, como o gene PbURA3 (Reinoso et al., 2005) e inclusive o gene PbCOX9 que complementou a capacidade respiratória da linhagem mutante cox9 de levedura de S. cerevisiae (Bandeira e Nobrega, 2008).

Dos 15 novos genes estudados de $P$. brasiliensis tivemos sucesso na complementação funcional apenas com os genes PbCOX6, PbCOX17, PbCOX19 e PbOXA1. O gene PbCOX6 é uma subunidade estrutural da COX enquanto que os genes PbCOX17, PbCOX19 estão envolvidos no transporte de íons $\mathrm{Cu}$ para os centros ativos $\mathrm{CuA}$ e $\mathrm{CuB}$ deste complexo. $\mathrm{O}$ gene PbOXA1 codifica para uma insertase que está envolvida na inserção da subunidade Cox2p durante a montagem da holoenzima (He e Fox, 1997; Hell et al., 1997).

O gene PbOXA1 de P.brasiliensis foi capaz de substituir a função de seu homólogo em linhagem mutante da levedura $S$. cerevisiae entretanto quando testamos o recombinante construído com o incerto genômico, contendo dois íntrons, a complementação funcional não ocorreu, provavelmente porquê a maquinaria de "splicing" da levedura não reconheceu os íntrons de $P$. brasiliensis. Este resultado nos leva a concluir que a clonagem direta do genoma 
de $P$. brasiliensis não permite a expressão funcional na levedura $S$. cerevisiae, como é possível com o genoma do fungo C. albicans (Ueda et al., 1997).

Através do alinhamento entre proteínas homólogas de vários organismos para um determinado gene, pode-se observar além das regiões conservadas, ausência ou inserção de pequenos trechos da proteína, ou ainda acréscimo de seqüência nas porções N-terminal e/ou C-terminal provavelmente interfirindo na estrutura tridimensional da proteína impedindo a perfeita interação com suas parceiras. Esta hipótese poderia ser utilizada para argumentar porque não obtivemos sucesso na complementação funcional com vários genes estudados. Entretanto, ainda não fomos capazes de estabelecer nenhum padrão, que poderiam explicar ou prever, através da análise de seqüências, determinado resultado, uma vez que obtivemos complementações funcionais com proteínas apresentando relativamente baixo grau de similaridade de seqüência como no caso do gene PbOXA1.

Quanto às análises da expressão relativa dos genes estudados ( $P b C O X 2, P b C O X 4$, PbCOX5A, PbCOX6, PbCOX8, PbCOX9, PbCOX11, PbCOX12, PbCOX15, PbCOX16, PbCOX17, PbCOX19, PbCOX23, PbPET100, PbPET112, PbOXA1, PbMSS51 e PbSCO1, PbNDI1, PbQCR7, PbRIP1, PbATP4 e PbATP7), durante a transição dimórfica de $P$. brasiliensis tanto de micélio para levedura (M-Y) quanto de levedura para micélio (Y-M), os resultados indicam que estes genes são modulados e que existe expressão ativa das subunidades do complexo da citocromo c oxidase, indicando atividade mitocondrial e respiração durante o processo de transição dimórfica.

Embora exista pequenas diferenças no perfil de expressão entre os vários genes estudados, pode-se observar um padrão bem definido de aumento da expressão deste genes durante todo o período da transição de micélio para levedura. Já na transição de levedura para micélio observamos nas primeiras 10 horas um perfil mais ou menos constante de aumento da expressão seguido de declínio até o termino (120h) da transição.

O aumento da expressão dos genes que participam da biosíntese dos complexos respiratórios é consistente com a maior demanda de energia necessária para que o processo de transição dimórfica ocorra. Enquanto que o declínio da expressão na transição de levedura para micélio após as 10 horas iniciais é consistente com menor atividade de respiração aeróbica observada no fungo na forma de micélio.

A ocorrência de atividade respiratória do fungo $P$. brasiliensis durante o processo de transição é corroborado pelos relatos de Campos et al., 2008, que demonstra a ocorrência de respiração mitocondrial acoplada à fosforilação oxidativa durante o processo de transição do fungo da fase micelial para a forma patogência de levedura e de Martins et al. (2008) de que 
inibidores da cadeia transportadora de elétrons retardaram a transição de micélio para levedura em culturas de $P$. brasiliensis.

Considerando os dados de expressão comparativa das subunidades da citocromo c oxidase mitocondrial de $P$. brasiliensis, o presente resultado sugere que o metabolismo do fungo na fase de levedura pode ser mais aeróbico do que na fase filamentosa. Entretanto, Felipe et al., 2005 através de uma analise do padrão de expressão de genes centrais de metabolismo do fungo tal como os genes das enzimas isocitrato desidrogenase e succinil-CoA sintetase, relacionadas ao ciclo do citrato, sugere um metabolismo mais aeróbico para a forma micelial de $P$. brasiliensis e pelo menos um potencial mais fermentativo na forma de levedura entretanto as observações dos autores se restringiu às formas de micélio e de levedura, não sendo observadas durante o período de transição. Além disso, as análises foram realizadas com um isolado diferente (Pb01) crescendo também em meio diferente do que o utilizado em nossos estudos com o isolado Pb18. Em estudos mais recentes Costa et al., 2007, mostrou através de análise de RT-PCR semi-quantitativo, que apesar de existir maior expressão de genes relacionados ao metabolismo fermentativo na forma de levedura, também pode se observar uma super expressão da subunidade FOF1 da ATP-sintetase nesta forma do fungo.

A interpretação de Felipe e colaboradores também é compartilhada da pelos dados de PCR quantitativo em tempo real da expressão do gene que codifica para a enzima (ADH1) álcool desidrogenase I (Nunes et al., 2005) que está mais expressa na fase de levedura. Em uma tentativa de esclarecer melhor estas observações, também acessamos a expressão do gene da alcool desidrogenase I durante a transição dimorfica de $P$. brasiliensis e, os resultados obtidos confirmam que o gene que codifica esta enzima é super expresso na forma de levedura (dados não mostrados). Entretanto, a expressão do gene da alcool desedrogenase I também foi acessada durante a transiçao de levedura para micélio sendo também detectado considerável expressão deste gene na forma de micélio embora em menor proporção. A disparidade entre os resultados obtidos em relação aos dados de Medoff et al., 1997, também podem ser justificados considerando-se que os experimento de Medoff foram realizados utilizando-se um isolado ( $\mathrm{Pb60}$ ) bem como meios de crescimento diferente do que estamos estudando. A linhagem com a qual este estudo foi realizado, Pb18, é capaz de atingir a completa transição dimórfica no período de aproximadamente cinco (05) dias enquanto que o Pb60, utilizado por Medoff completa a transição em 21 dias. Além disso, como também já observado e relatado por Campos et al., 2008, diferentemente dos experimentos realizados neste trabalho, Medoff e colaboradores realizaram seus experimentos em presença de um inibidor (SHAM) de oxidase alternativa (AOX), uma oxidase terminal relatada somente em 
plantas e fungos que também reduz $\mathrm{O}_{2}$ em $\mathrm{H}_{2} \mathrm{O}$, que como conseqüência reduz o potencial de membrana reduzindo também a fosforilação oxidativa. Portanto, apesar da inibição da AOX por Medoff, de certa forma devesse prevenir a inibição da fosforilaçao oxidativa está não é a real situação do fungo quando em presença do estresse de temperatura, seja durante a invasão do hospedeiro ou em caso de aumento de temperatura do meio de cultura e, portanto, a inibição da AOX pode ser considerada inapropriada para os estudos em questão. Estas observações, portanto, podem ser consideradas quando comparamos os resultados de Medoff et al., 1997 com os obtidos neste estudo. Muito embora, possamos justificar e preciso notar que em nosso estudos estamos inferindo resultados a partir da análise de quantitativa de mRNAs que nem sempre se reflete em efetiva tradução dessa moléculas, além da respiração também pode ser modulada em eventos pós-traducionais.

Ainda pode ser considerado que o aumento da expressão seja causado meramente pela mudança da temperatura em período de adaptação à nova condição ambiental. Dados não mostrados indicam que mesmo quando a transição dimórfica é inibida, verifica-se aumento da expressão dos genes respiratórios quando a temperatura é aumentada de 25 para $37{ }^{\circ} \mathrm{C}$ em níveis relativamente comparáveis aos observados durante a transição.

Considerando todos os relatos sobre os resultados obtidos com estudo de respiração do fungo $P$. brasiliensis, podemos inferir que este fungo utiliza-se tanto de respiração aeróbica como anaeróbica em ambas as formas morfológicas, muito embora, parece haver predominância de respiração aeróbica na forma patogênica de levedura.

Neste trabalho foi analaisado estrutura genomicas dos dezenove (19) genes de $P$. brasiliensis. Os genes PbCOX11, PbPET191, PbSCO1, PbMSS51 e PbOXA1 foram seqüenciados a partir de bibliotecas construídas durante o trabalho ou a partir de amplificação por reação de PCR direta do genoma. O restante dos genes foram estudados a partir da seqüência genomica dos isolados $\mathrm{Pb} 01, \mathrm{~Pb} 03$ e $\mathrm{Pb} 18$, disponibilizados publicamente pelo Fungal Genome Initiative - FGI.

A quantidade de introns nos genes estudados varia de um (01) a sete (07), sendo mais frequente a média de dois (02) a três (03) introns em cada genes. Todos os introns identificados nos genes de $P$. brasiliensis apresentam os domínios característicos de borda intrônica (Reinoso et al., 2005). Em muito dos genes observa-se variações do numero de introns nos diferentes isolados indicando a possibilidade de splicing alternativo.

Para o isolado Pb18 foi possível identificar, com exceção do PbCOX5A, o cromossomo de origem de cada gene. A maior parte dos genes estudados estão localizados no cromossomo 01 (PbCOX6, PbCOX13, PbCOX16, PbCOX17, PbPET191, PbOXA1 e 
PbSCO1), no cromossomo 02 identificamos somente os genes PbCOX8 e PbPET100. O gene PbCOX19 está isolado no cromossomo 03. No cromossomo 04 identificamos os genes PbCOX4, PbCOX15, PbCOX23 e o PbMSS51 e finalmente no cromossomo 05 encontra-se os genes PbCOX9, PbCOX11 e PbCOX12. Embora haja uma concentração de genes no cromossomo 01, não há evidências de formação de “clusters” contendo os genes do complexo da COX.

Apesar de termos interrompido o sequenciamento depois da liberação dos bancos de dados da FGI, identificamos todos os clones selecionados na biblioteca genômica construídas em fosmídeo através dos experimentos de hibridização com as super-membranas. Estes clones estão disponíveis para qualquer estudo especifico que se venha fazer destes genes.

Foi recentemente mostrado que os mutantes cox11 (Banting e Glerum, 2006; Khalimonchuc et al., 2007) e sco1 (Williams et al., 2005) de S. cerevisiae são hipersensíveis ao peróxido de hidrogênio. Sendo estas proteínas ligantes de íons $\mathrm{Cu}$ esta sensibilidade ou função estaria restrita a esta classe de proteínas, desde que outras linhagens mutantes de outros genes envolvidos na biosíntese da COX não apresentaram esta característica (Banting e Glerum, 2006). Os autores sugeriram que a perda da atividade do complexo não constitui em pré-requisito para a sensibilidade ao H2O2. Explorando esta informação verificamos neste trabalho que os mutantes $\Delta \operatorname{cox} 17, \Delta \operatorname{cox} 19$ e $\Delta \operatorname{cox} 23$ de $S$. cerevisiae também apresentam sensibilidades ao peróxido de hidrogênio em diferentes concentrações fortalecendo a relação da resistência ao peróxido de hidrogênio à família das proteínas ligantes de cobre (Banting e Glerum, 2006; Williams et al., 2005). Estudos anteriores (Banting e Glerum, 2006) mostravam que o mutante $\Delta \operatorname{cox} 17$ não apresenta sensibilidade à concentração de $6 \mathrm{mM}$ de $\mathrm{H}_{2} \mathrm{O}_{2}$ entretanto em nosso trabalhos quando submetemos o mutante cox17 ao estresse de altas concentrações (8 mM e $10 \mathrm{mM}$ ) de peróxido observamos melhor a expressão desta sensibilidade.

Portanto quanto a esta função temos quatro genes de $P$. brasiliensis (PbCOX11, PbCOX17, PbCOX19 e PbSCO1) que são capazes de restabelecer a função de seus homólogos nas linhagens mutantes de $S$. cerevisiae. Lembrando que somente com PbCOX17, PbCOX19 obtivemos sucesso quanto a complementação funcional da capacidade respiratória dos mutantes de $S$. cerevisiae.

A parcial funcionalidade do gene COX11 de S. cerevisiae já foi demonstrado ser suficiente para promover a resistência ao peróxido de hidrogênio (Banting e Glerum, 2006) e isto pode explicar o fato de que os genes de P. brasiliensis, PbCOX11 e PbSCO1 embora não sejam funcionalmente equivalentes na função respiratória aos homólogos de $S$. cerevisiae 
sejam equivalentes na função de resistência ao peróxido de hidrogênio. A equivalência em uma das duas possíveis funções destas proteínas de $P$. brasiliensis aos homólogos de $S$. cerevisiae pode, neste caso, validar a caracterização funcional destes dois novos genes de $P$. brasiliensis.

Dos dezenove genes do complexo da COX de P. brasiliensis estudados, quatorze não são funcionalmente equivalentes na função respiratória muito embora conservem alto grau de similaridades na seqüência primária. Portanto, supõe-se que a não equivalência se deva aos arranjos de estrutura terciária dessas proteínas maturadas.

O trabalho aqui exposto apresenta um avanço qualitativo e quantitativo de informações até então desconhecidas sobre a via metabólica de síntese da haloenzima citocromo c oxidase mitocondrial no fungo patogênico P.barsiliensis. O entendimento da atividade deste complexo durante a transição do fungo para a forma patogênica é de grande importância visto que todos os genes analisados têm sua expressão modulada neste processo. Um estudo mais aprofundado, principalmente das subunidades do complexo da COX de $P$. brasiliensis que não são capazes de substituir a função de suas homólogas nos mutantes de $S$. cerevisiae, pode ser uma fonte de descoberta de novos alvos terapêuticos, visto que a função de respiração é vital para todos os eucariotos, inclusive para o fungo e encontrar diferenças significativas entre genes respiratórios de P. brasiliensis e principalmente dos genes humano, é evidentemente importante.

Acrescentamos dados importantes (“clusters”) sobre genes envolvidos em vias metabólicas secundárias (biosíntese de sideróferos). Outro aspecto importante é a nossa abordagem sobre estes quelantes de íons $\mathrm{Fe}^{3+}$ (sideróferos) nestas células demonstrando por ensaios bioquímicos a secreção de sideróferos por este fungo. Destacamos o fato de que estas moléculas são conhecidas na literatura como moléculas que atuam como fatores de virulência em fungos patogênicos. Assim iniciamos também os estudos em P.brasiliensis nesta importante área de moléculas consideradas como uma alternativa de alvo quimioterápico. 


\section{CONCLUSÃo}

Neste trabalho estudamos 15 novos genes de $P$. brasiliensis envolvidos na biogênese da haloenzima citocromo c oxidase mitocondrial, totalizando 19 genes (PbCOX4, PbCOX5A, PbCOX6, PbCOX8, PbCOX9, PbCOX11, PbCOX12, PbCOX13, PbCOX15, PbCOX16, PbCOX17, PbCOX19, PbCOX23, PbMSS51, PbPET100, PbPET112, PbOXA1, PbSCO1) identificados deste complexo em $P$. brasiliensis. As seqüências obtidas foram depositados no banco de dados do GenBank/NCBI.

Trabalhamos também na identificação de genes envolvidos na biosíntese de sideróferos, bem como na verificação da ocorrência de secreção destes compostos em cultura de $P$. brasiliensis.

Dos novos genes estudados tivemos sucesso na complementação funcional heteróloga em mutantes de $S$. cerevisiae com os genes PbCOX6, PbCOX17, PbCOX19 e PbOXA1.

O gene $P b O X A 1$ também foi testado quanto à capacidade de complementação a partir da seqüência do fragmento genômico. Neste ensaio não obtivemos sucesso na complementação indicando que a complementação direta de genes entre estes dois fungos não ocorre.

Neste trabalho foi analisada a estrutura genomica dos dezenove (19) genes de $P$. brasiliensis. Os genes PbCOX11, PbPET191, PbSCO1, PbMSS51 e PbOXA1 foram seqüenciados a partir de bibliotecas construídas durante o trabalho ou a partir de amplificação por reação de PCR direta do genoma. O restante dos genes foi estudado a partir da seqüência genomica dos isolados Pb01, Pb03 e Pb18, disponibilizados publicamente pelo Fungal Genome Initiative - FGI. Todos os genes são analisados apresentam íntrons, como discutidos anteriormente e há evidências de ocorrência de splicing alternativo em alguns destes genes.

A análise da expressão relativa dos genes de $P$. brasiliensis através de reação de PCR em tempo real indicou que estes genes são modulados durante a transição dimórfica de $P$. brasiliensis tanto de micélio para levedura (M-Y) quanto de levedura para micélio (Y-M) e que existe expressão ativa das subunidades do complexo da citocromo c oxidase, indicando atividade respiratória durante o processo de transição dimórfica.

Verificamos neste trabalho que além dos mutantes cox11 (Banting e Glerum, 2006; Khalimonchuc et al., 2007) e sco1 (Williams et al., 2005), os mutantes nulos $\Delta$ cox17, $\Delta$ cox19 e $\Delta$ cox23 de $S$. cerevisiae também apresentam sensibilidade ao peróxido de hidrogênio $\left(\mathrm{H}_{2} \mathrm{O}_{2}\right)$ em altas concentrações fortalecendo a relação da resistência ao peróxido de hidrogênio à família das proteínas ligantes de cobre (Banting e Glerum, 2006). Quatro genes de $P$. 
brasiliensis (PbCOX11, PbCOX17, PbCOX19 e PbSCO1) são capazes de substituir a função de seus homólogos em linhagens mutantes de S. cerevisiae restabelecendo a resistência ao peróxido. Lembrando que destes, obtivemos sucesso quanto a complementação funcional da capacidade respiratória somente com os genes PbCOX17 e PbCOX19. 


\section{REFERÊNCIAS*}

Aggeler R, Capaldi RA. Yeast cytochrome c oxidase subunit VII is essential for assembly of an active enzyme. Cloning, sequencing, and characterization of the nuclear-encoded gene. $\mathrm{J}$ Biol Chem.1990; 265:16389-93.

Altamura N, Capitanio N, Bonnefoy N, Papa S, Dujardin G. The Saccharomyces cerevisiae OXA1 gene is required for the correct assembly of cytochrome c oxidase and oligomycinsensitive ATP synthase. FEBS Lett. 1996; 382(1-2):111-5.

Amaravadi R, Glerum DM, Tzagoloff A. Isolation of a cDNA encoding the human homolog of COX17, a yeast gene essential for mitochondrial copper recruitment. Hum Genet. 1997; 99(3):329-33.

Antonicka H, Mattman A, Carlson CG, Glerum DM, Hoffbuhr KC, Leary SC, Kennaway NG, Shoubridge EA. Mutations in COX15 produce a defect in the mitochondrial heme biosynthetic pathway, causing early-onset fatal hypertrophic cardiomyopathy. Am J Hum Genet. 2003; 72(1):101-14.

Arnesano F, Balatri E, Banci L, Bertini I, Winge DR. Folding studies of Cox17 reveal an important interplay of cysteine oxidation and copper binding. Structure. 2005; 13(5):713-22.

Attallah CV, Welchen E, Pujol C, Bonnard G, Gonzalez DH. Characterization of Arabidopsis thaliana genes encoding functional homologues of the yeast metal chaperone Cox19p, involved in cytochrome c oxidase biogenesis. Plant Mol Biol. 2007; 65(3):343-55.

Ausubel F, Brent R, Kingston ER, Moore DD, Seidman JG, Smith JA, Sthuhl K. Short Protocols in Molecular Biology. Madison: Jonh Wiley, 1995.

Balandin T, Castresana C. AtCOX17, an Arabidopsis homolog of the yeast copper chaperone COX17. Plant Physiol. 2002; 129(4):1852-7.

Bandeira SCB, Nóbrega MP. Characterization of Paracoccidioides brasiliensis COX9, COX12, and COX16 respiratory genes. Mycol Res. 2008; 112:1414-20.

Banting GS, Glerum DM. Mutational analysis of the Saccharomyces cerevisiae cytochrome c oxidase assembly protein Cox11p. Eukaryot Cell. 2006; 5(3):568-78.

\footnotetext{
* De acordo com:

International Committee of Medical Journal Editors. Uniform requirements for manuscripts submitted to Biomedical Journal: sample references. Available from: http://www.icmje.org [2007 May 22].
} 
Barrientos A, Barros MH, Valnot I, Rotig A, Rustin P, Tzagoloff A. Cytochrome oxidase in health and disease.Gene. 2002; 286(1):53-63.

Barrientos A, Zambrano A, Tzagoloff A. Mss51p and Cox14p jointly regulate mitochondrial Cox1p expression in Saccharomyces cerevisiae. EMBO J. 2004; 23(17):3472-82.

Barrientos A, Korr D, Tzagoloff A. Shy1p is necessary for full expression of mitochondrial COX1 in the yeast model of Leigh's syndrome. EMBO J. 2002; 21(1-2):43-52.

Barros MH, Carlson CG, Glerum DM, Tzagoloff A. Involvement of mitochondrial ferredoxin and Cox15p in hydroxylation of heme O. FEBS Lett. 2001; 492(1-2):133-8.

Barros MH, Nobrega FG, Tzagoloff A. Mitochondrial ferredoxin is required for heme A synthesis in Saccharomyces cerevisiae. J Biol Chem. 2002; 277(12):9997-10002.

Barros MH, Johnson A, Tzagoloff A. COX23, a homologue of COX17, is required for cytochrome oxidase assembly. J Biol Chem. 2004; 279(30):31943-7.

Barros MH, Myers AM, Van Driesche S, Tzagoloff A. COX24 codes for a mitochondrial protein required for processing of the COX1 transcript. J Biol Chem. 2006; 281(6):3743-51.

Bauer M, Behrens M, Esser K, Michaelis G, Pratje E. PET1402, a nuclear gene required for proteolytic processing of cytochrome oxidase subunit 2 in yeast. Mol Gen Genet. 1994; 245(3):272-8.

Beauvoit B, Bunoust O, Guerin B; Rigoulet M. ATP-regulation of cytochrome oxidase in yeast mitochondria: role of subunit VIa. Eur J Biochem. 1999; 263(1):118-27.

Beers J, Glerum DM, Tzagoloff A. Purification, characterization, and localization of yeast Cox17p, a mitochondrial copper shuttle. J Biol Chem. 1997; 272(52):33191-6.

Beers J, Glerum DM, Tzagoloff A. Purification and characterization of yeast Sco1p, a mitochondrial copper protein. J Biol Chem. 2002; 277(25):22185-90.

Bonnefoy N, Chalvet F, Hamel P, Slonimski PP, Dujardin G. OXA1, a Saccharomyces cerevisiae nuclear gene whose sequence is conserved from prokaryotes to eukaryotes controls cytochrome oxidase biogenesis. J Mol Biol. 1994a; 239(2):201-12. 
Bonnefoy N, Kermorgant M, Groudinsky O, Minet M, Slonimski PP, Dujardin G. Cloning of a human gene involved in cytochrome oxidase assembly by functional complementation of an oxa1- mutation in Saccharomyces cerevisiae. Proc Natl Acad Sci USA. 1994b; 91(25):1197882.

Borges-Walmsley MI, Chen D, Shu X, Walmsley AR. The pathobiology of Paracoccidioides brasiliensis. Trends Micobiol. 2002; 10:80-7.

Brendel M, Henriques JA. The pso mutants of Saccharomyces cerevisiae comprise two groups: one deficient in DNA repair and another with altered mutagen metabolism. Mutat Res. 2001; 489:79-96.

Broadley SA, Demlow CM, Fox TD. Peripheral mitochondrial inner membrane protein, Mss2p, required for export of the mitochondrially coded Cox2p C tail in Saccharomyces cerevisiae. Mol Cell Biol. 2001; 22:7663-72.

Brummer E, Castaneda E, Restrepo A. Paracoccidioidomycosis: an update. Clin Microbiol Rev. 1993; 6(2):89-117. Review.

Bryan AC, Rodeheffer MS, Wearn CM, Shadel GS. Sls1p is a membrane-bound regulator of transcription-coupled processes involved in Saccharomyces cerevisiae mitochondrial gene expression. Genetics. 2002; 60(1):75-82.

Buchwald P, Krummeck G, Rodel G. I mMunological identification of yeast SCO1 protein as a component of the inner mitochondrial membrane. Mol Gen Genet. 1991; 229(3):413-20.

Campos CB, Di Benedette JP, Morais FV, Ovalle R, Nobrega MP. Evidence for the role of calcineurin in morphogenesis and calcium homeostasis during mycelium-to-yeast dimorphism of Paracoccidioides brasiliensis. Eukaryot Cell. 2008; 7(10):1856-64.

Cano MI, Cisalpino PS, Galindo I, Ramirez JL, Mortara RA, Da Silveira JF. Eletrophoretic Karyotypes and genome sizing of the pathogenic fungus Paracoccidioides brasiliensis. J Clin Microbiol. 1998; 36(3):742-7.

Cardoso MA, Tambor JH, Nobrega FG. The mitochondrial genome from the thermal dimorphic fungus Paracoccidioides brasiliensis. Yeast. 2007; 24(7):607-16.

Carlson CG, Barrientos A, Tzagoloff A, Glerum DM. COX16 encodes a novel protein required for the assembly of cytochrome oxidase in Saccharomyces cerevisiae. J Biol Chem. 2003; 278(6):3770-5. 
Carr HS, Carr HS, George GN, Winge DR. Yeast Cox11, a protein essential for cytochrome c oxidase assembly, is a Cu(I)-binding protein. J Biol Chem. 2002; 277(34):31237-42.

Carr HS, Maxfield AB, Horng YC, Winge DR. Functional Analysis of the Domains in Cox11. J Biol Chem. 2005; 280:22664-9.

Celebi N, Yi L, Facey SJ, Kuhn A, Dalbey RE. Membrane biogenesis of subunit II of cytochrome bo oxidase: contrasting requirements for insertion of N-terminal and C-terminal domains. J Mol Biol. 2006; 357(5):1428-36.

Cisalpino OS, Puccia R, Yamauchi LM, Cano MIN, Silveira JF, Travassos LR. Cloning, characterization, and epitope expression of the major diagnostic antigen of Paracoccidioides brasiliensis. J Biol Chem. 1996; 271:4553-60.

Church C, Chapon C, Poyton RO. Cloning and characterization of PET100, a gene required for the assembly of yeast cytochrome c oxidase. J Biol Chem. 1996; 271(31):18499-507.

Church C, Goehring B, Forsha D, Wazny P, Poyton RO. A role for Pet100p in the assembly of yeast cytochrome c oxidase: interaction with a subassembly that accumulates in a pet100 mutant. J Biol Chem. 2005; 280(3):1854-63.

Coyne HJ 3rd, Ciofi-Baffoni S, Banci L, Bertini I, Zhang L, George GN, Winge DR. The characterization and role of zinc binding in yeast Cox4. J Biol Chem. 2007; 282(12):8926-34.

Colby G, Wu M, Tzagoloff A. MTO1 codes for a mitochondrial protein required for respiration in paromomycin-resistant mutants of Saccharomyces cerevisiae. J Biol Chem. 1998; 273(43):27945-52.

Conrad-Webb H, Perlman PS, Zhu H, Butow RA. The nuclear SUV3-1 mutation affects a variety of post-transcriptional processes in yeast mitochondria. Nucleic Acids Res. 1990; 18(6):1369-76.

Costa M, Borges CL, Bailão AM, Meirelles GV, Mendonça YA, Dantas SF, de Faria FP, Felipe MS, Molinari-Madlum EE, Mendes-Giannini MJ, Fiuza RB, Martins WS, Pereira M, Soares CM. Transcriptome profiling of Paracoccidioides brasiliensis yeast-phase cells recovered from infected mice brings new insights into fungal response upon host interaction. Microbiology. 2007; 153:4194-207.

Costanzo MC, Fox TD. Specific translational activation by nuclear gene products occurs in the 5' untranslated leader of a yeast mitochondrial mRNA. Proc Natl Acad Sci USA. 1988; 85(8):2677-81. 
Costanzo MC, Seaver EC, Fox TD. At least two nuclear gene products are specifically required for translation of a single mitochondrial mRNA. EMBO J. 1986a; 5:3637.

Costanzo MC, Mueller PP, Strick CA, Fox TD. Primary structure of wild-type and mutant alleles of the PET494 gene of Saccharomyces cerevisiae, Mol Gen Genet. 1986b; 202(2):294301.

Costanzo MC, Seaver EC, Fox TD. The PET54 gene of Saccharomyces cerevisiae: Characterization of a nuclear gene encoding a mitochondrial translational activator and subcellular localization of its product. Genetics. 1989;122(2):297-305.

Decoster E, Simon M, Hatat D, Faye G. The MSS51 gene product is required for the translation of the COX1 mRNA in yeast mitochondria. Mol Gen Genet. 1990; 224(1):111-8.

Decoster E, Vassal A, FayE G. MSS1, a nuclear-encoded mitochondrial GTPase involved in the expression of COX1 subunit of cytochrome c oxidase. J Mol Biol. 1993; 232(1):79-88.

Dowhan W, Bibus CR, Schatz G. The citoplasmically-made subunit IV is necessary for assembly of cytochrome c oxidase in yeast. EMBO J. 1985; 4:179.

du Plessis DJ, Nouwen N, Driessen AJ. Subunit a of cytochrome o oxidase requires both YidC and SecYEG for membrane insertion. J Biol Chem. 2006; 281(18):12248-52.

Eisendle M, Oberegger $\mathrm{H}$, Zadra I, Haas $\mathrm{H}$. The siderophore system is essential for viability of Aspergillus nidulans: functional analysis of two genes encoding l-ornithine $\mathrm{N}$ 5monooxygenase (sidA) and a non-ribosomal peptide synthetase (sidC). Mol Microbiol. 2003; 49(2):359-75.

Ernest JF. Regulation of dimorfism in Candida Albicans In: Ernest JF, Schimdyt A, editors. Dimorphism in human pathogenic and pathogenic yeast. Basel: Karger; 2000. p. 98-111.

Errington J, Appleby L, Daniel RA, Goodfellow H, Partridge SR, Yudkin MD. Structure and function of the spoIIIJ gene of Bacillus subtilis: a vegetatively expressed gene that is essential for sigma $G$ activity at an intermediate stage of sporulation. J Gen Microbiol. 1992; 138(12):2609-18.

Faye G, Simon M. Analysis of a yeast nuclear gene involved in the maturation of mitochondrial pre-messenger RNA of the cytochrome oxidase subunit I. Ce1l. 1983; 32(1):77-87. 
Feitosa Ldos S, Cisalpino PS, dos Santos MR, Mortara RA, Barros TF, Morais FV, Puccia R, da Silveira JF, de Camargo ZP. Chromosomal polymorphism, syntenic relationships, and ploidy in the pathogenic fungus Paracoccidioides brasiliensis. Fungal Genet Biol. 2003; 39(1):60-9.

Felipe MS, Andrade RV, Arraes Fb, Nicola AM, Maranhao AQ, Torres FA, Silva-Pereira I, Pocas-Fonseca MJ, Campos EG, Moraes LM, Andrade PA, Tavares AH, Silva SS, Kyaw CM, Souza DP, Network P, Pereira M, Jesuino RS, Andrade EV, Parente JA, Oliveira GS, Barbosa MS, Martins Nf, Fachin Al, Cardoso Rs, Passos Ga, Almeida Nf, Emilia M T Walter M, Soares CM, Jose A, Carvalho M, Brigido MM. Transcriptional profiles of the human pathogenic fungus Paracoccidioides brasiliensis in mycelium and yeast cells. J Biol Chem. 2005; 280(26):24706-14.

Felipe MSS, Andrade RV, Petrofeza SS, Maranhão AQ, Torres FAG, Albuquerque P, Arraes FBM, Arruda M, Azevedo MO, Baptista AJ, Bataus LAM, Borges CL, Campos EG, Cruz MR, Daher BS, Dantas A, Ferreira MASV, Ghil GV, Jesuino RSA, Kyaw CM, Leitão L, Martins CRL. Moraes MP, Neves EO, Nicola AM, Alves ES, Parente JA, Pereira M, PoçasFonseca MJ, Resende R, Ribeiro BM, Saldanha RR, Santos SC, Silva-Pereira I, Silva MAS, Silveira E, Simões IC, Soares RBA, Souza DP, De-Souza MT, Andrade EV, Xavier MAS, Veiga HP, Venancio EJ, Carvalho MJA, Oliveira AG, Inoue MK, Almeida NF, Walter MEMT, Soares CMA, Brýgido MM. Transcriptome Characterization Of The Dimorphic And Pathogenic Fungus Paracoccidioides Brasiliensis By Est Analysis. Yeast. 2003; 20:263-71.

Forsha D, Church C, Wazny P, Poyton RO. Structure and function of Pet100p, a molecular chaperone required for the assembly of cytochrome $c$ oxidase in Saccharomyces cerevisiae. Biochem Soc Trans. 2001; 29:436-41.

Goldani LZ, Sugar AM. Paracoccidioidomycosis and AIDS: an overview. Clin Infect Dis. 1995; 21:1275-81.

Goldman GH, Dos Reis Marques E, Duarte Ribeiro DC, De Souza Bernardes LA, Quiapin AC, Vitorelli PM, Savoldi M, Semighini CP, De Oliveira RC, Nunes LR, Travassos LR, Puccia R, Batista WL, Ferreira LE, Moreira JC, Bogossian AP, Tekaia F, Nobrega MP, Nobrega FG, Goldman MH. Expressed sequence tag analysis of the human pathogen Paracoccidioides brasiliensis yeast phase: identification of putative homologues of Candida albicans virulence and pathogenicity genes. Eukaryot Cell. 2003; 2(1):34-48.

Glerum DM, Shtanko A, Tzagoloff A.Characterization of COX17, a yeast gene involved in copper metabolism and assembly of cytochrome oxidase. J Biol Chem. 1996a; 271(24):14504-9.

Glerum DM, Shtanko A, Tzagoloff A. SCO1 and SCO2 act as high copy suppressors of a mitochondrial copper recruitment defect in Saccharomyces cerevisiae. J Biol Chem. 1996b; 271(34):20531-5. 
Glerum DM, Tzagoloff A. Isolation of a human cDNA for heme A:farnesyltransferase by functional complementation of a yeast cox10 mutant. Proc Natl Acad Sci USA. 1994; 91(18):8452-6.

Glerum DM, Muroff I, Jin C, Tzagoloff A. COX15 codes for a mitochondrial protein essential for the assembly of yeast cytochrome oxidase. J Biol Chem. 1997; 272(30):19088-94.

Glerum DM, Koerner TJ, Tzagoloff A. Cloning and characterization of COX14, whose product is required for assembly of yeast cytochrome oxidase. J Biol Chem. 1995; 270(26):15585-90.

Grant CM, Maciver FH, Dawes IW. Mitochondrial function is required for resistance to oxidative stress in the yeast Saccharomyces cerevisiae. FEBS Lett. 1997; 410(2-3):219-222.

Grant SGN, Jessee J, Bloom FR, Hanahan D. Differential Plasmid Rescue From Transgenic Mouse DNAs Into Escherichia coli Methylation-Restriction Mutants. Proc Natl Acad Sci USA. 1990; 87:4645-9.

Green-Willms NS, Butler CA, Dunstan HM, Fox TD. Pet111p, an inner membrane-bound translational activator that limits expression of the Saccharomyces cerevisiae mitochondrial gene COX2. J Biol Chem. 2001; 276(9):6392-7.

Guerinot ML. Microbial iron transport. Annu Rev Microbiol. 1994; 48:743-72.

Haas H. Molecular genetics of fungal siderophore biosynthesis and uptake: the role of siderophores in iron uptake and storage. Appl Microbiol Biotechnol. 2003; 62(4):316-30.

Halliwell B, Gutteridge JM. Oxygen toxicity, oxygen radicals, transition metals and disease. Biochem J. 1984; 219(1):1-14.

Hamel P, Sakamoto W, Wintz H, Dujardin G. Functional complementation of an oxa1- yeast mutation identifies an Arabidopsis thaliana cDNA involved in the assembly of respiratory complexes. Plant J. 1997; 12(6):1319-27.

Hatefi Y. The mitochondrial electron transport and oxidative phosphorylation system Annu Rev Biochem. 1985; 54:1015-69.

He S, Fox TD. Membrane translocation of mitochondrially coded Cox2p: distinct requirements for export of $\mathrm{N}$ and $\mathrm{C}$ termini and dependence on the conserved protein Oxa1p. Mol Biol Cell. 1997; 8:1449-60. 
He S, Fox TD. Mutations Affecting a Yeast Mitochondrial Inner Membrane Protein, Pnt1p, Block Export of a Mitochondrially Synthesized Fusion Protein from the Matrix. Mol Cell Biol. 1999; 19(10):6598-6607.

Hell K, Herrmann J, Pratje E. Neupert W, Stuart RA. Oxa1p mediates the export of the Nand C-termini of $p$ CoxII from the mitochondrial matrix to the intermembrane space. FEBS Lett. 1997; 418:367-70.

Hell K, Tzagoloff A, Neupert W, Stuart RA. Identification of Cox20p, a novel protein involved in the maturation and assembly of cytochrome oxidase subunit 2. J Biol Chem. 2000; 275(7):4571-8.

Herbert CJ, Dujardin B, Labouesse M, Slonimski PP. Divergence of the mitochondria1 leucyl tRNA synthetase genes in two closely related yeasts Saccharomyces cerevisiae and Saccharomyces douglasii: A paradigm of incipient evolution. Mol Gen Genet. 1988a; 213:297.

Herbert CJ, Labouesse M, Dujardin B, Slonimski PP. The NAM2 proteins from S. cerevisiae and $S$. douglasii are mitochondrialleucyl-tRNA synthetases, and are involved in mRNA splicing. EMBO J. 1988b; 7:473.

Herrmann JM, Funes S. Biogenesis of cytochrome oxidase-sophisticated assembly lines in the mitochondrial inner membrane.Gene. 2005; 354:43-52.

Herrmann JM, Neupert W, Stuart RA. Insertion into the mitochondrial inner membrane of a polytopic protein, the nuclear-encoded Oxa1p. EMBO J. 1997; 6(9):2217-26.

Heymann P, Gerads M, Schaller M, Dromer F, Winkelmann G, Ernst JF. The siderophore iron transporter of Candida albicans (Sit1p/Arn1p) mediates uptake of ferrichrome-type siderophores and is required for epithelial invasion. Infect Immun. 2002; 70(9):5246-55.

Hiser L, Di Valentin M, Hamer AG, Hosler JP. Cox11p is required for stable formation of the $\mathrm{Cu}(\mathrm{B})$ and magnesium centers of cytochrome c oxidase. J Biol Chem. 2000; 275(1):619-23.

Hissen AH, Chow JM, Pinto LJ, Moore MM. Survival of Aspergillus fumigatus in serum involves removal of iron from transferrin: the role of siderophores. Infect Immun. 2004; 72(3):1402-8. 
Horng YC, Cobine PA, Maxfield AB, Carr HS, Winge DR. Specific copper transfer from the Cox17 metallochaperone to both Sco1 and Cox11 in the assembly of yeast cytochrome c oxidase. J Biol Chem. 2004; 279(34):35334-40.

Hu CJ, Bai C, Zheng XD, Wang YM, Wang Y. Characterization and functional analysis of the siderophore-iron transporter CaArn1p in Candida albicans. J Biol Chem. 2002; 277(34):30598-605.

Jaksch M, Ogilvie I, Yao J, Kortenhaus G, Bresser HG, Gerbitz KD. Shoubridge EA. Mutations in SCO2 are associated with a distinct form of hypertrophic cardiomyopathy and cytochrome c oxidase deficiency. Hum Mol Genet. 2000; 9:795-801.

Johnson $\mathrm{CH}$, McEwen JE. Mitochondrial protein synthesis is not required for efficient excision of intron aI5 beta from COX1 pre-mRNA in Saccharomyces cerevisiae. Mol Gen Genet. 1997; 256(1):88-91.

Khalimonchuk O, Ostermann K, Rödel G. Evidence for the association of yeast mitochondrial ribosomes with Cox11p, a protein required for the $\mathrm{Cu}(\mathrm{B})$ site formation of cytochrome $\mathrm{C}$ oxidase. Curr Genet. 2005; 47(4):223-33.

Khalimonchuk O, Bird A, Winge DR. Evidence for a Pro-oxidant Intermediate in the Assembly of Cytochrome Oxidase. J Biol Chem. 2007; 282(24):17442-9.

Kim SI, Stange-Thomann N, Martins O, Hong KW, Soll D, Fox TD. A nuclear genetic lesion affecting Saccharomyces cerevisiae mitochondrial translation is complemented by a homologous Bacillus gene. J Bacteriol. 1997; 179(17):5625-7.

Kleinkauf H, Von Dohren H. A nonribosomal system of peptide biosynthesis. Eur J Biochem. 1996; 236(2):335-1.

Koemer TJ, Hill J, Tzagoloff A. Cloning and characterization of the yeast nuclear gene for subunit 5 of cytochrome oxidase. J Biol Chem. 1985; 260:9513-15.

Krummeck G, Rodel G. Yeast SCO1 protein is required for a post-translational step in the accumulation of mitochondrial cytochrome c oxidase subunits I and II. Curr Genet. 1990; 18:13-15.

Lacaz CS, Porto E, Martins JEC. Paracoccidioidomicose. Micologia Medica. 8. ed. São Paulo: Sarvier; 1991. p. 248-97. 
Lamarche AEP, Abate MI, Chant SHP, Trumpower BL. Isolation and characterization of COXI2, the nuclear gene for a previously unrecognized subunit of Saccharomyces cerevisiae cytochrome c oxidase. J Biol Chem. 1992; 267:22473-80.

Leary SC, Cobine PA, Kaufman BA, Guercin GH, Mattman A, Palaty J, Lockitch G, Winge DR, Rustin P, Horvath R, Shoubridge EA. The human cytochrome c oxidase assembly factors SCO1 and SCO2 have regulatory roles in the maintenance of cellular copper homeostasis. Cell Metab. 2007; 5(1):9-20. Erratum in: Cell Metab. 2007; 5(5):403.

Leary SC, Kaufman BA, Pellecchia G, Guercin GH, Mattman A, Jaksch M, Shoubridge EA. Human SCO1 and SCO2 have independent, cooperative functions in copper delivery to cytochrome c oxidase. Hum Mol Genet. 2004; 13:1839-48.

Leong SA, Winkelmann G. Molecular biology of iron transport in fungi. Met Ions Biol Syst. 1998; 35:147-86.

Lesuisse E, Simon-Casteras M, Labbe P. Siderophore-mediated iron uptake in Saccharomyces cerevisiae: the SIT1 gene encodes a ferrioxamine B permease that belongs to the major facilitator superfamily. Microbiology. 1998; 144(Pt 12):3455-62.

Livak KJ, Schmittgen TD. Analysis of relative gene expression data using real-time quantitative PCR and the $2^{-{ }^{\text {DDCt }}}$ method. Methods. 2001; 25:402-8.

Lode A, Paret C, Rodel G. Molecular characterization of Saccharomyces cerevisiae Sco2p reveals a high degree of redundancy with Sco1p. Yeast. 2002; 19(11):909-22.

Loose DS, Prince Stover E, Restrepo A, Stevens DA, Feldman D. Estradiol binds to a receptor-like cytosol binding protein and initiates a biological response in Paracoccidioides brasiliensis. Med Sci. 1983; 80:7659-63.

Ludewig G, Staben C. Characterization of the PNT1 pentamidine resistance gene of Saccharomyces cerevisiae. Antimicrob Agents Chemother. 1994; 38(12):2850-6.

Maarse AC, Van Loon AP, Riezman H, Gregor I, Schatz G, Grivell LA. Subunit IV of yeast cytochrome c oxidase: cloning and nucleotide sequencing of the gene and partial amino acid sequencing of the mature protein. EMBO J. 1984; 3(12):2831-7.

Manthey GM, McEwen JE. The product of the nuclear gene PET309 is required for translation of mature mRNA and stability or production of intron-containing RNAs derived from the mitochondrial COXI locus of Saccharomyces cerevisiae. EMBO J. 1995; 14:403143. 
Manthey GM, Przybyla-Zawislak BD, McEwen JE. The Saccharomyces cerevisiae Pet309 protein is embedded in the mitochondrial inner membrane. Eur J Biochem. 1998; 255(1):15661.

Marathe SV, McEwen JE. Expression of the divergent transcription unit containing the yeast PET122 and OXA1 genes. Biochem Mol Biol Int. 1999; 47(6):971-7.

Martins VP, Soriani FM, Magnani T, Tudella VG, Goldman GH, Curti C, Uyemura SA. Mitochondrial function in the yeast form of the pathogenic fungus Paracoccidioides brasiliensis. J Bioenerg Biomembr. 2008; 40(4):297-305.

Mashkevich G, Repetto B, Glerum DM, Jin C, Tzagoloff A. SHY1, the yeast homolog of the ma mMalian SURF-1 gene, encodes a mitochondrial protein required for respiration. J Biol Chem. 1997; 272(22):14356-64.

Matzanke BF, Bill E, Trautwein AX, Winkelmann G. Role of siderophores in iron storage in spores of Neurospora crassa and Aspergillus ochraceus. J Bacteriol. 1987; 169(12):5873-6.

Maxfield AB, Heaton DN, Winge DR. Cox17 is functional when tethered to the mitochondrial inner membrane. J Biol Chem. 2004; 279(7):5072-80.

McEwen JG, Garcia AM, Ortiz BL, Botero S, Restrepo A.In search of the natural habitat of Paracoccidioides brasiliensis. Arch Med Res. 1995; 26(3):305-6.

McEwen JG, Bedoya V, Patiño MM, Salazar ME, Restrepo A. Experimental murine paracoccidiodomycosis induced by the inhalation of conidia. J Med Vet Mycol. 1987; 25(3):165-75.

McEwen JE, KO C, Kioeckener-Gruissem B, Poyton RO. Nuclear functions required for cytochrome c oxidase biogenesis in Saccharomyces cerevisiae. Characterization of mutants in 34 complementation groups. J Biol Chem. 1986; 261(25):11872-9.

McEwen JE, Hong KH, Park S, Preciado GT. Sequence and chromosomal localization of two PET genes required for cytochrome c oxidase assembly in Saccharomyces cerevisiae. Curr Genet. 1993; 23(1):9-14.

Medoff G, Kobayashi GS, Painter A, Travis S. Morphogenesis and pathologenecity of Histoplasma capsulatum. Infect Immun. 1987; 55(6):1355-8. 
Mei B, Budde AD, Leong SA. sid1, a gene initiating siderophore biosynthesis in Ustilago maydis: molecular characterization, regulation by iron, and role in phytopathogenicity. Proc Natl Acad Sci U S A. 1993; 90(3):903-7.

Michel H. The mechanism of proton pumping by cytochrome $c$ oxidase. Proc Natl Acad Sci USA. 1998; 27(95):12819-24.

Minczuk M, Dmochowska A, Palczewska M, Stepien PP. Overexpressed yeast mitochondrial putative RNA helicase Mss116 partially restores proper mtRNA metabolism in strains lacking the Suv3 mtRNA helicase. Yeast. 2002; 19(15):1285-93.

Montoya AE, Alvarez AL, Moreno MN, Restrepo A, McEwen JG. Eletrophoretic Karyotype of environmental isolates of Paracoccidioides brasiliensis. Med Mycol. 1999; 37:219-222.

Mulero JJ, RosenthaL JK, Fox TD. PET112, a Saccharomyces cerevisiae nuclear gene required to maintain rho+ mitochondrial DNA. Curr Genet. 1994; 25(4):299-304.

Muller PP, Fox TD. Molecular cloning and genetic mapping of the PET494 gene of Saccharomyces cerevisiae. Mol Gen Genet. 1984; 195(1-2):275-80.

Myers AM, Pape LK, Tzagoloff A. Mitochondrial protein synthesis is required for maintenance of intact mitochondrial genomes in Saccharomyces cerevisiae. EMBO J. 1985; 8:2087-92.

Naithani S, Saracco SA, Butler CA, Fox T.D. Interactions among COX1, COX2, and COX3 mRNA-specific translational activator proteins on the inner surface of the mitochondrial inner membrane of Saccharomyces cerevisiae. Mol Biol Cell. 2003; 14(1):324-33.

Neilands JB, Konopka K, Schwyn B, Coy M, Francis, RT, Paw BH, Bagg, A. Comparative biochemistry of microbial iron assimilation. In: Winkelmann G, Van der Helm D, Neilands JB, editors. Iron Transport in Microbes, Plants and Animals. New York: Weinheim, VCH; 1987. p. 3-34.

Neilands JB. Iron absorption and transport in microorganisms. Annu Rev Nutr.1981; 1:27-46. Review.

Niemer I, Schmelzer C, Borner GV. Overexpression of DEAD box protein pMSS116 promotes ATP-dependent splicing of a yeast group II intron in vitro [corrected and republished with original paging in Nucleic. Acids Res. 1995; 23(15):2966-72. 
Nino-Vega GA, Soares F, Calcagno AM, Ruiz-Herrera J, Martinez-Espinoza AD, San-Blas G. Cloning and expression analysis of the ornithine decarboxylase gene (PbrODC) of the pathogenic fungus Paracoccidioides brasiliensis. Yeast. 2004; 3:211-18.

Nobrega MP, Bandeira SCB, Beers J; Tzagoloff A. Characterization of COX19, a widely distributed gene required for expression of mitochondrial cytochrome oxidase. J Biol Chem. 2002; 277(43):40206-11.

Nobrega MP, Graminha MA, Troitskaya EN, Nobrega FG. Study of a region on yeast chromosome XIII that complements pet G199 mutants (COX7) and carries a new nonessential gene. Braz J Med Biol Res. 1998; 31(3):355-63.

Nobrega MP, Nobrega FG, Tzagoloff A. COX10 codes for a protein homologous to the ORF1 product of $P$. denitrificans and is required for the synthesis of yeast cytochrome oxidase. $\mathrm{J}$ Biol Chem. 1990; 265:14220-6.

Nunes LR, Costa de Oliveira R, Leite DB, da Silva VS, dos Reis Marques E, da Silva Ferreira ME, Ribeiro DC, de Souza Bernardes LA, Goldman MH, Puccia R, Travassos LR, Batista WL, Nobrega MP, Nobrega FG, Yang DY, de Braganca Pereira CA, Goldman GH. Transcriptome analysis of Paracoccidioides brasiliensis cells undergoing mycelium-to-yeast transition. Eukaryot Cell. 2005; 4(12):2115-28.

Oberegger H, Schoeser M, Zadra I, Abt B, Haas H. SREA is involved in regulation of siderophore biosynthesis, utilization and uptake in Aspergillus nidulans. Mol Microbiol. 2001; 41(5):1077-89.

Ohmen JD, Kloeckener-Gruissem B, McEwen JE. Molecular cloning and nucleotide sequence of the nuclear PET122 gene required for expression of the mitochondrial COX3 gene in S. cerevisiae. Nucleic Acids Res. 1988; 16(22):10783-802.

Ong DE, Emery TF. Ferrichrome biosynthesis: enzyme catalyzed formation of the hydroxamic acid group. Arch Biochem Biophys. 1972; 148(1):77-83.

Oquendo CE, Antonicka H, Shoubridge EA, Reardon W, Brown GK. Functional and genetic studies demonstrate that mutation in the COX15 gene can cause Leigh syndrome. J Med Genet. 2004; 41:540-44.

Orlando C, Pinzani P, Pazzagli M. Developments in quantitative PCR. Clin Chem Lab Med. 1998; 36:255-69.

Ott M, Prestele M, Bauerschmitt H, Funes S, Bonnefoy N, Herrmann JM. Mba1, a membrane-associated ribosome receptor in mitochondria. EMBO J. 2006; 25(8): 1603-10. 
Paret C, Ostermann K, Krause-Buchholz U, Rentzsch A, Rodel G. Human members of the SCO1 gene family: complementation analysis in yeast and intracellular localization. FEBS Lett. 1999; 447(1): 65-70.

Patterson TE, Poyton RO. COX8, the structural gene for yeast cytochrome c oxidase subunit VIII. DNA sequence and gene disruption indicate that subunit VIII is required for maximal levels of cellular respiration and is derived from a precursor which is extended at both its NH2 and COOH termini. J Biol Chem. 1986; 261(36):17192-7.

Perez-Martinez X, Broadley SA, Fox TD. Mss51p promotes mitochondrial Cox1p synthesis and interacts with newly synthesized Cox1p. EMBO J. 2003; 22(21):5951-61.

Petruzzella V, Tiranti V, Fernandez P, Ianna P, Carrozzo R, Zeviani M. Identification and characterization of human cDNAs specific to BCS1, PET112, SCO1, COX15, and COX11, five genes involved in the formation and function of the mitochondrial respiratory chain. Genomics. 1998; 54(3):494-504.

Plattner HJ, Diekmann H. Enzymology of siderophore biosynthesis in fungi. In: Winkelmann G, Winge DR, editors. Metal ions in fungi. New York: Decker; 1994. p. 99-117.

Poutre CG, Fox TD. PET111 a Saccharomyces cerevisiae nuclear gene required for translation of the mitochondrial mRNA encoding cytochrome c oxidase subunit II. Genetics. 1987; 115(4):637-47.

Power SD, Lochrie MA, Patterson TE, Poyton RO. The nuclear-coded subunits of yeast cytochrome c oxidase. II. The amino acid sequence of subunit VIII and a model for its disposition in the inner mitochondrial membrane. J Biol Chem. 1984; 259:6571-4.

Poyton RO, Schatz G. Cytochrome c oxidase from bakers' yeast. IV. Immunological evidence for the participation of a mitochondrially synthesized subunit in enzymatic activity. J Biol Chem. 1975; 250(2):762-66.

Pungartnik C, Picada J, Brendel M, Henriques JA. Further phenotypic characterization of pso mutants of Saccharomyces cerevisiae with respect to DNA repair and response to oxidative stress. Genet Mol Res. 2002; 1(1):79-89.

Pungartnik C, Kern MF, Brendel M, Henriques JA. Mutant allele pso7-1, that sensitizes Saccharomyces cerevisiae to photoactivated psoralen, is allelic with COX11, encoding a protein indispensable for a functional cytochrome c oxidase. Curr Genet. 1999; 36(3):124-9.

Reissbrodt R, Erler W, Winkelmann G. Iron supply of Pasteurella multocida and Pasteurella haemolytica. J Basic Microbiol. 1994; 34(1):61-3. 
Reinoso C, Niño-Veja G, San-Blas G, Dominguez A. Random sequencing of Paracoccidioides brasiliensis genes. Med Mycol. 2005; 43:681-9.

Reinoso C, Sorais F, Niño-Vega GA, Fermiñán E, San-Blas G, Domínguez A. Cloning and functional analysis of the orotidine-5'-phosphate decarboxylase gene (PbrURA3) of the pathogenic fungus Paracoccidioides brasiliensis. Yeast. 2005; 22(9):739-43.

Rentzsch A, Kru mMeck-Weiss G, Hofer A, Bartuschka A, Ostermann K, Rödel G. Mitochondrial copper metabolism in yeast: mutational analysis of Sco1p involved in the biogenesis of cytochrome c oxidase. Curr Genet. 1999; 35(2):103-8.

Restrepo A. The ecology of Paracoccidioides brasiliensis: a puzzle still unsolved. J Med Vet Mycol. 1985; 23:323-34.

Restrepo A, Salazar ME, Cano LE, Stover EP, Feldman D, Stevens DA. Estrogens inhibit mycelium-to-yeast transformation in the fungus Paracoccidioides brasiliensis: implications for resistance of females to paracoccidioidomycosis. Infect Immun. 1984; 46(2):346-53.

Restrepo-Moreno A. Paracoccidioidomycosis. ln: Murphy JW, Friedman H, Bendinelli M, editors. Fungallnfections and Immune Responses. New York: Plenum Press, 1993. p. 251-76.

Rho SB, Martinis SA. The bI4 group I intron binds directly to both its protein splicing partners, a tRNA synthetase and maturase, to facilitate RNA splicing activity. RNA. 2000; 6(12):1882-94.

Rodeheffer MS, Boone BE, Bryan AC, Shadel GS. Nam1p, a protein involved in RNA processing and translation, is coupled to transcription through an interaction with yeast mitochondrial RNA polymerase. J Biol Chem. 2001; 276(11): 8616-22.

Rodeheffer MS, Shadel GS. Multiple interactions involving the amino-terminal domain of yeast mtRNA polymerase determine the efficiency of mitochondrial protein synthesis. J Biol Chem. 2003; 278(20):18695-701.

Rooney PJ, Klein BS. Linking fungal morphogenesis with virulence. Cell Microbiol. 2002; 4:127-37.

Roosenberg JM 2nd, Lin YM, Lu Y, Miller MJ. Studies and syntheses of siderophores, microbial iron chelators, and analogs as potential drug delivery agents. Curr Med Chem. 2000; 7(2):159-97. 
Salazar ME, Restrepo A, Stevens DA. Inhibition by estrogens of conidium-to-yeast conversion in the fungus Paracoccidioides brasiliensis. Infect Immun. 1988; 56(3):711-13.

Samuelson JC, Chen M, Jiang F, Moller I, Wiedmann M, Kuhn A, Phillips GJ, Dalbey RE. YidC mediates membrane protein insertion in bacteria. Nature. 2000; 406(6796):637-41.

San-Blas G, Ninõ-Vega G. Paracoccidioides brasiliensis: virulence and host response In: Cihlar RL, Calderone RA, editors. Fungal pathogenesis: principles and clinical applications. New York: Marcel Dekker; 2001. p. 205-26.

Saracco SA, Fox TD. Cox18p Is Required for Export of the Mitochondrially Encoded Saccharomyces cerevisiae Cox $2 p$ C-Tail and Interacts with Pnt1p and Mss2p in the Inner Membrane. Mol Biol Cell. 2002; 13(4):1122-31.

Schwyn B, Neilands JB. Universal chemical assay for the detection and determination of siderophores. Anal Biochem. 1987; 160(1):47-56.

Schulze M, Rodel G. Accumulation of the cytochrome c oxidase subunits I and II in yeast requires a mitochondrial membrane-associated protein, encoded by the nuclear SCO1 gene. Mol Gen Genet. 1989; 216:37-43.

Schulze M, Rodel G. SCO1, a yeast nuclear gene essential for accumulation of mitochondrial cytochrome c oxidase subunit II. Mol Gen Genet. 1988; 211(3):492-8.

Seraphin B, Simon M, Faye G. MSS18, a yeast nuclear gene involved in the splicing of intron aI5 beta of the mitochondrial cox1 transcript. EMBO J. 1988; 7(5):1455-64.

Simon M, Seraphin B, Faye G. The nuclear-encoded MSS2 gene is involved in the expression of the mitochondrial cytochrome-c oxidase subunit 2 (Cox2). Biochim Biophys Acta. 1995; 1228(1):95-8.

Souza RL, Green-Willms S, Fox TD, Tzagoloff A, Nobrega FG. Cloning and characterization of COX18, a Saccharomyces cerevisiae PET gene required for the assembly of cytochrome oxidase. J Biol Chem. 2000; 275:14898-902.

Sylvestre J, Margeot A, Jacq C, Dujardin G, Corral-Debrinski M. The role of the 3' untranslated region in mRNA sorting to the vicinity of mitochondria is conserved from yeast to human cells. Mol Biol Cell. 2003; 14(9):3848-56. 
Taanman J, Capaldi RA. Purification of yeast cytochrome c oxidase with a subunit composition resembling the ma mMalian enzyme. J Biol Chem. 1992; 267:22481-5.

Taanman J, Capaldi RA. Subunit VIa of yeast cytochrome c oxidase is not necessary for assembly of the enzyme complex but modulates the enzyme activity. Isolation and characterization of the nuclear-coded gene. J Biol Chem. 1993; 268(25):18754-61.

Tay SK, Nesti C, Mancuso M, Schon EA, Shanske S, Bonilla E, Davidson MM, Dimauro S. Studies of COX16, COX19, and PET191 in human cytochrome-c oxidase deficiency. Arch Neurol. 2004; 61(12):1935-7.

Trueblood CE, Poyton RO. Differential effectiveness of yeast cytochrome c oxidase subunit genes results from differences in expression not function. Mol Cell Biol. 1987; 7(10):3520-6.

Tsukihara T, Aoyama H, Yamashita E, Tomizaki T, Yamaguchi H, Shinzawa-Itoh K, Nakashima R, Yaono R, Yoshikawa S. The whole structure of the 13-subunit oxidized cytochrome c oxidase at 2.8 A. Science. 1996; 272(5265):1136-44.

Tsukihara T, Aoyama H, Yamashita E, Tomizaki T, Yamaguchi H, Shinzawa-Itoh K, Nakashima R, Yaono R, Yoshikawa S. Structures of metal sites of oxidized bovine heart cytochrome c oxidase at 2.8 A. Science. 1995; 269(5227): 1069-74.

Tzagoloff A, Akai A, Needleman RB, Zulch G.Assembly of the mitochondrial membrane system. Cytoplasmic mutants of Saccharomyces cerevisiae with lesions in enzymes of the respiratory chain and in the mitochondrial ATPase. J Biol Chem. 1975; 250(20):8236-42.

Tzagoloff A, Nobrega M, Gorman N, Sinclair P. On the functions of the yeast COX10 and COX11 gene products. Biochem Mol Biol Int. 1993; 31(3):593-8.

Tzagoloff A. Assembly of inner membrane complexes. Ann NY Acad Sci. 1974; 227:521-6.

Tzagoloff A, Myers AM. Genetics of mitochondrial biogenesis, Ann Rev Biochem. 1986; 55:249.

Tzagoloff A, Capitanio N, Nobrega MP, Gatti D. Cytochrome oxidase assembly in yeast requires the product of COX11, a homolog of the P.denitrificans protein encoded by ORF3. EMBO J. 1990; 9:2759-64.

Tzagoloff A, Dieckmann CL. PET genes of Saccharomyces cerevisiae. Microbiol Rev. 1990; 54:211-25. 
Ueda M, Sanuki S, Kawachi H, Shimizu K, Tanaka A. Characterization of the introncontaining citrate synthase gene from the alkanotrophic yeast Candida tropicalis: cloning and expression in Saccharomyces cerevisiae. Arch Microbiol. 1997; 168:8-15.

Valencik ML, Kloeckener-Gruissem B, Poyton RO, McEwen JE. Disruption of the yeast nuclear PET54 gene blocks excision of mitochondrial intron al5 beta from pre-mRNA for cytochrome c oxidase subunit I. EMBO J. 1989; 8:3899-904.

Valnot I, Osmond S, Gigarel N, Mehaye B, Amiel J, Cormier-Daire V, Munnich A, Bonnefont JP, Rustin P, Rotig A. Mutations of the SCO1 gene in mitochondrial cytochrome c oxidase deficiency with neonatal-onset hepatic failure and encephalopathy. Am J Hum Genet. 2000; 67:1104-9.

Van der Helm D, Winkelmann G. Hydroxixamates and polycarbonates as iron transport agents (siderophore) in fungi. In: Winkelmann G, Winge DR, editors. Metal ions in fungi. New York: Decker; 1994. p. 39-148.

Waterland RA, Basu A, Chance B, Poyton RO. The isoforms of yeast cytochrome c oxidase subunit $\mathrm{V}$ alter the in vivo kinetic properties of the holoenzyme. J Biol Chem. 1991; 266(7):4180-6.

Weber T, Marahiel MA. Exploring the domain structure of modular nonribosomal peptide synthetases. Structure. 2001; 9(1):R3-9.

Weinberg ED. The role of iron in protozoan and fungal infectious diseases. J Eukaryot Microbiol. 1999; 46(3):231-8.

Wiesenberger G, Waldherr M, Schweyen RJ. The nuclear gene MRS2 is essential for the excision of group II introns from yeast mitochondrial transcripts in vivo. J Biol Chem. 1992; 267(10):6963-9.

Williams JC, Sue C, Banting GS, Yang H, Glerum DM, Hendrickson WA, Schon EA. Crystal structure of human SCO1: implications for redox signaling by a mitochondrial cytochrome c oxidase "assembly" protein. J Biol Chem. 2005; 280:15202-11.

Winkelmann G. Microbial siderophore-mediated transport. Biochem Soc Trans. 2002; 30(4):691-6.

Wright RM, Christine KO, Cumsky MG, Poyton RO. Isolation and Sequence of the Structural Gene for Cytochrome $c$ Oxidase Subunit VI from Saccharomyces cerevisiae J Biol Chem. 1984; 259(24):15401-7. 
Wright RM, Dircks LK, Poyton RO. Characterization of COX9, the nuclear gene encoding the yeast mitochondrial protein cytochrome c oxidase subunit VIIa. Subunit VIIa lacks a leader peptide and is an essential component of the holoenzyme. J Biol Chem. 1986; 261(36):1718391.

Wright RM, Rosenzweig B, Poyton RO. Organization and expression of the COX6 genetic locus in Saccharomyces cerevisiae: multiple mRNAs with different 3' termini are transcribed from COX6 and regulated differentially. Nucleic Acids Res. 1989; 17(3):103-20.

Yuan WM, Gentil GD, Budde AD, Leong SA. Characterization of the Ustilago maydis sid2 gene, encoding a multidomain peptide synthetase in the ferrichrome biosynthetic gene cluster. J Bacteriol. 2001; 183(13):4040-51.

Zsurka G, Gregan J, Schweyen RJ. The human mitochondrial Mrs2 protein functionally substitutes for its yeast homologue, a candidate magnesium transporter. Genomics. 2001; 72(2):158-68. 